\title{
Immunotoxicogenomics : gene expression profiling as a tool to study immunotoxicity
}

Citation for published version (APA):

Baken, K. A. (2007). Immunotoxicogenomics : gene expression profiling as a tool to study immunotoxicity. [Doctoral Thesis, Maastricht University]. Datawyse / Universitaire Pers Maastricht.

https://doi.org/10.26481/dis.20071115kb

Document status and date:

Published: 01/01/2007

DOI:

$10.26481 /$ dis.20071115kb

Document Version:

Publisher's PDF, also known as Version of record

\section{Please check the document version of this publication:}

- A submitted manuscript is the version of the article upon submission and before peer-review. There can be important differences between the submitted version and the official published version of record.

People interested in the research are advised to contact the author for the final version of the publication, or visit the DOI to the publisher's website.

- The final author version and the galley proof are versions of the publication after peer review.

- The final published version features the final layout of the paper including the volume, issue and page numbers.

Link to publication

\footnotetext{
General rights rights.

- You may freely distribute the URL identifying the publication in the public portal. please follow below link for the End User Agreement:

www.umlib.nl/taverne-license

Take down policy

If you believe that this document breaches copyright please contact us at:

repository@maastrichtuniversity.nl

providing details and we will investigate your claim.
}

Copyright and moral rights for the publications made accessible in the public portal are retained by the authors and/or other copyright owners and it is a condition of accessing publications that users recognise and abide by the legal requirements associated with these

- Users may download and print one copy of any publication from the public portal for the purpose of private study or research.

- You may not further distribute the material or use it for any profit-making activity or commercial gain

If the publication is distributed under the terms of Article $25 \mathrm{fa}$ of the Dutch Copyright Act, indicated by the "Taverne" license above, 


\title{
IMIUINOTOXICOCHNONICS
}

\author{
Gene expression profiling \\ as at tool to study immunotoxicity
}


(C) copyright K.A. Baken, Maastricht 2007

ISBN 978-90-5278-668-1

Universitaire Pers Maastricht

Cover design Lonneke Baken

Layout Kirsten Baken

Production Datawyse Boekproducties, Maastricht

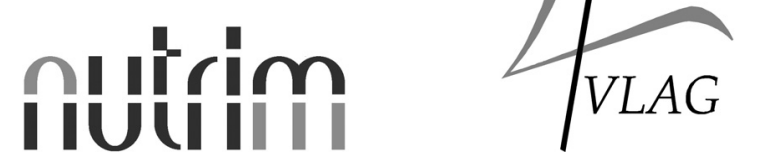

The studies presented in this thesis were performed at the Nutrition and Toxicology Research Institute Maastricht (NUTRIM), which participates in the Graduate School VLAG (Food Technology, Agrobiotechnology, Nutrition and Health Sciences), accredited by the Royal Netherlands Academy of Arts and Sciences. 


\section{IMIUSNOTOXICOOWNONICS}

\section{Gene expression profiling ats at tool to study immunutoxicity}

\section{PROEFSCHRIFT}

ter verkrijging van de graad van doctor aan de Universiteit Maastricht, op gezag van de Rector Magnificus, Prof. mr. G.P.M.F. Mols volgens het besluit van het College van Decanen, in het openbaar te verdedigen op donderdag 15 november 2007 om $16 . .^{00}$ uur

door

\section{Kirsten Annika Baken}

geboren te Eindhoven op 26 september 1980

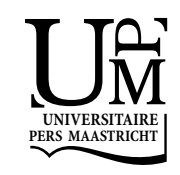




\section{Promotores}

Prof. dr. H. van Loveren

Prof. dr. J.C.S. Kleinjans

\section{Copromotor}

Dr. J.L.A. Pennings (RIVM)

\section{Beoordelingscommissie}

Prof. dr. A. Bast (voorzitter)

Prof. dr. J.W. Cohen Tervaert

Dr. R.H.H. Pieters (IRAS, Universiteit Utrecht)

Dr. H.J.M. Smeets

Prof. dr. H. van Steeg (LUMC)

Financial support for the publication of this thesis by the National Institute for Public Health and the Environment (RIVM, Bilthoven) is gratefully acknowledged. 
A simple prop to occupy my time This one goes out to the one I love

R.E.M. 



\section{Contents}

$\begin{array}{ll}\text { Abbreviations } & 9\end{array}$

Chapter 1 General introduction 13

Chapter 2 Use of the Local Lymph Node Assay in assessment of immune 45 function

Chapter 3 Gene expression profiling of bis(tri- $n$-butyltin)oxide (TBTO) induced 59 immunotoxicity in mice and rats

Chapter 4 In vitro immunotoxicity of bis(tri-n-butyltin)oxide (TBTO) studied 87 by toxicogenomics

Chapter 5 Overlapping gene expression profiles of model compounds provide 109 opportunities for immunotoxicity screening

Chapter 6 Evaluation of immunomodulation by Lactobacillus casei Shirota: immune function, autoimmunity, and gene expression

Chapter 7 Summary and general discussion

$\begin{array}{lr}\text { Samenvatting en discussie } & 169\end{array}$

$\begin{array}{ll}\text { Dankwoord } & 179\end{array}$

$\begin{array}{lc}\text { Curriculum Vitae } & 183\end{array}$

$\begin{array}{ll}\text { List of publications } & 187\end{array}$ 

Abbreviations 


\begin{tabular}{|c|c|}
\hline AhR & aryl hydrocarbon receptor \\
\hline ANOVA & analysis of variance \\
\hline $\mathrm{AOO}$ & acetone: olive oil $(4: 1)$ \\
\hline APAP & acetaminophen (paracetamol) \\
\hline APC & anaphase-promoting complex \\
\hline ATP & adenosine triphosphate \\
\hline $\mathrm{B}[\mathrm{a}] \mathrm{P}$ & benzo[a]pyrene \\
\hline Birc5 & baculoviral IAP repeat-containing 5 \\
\hline Brca1 & breast cancer 1 \\
\hline BSA & bovine serum albumin \\
\hline CAR & nuclear receptor subfamily 1 , group I, member 3 \\
\hline Ccna2 & cyclin A2 \\
\hline CDI & cumulative disease index \\
\hline Cdkn1a & cyclin-dependent kinase inhibitor 1A (p21) \\
\hline CFU & colony forming unit \\
\hline cpm & counts per minute \\
\hline CsA & cyclosporin A \\
\hline CT & cholera toxin \\
\hline $\mathrm{Ct}$ & threshold cycle \\
\hline Cy3 & Cyanine-3 \\
\hline Cy5 & Cyanine-5 \\
\hline Cyp & cytochrome P450 enzyme \\
\hline DC & dendritic cell \\
\hline (c)DNA & (complementary) deoxyribonucleic acid \\
\hline DNBS & dinitrobenzene sulfonic acid \\
\hline DNCB & 2,4-dinitrochlorobenzene \\
\hline DNFB & dinitrofluorobenzene \\
\hline DON & deoxynivalenol \\
\hline DOTC & dioctyltinchloride \\
\hline DU & depleted uranium \\
\hline E.R. & endoplasmatic reticulum \\
\hline EAE & Experimental Autoimmune Encephalomyelitis \\
\hline EASE & Expression Analysis Systematic Explorer \\
\hline ELISA & Enzyme-Linked Immunosorbent Assay \\
\hline FACS & fluorescent activated cell sorting \\
\hline FCS & fetal calf serum \\
\hline FDR & false discovery rate \\
\hline FITC & Fluorescein \\
\hline FR & fold ratio \\
\hline $\mathrm{GC}(\mathrm{R})$ & glucocorticoid (receptor) \\
\hline GO & Gene Ontology \\
\hline $\mathrm{HCB}$ & hexachlorobenzene \\
\hline IFN-y & interferon-gamma \\
\hline $\lg$ & immunoglobulin \\
\hline IL & interleukin \\
\hline Incenp & inner centromere protein \\
\hline LAB & lactic acid bacteria \\
\hline
\end{tabular}




$\begin{array}{ll}\text { LCS } & \text { Lactobacillus casei Shirota } \\ \text { LLNA } & \text { Local Lymph Node Assay } \\ \text { LO(W)ESS } & \text { locally weighted scatterplot smoothing } \\ \text { LXR } & \text { nuclear receptor subfamily 1, group H, member 3 } \\ \text { MAPK } & \text { mitogen activated protein kinase } \\ \text { MBP } & \text { myelin basic protein } \\ \text { MHC } & \text { major histocompatibility complex } \\ \text { MLN } & \text { mesenteric lymph node } \\ \text { MTD } & \text { maximum tolerated dose } \\ \text { NA } & \text { nonanoic acid } \\ \text { NAPQI } & \text { N-acetyl-p-benzoquinone imine } \\ \text { NFAT } & \text { Nuclear Factor of Activated T cells } \\ \text { Nf-kb1 } & \text { nuclear factor of kappa light chain gene enhancer in B-cells 1 } \\ \text { Nr4a1 } & \text { nuclear receptor subfamily 4, group A, member 1 } \\ \text { NK } & \text { natural killer cell } \\ \text { NTC } & \text { no treshold control } \\ \text { Nur77 } & \text { Nr4a1 } \\ \text { OD } & \text { optical density } \\ \text { OXA } & \text { oxazolone } \\ \text { PAH } & \text { polycyclic aromatic hydrocarbon } \\ \text { PBMC } & \text { peripheral blood mononuclear cell } \\ \text { PBS } & \text { phosphate buffered saline } \\ \text { PCA } & \text { principal component analysis } \\ \text { PE } & \text { phycoerythrin } \\ \text { PI } & \text { propidium iodide } \\ \text { PMT } & \text { photo multiplier tube } \\ \text { PPARY } & \text { peroxisome proliferator-activated receptor gamma } \\ \text { ppm } & \text { parts per million } \\ \text { (a)RNA } & \text { (antisense) ribonucleic acid } \\ \text { RT-PCR } & \text { reverse transcriptase polymerase chain reaction } \\ \text { RXR } & \text { retinoid X receptor } \\ \text { SD } & \text { standard deviation } \\ \text { SDS } & \text { sodium dodecyl sulphate } \\ \text { SEM } & \text { standard error of the mean } \\ \text { SPF } & \text { specific pathogen free } \\ \text { Srebp1 } & \text { sterol regulatory element binding factor 1 } \\ \text { SSC } & \text { saline sodium citrate } \\ \text { TGF- } \beta & \text { transforming growth factor } \beta \\ \text { TBT } & \text { tributyltin } \\ \text { TBTO } & \text { bis(tri-n-butyltin)oxide } \\ \text { TCDD } & 2,3,7,8-\text { tetrachlorodibenzo-p-dioxin } \\ \text { TDI } & \text { toluene diisocyanate } \\ \text { Th } & \text { T helper } \\ \text { TNF(R) } & \text { tumor necrosis factor (receptor) } \\ \text { Treg } & \text { regulatory T cell } \\ \text { w/v } & \text { weight/volume } \\ & \end{array}$





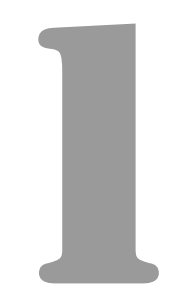

\section{General introduction}

In part published in Methods (2007) 41: 132-141 


\section{The immune system}

The function of the immune system is to protect the body from infectious microorganisms and other foreign substances. This is for a large part performed by specialized immune cells, which can be subdivided into cells involved in non-specific immunity (macrophages, granulocytes, mast cells) and lymphocytes, which are responsible for the initiation of specific immune responses. These cells originate from pluripotent hematopoietic stem cells in the bone marrow. Some of the stem cells mature into natural killer (NK) cells or differentiate into precursors that mature into B lymphocytes within the bone marrow and secondary lymphoid organs. Other precursors migrate to the thymus for proliferation and differentiation into $T$ lymphocytes. During this process, migration from the cortex to the medulla of the thymus takes place and auto-reactive $T$ cells are removed. $B$ and $T$ cells are transported to other lymphoid organs, such as the lymph nodes and the spleen, by blood and lymph. Lymph nodes (LN) occur in clusters or chains along lymphatic veins that for instance drain the ear (auricular LN) or surround the intestines (mesenteric LN). Within $\mathrm{LN}$, macrophages and lymphocytes screen the lymph that passes through the lymphatic drainage system for foreign substances. Similarly, in the spleen immune cells come into contact with and survey the blood.

When lymphocytes encounter and bind a foreign substance they become activated, proliferate, and develop into memory cells or effector cells. B cells recognize specific molecular structures (antigens) on foreign substances via immunoglobulins (Ig's) expressed at the cell surface. Ig's are also secreted into body fluids and are then referred to as antibodies, which contribute to humoral immunity. T cells and macrophages are the primary cell types involved in cell-mediated immunity. T cells recognize antigens through $T$ cell receptors after they have been processed by for instance macrophages, dendritic cells (DC), or B cells and are presented on the surface of those cells via major histocompatibility complex (MHC) molecules. They additionally associate with costimulatory regions on the surface of the antigen presenting cells. Two types of effector $T$ cells can subsequently be formed: cytotoxic $T$ cells and helper $T$ (Th) cells. Th cells promote proliferation and maturation of B cells and cytotoxic $T$ cells, either via direct cell contact or through release of soluble mediators (e.g. cytokines). In general, two subtypes are recognized based on the cytokines that are produced: Th1 cells release for example interleukin (IL)-2 and interferon (IFN)- $\mathrm{Y}$ and are predominantly involved in cell-mediated immune responses towards infectious agents, whereas Th2 cells produce IL-4 and IL-5 and mainly enhance Ig responses mediating allergic conditions. Regulatory $\mathrm{T}$ cells (Treg) can inhibit both Th1 and Th2 responsiveness [1].

\section{Immunotoxicology}

Immunotoxicology studies adverse effects of interactions of substances with the immune system. Due to its dynamic nature and the numerous interactions between its constituents, the immune system is particularly vulnerable to the impact of for instance hormones, ultraviolet radiation, bacterial products, heavy metals, and natural or chemical compounds. Immunotoxic effects include immune reactions directed towards chemicals (hypersensitivity) or towards determinants of the host that are altered by xenobiotics 
(autoimmunity) that are damaging to the host. Alternatively, toxicants may exert direct toxic effects on components of the immune system, resulting in impaired immune function (immunosuppression, which in turn may cause decreased resistance to infection or development of certain forms of neoplasia) or exaggerated immune responses (adverse immunostimulation) [1]. Numerous experimental methods are available to detect and study immunomodulatory effects, most of which make use of rodent models and assays. Changes in weight and morphology of lymphoid organs can indicate immunotoxic events. Histopathological evaluation of lymphoid tissues may for instance reveal exposure-induced lymphocyte proliferation or depletion, which can also be demonstrated by cell counting. Flow cytometry yields additional information on for instance effects on specific subpopulations of immune cells. Functional effects can be assessed in several assays using specific stimuli to elicit immune responses, such as sensitization to T cell-dependent antigens and hypersensitivity testing or serum antibody detection, proliferative responses in auricular LN to dermal application of contact sensitizers in the Local Lymph Node Assay (LLNA), host resistance to infectious microorganisms, cell proliferation and antibody or cytokine release after in vitro lymphocyte stimulation by antigens or mitogens, phagocytosis of bacteria by macrophages, lysis of lymphoma cells by NK cells, and autoimmune models of adjuvant arthritis or Experimental Autoimmune Encephalomyelitis (EAE) [1-3]. A selection of organs and techniques that are of importance for assessment of immunotoxicity and of relevance for the research described in this thesis are shown in Box I.

\section{BOX I - ASSESSMENT OF IMMUNOTOXICITY}

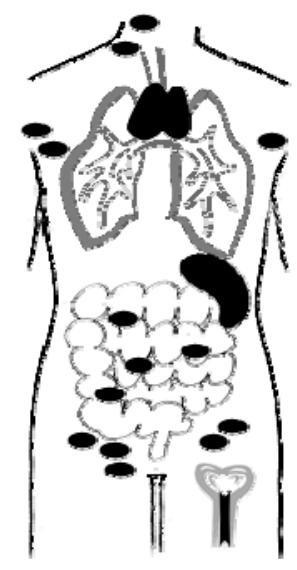

Organs:

\section{Bone marrow (formation of precursor lymphoid cells) \\ Thymus (maturation and selection of $\mathrm{T}$ lymphocytes) \\ Spleen (screening of blood by immune cells) \\ Lymph nodes (screening of lymph by immune cells)}

Techniques:

- Determination of lymphoid organ weights

- Histopathological evaluation of lymphoid organs and tissues

- Measurement of mitogen-induced lymphocyte proliferation

- Measurement of production and release of cytokines

- Modulation of sensitization in an adapted Local Lymph Node Assay 


\section{Toxicogenomics}

Microarray technology allows quantitative measurement of transcriptional activity of thousands of genes at the same time [4]. The technique is nowadays widely employed in research on cell biology, pathology, pharmacology, and toxicology and extends the scale and depth of understanding of biological processes. Toxicogenomics is the term used for identification of specific gene expression profiles in biological systems associated with xenobiotic exposure [5]. An overview of the main steps involved is presented in Box II. Assuming that the expression pattern of a gene product and its function are tightly correlated, gene expression profiling may provide insight into the underlying mechanisms of action of toxicants [6]. Since exposures leading to the same endpoint will presumably share comparable changes in gene expression, gene expression profiling might at the same time aid in characterization of classes of compounds and identification of biomarkers to be used for prediction of specific toxic effects [7-10]. This idea is supported by several proof-of-principle studies with well-characterized chemicals [8,11-19]. Immunotoxicity was, however, not addressed in those studies. Studying gene expression changes associated with immunotoxic processes, which can be referred to as 'immunotoxicogenomics', is a relatively new approach in the field of immunotoxicology. Examples of the application of toxicogenomics in immunotoxicological research are highlighted and discussed below. First, some technical aspects of the microarray analysis procedure, the establishment of public databases, and the value of toxicogenomics for risk assessment are addressed.

\section{Microarray analysis}

The basic principle of microarray technology is the hybridization between nucleic acids, one of which is immobilized on a solid matrix [20]. This is the same for different platforms, platforms meaning types of arrays or manufacturers of arrays. Per gene, a single probe or a few different probes are generated, using either PCR-amplified complementary DNA (cDNA) or synthetic DNA segments (oligonucleotides or oligos) devised on the basis of these cDNA sequences. Oligos are computer-designed in such a way that they have a similar hybridization optimum and lack significant cross-hybridization, these being significant advantages over cDNAs. In addition, oligos require fewer production steps and these steps can easily be automated, making oligos less prone to sequence errors. Hence, oligos are currently the platform of choice especially for large arrays. Some companies manufacture oligos in situ, either using photolithography (Affymetrix) or chemical coupling (Agilent). Oligos and cDNAs are spotted onto a glass surface in a regular array, a process requiring dedicated machinery. Several options exist to obtain arrays: (a) ready-made arrays (e.g. Affymetrix, Agilent, Amersham, ABI, and many others), (b) custom-made arrays (e.g. Affymetrix, Agilent), (c) in-house spotting of a PCR-amplified clone collection (e.g. Invitrogen) or an oligo collection (e.g. Operon, Sigma), and (d) inhouse spotting of an in-house prepared PCR-amplified clone collection. Several array manufacturers also market their own suited hard- and software.

The number of genes to be analyzed is of interest. Obviously, for mechanistic studies as well as for populating databases aimed to identify patterns of toxicity or toxic compounds, the number of genes should be maximal, nowadays meaning virtually all 
genes. With statistics aiding in the process of gene selection, signatures of toxicants (such as peroxisome proliferators) or pathology (such as hepatocellular necrosis) may eventually be addressed by interrogating a small number of genes.

Prior to a microarray experiment, RNA or mRNA is isolated from cells or tissues. Since microarray analysis requires very high quality purified RNA, dedicated machinery for RNA quality control has been developed, such as the Bioanalyzer (Agilent). RNA is used for cDNA synthesis and depending on the amount of starting material this CDNA can be used in an amplification step to yield antisense RNA (aRNA or cRNA). For RNA amplification, linear amplification based on the Eberwine T7 transcription method [21] has become most common as it is less sensitive to introducing changes in proportions of different RNA transcripts between samples compared to exponential (PCR-based) amplification. Several linear amplification kits are available from e.g. Ambion. Either during or after synthesis, the cDNA, aRNA, or cRNA is labeled using biotin (Affymetrix) or a fluorescent label (spotted arrays). Since the amount of starting RNA as well as labeled nucleic acid is limited, quality control must be performed on very small sample sizes. This is enabled by equipment such as the NanoDrop spectrophotometer (NanoDrop Technologies).

Labeled nucleic acids are then hybridized to the array. The Affymetrix platform uses a single labeled sample cRNA per hybridization, whereas most spotted array platforms rely on two samples labeled with Cy3 and Cy5. Most often these are a test sample and a common reference used on all arrays. Other experimental designs (e.g. a loop design in which samples are compared to one another chain wise [22]) are not frequently used, mainly because technical failure of one or more slides hampers the accompanying analysis.

After hybridization and washing, the array is read using a scanner (with fitted laser(s)) that measures the fluorescence intensity (intensities). Scanned images are processed using image analysis software (e.g. ArrayVision, GenePix, Imagene) resulting in signal data per spot. Opinion is divided as to whether the background signal should be subtracted from the spot signal data. In our experience it is better not to do so as background subtraction adds noise to the data and results in zero or negative signal values that complicate further data processing such as log transformations.

During and after the experiment a number of controls have to be performed to assure that the results obtained are reliable. Array controls include the shape of the spots and the amount of DNA spotted (e.g. by hybridization of labeled random nonamers). General hybridization controls include a similar average staining intensity over the entire array, and the absence of stains or scratches. Also, the Cy3/Cy5 ratio is plotted against their geometric average intensity in an MA-plot [23]. This ratio should be independent on the intensity for most of the genes interrogated.

In the subsequent normalization step the data are adjusted in such a way that the signal intensities obtained are comparable for most genes across the arrays, as it is generally assumed that only a minority of genes are affected in most experiments. For two-dye arrays various locally weighted linear regression (LOWESS)-based normalization algorithms are in use to smooth out minor artifacts [24]. For Affymetrix chips many public algorithms have been developed in addition to the vendor's Microarray Suite v.5 (MAS5) statistical package. Of these public algorithms, robust multi-chip average (RMA) analysis [25] is well-known and currently regarded as most reliable. 
If replicate samples are tested, statistics can be performed. In the literature, the criteria on whether a gene can be considered affected by the experimental conditions (i.e. differentially regulated) vary between studies. However, we find that a False Discovery Rate (FDR) [26] $<0.05$ to 0.1 as well as a fold ratio (FR) of $>1.5$ to 2 between expression levels in treatment and control generally answer the aims of a study. Though in many publications merely a list of regulated genes is mentioned, often more information can be extracted from the obtained data by multivariate statistics such as cluster analysis and/or principal component analysis (PCA) [27]. This results in clusters of similarly and therefore potentially co-regulated genes, indicating possible physical or functional connections between the corresponding gene products. Public algorithms to perform such analyses are available for the R statistical package (http://www.r-project.org). Commercial software packages sometimes have the advantage of easier data handling, as a command-based interface may be hard to run for less experienced users.

For a useful interpretation of microarray data, perhaps most important of all is to link the results to biological phenomena. A general method is to look for pathway or function enrichment when a (sub)set of regulated genes is compared to the entire array. Such analyses based on the Gene Ontology annotation (http://www.geneontology.org) can be performed by several web-based tools, e.g. Expression Analysis Systematic Explorer (EASE, http://david.abcc.ncifcrf.gov/ease/ease.jsp) or GoStat (http://gostat.wehi.edu.au/). This type of analysis is obviously restricted by the deficiencies in annotations that exist for many genes. Within a given pathway individual gene expression can be visualized by tools such as GenMAPP (http://www.genmapp.org), KEGG (http://www.genome.ad.jp/kegg/), or MetaCore (http://www.GeneGO.com). Finally, thorough knowledge of the literature in the field concerned is also indispensable for adequate interpretation.

\section{Toxicogenomics databases and standardization}

Discrimination of specific classes of toxicants on the basis of signature expression profiles is an important goal of toxicogenomics. In order to reliably classify compounds using gene expression profiles, validation of such signatures on an extensive data set is needed [28]. The potential for microarray data to be informative for chemical classification is therefore dependent on the sharing of data generated in individual gene expression profiling projects [29]. As a result, the research community needs standards for reporting and management of gene expression data.

\section{Conveying microarray data}

To facilitate compiling and comparison of data produced at different laboratories using various methodologies and bioinformatics tools for microarray and data analysis, a document was established that describes which information needs to accompany published microarray results for others to interpret and verify them [30]. These 'Minimum Information About a Microarray Experiment (MIAME)' guidelines (http://www.mged.org/ Workgroups/MIAME/miame.html), produced by the Microarray Gene Expression Database (MGED) society, have been adopted by publishers and used in public resources in the 
past years [31]. The set of guidelines is now also extended to MIAME/Tox in order to meet toxicogenomics-specific requirements (http://www.mged.org/ Workgroups/rsbi/rsbi.html).

For storage and exchange of results of microarray experiments in a standardized format, several public repositories have been created. Examples are the Gene Expression Omnibus (GEO) in the USA (http://www.ncbi.nlm.nih.gov/geo), ArrayExpress in Europe (http://www.ebi.ac.uk/arrayexpress), and the Center for Information Biology Gene Expression Database (CIBEX) in Japan (http://cibex.nig.ac.jp) [32]. Several journals now oblige authors to deposit their experimental data into such a repository when publishing microarray results [33]. Efforts are underway to link gene expression data stored in the major repositories [34]. In addition, initiatives have been started to build public toxicogenomics databases that besides gene expression data also incorporate associated information on biologic and toxicological endpoints so as to establish a complete knowledge base. This will advance further interpretation of expression patterns and understanding of biological systems. Some examples, for instance Chemical Effects in Biological Systems (CEBS) (http://cebs.niehs.nih.gov/nct/cebs) and Tox-MIAMExpress (http://www.ebi.ac.uk/tox-miamexpress), have been described by Mattes et al. [35]. ToxCast is a research program of the US Environmental Protection Agency (EPA) that evaluates chemical properties and bioactivity profiles of reference chemicals across a broad spectrum of data domains, including toxicogenomics, and integrates this information in models predicting toxicity [36].

The Reporting Structure for Biological Investigations (RSBI) working group represents several communities that aim to contribute towards the development of an international and compatible informatics platform for investigations employing multiple functional genomic technologies (http://www.mged.org/Workgroups/rsbi/rsbi.html). The working group intends to coordinate standardization initiatives to come to a unified approach for describing and reporting genomics experiments so that communication can be maximized and duplicated effort minimized [37]. One of the challenges that still exist is harmonization of diverse ontologies and vocabularies. Use of common annotation standards, as addressed by, among others, the Standards and Ontologies for Functional Genomics (SOFG) Conference (http://www.sofg.org), will facilitate deposition of data in public databases and data mining [37].

\section{Standardization of the microarray technology}

Now that functional genomics technologies begin to be broadly accepted and used, it is important that the microarray procedures itself are also standardized and that consistency across experiments and platforms is created. Concerns about validity of the technique could hamper uptake in diagnostics and industry. Therefore, variability of microarray data, validation of the technology, and production of standard materials is the focus of many initiatives [37]. The Health and Environmental Science Institute (HESI), for example, initiated an extensive collaborative research program, partly to identify sources of biological and technical variability associated with experimental protocols in toxicogenomics [38]. The results showed that gene expression patterns related to biological pathways are robust enough to allow insight into mechanisms, even across different platforms and laboratories. In a parallel effort, the Toxicogenomics Research Consortium TRC (http://www.niehs.nih.gov/dert/trc/intro.htm) evaluated technical variability 
within Science To Achieve Results (STAR) projects. Here it was concluded that identification of differentially expressed genes correlates between platforms, and that the main source of variability is interlaboratory variation [35]. Other investigations yielded similar findings $[39,40]$. Standardization of protocols and use of similar platforms as much as possible could thus reduce (interlaboratory) variation in gene expression measurements, thereby facilitating data exchange. The Measurements for Biotechnology (MfB) program (http://www.mfbprog.org.uk), however, also determined accuracy of microarray analysis and found the normalization strategy to have the largest impact on data comparability [35]. The MicroArrayQualityControl (MAQC) consortium, in which for instance the US Food and Drug Administration (FDA), EPA, National Institute for Standards and Technology, academic labs, and microarray platform providers are involved, demonstrated the impact of statistical analysis on reproducibility as well. Adequate reproducibility of gene expression profiling data across laboratories and platforms was found, but the criteria to identify differentially expressed genes had a high impact on overlap in gene lists that were produced, with those based on fold ratio's showing higher reproducibility than those generated using stringent $p$ values $[41,42]$. Kuo and co-workers also concluded that platforms correlate well especially when, in addition to overlapping probes, genes that are expressed at high levels are taken into account, which is most likely due to a higher variation in measurements close to the background noise [43].

\section{Use in risk assessment}

The construction of databases and attention for standardization are also required for risk assessment to benefit from toxicogenomics research. Microarray analysis might provide a promising avenue for improving risk assessment for several reasons. Firstly, gene expression profiling has been suggested to have the potential of reducing the amount of experimental animals and time needed for toxicological investigation of compounds compared to the established procedures for hazard identification $[8,44]$. Toxicological effects may be identified at an earlier time point than when traditional toxicity tests are used, and when similarities to classes of known toxicants are found, chemicals can be prioritized for further study [29]. Furthermore, understanding of mechanisms of toxicity could improve insight into adverse effects associated with exposure to compounds and aid in the choice of reliable biomarkers of exposure and effect $[29,45]$. Since sequence and function of genes are often very similar in various organisms and microarray analysis can be conducted directly in human cells [6], information on molecular responses to compounds generated by toxicogenomics studies can also show if signaling pathways and mechanisms of action are conserved across species. If so, uncertainty in inter-species extrapolations will be reduced. High-to-low dose and short-to-long term extrapolations are argued to benefit from the technique as well, resulting in more scientifically founded safety factors [38,44].

However, despite the progress in development and implementation of toxicogenomics, several obstacles have limited the interpretation of gene expression data and extraction of meaningful and useful information from it $[45,46]$. For example, mechanisms of action of compounds can depend on dose, timing, and duration of exposure and cell phenotype [47]. Besides, gene expression responses are dynamic and 
reversible, in contrast to other toxicological endpoints [45]. This hampers establishment of dose-response relationships and extrapolation between model systems. For accurate hazard characterization, insight into the relationship between genomics-based endpoints and known health outcomes is needed. A significant change in gene expression cannot be concluded to represent an adverse effect (or a small change to represent its absence) until results are placed in an appropriate biological context $[38,45,46]$ and the natural range of physiological variability of gene expression is known [48]. Moreover, toxicogenomics data may not cover all endpoints evaluated by animal studies [44]. For instance, microarray analysis will miss posttranslational modification of proteins by regulatory signals or interactions of compounds with other chemicals or metabolites in vivo, whereas both can also cause adverse effects [47,49]. Therefore, confidence in accuracy, sensitivity, and robustness of the method [50] and an extensive amount of interdisciplinary information are needed to advance the application of toxicogenomics in risk assessment $[28,46]$. Several initiatives have been started to deal with these issues $[37,38,44]$.

\section{BOX II - TOXICOGENOMICS PRINCIPLE}

RNA is isolated from control and toxicant exposed samples, labeled with different fluorescent dyes, and hybridized onto a microarray slide. After processing and statistics a set of differentially expressed genes is derived. Clustering and pathway analysis are applied to predict functional effects resulting from toxicant exposure.

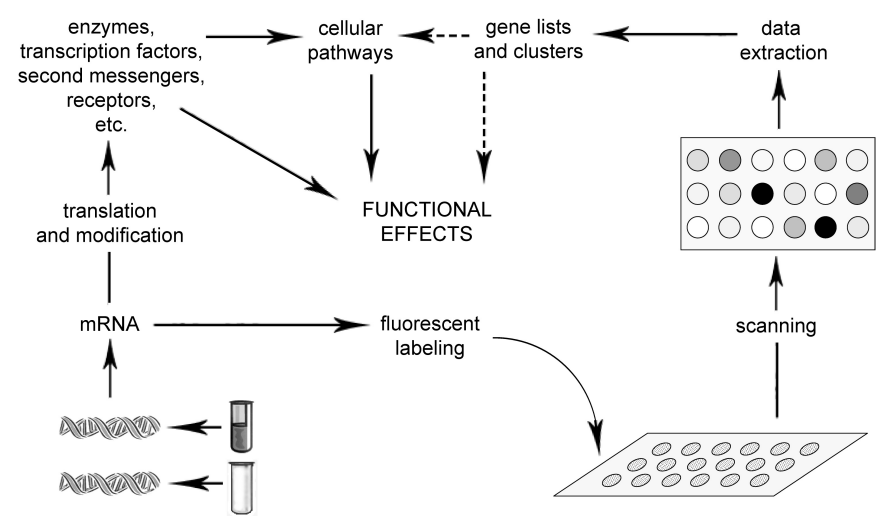




\section{Applications of microarray analysis in immunotoxicology}

Microarray technology has been employed in immunology to study molecular functions associated with immune-related genes in order to better understand immune function and regulation, also referred to as 'immunomics' [51]. Gene transcripts that are specifically expressed in immune cell subsets and participate in their maintenance and function have been identified [52,53]. Gene expression profiling is also broadening the understanding of basic and clinical immunological processes by revealing changes expression of in genes that accompany lymphocyte differentiation, activation, and signaling, self-non self recognition, regulation of innate and adaptive immunity, interindividual variations in immune response, inflammation, infection, allergic conditions, autoimmune and other immune-related diseases, and tumor antigen recognition [52,54-66]. Toxicogenomics is now increasingly applied to study alterations in gene expression after immunotoxicant exposure, but published data are still limited. Examples in the literature are discussed here.

\section{Hexachlorobenzene exposure of Brown Norway rats}

Hexachlorobenzene (HCB) is a persistent environmental pollutant with toxic effects in man and rat. Reported adverse effects include hepatic porphyria, toxic effects on the immune and reproductive system, and neurotoxicity. The Brown Norway (BN) rat strain is very susceptible to HCB-induced immunopathology. Oral exposure to HCB induces, among other things, enlargement of liver, spleen, and lymph nodes, increased serum IgM, IgG and IgE levels, and inflammatory skin and lung lesions. The mechanisms of HCB-induced immunopathology are not yet fully understood; they are very complex and involve multiple factors.

To gain more insight into the molecular mechanisms of HCB-induced toxicity, gene expression profiling was performed [67]. BN rats were exposed to a diet supplemented with 0,150 , or $450 \mathrm{mg} \mathrm{HCB}$ per $\mathrm{kg}$ food for 4 weeks. Blood, thymus, kidney, liver, spleen, and mesenteric lymph nodes (MLN) were collected. An Affymetrix array (rat genome U-34A), containing 8,799 probes identifying primarily annotated genes was used. Principal component analysis showed that effects of HCB on transcript abundance were clearly dose-related. Statistically significant $(p<0.001)$ changes in the spleen and MLN included genes associated with granulocytes, chemokines, cytokines, Ig's, and genes involved in drug metabolism and acute phase responses. Genes of which the expression was significantly changed in the liver included cytochrome P450 genes, genes involved in estrogen and porphyrin metabolism, and also genes involved in immune function. In the blood, genes encoding for instance MHC class II and T cell markers were affected. Alterations in the kidney included genes for cytokines and complement components, but also for cytochrome P450 enzymes. As expected, the thymus was only weakly affected since it is not a target organ of HCB.

Microarray analysis proved to be a suitable tool to reveal changes in gene expression that are consistent with a number of the known (immuno)toxicological effects of $\mathrm{HCB}$ in the BN rat and its induction of enzymes involved in metabolism and reproduction. Novel findings included increased gene expression of pro-inflammatory cytokines, chemokines, complement components, cell adhesion molecules, antioxidants, and acute 
phase proteins. These results are indicative for the involvement of macrophages and granulocytes and the mediators they release in the inflammatory response to HCB, which is accompanied by oxidative stress and an acute phase response. This confirms previous findings [68-70]. The study thus revealed the complexity of cells and mediators that participate in the response to $\mathrm{HCB}$ and provided more insight into the mechanisms of HCB toxicity. Measurement of gene expression at more than a single time point could, however, have yielded even more mechanistic information.

\section{Effects of 2,3,7,8-tetrachlorodibenzo-p-dioxin on gene expression}

The xenobiotic 2,3,7,8-tetrachlorodibenzo-p-dioxin (TCDD) produces a variety of toxic effects, one of the targets being the immune system. Immunotoxic effects such as induction of thymus atrophy, suppression of cytotoxic $T$ cell activity, and reduction of humoral immunity were often shown to be mediated through the aryl hydrocarbon receptor $(A h R)$ (reviewed by Inadera [71]), which is a transcription factor that can alter the expression of many genes. Zeytun et al. [72] therefore studied effects of TCDD in vivo in mice at the transcriptome level. Pathway-specific microarray analysis interrogating 83 genes involved in apoptosis, cytokine production, and angiogenesis revealed up-regulation of expression of apoptosis-related genes in the thymus and spleen and to a lesser extent the liver 1 and 3 days after TCDD administration. The results suggested that TCDDinduced apoptosis is mediated by the death receptor pathway in thymocytes. Previous observations showing that the thymus is the most sensitive target of TCDD and that TCDD can induce apoptosis in a range of cell types were thus confirmed. Besides, differential regulation of expression of genes encoding cytokines was detected in the thymus, also confirming previous observations. Cytokine expression was affected in spleen as well, but the profile differed from that in the thymus. In this study, most genes were regulated at both time points, although the expression levels varied. When additional doses of TCDD were tested, a low dose was found to induce gene expression changes already, and a small subset of genes was regulated dose-dependently [72].

In another study, gene expression changes that underlie suppression of antibody production by TCDD were investigated in lymphocytes of mice immunized with ovalbumin and adjuvant [73]. The Affymetrix Mouse Expression Array 430A was used to analyze isolated CD4 T cells and B cells. Although immunization alone mainly up-regulated gene expression, prior exposure to TCDD particularly resulted in down-regulation of gene expression in the T cells $3 \mathrm{~h}$ and especially $24 \mathrm{~h}$ after immunization, including 3 and 7 genes, respectively, that were up-regulated by immunization alone. Inhibition of antibody production by TCDD may thus be mediated by suppression of immunization-induced gene expression. Moreover, many of the suppressed genes coded for proteins that are involved in $\mathrm{G}$ protein-linked signaling in CD4 T cells, possibly activating the ERK pathway and thereby inhibiting $T$ cell activation, which is another clue to the mechanism of action of TCDD with respect to reduction of humoral immunity. In B cells, TCDD mainly upregulated gene expression, indicating that TCDD causes cell-type-specific effects [73].

Similar to the HCB study, these two experiments on TCDD-induced immunotoxicity demonstrate that microarray analysis is able to both detect known effects (even with a limited number of specific genes) and expand the knowledge on specific mechanisms of action of compounds. 


\section{Induction of gene expression changes by sensitizers}

It has been shown that oxazolone (OXA) and toluene diisocyanate (TDI) differ in their induction of IL-4, IL-10, and IFN-y in the LLNA [74]. He et al. [75] topically applied these two allergens, as well as the non-sensitizing irritant nonanoic acid (NA), on the ears of mice on 4 consecutive days, and excised the draining (auricular) LN on day 5. The resulting expression profiles were compared using Affymetrix arrays comprising 6,500 genes, and 32, 19, and 19 differentially expressed genes were found between TDI and OXA, TDI and NA, and OXA and NA, respectively. These genes included immune response-related genes and genes encoding transcription factors and signal transduction molecules, and may aid in the understanding of molecular mechanisms underlying chemical-induced hypersensitivity. The expression of selected genes was also investigated by RT-PCR. While RT-PCR was able to detect IL-4, IL-10, and IFN- $\gamma$, the microarray failed to do so. A reason for this might be the lower detection limit of RT-PCR compared to microarray analysis. In a panel of 5 other genes, only $47 \%$ concordance was observed between microarray and RT-PCR results.

Betts et al. [76] measured effects on global gene expression in the draining LN after single topical exposure to the contact allergen dinitrofluorobenzene (DNFB) on the ears of mice. Gene expression was measured at 18 and $48 \mathrm{~h}$ after application, using an Incyte array interrogating 8,734 genes. Importantly, the authors showed that the technique was both sensitive, since thresholds of detection were similar to the LLNA, and robust, since the kinetics and dose-responses could be confirmed by Northern blot and/or RTPCR. The authors described 3 genes that were significantly affected: GlyCAM-1 (downregulated), guanylate binding protein 2, an IFN- $\gamma$ inducible GTPase present in macrophages (up-regulated), and onzin (also up-regulated). The authors suggested that reduced GlyCAM-1 expression might be linked to increased LN cellularity in the absence of $L N$ cell proliferation. GlyCAM-1 is expressed by high endothelial venules (HEV), its ligand being L-selectin (CD62-L). It regulates migration of circulating lymphocytes into the periphery, and an inverse relation exists between its expression and LN weight. The authors thus hypothesized that reduced GlyCAM-1 expression is involved in recruitment of lymphocytes into the LN.

The up-regulation of guanylate-binding protein-2 and onzin expression may be in keeping with induction of Th1 responses, which is generally accepted to occur after contact allergen exposure. Guanylate-binding protein-2 is induced by the prototypical Th1 cytokine IFN-y. Onzin has $98 \%$ nucleotide sequence homology and complete amino acid sequence homology with $\mathrm{C}-15$, a cytokine or defensin, that is produced by plasmacytoid DC [77]. Plasmacytoid DC enter LN by extravasation across HEV, drive Th1 polarization in vitro by producing IL-12 and type I IFN [78], and produce CCL3, thereby recruiting Th1 cells [79]. Plasmacytoid DC were shown to be present in the inflammatory infiltrate in allergic contact dermatitis [80]. Whether DNFB exposure indeed induces plasmacytoid DC influx into the draining $L N$ remains to be established.

Ryan et al. [81] have demonstrated dose-dependent changes in gene expression in blood-derived DC induced by the contact allergen dinitrobenzene sulfonic acid (DNBS) (a water soluble analogue of dinitrochlorobenzene) that are associated with DC maturation, a process that is proposed to occur during DC migration to $\mathrm{LN}$ after activation by encountering a chemical allergen [82]. Analysis by means of Affymetrix chips (U95Av2) 
examining approximately 10,000 genes revealed up-regulation of 60 genes and downregulation of 58 genes after exposure to both doses used, representing several cellular processes such as transcription, signal transduction, protein modification and small molecule transport. A number of gene expression changes was consistent with known features of DC maturation, and some of those were reported to also occur after exposure of human DC to the contact allergen nickel sulfate [83]. Ryan et al. [81] obtained findings that were inconsistent with DC maturation as well, maybe due to differences in kinetics of the transcriptional response compared to other methods, or because the observed changes are only a portion of the changes that take place during DC maturation, or because they are chemical-specific. In this study reproducibility (among platforms and DC donors) of the observed changes was also demonstrated, as well as specificity: expression of many genes was altered only by DNBS and not by a structurally similar non-allergen. From the results of this study a list of target genes was derived that may serve to predict skin sensitization by chemicals. These genes were evaluated and further prioritized using real time RT-PCR analysis of peripheral blood mononuclear cells (PBMCs) exposed to an extended set of chemicals including irritants, contact allergens, and non-sensitizers. The 10 genes that were brought forth by this approach showed selectivity, specificity, and a proper dynamic range, and may therefore be used in screening for skin-sensitizing chemicals [84].

In conclusion, clues to mechanisms of sensitization can be inferred from the data obtained. In addition, the sensitivity, specificity, and robustness demonstrated in the different studies support the viewpoint that methods relying on microarray analysis have the potential to -at least in part- replace existing methods to uncover sensitizing effects of compounds. In general, global gene expression profiles after in vitro exposure of specific cell types to various model compounds may provide novel (sets of) biomarkers that can predict in vivo adverse effects, such as immunotoxicity. It is envisaged that ultimately small sets of biomarkers are sufficient to identify immunotoxicity, enabling high-throughput screening $[4,28]$. Since various cell types of human origin, most notably DC, can now be obtained (by culture) from human peripheral blood, a readily accessible source, the possibilities to use human cells for immunotoxicity testing have increased, making interspecies comparison superfluous. It is well imaginable, therefore, that transcript changes identified by microarray analyses such as performed by Gildea et al. [84] but also by the group of Schoeters et al. [83,85-88], can serve as new markers for allergenicity which could be used for predictive in vitro assays in the future [81].

Besides, Hansen et al. [89] were able to identify 26 differentially expressed ( $p$ $<0.01)$ genes by microarray analysis in chromium-stimulated PBMCs from allergic patients compared to healthy controls. Real time RT-PCR showed similar expression changes for three selected genes using a second allergen, nickel, in PBMCs of a nickel allergic patient. Although a larger experimental population and a higher degree of significance would be desirable, this indicates that gene expression profiling also has the potential to identify diagnostic markers for contact sensitivity. 


\section{Other examples}

Not only chemical compounds and metals but also mycotoxins can produce immunomodulatory effects. An example is the mycotoxin deoxynivalenol (DON), which was the subject of an experiment in mice [90]. Although the authors recognized limitations of the study design, such as investigation of a limited number of genes, assessment at a single time point, and the possibility of detecting a non-specific stress response, microarray analysis in spleens of mice two hours after exposure to DON or vehicle showed alterations in genes involved in immunity, inflammation, and chemotaxis that are likely to contribute to DON's immunological effects. Changes in gene expression were not highly significant $(p<0.05)$ but they were confirmed with real time RT-PCR for a selection of the genes.

As pointed out with reference to contact sensitization in the previous paragraph, microarray analysis is believed to increase the opportunities for in vitro (pre-)screening for toxicity. Besides the studies on sensitization, several other experiments on changes in gene expression induced by different compounds illustrate the potency of in vitro examination of immunotoxicity. An example is a study on JP-8 jet fuel. Inhalation or dermal exposure to JP-8 jet fuel can, among a range of other effects, impair immune function in mice [91]. JP-8 is known to induce apoptosis in several cell types. In one of these, the Jurkat cell line, gene expression of 439 stress response- and apoptosis-related genes upon exposure to JP-8 was assessed. Gene expression analysis indeed identified 16 upand 10 down-regulated genes ( $F R \geq 2$ ) associated with termination of cell proliferation or induction of apoptosis. This result may provide clues on the molecular basis of JP-8 induced cytotoxicity in immune cells [92].

In another study, the effects of various concentrations of the environmental contaminant depleted uranium (DU), a byproduct of enrichment of natural uranium, were investigated in murine peritoneal macrophages and splenic CD4+ T cells. Damage to immune cells contributes to DU's toxic effect, and DU has been shown to accumulate in macrophages and to subsequently induce apoptosis. A concentration-dependent induction of apoptosis and necrosis was detected by flow cytometry. Also, short term DU exposure of macrophages was found to influence their interaction with CD4+ cells when co-cultured resulting in enhanced $\mathrm{T}$ cell proliferation. Gene expression alterations as assessed by a cytokine gene array consisting of 514 cytokine-related cDNAs occurred in both cell types: mostly genes related to signal transduction (for instance the NF-KB signaling pathway), cytokine production (for instance up-regulation of IL-10 in macrophages), chemokines and chemokine receptors, and neurotrophic factors were affected. These effects can be linked to carcinogenesis, development of autoimmune disease, and Th2 polarization, which in part may explain observed health effects of DU exposure. As a whole, the results help to understand the mechanisms of DU-induced immune modulation [93].

The effects of a low and a high concentration of the toxic metal cadmium were investigated by Tsangaris et al. [94] in an immature T cell line at an early and late time point using cDNA microarray slides measuring 1,455 genes. Effects on the gene expression profile were time- and dose-dependent and associated with cell function, cell differentiation, malignant transformation, and cell death. Affected cell viability and apoptosis were demonstrated by other assays as well. Direct and indirect as well as early and late apoptotic effects of cadmium were detected at the transcriptome level and are in 
line with effects that were demonstrated previously in this and other immune cell lines. The gene expression alterations contribute to the knowledge on toxic and apoptotic effects of cadmium.

Cholera toxin (CT), finally, is not only responsible for the clinical symptoms of cholera but also a powerful mucosal adjuvant. The latter effect is partly caused by enhancement of the production of various cytokines and suppression of IL-12 expression, stimulating the development of Th2 cells. In order to better understand the mechanisms of action of CT, the transcriptional responses in cultured human lymphocytes and monocytes were studied. Using cDNA microarrays expression of 800 selected genes was examined after varying concentrations and time periods. Expression of more than 200 genes changed time- and dose-dependently. Particularly genes associated with immunomodulation, inflammation, and oxidative stress responded to CT. As expected, expression of Th1 markers was down-regulated whereas Th2 markers were up-regulated. Many genes affected by CT were regulated through the NF-KB pathway. The gene expression profiles were compared with those induced by an activator and an inhibitor of adenylate cyclase, since this enzyme is activated by CT resulting in intracellular cAMP accumulation. Overlap and differences of gene expression alterations induced by these three compounds yielded insight into the involvement of CAMP in CT toxicity [95]. Furthermore, in a second microarray experiment effects of CT on expression of additional genes involved in immune responses were analyzed. Expression of proinflammatory genes such as IL-8, IL-1 $1 \beta$, IL-6, and VEGF was found to be affected the most, which corresponds to earlier findings. Since the proteins encoded by the regulated genes are known to mediate the recruitment, migration, activation, proliferation, and development of lymphocytes, they are likely to contribute to the adjuvanticity of CT [96].

\section{BOX III - EXAMPLES OF IMMUNOMODULATORS STUDIED BY MICROARRAY ANALYSIS}

Immunomodulating chemicals

Hexachlorobenzene (HCB)

2,3,7,8-tetrachlorodibenzo-p-dioxin (TCDD)

JP-8 jet fuel

Bis(tri-n-butyltin)oxide (TBTO)

Benzo[a]pyrene (B[a]P)

Acetaminophen (APAP)

Non-chemical immunomodulators

Deoxynivalenol (DON)

Depleted uranium (DU)

Cadmium

Cholera toxin (CT)

Cyclosporin A (CsA)

\section{Sensitizers}

Oxazolone (OXA)

Toluene diisocyanate (TDI)

Dinitrofluorobenzene (DNFB)

Dinitrobenzene sulfonic acid (DNBS)

Chromium

Nickel 


\section{Considerations for experimental setup}

The previous paragraphs describe examples of toxicogenomics in immunotoxicological research. In general, the in vivo and in vitro experiments illustrate the potential of microarrays to confirm known molecular effects of the compounds studied as well as to be of help in elucidating their mechanisms of action.

Some issues should however be considered. In the HCB exposure study 6 organs were analyzed at three doses including vehicle control, providing a rather complete picture of the exposure effects in a 28-day study. The inclusion of organs other than immunological ones is very informative, since genes expressed outside of the immune system can still have a function in the immune response [52]. In addition, HCB is known to exert toxic effects on systems other than the immune system.

The use of a low and a high dose of HCB was especially valuable since many xenobiotics are studied at levels of significant toxicity, whereas insight into gene expression changes in the absence of pathological or cellular change may be more meaningful. For example, at higher doses cellular influx can occur, as was seen after exposure to the high dose of $\mathrm{HCB}$, causing secondary effects on gene expression. This can obscure the interpretation of microarray experiments since it may by itself cause altered abundance of certain mRNAs. Pathology may identify which cell types have entered a certain organ, while hematology can measure the changes in blood cell numbers. Genes that are expressed only or predominantly by the various blood cell types can also be used to characterize the nature and amount of cellular influx. These genes (e.g. CD markers) may or may not be included in further analysis. Certain genes will not be expressed by blood cells, regulation of them thus suggesting other processes to occur besides cell influx, while for other genes the expression by blood cells may not be known.

To evaluate the possible benefits of microarray analysis for immunotoxicology in general on the basis of the examples mentioned, it is important to stress that several studies are limited in their size. Dose- and time-dependency of gene expression effects were found in all studies including more than a single dose and time point, indicating that this is an important aspect to be considered when designing microarray experiments. An in-depth investigation on the immune response to chemical allergens, for instance, requires several doses, time points, and compounds to be tested. Additional experience with a wider range of allergens and non-allergens is also required to determine selectivity of markers to be used in screening for contact allergy, thereby improving hazard identification. Another variable, the number and timing of allergen applications, adds extra variability, further increasing the number of experiments needed.

Another drawback of some microarray studies is the limited number of genes that are investigated, such as in the studies investigating effects of TCDD, DON, JP-8 jet fuel, and DU. Interrogating a broader range of genes will yield a more general view on effects on gene expression and give insight into involvement of additional cellular pathways.

As pointed out before, for correct interpretation of gene expression data it is important to link the observed changes to other adverse effects, and to confirm results by measuring the same endpoints in different assays. This was for instance done in the studies on DNFB and cadmium. In the CT study another approach was chosen to confirm mechanisms involved, being comparison of the gene expression profile with that of compounds with the same or different mechanisms of action. In the same way, 
transcriptome changes after DNBS exposure were related to those of a structurally similar non-allergen. It is equally important to establish correlation of absence of changes in gene expression with functional effects, since effects may only be observable in specific experimental settings or at other cellular components than the transcriptome. Results of in vitro approaches should most ideally be confirmed with in vivo effects, since functional differences may exist between cells in culture or in vivo, and in vitro designs lack interaction of various biological entities [7]. This is for instance illustrated by a study comparing effects of TCDD on gene expression in vivo and in vitro [97], that did not detect immunotoxic effects in vitro whereas these were found in vivo [72,73]. Use of human cells, as was done in the studies concerning DNBS, CT, and nickel and chromium, is useful to gain insight into human relevance.

\section{Objectives and outline of the thesis}

The examples described above show the ability of microarray analysis to detect immunotoxic effects of a wide range of agents and to expand the understanding of their mechanisms of action (Box III). In order to investigate whether gene expression profiling would demonstrate and even elucidate effects of a set of immunomodulating model compounds and to examine the applicability of microarray analysis for screening of compounds for immunosuppressive effects, we performed a series of experiments in lymphoid organs and cells of mice and rats. The setup of these experiments is summarized in Box IV. Several immunomodulating agents were used, and for each of them effects on certain aspects of immune function and on gene transcription were assessed. The properties of the agents are described in more detail first, after which the outline of the thesis is explained.

\section{Immunomodulators}

Three of the compounds we have tested are well known immunosuppressants. Bis(tri- $n$ butyltin)oxide (TBTO) is an organotin compound that has been used as a biocide extensively, for instance in anti-fouling paints, and occurs as an environmental pollutant [98]. Although the production and use of TBTO is now restricted, environmental pollution persists due to slow degradation and tributyltin (TBT) compounds are still detected in the food chain [99-101]. Humans are exposed to TBT mainly through consumption of contaminated sea food [102-104]. The first adverse effect of TBTO detected was endocrine disruption resulting in masculinization in female aquatic invertebrates (imposex) [105]. Immunotoxicity is the most sensitive toxicological endpoint of TBTO in rodents. Most apparent is the direct toxicity towards cortical thymocytes resulting in thymus involution and peripheral lymphocyte depletion [98,106-113]. The consequential diminished cellular immune response manifests itself in reduced delayed type hypersensitivity response, resistance to infections, and antibody response [112,114]. TBTO also affects non-specific immune functions like NK cell and macrophage activity [115-118]. Furthermore, Th2 polarization has been described to be provoked by TBT $[119,120]$. Many cellular effects of TBT that have been revealed by studies in several species, organ systems, and cell types may mediate the toxicity of TBT compounds [105,121,122]. Some of the mechanisms of 
action proposed are perturbation of plasma membranes and membrane bound transporters, disruption of ion fluxes, and altered $\mathrm{pH}$ and ion concentrations in the cytoplasm [121,123-125]. Other effects of TBT are mitochondrial damage, disturbance of energy metabolism, and production of reactive oxygen species [124,126-129]. Furthermore, DNA, RNA, and protein synthesis have been reported to be inhibited by TBT $[130,131]$. TBT-induced thymus atrophy is most likely explained by inhibition of cell proliferation and induction of apoptosis in thymocytes. Inhibition of lymphocyte proliferation by TBT has been observed in vivo and in vitro [110,112,132-134]. Induction of apoptosis by has been ascribed to a rise in the intracellular calcium concentration, possibly mediating release of cytochrome $c$ and activation of caspases [126,127,135-150]. The latter effect has been suggested to cause cytoskeletal disruption [151,152] and calcium may activate protein kinases and phosphatases and phospholipases [141,153]. In spite of many clues to the mechanisms of action, however, the critical molecular target of TBTO remains unknown.

Cyclosporin A (CsA) is another known immunosuppressant. This fungal product is used as an immunosuppressive drug to reduce the risk of organ rejection after clinical transplantation and in the treatment of autoimmune and inflammatory diseases. CsA binds to the cytosolic protein cyclophilin, after which the complex binds and thereby inhibits calcineurin. This in turn prevents cellular translocation of the transcription factor Nuclear Factor of Activated T cells (NFAT), thereby blocking its effects. Production of cytokines such as IL-2, which is critical for $\mathrm{T}$ cell proliferation, growth factors, signaling molecules, and transcription factors is modulated by CsA [154,155]. Immunotoxic effects of CsA include histopathological changes in the thymus, spleen, and lymph nodes, altered lymphocyte subpopulations in the spleen, and interrupted $\mathrm{T}$ cell function and antibody responses [156,157].

Benzo[a]pyrene $(\mathrm{B}[\mathrm{a}] \mathrm{P})$, finally, is formed in incomplete combustion and belongs to the group of carcinogenic Polycyclic Aromatic Hydrocarbons (PAHs). Effects of this pollutant or its reactive metabolites on the immune system may be mediated by the aryl hydrocarbon receptor (AhR), disruption of cell membranes, production of various interleukins, or alteration of intracellular calcium mobilization [158]. Consequences of $\mathrm{B}[\mathrm{a}] \mathrm{P}$ exposure for the immune system include atrophy of the bone marrow, thymus, and spleen, and a reduction of circulating red and white blood cells and immunoglobulins [159].

In addition to the three immunotoxic model compounds, acetaminophen (APAP) was investigated. APAP is a common analgesic and antipyretic drug which performs its actions by inhibiting cyclooxygenase enzymes, thereby blocking prostaglandin production, and by indirect activation of cannabinoid $\mathrm{CB}(1)$ receptors [160]. At low dose levels, only a small portion of APAP is metabolized to its reactive metabolite $N$-acetyl-p-benzoquinone imine (NAPQI), which is detoxified by conjugation with glutathione. At high dose levels, however, large amounts of NAPQI are formed, resulting in glutathione depletion, protein binding, oxidative stress, mitochondrial dysfunction, and inflammatory processes, all of which mediate hepatotoxicity $[161,162]$. Due to its well characterized toxic effects on the liver, APAP has been used as a prototype hepatotoxicant in many toxicogenomics studies in recent years [163-173]. The transcriptional effects of APAP in those studies were mainly related to cell signaling, oxidative stress, the cytoskeleton and extracellular matrix, inflammation, mitochondrial malfunction, and glucose and lipid metabolism. Besides hepatotoxic effects, a few indications of immunomodulating properties of APAP have 
appeared in the literature. For example, APAP use has been associated with an increased sensitivity to or duration of infection $[174,175]$. In a double-blind, placebo-controlled trial, APAP was found to suppress specific antibody response and aggravate symptoms of rhinovirus infection at therapeutic dose levels [176]. In animal experiments focused at immunomodulation by APAP, a reduced $\mathrm{T}$ cell-dependent antibody production, delayed type hypersensitivity response, and mixed lymphocyte reaction were detected after a single hepatotoxic dose of APAP. Furthermore, the proliferative response of splenocytes and thymocytes to mitogens were found to be inhibited by APAP $[177,178]$. These immunosuppressive effects were suggested to prevent allergic or autoimmune responses to protein adducts formed by APAP's reactive metabolite.

Another immunomodulating agent that was examined is Lactobacillus casei Shirota (LCS), a probiotic bacterium of which several effects on immune function have been reported. Since the intestinal microbiota has been shown to influence the immune system, both at the intestinal and the systemic level, it is suggested that consumption of probiotic bacteria could regulate immune responses, which is one of the ways in which these bacteria may promote health (hence the name 'probiotic') [179-181]. Probiotics have indeed been found to affect the immune response in tissues other than the intestines [182185]. Lactic acid bacteria (LAB) are part of the human commensal microbiota and have a long history of use in food products. These bacteria have gained a lot of interest due to demonstration of their ability to modulate innate and acquired immune responses and their beneficial effects on intestinal infections, inflammation, and allergic and autoimmune disorders [179,184,186-192]. A large amount of studies has been performed in recent years to elucidate the mechanisms involved. A shift of the Th1/Th2 balance towards Th1mediated immunity has often been suggested to mediate immunoregulatory effects of LAB [193-198]. LCS is a nonpathogenic LAB strain from human origin which has been shown to stimulate innate and Th1-mediated immunity and to reduce allergic reactions, but suppression of autoimmunity was reported as well for LcS and for other LAB [199-215]. The way in which probiotics interact with cellular and molecular components of the immune system is not fully understood and is subject of current research. Triggering of signaling cascades, either directly or by regulating release of soluble factors, binding to toll-like receptors, and effects on DC and Treg cells are likely to be involved in the mechanism of action of LcS and other probiotics $[210,216]$. 


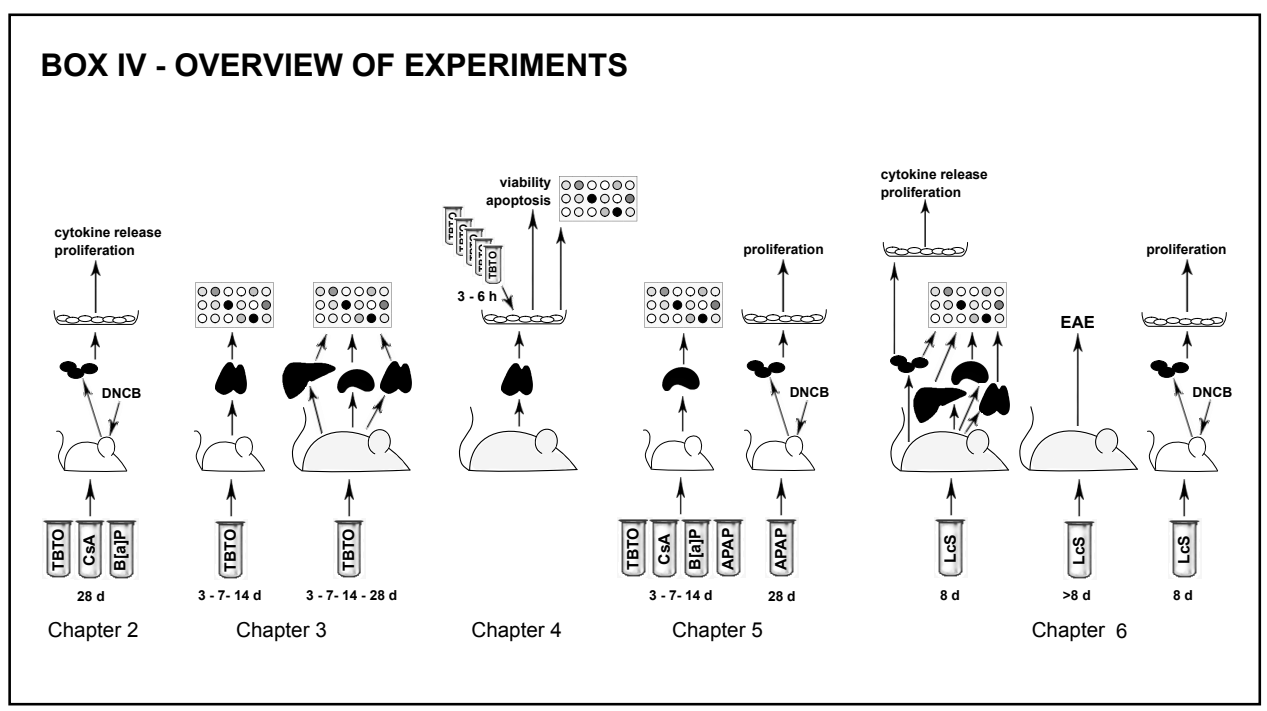

\section{Outline of the thesis}

In order to determine the capability of microarray analysis to identify immunomodulating effects of compounds, a range of agents with different modes of action and effects were analyzed. TBTO, CsA, and B[a]P are immunosuppressive compounds and they were used in several studies performed in C57BL/6 mice. Little research aimed at determining transcriptional effects of immunosuppressive agents has been published so far, and thus the potency of gene expression profiling for demonstrating effects of such compounds was not yet established. We therefore used a high dose level, the maximum tolerated dose, which surely induced an observable effect on immune responsiveness. The latter was assessed in an immune function assay that was adapted from the LLNA. The LLNA was originally designed to identify chemicals with sensitizing potential [217]. In short, chemicals are applied to the ears of mice after which the proliferative response of auricular lymph node cells is determined. Here, the mice were exposed to the three immunotoxicants for a period of 28 days prior to performance of an adapted LLNA using the well known contact sensitizer 2,4-dinitrochlorobenzene (DNCB), and besides cell proliferation, cytokine release was measured. The effect of the orally administered compounds on the immune response to the sensitizer was thus assessed, and this way the LLNA served as an immune function assay for examination of the degree of immunosuppression induced by our model compounds. Chapter 2 describes this application of the LLNA for determining effects of TBTO, CsA and Ba]P on immune function.

Subsequently, microarray analysis was performed for the first compound, TBTO, in its primary target organ, the thymus, so as to investigate whether known effects would be identified and new information on mechanisms of action could be obtained. The thymus is an important organ in immunotoxicity testing, since it is the part of the immune system most sensitive to xenobiotics [218,219]. Since gene expression analysis is expected to reveal effects already early after exposure, mice were exposed to TBTO for 3,7 , or 14 days. Originally, as is true for many toxic compounds, effects of TBTO have been studied 
in rats. We therefore performed a similar experiment in Wistar rats. Gene expression profiles in these animals were assessed after 3, 7, 14, and 28 days of exposure to a dose level causing thymus involution, which is a sensitive marker of immunotoxicity. Besides the thymus, spleen and liver were examined in this experiment since TBTO has been found to induce toxicity in those organs as well. The experiments addressing effects of TBTO in mouse thymus and rat thymus, spleen, and liver are the subject of Chapter 3.

A next step was the investigation of effects of TBTO on thymocytes in vitro. Chapter 4 describes gene expression profiling in primary rat thymocytes after TBTO exposure. This experimental setup allowed measurement of functional effects (being viability and apoptosis) at accurately defined dose levels and exposure periods. Furthermore, an experimental setting in which target cells are exposed to TBTO directly may more readily sense effects than an in vivo exposure situation. Moreover, in vitro testing would eventually be a desirable system for immunotoxicity screening because of the high throughput potential and reduction of experimental animal use. By comparing gene expression changes measured in this in vitro study to those detected in vivo, the predictive capacity of the in vitro model for effects occurring in vivo could be evaluated.

For evaluation of the applicability of gene expression profiling as a tool to screen compounds for immunotoxic properties, the transcriptional effects of several immunotoxicants needed to be compared and overlap in gene expression profiles to be identified. For this purpose, gene expression changes after exposure to TBTO, CsA, and $\mathrm{B}[\mathrm{a}] \mathrm{P}$ were investigated in murine spleens, which is described in Chapter $\mathbf{5}$. In the spleen, immune cells originating from different parts of the immune system are present and interact with each other. The spleen thus is representative for the immune system as a whole and moreover, it reflects effects occurring in peripheral lymphocytes. This is particularly relevant with a view to development of screening systems since these cells can relatively easily be obtained from rodents as well as humans. Because of the earlier indications of immunosuppressive effects of APAP, this compound was also included in this study. For further evaluation of APAP's immunomodulatory effects, the immune function assay adapted from the LLNA was performed for APAP as well.

The topic of Chapter 6 is a series of experiments aimed at elucidation of immunomodulating properties of LcS. Although the skewing towards Th1-mediated immunity by probiotic bacteria may reduce the risk for developing allergic disorders, it might at the same time facilitate autoimmune reactions [220,221]. Hence, it is important to profoundly study immunoregulation by probiotics. We therefore examined the effect of LcS on modulation of Th1-medated immunity by means of, again, the adapted LLNA applied as an immune function assay in mice and the EAE model for autoimmunity in rats. Knowledge on the mechanism of action of LcS is still limited, but LcS components are suggested to be phagocytosed by DC that subsequently migrate to MLN and other organs for antigen presentation to immune cells [210]. Therefore, cell proliferation and cytokine release were assessed in MLN of orally exposed Wistar rats, and gene expression analysis was performed in MLN, spleen, thymus, and liver of these rats with a view to obtaining information on effects of LcS at the transcriptome level and on its molecular mechanisms of action.

Chapter 7, finally, comprises a summary of the results and a general discussion. 


\section{References}

1. Kuper, C.F., De Heer, E., Van Loveren, H., Vos, J.G. (2002) Immune System. In: Handbook of Toxicologic Pathology Volume 2 (Haschek, W.M., Rousseaux, C.G., Wallig, M.A. Eds) 585-646. Academic Press, San Diego, USA.

2. Descotes, J., Pharm, D. (2006) Methods of evaluating immunotoxicity. Expert Opin Drug Metab Toxicol 2 , 249-259.

3. De Jong, W.H., Van Loveren, H. (2007) Screening of xenobiotics for direct immunotoxicity in an animal study. Methods 41, 3-8.

4. Pennie, W.D. (2000) Use of cDNA microarrays to probe and understand the toxicological consequences of altered gene expression. Toxicol Lett 112-113, 473-477.

5. Nuwaysir, E.F., Bittner, M., Trent, J., Barrett, J.C., Afshari, C.A. (1999) Microarrays and toxicology: the advent of toxicogenomics. Mol Carcinog 24, 153-159.

6. Brown, P.O., Botstein, D. (1999) Exploring the new world of the genome with DNA microarrays. Nat Genet 21, 33-37.

7. de Longueville, F., Bertholet, V., Remacle, J. (2004) DNA microarrays as a tool in toxicogenomics. Comb Chem High Throughput Screen 7, 207-211.

8. Steiner, G., Suter, L., Boess, F., Gasser, R., De Vera, M.C., Albertini, S., Ruepp, S. (2004) Discriminating different classes of toxicants by transcript profiling. Environ Health Perspect 112, 1236-1248.

9. Tugwood, J.D., Hollins, L.E., Cockerill, M.J. (2003) Genomics and the search for novel biomarkers in toxicology. Biomarkers 8, 79-92.

10. Waters, M.D., Fostel, J.M. (2004) Toxicogenomics and systems toxicology: aims and prospects. Nat Rev Genet 5, 936-948.

11. Bartosiewicz, M., Penn, S., Buckpitt, A. (2001) Applications of gene arrays in environmental toxicology: fingerprints of gene regulation associated with cadmium chloride, benzo(a)pyrene, and trichloroethylene. Environ Health Perspect 109, 71-74.

12. Bartosiewicz, M.J., Jenkins, D., Penn, S., Emery, J., Buckpitt, A. (2001) Unique gene expression patterns in liver and kidney associated with exposure to chemical toxicants. J Pharmacol Exp Ther 297, 895-905.

13. Bulera, S.J., Eddy, S.M., Ferguson, E., Jatkoe, T.A., Reindel, J.F., Bleavins, M.R., De La Iglesia, F.A. (2001) RNA expression in the early characterization of hepatotoxicants in Wistar rats by high-density DNA microarrays. Hepatology 33, 1239-1258.

14. Burczynski, M.E., McMillian, M., Ciervo, J., Li, L., Parker, J.B., Dunn, R.T., Hicken, S., Farr, S., Johnson, M.D. (2000) Toxicogenomics-based discrimination of toxic mechanism in HepG2 human hepatoma cells. Toxicol Sci 58, 399-415.

15. Hamadeh, H.K., Bushel, P.R., Jayadev, S., Martin, K., DiSorbo, O., Sieber, S., Bennett, L., Tennant, R., Stoll, R., Barrett, J.C., Blanchard, K., Paules, R.S., Afshari, C.A. (2002) Gene expression analysis reveals chemical-specific profiles. Toxicol Sci 67, 219-231.

16. Hamadeh, H.K., Bushel, P.R., Jayadev, S., DiSorbo, O., Bennett, L., Li, L., Tennant, R., Stoll, R., Barrett, J.C., Paules, R.S., Blanchard, K., Afshari, C.A. (2002) Prediction of compound signature using high density gene expression profiling. Toxicol Sci 67, 232-240.

17. Morgan, K.T. (2002) Gene expression analysis reveals chemical-specific profiles. Toxicol Sci 67, $155-156$.

18. Thomas, R.S., Rank, D.R., Penn, S.G., Zastrow, G.M., Hayes, K.R., Pande, K., Glover, E., Silander, T., Craven, M.W., Reddy, J.K., Jovanovich, S.B., Bradfield, C.A. (2001) Identification of toxicologically predictive gene sets using cDNA microarrays. Mol Pharmacol 60, 1189-1194.

19. Waring, J.F., Jolly, R.A., Ciurlionis, R., Lum, P.Y., Praestgaard, J.T., Morfitt, D.C., Buratto, B., Roberts, C., Schadt, E., Ulrich, R.G. (2001) Clustering of hepatotoxins based on mechanism of toxicity using gene expression profiles. Toxicol Appl Pharmacol 175, 28-42.

20. Duggan, D.J., Bittner, M., Chen, Y., Meltzer, P., Trent, J.M. (1999) Expression profiling using cDNA microarrays. Nat Genet 21, 10-14.

21. Van Gelder, R.N., von Zastrow, M.E., Yool, A., Dement, W.C., Barchas, J.D., Eberwine, J.H. (1990) Amplified RNA synthesized from limited quantities of heterogeneous cDNA. Proc Natl Acad Sci USA 87, 1663-1667.

22. Churchill, G.A. (2002) Fundamentals of experimental design for cDNA microarrays. Nat Rev Genet 32 Suppl, 490-495.

23. Dudoit, S., Yang, Y.H., Callow, M.J., Speed, T.P. (2002) Statistical methods for identifying differentially expressed genes in replicated cDNA microarray experiments. Stat Sin 12, 111-140.

24. Quackenbush, J. (2002) Microarray data normalization and transformation. Nat Genet 32 Suppl, 496-501. 
25. Irizarry, R.A., Hobbs, B., Collin, F., Beazer-Barclay, Y.D., Antonellis, K.J., Scherf, U., Speed, T.P. (2003) Exploration, normalization, and summaries of high density oligonucleotide array probe level data. Biostatistics 4, 249-264.

26. Benjamini, Y., Drai, D., Elmer, G., Kafkafi, N., Golani, I. (2001) Controlling the false discovery rate in behavior genetics research. Behav Brain Res 125, 279-284.

27. Eisen, M.B., Spellman, P.T., Brown, P.O., Botstein, D. (1998) Cluster analysis and display of genome-wide expression patterns. Proc Natl Acad Sci USA 95, 14863-14868.

28. Fielden, M.R., Kolaja, K.L. (2006) The state-of-the-art in predictive toxicogenomics. Curr Opin Drug Discov Devel 9, 84-91.

29. Hayes, K.R., Bradfield, C.A. (2005) Advances in toxicogenomics. Chem Res Toxicol 18, 403-414.

30. Brazma, A., Hingamp, P., Quackenbush, J., Sherlock, G., Spellman, P., Stoeckert, C., Aach, J., Ansorge, W., Ball, C.A., Causton, H.C., Gaasterland, T., Glenisson, P., Holstege, F.C., Kim, I.F., Markowitz, V., Matese, J.C., Parkinson, H., Robinson, A., Sarkans, U., Schulze-Kremer, S., Stewart, J., Taylor, R., Vilo, J., Vingron, M. (2001) Minimum information about a microarray experiment (MIAME)-toward standards for microarray data. Nat Genet 29, 365-371.

31. Imbeaud, S., Auffray, C. (2005) 'The 39 steps' in gene expression profiling: critical issues and proposed best practices for microarray experiments. Drug Discov Today 10, 1175-1182.

32. Lettieri, T. (2006) Recent applications of DNA microarray technology to toxicology and ecotoxicology. Environ Health Perspect 114, 4-9.

33. Ball, C.A., Brazma, A., Causton, H., Chervitz, S., Edgar, R., Hingamp, P., Matese, J.C., Parkinson, H., Quackenbush, J., Ringwald, M., Sansone, S.A., Sherlock, G., Spellman, P., Stoeckert, C., Tateno, Y., Taylor, R., White, J., Winegarden, N. (2004) Submission of microarray data to public repositories. PLoS Biol 2, E317.

34. Quackenbush, J. (2004) Data standards for 'omic' science. Nat Biotechnol 22, 613-614.

35. Mattes, W.B., Pettit, S.D., Sansone, S.A., Bushel, P.R., Waters, M.D. (2004) Database development in toxicogenomics: issues and efforts. Environ Health Perspect 112, 495-505.

36. Dix, D.J., Houck, K.A., Martin, M.T., Richard, A.M., Setzer, R.W., Kavlock, R.J. (2007) The ToxCast program for prioritizing toxicity testing of environmental chemicals. Toxicol Sci 95, 5-12.

37. Sansone, S.A., Morrison, N., Rocca-Serra, P., Fostel, J. (2004) Standardization initiatives in the (eco)toxicogenomics domain: a review. Comp Funct Genom 5, 633-641.

38. Pennie, W., Pettit, S.D., Lord, P.G. (2004) Toxicogenomics in risk assessment: an overview of an HESI collaborative research program. Environ Health Perspect 112, 417-419.

39. Irizarry, R.A., Warren, D., Spencer, F., Kim, I.F., Biswal, S., Frank, B.C., Gabrielson, E., Garcia, J.G., Geoghegan, J., Germino, G., Griffin, C., Hilmer, S.C., Hoffman, E., Jedlicka, A.E., Kawasaki, E., MartinezMurillo, F., Morsberger, L., Lee, H., Petersen, D., Quackenbush, J., Scott, A., Wilson, M., Yang, Y., Ye, S.Q., $\mathrm{Yu}, \mathrm{W}$. (2005) Multiple-laboratory comparison of microarray platforms. Nat Methods 2, 345-350.

40. Larkin, J.E., Frank, B.C., Gavras, H., Sultana, R., Quackenbush, J. (2005) Independence and reproducibility across microarray platforms. Nat Methods 2, 337-344.

41. Guo, L., Lobenhofer, E.K., Wang, C., Shippy, R., Harris, S.C., Zhang, L., Mei, N., Chen, T., Herman, D., Goodsaid, F.M., Hurban, P., Phillips, K.L., Xu, J., Deng, X., Sun, Y.A., Tong, W., Dragan, Y.P., Shi, L. (2006) Rat toxicogenomic study reveals analytical consistency across microarray platforms. Nat Biotechnol 24, 1162-1169.

42. MAQC Consortium (2006) The MicroArray Quality Control (MAQC) project shows inter- and intraplatform reproducibility of gene expression measurements. Nat Biotechnol 24, 1151-1161.

43. Kuo, W.P., Liu, F., Trimarchi, J., Punzo, C., Lombardi, M., Sarang, J., Whipple, M.E., Maysuria, M., Serikawa, K., Lee, S.Y., McCrann, D., Kang, J., Shearstone, J.R., Burke, J., Park, D.J., Wang, X., Rector, T.L., Ricciardi-Castagnoli, P., Perrin, S., Choi, S., Bumgarner, R., Kim, J.H., Short, G.F., III, Freeman, M.W., Seed, B., Jensen, R., Church, G.M., Hovig, E., Cepko, C.L., Park, P., Ohno-Machado, L., Jenssen, T.K. (2006) A sequence-oriented comparison of gene expression measurements across different hybridizationbased technologies. Nat Biotechnol 24, 832-840.

44. Oberemm, A., Onyon, L., Gundert-Remy, U. (2005) How can toxicogenomics inform risk assessment? Toxicol Appl Pharmacol 207, 592-598.

45. Boverhof, D.R., Zacharewski, T.R. (2006) Toxicogenomics in risk assessment: applications and needs. Toxicol Sci 89, 352-360.

46. Battershill, J.M. (2005) Toxicogenomics: regulatory perspective on current position. Hum Exp Toxicol 24, 3540.

47. Simmons, P.T., Portier, C.J. (2002) Toxicogenomics: the new frontier in risk analysis. Carcinogenesis 23 , 903-905.

48. Barlow, T., Battershill, J., Jeffery, B.R., Pollitt, F.D., Tahourdin, C.S. (2003) Report of a symposium on the use of genomics and proteomics in toxicology. Mutagenesis 18, 311-317. 
49. Cunningham, M.L., Bogdanffy, M.S., Zacharewski, T.R., Hines, R.N. (2003) Workshop overview: use of genomic data in risk assessment. Toxicol Sci 73, 209-215.

50. Cunningham, M.L., Bogdanffy, M.S., Zacharewski, T.R., Hines, R.N. (2003) Workshop overview: use of genomic data in risk assessment. Toxicol Sci 73, 209-215.

51. Schonbach, C. (2003) From immunogenetics to immunomics: functional prospecting of genes and transcripts. Novartis Found Symp 254, 177-188.

52. Abbas, A.R., Baldwin, D., Ma, Y., Ouyang, W., Gurney, A., Martin, F., Fong, S., Van Lookeren, C.M., Godowski, P., Williams, P.M., Chan, A.C., Clark, H.F. (2005) Immune response in silico (IRIS): immunespecific genes identified from a compendium of microarray expression data. Genes Immun 6, 319-331.

53. Hutton, J.J., Jegga, A.G., Kong, S., Gupta, A., Ebert, C., Williams, S., Katz, J.D., Aronow, B.J. (2004) Microarray and comparative genomics-based identification of genes and gene regulatory regions of the mouse immune system. BMC Genomics 5, 82-97.

54. Ortutay, C., Vihinen, M. (2007) Immunome: A reference set of genes and proteins for systems biology of the human immune system. Cell Immunol

55. Davies, N.J., Tadesse, M.G., Vannucci, M., Kikuchi, H., Trevino, V., Sarti, D., Dragoni, I., Contestabile, A., Zanders, E., Falciani, F. (2004) Making sense of molecular signatures in the immune system. Comb Chem High Throughput Screen 7, 231-238.

56. Ellisen, L.W., Palmer, R.E., Maki, R.G., Truong, V.B., Tamayo, P., Oliner, J.D., Haber, D.A. (2001) Cascades of transcriptional induction during human lymphocyte activation. Eur $\mathrm{J}$ Cell Biol 80, 321-328.

57. Glynne, R.J., Watson, S.R. (2001) The immune system and gene expression microarrays--new answers to old questions. J Pathol 195, 20-30.

58. Hamalainen, H., Zhou, H., Chou, W., Hashizume, H., Heller, R., Lahesmaa, R. (2001) Distinct gene expression profiles of human type 1 and type $2 \mathrm{~T}$ helper cells. Genome Biol 2, RESEARCH0022.1RESEARCH0022.11.

59. Hoffmann, K.F., McCarty, T.C., Segal, D.H., Chiaramonte, M., Hesse, M., Davis, E.M., Cheever, A.W., Meltzer, P.S., Morse, H.C., III, Wynn, T.A. (2001) Disease fingerprinting with cDNA microarrays reveals distinct gene expression profiles in lethal type 1 and type 2 cytokine-mediated inflammatory reactions. FASEB J 15, 2545-2547.

60. Maecker, B., von, B., Anderson, K.S., Vonderheide, R.H., Schultze, J.L. (2001) Linking genomics to immunotherapy by reverse immunology--'immunomics' in the new millennium. Curr Mol Med 1, 609-619.

61. Marrack, P., Mitchell, T., Hildeman, D., Kedl, R., Teague, T.K., Bender, J., Rees, W., Schaefer, B.C., Kappler, J. (2000) Genomic-scale analysis of gene expression in resting and activated T cells. Curr Opin Immunol 12, 206-209.

62. Saito, H., Nakajima, T., Matsumoto, K. (2001) Human mast cell transcriptome project. Int Arch Allergy Immunol 125, 1-8.

63. Schmidt-Weber, C.B., Wohlfahrt, J.G., Blaser, K. (2001) DNA arrays in allergy and immunology. Int Arch Allergy Immunol 126, 1-10.

64. Shaffer, A.L., Rosenwald, A., Hurt, E.M., Giltnane, J.M., Lam, L.T., Pickeral, O.K., Staudt, L.M. (2001) Signatures of the immune response. Immunity 15, 375-385.

65. Staudt, L.M., Brown, P.O. (2000) Genomic views of the immune system*. Annu Rev Immunol 18, 829-859.

66. Van der Pouw Kraan TC, Kasperkovitz, P.V., Verbeet, N., Verweij, C.L. (2004) Genomics in the immune system. Clin Immunol 111, 175-185.

67. Ezendam, J., Staedtler, F., Pennings, J., Vandebriel, R.J., Pieters, R., Harleman, J.H., Vos, J.G. (2004) Toxicogenomics of subchronic hexachlorobenzene exposure in Brown Norway rats. Environ Health Perspect 112, 782-791.

68. Ezendam, J., Hassing, I., Bleumink, R., Vos, J.G., Pieters, R. (2004) Hexachlorobenzene-induced Immunopathology in Brown Norway rats is partly mediated by T cells. Toxicol Sci 78, 88-95.

69. Ezendam, J., Kosterman, K., Spijkerboer, H., Bleumink, R., Hassing, I., Van Rooijen, N., Vos, J.G., Pieters, R. (2005) Macrophages are involved in hexachlorobenzene-induced adverse immune effects. Toxicol Appl Pharmacol 209, 19-27.

70. Michielsen, C.C., Van Loveren, H., Vos, J.G. (1999) The role of the immune system in hexachlorobenzeneinduced toxicity. Environ Health Perspect 107 Suppl 5, 783-792.

71. Inadera, H. (2006) The immune system as a target for environmental chemicals: Xenoestrogens and other compounds. Toxicol Lett 164, 191-206.

72. Zeytun, A., McKallip, R.J., Fisher, M., Camacho, I., Nagarkatti, M., Nagarkatti, P.S. (2002) Analysis of 2,3,7,8-tetrachlorodibenzo-p-dioxin-induced gene expression profile in vivo using pathway-specific cDNA arrays. Toxicology 178, 241-260.

73. Nagai, H., Takei, T., Tohyama, C., Kubo, M., Abe, R., Nohara, K. (2005) Search for the target genes involved in the suppression of antibody production by TCDD in C57BL/6 mice. Int Immunopharmacol 5, 331-343. 
74. Van Och, F.M., Van Loveren, H., De Jong, W.H., Vandebriel, R.J. (2002) Cytokine production induced by low-molecular-weight chemicals as a function of the stimulation index in a modified local lymph node assay: an approach to discriminate contact sensitizers from respiratory sensitizers. Toxicol Appl Pharmacol 184, 4656.

75. He, B., Munson, A.E., Meade, B.J. (2001) Analysis of gene expression induced by irritant and sensitizing chemicals using oligonucleotide arrays. Int Immunopharmacol 1, 867-879.

76. Betts, C.J., Moggs, J.G., Caddick, H.T., Cumberbatch, M., Orphanides, G., Dearman, R.J., Ryan, C.A., Hulette, B.C., Frank, G.G., Kimber, I. (2003) Assessment of glycosylation-dependent cell adhesion molecule 1 as a correlate of allergen-stimulated lymph node activation. Toxicology 185, 103-117.

77. Rissoan, M.C., Duhen, T., Bridon, J.M., Bendriss-Vermare, N., Peronne, C., De Saint Vis, B., Briere, F., Bates, E.E. (2002) Subtractive hybridization reveals the expression of immunoglobulin-like transcript 7, EphB1, granzyme B, and 3 novel transcripts in human plasmacytoid dendritic cells. Blood 100, 3295-3303.

78. Cella, M., Facchetti, F., Lanzavecchia, A., Colonna, M. (2000) Plasmacytoid dendritic cells activated by influenza virus and CD40L drive a potent TH1 polarization. Nat Immunol 1, 305-310.

79. Penna, G., Vulcano, M., Roncari, A., Facchetti, F., Sozzani, S., Adorini, L. (2002) Cutting edge: differential chemokine production by myeloid and plasmacytoid dendritic cells. J Immunol 169, 6673-6676.

80. Bangert, C., Friedl, J., Stary, G., Stingl, G., Kopp, T. (2003) Immunopathologic features of allergic contact dermatitis in humans: participation of plasmacytoid dendritic cells in the pathogenesis of the disease? $\mathrm{J}$ Invest Dermatol 121, 1409-1418.

81. Ryan, C.A., Gildea, L.A., Hulette, B.C., Dearman, R.J., Kimber, I., Gerberick, G.F. (2004) Gene expression changes in peripheral blood-derived dendritic cells following exposure to a contact allergen. Toxicol Lett 150, 301-316.

82. Pennie, W.D., Kimber, I. (2002) Toxicogenomics; transcript profiling and potential application to chemical allergy. Toxicol In vitro 16, 319-326.

83. Schoeters, E., Nuijten, J.M., Van Den Heuvel, R.L., Nelissen, I., Witters, H., Schoeters, G.E., Van Tendeloo, V.F., Berneman, Z.N., Verheyen, G.R. (2006) Gene expression signatures in CD34+-progenitor-derived dendritic cells exposed to the chemical contact allergen nickel sulfate. Toxicol Appl Pharmacol 216, 131-149.

84. Gildea, L.A., Ryan, C.A., Foertsch, L.M., Kennedy, J.M., Dearman, R.J., Kimber, I., Gerberick, G.F. (2006) Identification of Gene Expression Changes Induced by Chemical Allergens in Dendritic Cells: Opportunities for Skin Sensitization Testing. J Invest Dermatol 126, 1813-1822.

85. Schoeters, E., Verheyen, G.R., Van Den Heuvel, R., Nelissen, I., Witters, H., Van Tendeloo, V., Schoeters, G.E., Berneman, Z.N. (2005) Expression analysis of immune-related genes in CD34(+) progenitor-derived dendritic cells after exposure to the chemical contact allergen DNCB. Toxicol In vitro 19, 909-913.

86. Schoeters, E., Nuijten, J.M., Van Den Heuvel, R.L., Nelissen, I., Witters, H., Schoeters, G.E., Van Tendeloo, V., Berneman, Z.N., Verheyen, G.R. (2006) Gene expression signatures in CD34+-progenitor-derived dendritic cells exposed to the chemical contact allergen nickel sulfate. Toxicol Appl Pharmacol 216, 131-149.

87. Schoeters, E., Verheyen, G.R., Nelissen, I., Van Rompay, A.R., Hooyberghs, J., Van Den Heuvel, R.L., Witters, H., Schoeters, G.E., Van Tendeloo, V., Berneman, Z.N. (2007) Microarray analyses in dendritic cells reveal potential biomarkers for chemical-induced skin sensitization. Mol Immunol 44, 3222-3233.

88. Verheyen, G.R., Schoeters, E., Nuijten, J.M., Van Den Heuvel, R.L., Nelissen, I., Witters, H., Van Tendeloo, V., Berneman, Z.N., Schoeters, G.E. (2005) Cytokine transcript profiling in CD34+-progenitor derived dendritic cells exposed to contact allergens and irritants. Toxicol Lett 155, 187-194.

89. Hansen, M.B., Skov, L., Menne, T., Olsen, J. (2005) Gene transcripts as potential diagnostic markers for allergic contact dermatitis. Contact Dermatitis 53, 100-106.

90. Kinser, S., Jia, Q., Li, M., Laughter, A., Cornwell, P., Corton, J.C., Pestka, J. (2004) Gene expression profiling in spleens of deoxynivalenol-exposed mice: immediate early genes as primary targets. $\mathrm{J}$ Toxicol Environ Health A 67, 1423-1441.

91. Dudley, A.C., Peden-Adams, M.M., EuDaly, J., Pollenz, R.S., Keil, D.E. (2001) An aryl hydrocarbon receptor independent mechanism of JP-8 jet fuel immunotoxicity in Ah-responsive and Ah-nonresponsive mice. Toxicol Sci 59, 251-259.

92. Espinoza, L.A., Smulson, M.E. (2003) Macroarray analysis of the effects of JP-8 jet fuel on gene expression in Jurkat cells. Toxicology 189, 181-190.

93. Wan, B., Fleming, J.T., Schultz, T.W., Sayler, G.S. (2006) In vitro immune toxicity of depleted uranium: effects on murine macrophages, CD4+ T cells, and gene expression profiles. Environ Health Perspect 114, 85-91.

94. Tsangaris, G.Th., Botsonis, A., Politis, I., Tzortzatou-Stathopoulou, F. (2002) Evaluation of cadmium-induced transcriptome alterations by three color cDNA labeling microarray analysis on a T-cell line. Toxicology 178, 135-160. 
95. Royaee, A.R., Mendis, C., Das, R., Jett, M., Yang, D.C. (2006) Cholera toxin induced gene expression alterations. Mol Immunol 43, 702-709.

96. Royaee, A.R., Hammamieh, R., Mendis, C., Das, R., Jett, M., DC, H.Y. (2006) Induction of immunomodulator transcriptional responses by cholera toxin. Mol Immunol 43, 1020-1028.

97. Dere, E., Boverhof, D.R., Burgoon, L.D., Zacharewski, T.R. (2006) In vivo - in vitro toxicogenomic comparison of TCDD-elicited gene expression in Hepa1c1c7 mouse hepatoma cells and C57BL/6 hepatic tissue. BMC Genomics 7, 80-97.

98. Boyer, I.J. (1989) Toxicity of dibutyltin, tributyltin and other organotin compounds to humans and to experimental animals. Toxicology 55, 253-298.

99. Hoch, M. (2001) Organotin compounds in the environment - an overview. Appl Geochem 16, 719-743.

100. Forsyth, D.S., Casey, V. (2003) Butyltin compounds in retail mollusc products. Food Addit Contam 20, 445452.

101. Kannan, K., Tanabe, S., Tatsukawa, R. (1995) Occurrence of butyltin residues in certain foodstuffs. Bull Environ Contam Toxicol 55, 510-516.

102. Nielsen, J.B., Strand, J. (2002) Butyltin compounds in human liver. Environ Res 88, 129-133.

103. Kannan, K., Senthilkumar, K., Giesy, J.P. (1999) Occurrence of butyltin compounds in human blood. Environ Sci Technol 33, 1776-1779.

104. Takahashi, S., Mukai, H., Tanabe, S., Sakayama, K., Miyazaki, T., Masuno, H. (1999) Butyltin residues in livers of humans and wild terrestrial mammals and in plastic products. Environ Pollut 106, 213-218.

105. EFSA (2004) Opinion of the Scientific Panel on Contaminants in the Food Chain on a request from the Commission to assess the health risks to consumers associated with exposure to organotins in foodstuffs. The EFSA Journal 102, 1-119.

106. Bressa, G., Hinton, R.H., Price, S.C., Isbir, M., Ahmed, R.S., Grasso, P. (1991) Immunotoxicity of tri- $n$ butyltin oxide (TBTO) and tri-n-butyltin chloride (TBTC) in the rat. J Appl Toxicol 11, 397-402.

107. De Waal, E.J., Schuurman, H.J., Van Loveren, H., Vos, J.G. (1997) Differential effects of 2,3,7,8tetrachlorodibenzo-p-dioxin, bis(tri- $n$ - butyltin) oxide and cyclosporine on thymus histophysiology. Crit Rev Toxicol 27, 381-430.

108. Smialowicz, R.J., Riddle, M.M., Rogers, R.R., Leubke, R.W., Copeland, C.B., Ernst, G.G. (1990) Immune alterations in rats following subacute exposure to tributyltin oxide. Toxicology 64, 169-178.

109. Snoeij, N.J., Penninks, A.H., Seinen, W. (1987) Biological activity of organotin compounds--an overview. Environ Res 44, 335-353.

110. Snoeij, N.J., Penninks, A.H., Seinen, W. (1988) Dibutyltin and tributyltin compounds induce thymus atrophy in rats due to a selective action on thymic lymphoblasts. Int J Immunopharmacol 10, 891-899.

111. Verdier, F., Virat, M., Schweinfurth, H., Descotes, J. (1991) Immunotoxicity of bis(tri- $n$-butyltin) oxide in the rat. J Toxicol Environ Health 32, 307-317.

112. Vos, J.G., De Klerk, A., Krajnc, E.I., Kruizinga, W., Van Ommen, B., Rozing, J. (1984) Toxicity of bis(tri-nbutyltin)oxide in the rat. II. Suppression of thymus-dependent immune responses and of parameters of nonspecific resistance after short-term exposure. Toxicol Appl Pharmacol 75, 387-408.

113. Wester, P.W., Krajnc, E.I., Van Leeuwen, F.X., Loeber, J.G., Van der Heijden, C.A., Vaessen, H.A., Helleman, P.W. (1990) Chronic toxicity and carcinogenicity of bis(tri- $n$-butyltin)oxide (TBTO) in the rat. Food Chem Toxicol 28, 179-196.

114. Vos, J.G., De Klerk, A., Krajnc, E.I., Van Loveren, H., Rozing, J. (1990) Immunotoxicity of bis(tri- $n$ butyltin)oxide in the rat: effects on thymus-dependent immunity and on nonspecific resistance following longterm exposure in young versus aged rats. Toxicol Appl Pharmacol 105, 144-155.

115. Kergosien, D.H., Rice, C.D. (1998) Macrophage secretory function is enhanced by low doses of tributyltinoxide (TBTO), but not tributyltin-chloride (TBTCI). Arch Environ Contam Toxicol 34, 223-228.

116. Van Loveren, H., Krajnc, E.I., Rombout, P.J., Blommaert, F.A., Vos, J.G. (1990) Effects of ozone, hexachlorobenzene, and bis(tri-n-butyltin)oxide on natural killer activity in the rat lung. Toxicol Appl Pharmacol 102, 21-33.

117. Whalen, M.M., Green, S.A., Loganathan, B.G. (2002) Brief butyltin exposure induces irreversible inhibition of the cytotoxic function on human natural killer cells, in vitro. Environ Res 88, $19-29$.

118. Wilson, S., Dzon, L., Reed, A., Pruitt, M., Whalen, M.M. (2004) Effects of in vitro exposure to low levels of organotin and carbamate pesticides on human natural killer cell cytotoxic function. Environ Toxicol 19, 554563.

119. Kato, T., Uchikawa, R., Yamada, M., Arizono, N., Oikawa, S., Kawanishi, S., Nishio, A., Nakase, H., Kuribayashi, K. (2004) Environmental pollutant tributyltin promotes Th2 polarization and exacerbates airway inflammation. Eur J Immunol 34, 1312-1321. 
120. Kato, T., Tada-Oikawa, S., Takahashi, K., Saito, K., Wang, L., Nishio, A., Hakamada-Taguchi, R., Kawanishi, S., Kuribayashi, K. (2006) Endocrine disruptors that deplete glutathione levels in APC promote Th2 polarization in mice leading to the exacerbation of airway inflammation. Eur J Immunol 36, 1199-1209.

121. Fent, K. (1996) Ecotoxicology of organotin compounds. Crit Rev Toxicol 26, 1-117.

122. Inadera, H. (2006) The immune system as a target for environmental chemicals: Xenoestrogens and other compounds. Toxicol Lett 164, 191-206.

123. von Ballmoos, C., Brunner, J., Dimroth, P. (2004) The ion channel of F-ATP synthase is the target of toxic organotin compounds. Proc Natl Acad Sci U S A 101, 11239-11244.

124. Powers, M.F., Beavis, A.D. (1991) Triorganotins inhibit the mitochondrial inner membrane anion channel. J Biol Chem 266, 17250-17256.

125. Zucker, R.M., Elstein, K.H., Easterling, R.E., Ting-Beall, H.P., Allis, J.W., Massaro, E.J. (1988) Effects of tributyltin on biomembranes: alteration of flow cytometric parameters and inhibition of $\mathrm{Na}+, \mathrm{K}+-\mathrm{ATPase}$ twodimensional crystallization. Toxicol Appl Pharmacol 96, 393-403.

126. Chow, S.C., Kass, G.E., McCabe, M.J., Jr., Orrenius, S. (1992) Tributyltin increases cytosolic free Ca2+ concentration in thymocytes by mobilizing intracellular $\mathrm{Ca} 2+$, activating a $\mathrm{Ca} 2+$ entry pathway, and inhibiting Ca2+ efflux. Arch Biochem Biophys 298, 143-149.

127. Gennari, A., Viviani, B., Galli, C.L., Marinovich, M., Pieters, R., Corsini, E. (2000) Organotins induce apoptosis by disturbance of $[\mathrm{Ca}(2+)](\mathrm{i})$ and mitochondrial activity, causing oxidative stress and activation of caspases in rat thymocytes. Toxicol Appl Pharmacol 169, 185-190.

128. Corsini, E., Viviani, B., Marinovich, M., Galli, C.L. (1997) Role of mitochondria and calcium ions in tributyltininduced gene regulatory pathways. Toxicol Appl Pharmacol 145, 74-81.

129. Snoeij, N.J., Punt, P.M., Penninks, A.H., Seinen, W. (1986) Effects of tri- $n$-butyltin chloride on energy metabolism, macromolecular synthesis, precursor uptake and cyclic AMP production in isolated rat thymocytes. Biochim Biophys Acta 852, 234-243.

130. Marinovich, M., Viviani, B., Galli, C.L. (1990) Reversibility of tributyltin-chloride-induced protein synthesis inhibition after ATP recovery in HEL-30 cells. Toxicol Lett 52, 311-317.

131. Snoeij, N.J., Van Rooijen, H.J., Penninks, A.H., Seinen, W. (1986) Effects of various inhibitors of oxidative phosphorylation on energy metabolism, macromolecular synthesis and cyclic AMP production in isolated rat thymocytes. A regulating role for the cellular energy state in macromolecular synthesis and cyclic AMP production. Biochem Biophys Acta 852, 244-253.

132. Nakata, H., Sakakibara, A., Kanoh, M., Kudo, S., Watanabe, H., Nagai, N., Miyazaki, N., Asano, Y., Tanabe, S. (2002) Evaluation of mitogen-induced responses in marine mammal and human lymphocytes by in-vitro exposure of butyltins and non-ortho coplanar PCBs. Environ Pollut 120, 245-253.

133. Snoeij, N.J., Van lersel, A.A., Penninks, A.H., Seinen, W. (1986) Triorganotin-induced cytotoxicity to rat thymus, bone marrow and red blood cells as determined by several in vitro assays. Toxicology 39, 71-83.

134. Vandebriel, R.J., Spiekstra, S.W., Hudspith, B.N., Meredith, C., Van Loveren, H. (1999) In vitro exposure effects of cyclosporin $A$ and bis(tri- $n$-butyltin)oxide on lymphocyte proliferation, cytokine (receptor) mRNA expression, and cell surface marker expression in rat thymocytes and splenocytes. Toxicology 135, 49-66.

135. Ade, T., Zaucke, F., Krug, H.F. (1996) The structure of organometals determines cytotoxicity and alteration of calcium homeostasis in HL-60 cells. Anal Bioanal Chem 354, 609-614.

136. Aw, T.Y., Nicotera, P., Manzo, L., Orrenius, S. (1990) Tributyltin stimulates apoptosis in rat thymocytes. Arch Biochem Biophys 283, 46-50.

137. Chikahisa, L., Oyama, Y. (1992) Tri- $n$-butyltin increases intracellular Ca2+ in mouse thymocytes: a flowcytometric study using fluorescent dyes for membrane potential and intracellular $\mathrm{Ca} 2+$. Pharmacol Toxicol 71, 190-195.

138. Gennari, A., Potters, M., Seinen, W., Pieters, R. (1997) Organotin-induced apoptosis as observed in vitro is not relevant for induction of thymus atrophy at antiproliferative doses. Toxicol Appl Pharmacol 147, 259-266.

139. Gennari, A., Bleumink, R., Viviani, B., Galli, C.L., Marinovich, M., Pieters, R., Corsini, E. (2002) Identification by DNA macroarray of nur77 as a gene induced by di-n-butyltin dichloride: its role in organotin-induced apoptosis. Toxicol Appl Pharmacol 181, 27-31.

140. Gogvadze, V., Stridh, H., Orrenius, S., Cotgreave, I. (2002) Tributyltin causes cytochrome C release from isolated mitochondria by two discrete mechanisms. Biochem Biophys Res Commun 292, 904-908.

141. Grundler, W., Dirscherl, P., Beisker, W., Marx, K., Stampfl, A., Maier, K., Zimmermann, I., Nusse, M. (2001) Early functional apoptotic responses of thymocytes induced by Tri- $n$-butyltin. Cytometry 44, 45-56.

142. Kawanishi, T., Kiuchi, T., Asoh, H., Shibayama, R., Kawai, H., Ohata, H., Momose, K., Hayakawa, T. (2001) Effect of tributyltin chloride on the release of calcium ion from intracellular calcium stores in rat hepatocytes. Biochem Pharmacol 62, 863-872.

143. Oyama, Y., Ueha, T., Hayashi, A., Chikahisa, L. (1994) Effect of tri-n-butyltin on intracellular Ca2+ concentration of mouse thymocytes under $\mathrm{Ca}(2+)$-free condition. Eur J Pharmacol 270, 137-142. 
144. Pieters, R.H., Bol, M., Penninks, A.H. (1994) Immunotoxic organotins as possible model compounds in studying apoptosis and thymocyte differentiation. Toxicology 91, 189-202.

145. Raffray, M., Cohen, G.M. (1991) Bis(tri- $n$-butyltin)oxide induces programmed cell death (apoptosis) in immature rat thymocytes. Arch Toxicol 65, 135-139.

146. Raffray, M., Cohen, G.M. (1993) Thymocyte apoptosis as a mechanism for tributyltin-induced thymic atrophy in vivo. Arch Toxicol 67, 231-236.

147. Raffray, M., McCarthy, D., Snowden, R.T., Cohen, G.M. (1993) Apoptosis as a mechanism of tributyltin cytotoxicity to thymocytes: relationship of apoptotic markers to biochemical and cellular effects. Toxicol Appl Pharmacol 119, 122-130.

148. Reader, S., Moutardier, V., Denizeau, F. (1999) Tributyltin triggers apoptosis in trout hepatocytes: the role of $\mathrm{Ca} 2+$, protein kinase $\mathrm{C}$ and proteases. Biochim Biophys Acta 1448, 473-485.

149. Stridh, H., Kimland, M., Jones, D.P., Orrenius, S., Hampton, M.B. (1998) Cytochrome c release and caspase activation in hydrogen peroxide- and tributyltin-induced apoptosis. FEBS Lett 429, 351-355.

150. Stridh, H., Cotgreave, I., Muller, M., Orrenius, S., Gigliotti, D. (2001) Organotin-induced caspase activation and apoptosis in human peripheral blood lymphocytes. Chem Res Toxicol 14, 791-798.

151. Chow, S.C., Orrenius, S. (1994) Rapid cytoskeleton modification in thymocytes induced by the immunotoxicant tributyltin. Toxicol Appl Pharmacol 127, 19-26.

152. Lavastre, V., Girard, D. (2002) Tributyltin induces human neutrophil apoptosis and selective degradation of cytoskeletal proteins by caspases. J Toxicol Environ Health A 65, 1013-1024.

153. Kafer, A., Krug, H.F. (1994) Effects of organometals on cellular signaling. I. Influence of metabolic inhibitors on metal-induced arachidonic acid liberation. Environ Health Perspect 102 Suppl 3, 325-330.

154. Hamawy, M.M. (2003) Molecular actions of calcineurin inhibitors. Drug News Perspect 16, 277-282.

155. Kiani, A., Rao, A., Aramburu, J. (2000) Manipulating immune responses with immunosuppressive agents that target NFAT. Immunity 12, 359-372.

156. De Waal, E.J., Timmerman, H.H., Dortant, P.M., Kranjc, M.A., Van Loveren, H. (1995) Investigation of a screening battery for immunotoxicity of pharmaceuticals within a 28-day oral toxicity study using azathioprine and cyclosporin A as model compounds. Regul Toxicol Pharmacol 21, 327-338.

157. Lebrec, H., Roger, R., Blot, C., Burleson, G.R., Bohuon, C., Pallardy, M. (1995) Immunotoxicological investigation using pharmaceutical drugs. In vitro evaluation of immune effects using rodent or human immune cells. Toxicology 96, 147-156.

158. White, K.L., Kawabata, T.T., Ladics, G.S. (1994) Mechanisms of polycyclic aromatic hydrocarbon immunotoxicity. In: Immunotoxicology and Immunopharmacology (Dean JH, Luster MI, Munson AE, Kimber I Eds) 123-142. Raven Press Ltd, New York, USA.

159. De Jong, W.H., Kroese, E.D., Vos, J.G., Van Loveren, H. (1999) Detection of immunotoxicity of benzo[a]pyrene in a subacute toxicity study after oral exposure in rats. Toxicol Sci 50, 214-220.

160. Bertolini, A., Ferrari, A., Ottani, A., Guerzoni, S., Tacchi, R., Leone, S. (2006) Paracetamol: new vistas of an old drug. CNS Drug Rev 12, 250-275.

161. Bessems, J.G., Vermeulen, N.P. (2001) Paracetamol (acetaminophen)-induced toxicity: molecular and biochemical mechanisms, analogues and protective approaches. Crit Rev Toxicol 31, 55-138.

162. Kaplowitz, N. (2004) Acetaminophen hepatoxicity: what do we know, what don't we know, and what do we do next? Hepatology 40, 23-26.

163. Coen, M., Ruepp, S.U., Lindon, J.C., Nicholson, J.K., Pognan, F., Lenz, E.M., Wilson, I.D. (2004) Integrated application of transcriptomics and metabonomics yields new insight into the toxicity due to paracetamol in the mouse. J Pharm Biomed Anal 35, 93-105.

164. Fukushima, T., Kikkawa, R., Hamada, Y., Horii, I. (2006) Genomic cluster and network analysis for predictive screening for hepatotoxicity. J Toxicol Sci 31, 419-432.

165. Harris, A.J., Dial, S.L., Casciano, D.A. (2004) Comparison of basal gene expression profiles and effects of hepatocarcinogens on gene expression in cultured primary human hepatocytes and HepG2 cells. Mutat Res 549, 79-99.

166. Heinloth, A.N., Irwin, R.D., Boorman, G.A., Nettesheim, P., Fannin, R.D., Sieber, S.O., Snell, M.L., Tucker, C.J., Li, L., Travlos, G.S., Vansant, G., Blackshear, P.E., Tennant, R.W., Cunningham, M.L., Paules, R.S. (2004) Gene expression profiling of rat livers reveals indicators of potential adverse effects. Toxicol Sci 80 , 193-202.

167. Huang, Q., Jin, X., Gaillard, E.T., Knight, B.L., Pack, F.D., Stoltz, J.H., Jayadev, S., Blanchard, K.T. (2004) Gene expression profiling reveals multiple toxicity endpoints induced by hepatotoxicants. Mutat Res 549, 147-167.

168. Irwin, R.D., Parker, J.S., Lobenhofer, E.K., Burka, L.T., Blackshear, P.E., Vallant, M.K., Lebetkin, E.H., Gerken, D.F., Boorman, G.A. (2005) Transcriptional profiling of the left and median liver lobes of male f344/n rats following exposure to acetaminophen. Toxicol Pathol 33, 111-117. 
169. Minami, K., Saito, T., Narahara, M., Tomita, H., Kato, H., Sugiyama, H., Katoh, M., Nakajima, M., Yokoi, T. (2005) Relationship between hepatic gene expression profiles and hepatotoxicity in five typical hepatotoxicant-administered rats. Toxicol Sci 87, 296-305.

170. Powell, C.L., Kosyk, O., Ross, P.K., Schoonhoven, R., Boysen, G., Swenberg, J.A., Heinloth, A.N., Boorman, G.A., Cunningham, M.L., Paules, R.S., Rusyn, I. (2006) Phenotypic anchoring of acetaminophen-induced oxidative stress with gene expression profiles in rat liver. Toxicol Sci 93, 213-222.

171. Reilly, T.P., Bourdi, M., Brady, J.N., Pise-Masison, C.A., Radonovich, M.F., George, J.W., Pohl, L.R. (2001) Expression profiling of acetaminophen liver toxicity in mice using microarray technology. Biochem Biophys Res Commun 282, 321-328.

172. Ruepp, S.U., Tonge, R.P., Shaw, J., Wallis, N., Pognan, F. (2002) Genomics and proteomics analysis of acetaminophen toxicity in mouse liver. Toxicol Sci 65, 135-150.

173. Williams, D.P., Garcia-Allan, C., Hanton, G., LeNet, J.L., Provost, J.P., Brain, P., Walsh, R., Johnston, G.I., Smith, D.A., Park, B.K. (2004) Time course toxicogenomic profiles in CD-1 mice after nontoxic and nonlethal hepatotoxic paracetamol administration. Chem Res Toxicol 17, 1551-1561.

174. Doran, T.F., De Angelis, C., Baumgardner, R.A., Mellits, E.D. (1989) Acetaminophen: more harm than good for chickenpox? J Pediatr 114, 1045-1048.

175. Fyfe, A.I., Wright, J.M. (1990) Chronic acetaminophen ingestion associated with $(1 ; 7)(\mathrm{p} 11 ; \mathrm{p} 11)$ translocation and immune deficiency syndrome. Am J Med 88, 443-444.

176. Graham, N.M., Burrell, C.J., Douglas, R.M., Debelle, P., Davies, L. (1990) Adverse effects of aspirin, acetaminophen, and ibuprofen on immune function, viral shedding, and clinical status in rhinovirus-infected volunteers. J Infect Dis 162, 1277-1282.

177. Ueno, K., Yamaura, K., Nakamura, T., Satoh, T., Yano, S. (2000) Acetaminophen-induced immunosuppression associated with hepatotoxicity in mice. Res Commun Mol Pathol Pharmacol 108, 237251.

178. Yamaura, K., Ogawa, K., Yonekawa, T., Nakamura, T., Yano, S., Ueno, K. (2002) Inhibition of the antibody production by acetaminophen independent of liver injury in mice. Biol Pharm Bull 25, 201-205.

179. Gill, H.S., Guarner, F. (2004) Probiotics and human health: a clinical perspective. Postgrad Med J 80, 516526.

180. Noverr, M.C., Huffnagle, G.B. (2004) Does the microbiota regulate immune responses outside the gut? Trends Microbiol 12, 562-568.

181. Vijaya Kumar, S.G., Singh, S.K., Goyal, P., Dilbaghi, N., Mishra, D.N. (2005) Beneficial effects of probiotics and prebiotics on human health. Pharmazie 60, 163-171.

182. de Vrese, M., Schrezenmeir, J. (2002) Probiotics and non-intestinal infectious conditions. Br J Nutr 88 Suppl 1, S59-S66.

183. Ezendam, J., Van Loveren, H. (2006) Probiotics: immunomodulation and evaluation of safety and efficacy. Nutr Rev 64, 1-14.

184. Isolauri, E., Sutas, Y., Kankaanpaa, P., Arvilommi, H., Salminen, S. (2001) Probiotics: effects on immunity. Am J Clin Nutr 73, 444S-450S.

185. Miettinen, M., Matikainen, S., Vuopio-Varkila, J., Pirhonen, J., Varkila, K., Kurimoto, M., Julkunen, I. (1998) Lactobacilli and streptococci induce interleukin-12 (IL-12), IL-18, and gamma interferon production in human peripheral blood mononuclear cells. Infect Immun 66, 6058-6062.

186. Chapat, L., Chemin, K., Dubois, B., Bourdet-Sicard, R., Kaiserlian, D. (2004) Lactobacillus casei reduces CD8+ T cell-mediated skin inflammation. Eur J Immunol 34, 2520-2528.

187. Gill, H.S., Rutherfurd, K.J., Prasad, J., Gopal, P.K. (2000) Enhancement of natural and acquired immunity by Lactobacillus rhamnosus (HN001), Lactobacillus acidophilus (HN017) and Bifidobacterium lactis (HN019). Br J Nutr 83, 167-176.

188. Hart, A.L., Stagg, A.J., Kamm, M.A. (2003) Use of probiotics in the treatment of inflammatory bowel disease. J Clin Gastroenterol 36, 111-119.

189. Kalliomaki, M., Salminen, S., Poussa, T., Arvilommi, H., Isolauri, E. (2003) Probiotics and prevention of atopic disease: 4-year follow-up of a randomised placebo-controlled trial. Lancet 361, 1869-1871.

190. Marteau, P.R., De Vrese, M., Cellier, C.J., Schrezenmeir, J. (2001) Protection from gastrointestinal diseases with the use of probiotics. Am J Clin Nutr 73, 430S-436S.

191. Perdigon, G., Alvarez, S., Rachid, M., Aguero, G., Gobbato, N. (1995) Immune system stimulation by probiotics. J Dairy Sci 78, 1597-1606.

192. Sartor, R.B. (2005) Probiotic therapy of intestinal inflammation and infections. Curr Opin Gastroenterol 21, 44-50.

193. Christensen, H.R., Frokiaer, H., Pestka, J.J. (2002) Lactobacilli differentially modulate expression of cytokines and maturation surface markers in murine dendritic cells. J Immunol 168, 171-178. 
194. Cross, M.L., Ganner, A., Teilab, D., Fray, L.M. (2004) Patterns of cytokine induction by gram-positive and gram-negative probiotic bacteria. FEMS Immunol Med Microbiol 42, 173-180.

195. Hessle, C., Hanson, L.A., Wold, A.E. (1999) Lactobacilli from human gastrointestinal mucosa are strong stimulators of IL-12 production. Clin Exp Immunol 116, 276-282.

196. Miettinen, M., Vuopio-Varkila, J., Varkila, K. (1996) Production of human tumor necrosis factor alpha, interleukin-6, and interleukin-10 is induced by lactic acid bacteria. Infect Immun 64, 5403-5405.

197. Mohamadzadeh, M., Olson, S., Kalina, W.V., Ruthel, G., Demmin, G.L., Warfield, K.L., Bavari, S., Klaenhammer, T.R. (2005) Lactobacilli activate human dendritic cells that skew T cells toward T helper 1 polarization. Proc Natl Acad Sci U S A 102, 2880-2885.

198. Pochard, P., Gosset, P., Grangette, C., Andre, C., Tonnel, A.B., Pestel, J., Mercenier, A. (2002) Lactic acid bacteria inhibit $\mathrm{TH} 2$ cytokine production by mononuclear cells from allergic patients. J Allergy Clin Immunol 110, 617-623.

199. Baharav, E., Mor, F., Halpern, M., Weinberger, A. (2004) Lactobacillus GG bacteria ameliorate arthritis in Lewis rats. J Nutr 134, 1964-1969.

200. Calcinaro, F., Dionisi, S., Marinaro, M., Candeloro, P., Bonato, V., Marzotti, S., Corneli, R.B., Ferretti, E., Gulino, A., Grasso, F., De Simone, C., Di Mario, U., Falorni, A., Boirivant, M., Dotta, F. (2005) Oral probiotic administration induces interleukin-10 production and prevents spontaneous autoimmune diabetes in the nonobese diabetic mouse. Diabetologia 48, 1565-1575.

201. de Waard, R., Garssen, J., Bokken, G.C., Vos, J.G. (2002) Antagonistic activity of Lactobacillus casei strain Shirota against gastrointestinal Listeria monocytogenes infection in rats. Int J Food Microbiol 73, 93-100.

202. de Waard, R., Claassen, E., Bokken, G.C., Buiting, B., Garssen, J., Vos, J.G. (2003) Enhanced immunological memory responses to Listeria monocytogenes in rodents, as measured by delayed-type hypersensitivity (DTH), adoptive transfer of DTH, and protective immunity, following Lactobacillus casei Shirota ingestion. Clin Diagn Lab Immunol 10, 59-65.

203. Erickson, K.L., Hubbard, N.E. (2000) Probiotic immunomodulation in health and disease. J Nutr 130, 403S409s.

204. Hori, T., Kiyoshima, J., Yasui, H. (2003) Effect of an oral administration of Lactobacillus casei strain Shirota on the natural killer activity of blood mononuclear cells in aged mice. Biosci Biotechnol Biochem 67, 420-422.

205. Kato, I., Endo-Tanaka, K., Yokokura, T. (1998) Suppressive effects of the oral administration of Lactobacillus casei on type II collagen-induced arthritis in DBA/1 mice. Life Sci 63, 635-644.

206. Kato, I., Tanaka, K., Yokokura, T. (1999) Lactic acid bacterium potently induces the production of interleukin12 and interferon-gamma by mouse splenocytes. Int $\mathrm{J}$ Immunopharmacol 21, 121-131.

207. Matsuzaki, T., Yamazaki, R., Hashimoto, S., Yokokura, T. (1998) The effect of oral feeding of Lactobacillus casei strain Shirota on immunoglobulin E production in mice. J Dairy Sci 81, 48-53.

208. Matsuzaki, T. (1998) Immunomodulation by treatment with Lactobacillus casei strain Shirota. Int J Food Microbiol 41, 133-140.

209. Matsuzaki, T., Chin, J. (2000) Modulating immune responses with probiotic bacteria. Immunol Cell Biol 78, 67-73.

210. Matsuzaki, T., Takagi, A., Ikemura, H., Matsuguchi, T., Yokokura, T. (2007) Intestinal microflora: probiotics and autoimmunity. J Nutr 137, 798S-802S.

211. Nagao, F., Nakayama, M., Muto, T., Okumura, K. (2000) Effects of a fermented milk drink containing Lactobacillus casei strain Shirota on the immune system in healthy human subjects. Biosci Biotechnol Biochem 64, 2706-2708.

212. Shida, K., Takahashi, R., Iwadate, E., Takamizawa, K., Yasui, H., Sato, T., Habu, S., Hachimura, S., Kaminogawa, S. (2002) Lactobacillus casei strain Shirota suppresses serum immunoglobulin E and immunoglobulin G1 responses and systemic anaphylaxis in a food allergy model. Clin Exp Allergy 32, 563570.

213. Takagi, A., Matsuzaki, T., Sato, M., Nomoto, K., Morotomi, M., Yokokura, T. (2001) Enhancement of natural killer cytotoxicity delayed murine carcinogenesis by a probiotic microorganism. Carcinogenesis 22, 599-605.

214. Yasui, H., Shida, K., Matsuzaki, T., Yokokura, T. (1999) Immunomodulatory function of lactic acid bacteria. Antonie Van Leeuwenhoek 76, 383-389.

215. Yasui, H., Kiyoshima, J., Hori, T. (2004) Reduction of influenza virus titer and protection against influenza virus infection in infant mice fed Lactobacillus casei Shirota. Clin Diagn Lab Immunol 11, 675-679.

216. Corthesy, B., Gaskins, H.R., Mercenier, A. (2007) Cross-talk between probiotic bacteria and the host immune system. J Nutr 137, 781S-790S.

217. Kimber, I., Weisenberger, C. (1989) A murine local lymph node assay for the identification of contact allergens. Assay development and results of an initial validation study. Arch Toxicol 63, 274-282.

218. Pearse, G. (2006) Histopathology of the thymus. Toxicol Pathol 34, 515-547.

219. Drela, N. (2006) Xenobiotic-induced alterations in thymocyte development. APMIS 114, 399-419. 
220. Fujiwara, D., Inoue, S., Wakabayashi, H., Fujii, T. (2004) The anti-allergic effects of lactic acid bacteria are strain dependent and mediated by effects on both Th1/Th2 cytokine expression and balance. Int Arch Allergy Immunol 135, 205-215.

221. Maassen, C.B., Van Holten, J.C., Balk, F., Heijne den Bak-Glashouwer MJ, Leer, R., Laman, J.D., Boersma, W.J., Claassen, E. (1998) Orally administered Lactobacillus strains differentially affect the direction and efficacy of the immune response. Vet Q 20 Suppl 3, S81-S83. 



\section{2}

\section{Use of the Local Lymph Node Assay in assessment of immune function}

Toxicology (2005) 211: 107-114

F.A. van den Berg ${ }^{1,3}$

K.A. Baken

J.P. Vermeulen ${ }^{1}$

E.R. Gremmer ${ }^{1}$

H. van Steeg ${ }^{1}$

H. van Loveren ${ }^{1,2}$

${ }^{1}$ Department of Toxicology, Pathology and Genetics, National Institute for Public Health and the Environment, Bilthoven, The Netherlands

${ }^{2}$ Department of Health Risk Analysis and Toxicology, Maastricht University, Maastricht, The Netherlands

${ }^{3}$ Department of Toxicogenetics, Leiden University Medical Center, Leiden, The Netherlands 


\title{
Chapter 2
}

\begin{abstract}
The murine local lymph node assay (LLNA) was originally developed as a predictive test method for the identification of chemicals with sensitizing potential. In this study we demonstrated that an adapted LLNA can also be used as an immune function assay by studying the effects of orally administered immunomodulating compounds on the $\mathrm{T}$ celldependent immune response induced by the contact sensitizer 2,4-dinitrochlorobenzene (DNCB). C57BL/6 mice were treated with the immunotoxic compounds cyclosporin $A$ (CsA), bis(tri-n-butyltin)oxide (TBTO) or benzo[a]pyrene, (B[a]P). Subsequently, cell proliferation and interferon (IFN)- $\gamma$ and interleukin (IL)-4 release were determined in the auricular lymph nodes after DNCB application on both ears. Immunosuppression induced by CsA, TBTO and B[a]P was clearly detectable in this application of the LLNA. Cytokine release measurements proved valuable to confirm the results of the cell proliferation assay and to obtain an indication of the effect on T helper (Th)1/Th2 balance. We believe to have demonstrated the applicability of an adapted LLNA as an immune function assay in the mouse.
\end{abstract}




\section{Introduction}

The murine local lymph node assay (LLNA) was originally developed as a predictive test method for the identification of chemicals that have the potential to cause sensitization $[1,2]$. This assay has been validated extensively and is nowadays commonly used to uncover allergenicity [3]. In the LLNA, lymphocyte proliferation in draining lymph nodes is used as a measure for the immune response to an applied allergen. As such, the LLNA can be seen as a functional assay of immune reactivity to $T$ cell-dependent antigens, which is suggested to be applicable in the study of direct effects on the immune system after exposure to (toxic) compounds [4,5].

In this study we applied the LLNA in combination with cytokine Enzyme-Linked Immunosorbent Assays (ELISAs) to demonstrate immunomodulating effects of various orally administered substances. For this purpose, groups of mice were exposed to control or test diets prior to sensitization with a T cell-dependent, low molecular weight antigen. The lymphocyte activation in the animals exposed to the test agents was then compared to that in the control animals. An immunosuppressive or -stimulating effect of the test agent would thus be expressed by a diminished or enhanced proliferative and cytokine response of lymphocytes after application of the sensitizer.

The $T$ cell-dependent low molecular weight antigen used to induce immune responses was 2,4-dinitrochlorobenzene (DNCB). DNCB is a well-known contact sensitizer that induces a $\mathrm{T}$ helper (Th) 1 response and interferon (IFN)- $\mathrm{Y}$ and interleukin (IL)-2 production [6]. Cyclosporin A (CsA), bis(tri- $n$-butyltin)oxide (TBTO) and benzo[a]pyrene $(\mathrm{B}[\mathrm{a}] \mathrm{P})$ were the test substances used. These compounds are known immunotoxicants with different modes of action and employed here as model compounds to show the usefulness of the LLNA as an immune function assay. The immunosuppressive drug CsA is used after organ and bone marrow transplantation and in treatment of autoimmune diseases. CsA primarily interferes with $\mathrm{T}$ cell proliferation by affecting transcription of several genes encoding growth and differentiation factors (such as cytokines), cell surface receptors and a transcription factor [7]. Some of these genes are under control of the transcription factor Nuclear Factor of Activated T cells (NFAT) that needs to be dephosphorylated by the protein phosphatase calcineurin to be able to translocate to the nucleus and activate target genes. CsA binds to cyclophilin, after which this complex binds and thereby inhibits calcineurin [8,9]. Furthermore, recent studies suggests that promotion of transcription of certain (partially immunologically relevant) genes by CsA or binding of CsA to specific surface receptors could contribute to its effects as well [9-11]. In addition to the immunosuppressive effects, CsA treatment turned out to promote development of lymphoid and skin cancers [12,13].

TBTO is a persistent organotin compound that is used as a biocide, e.g. in antifouling paints, and accordingly occurs as an environmental pollutant. This chemical has been shown to cause immunosuppression in rats and consequently reduction of resistance to infections. This is mainly due to a decreased cellular immune response caused by a direct action of TBTO on cortical thymocytes, but also to the effect of TBTO on nonspecific immune functions like NK cell and macrophage activity [14-16]. Whether the observed thymus atrophy after TBTO exposure is caused by induction of apoptosis or antiproliferative effects is still unclear $[15,17]$. 
The combustion product $\mathrm{B}[\mathrm{a}] \mathrm{P}$ is the prototype immunotoxic polycylic aromatic hydrocarbon (PAH) and also the first carcinogenic compound isolated from coal tar [18]. The effect of $\mathrm{B}[\mathrm{a}] \mathrm{P}$ on the immune system manifests itself generally in atrophy or decreased cellularity in spleen, thymus and bone marrow and a reduction of circulating red and white blood cells and immunoglobulins [19]. The exact mechanism of B[a]P-induced immunosuppression still remains to be established. Potential effects of $B[a] P$ or its reactive metabolites (formed by cytochrome P450 enzymes, possibly particularly in macrophages) that could be involved are binding to the aryl hydrocarbon receptor (AhR), entering cell membranes and interference with its function, affecting production of various interleukins or alterating mobilization of intracellular calcium [18]. Metabolic activation of B[a]P is also associated with its genotoxic effect in various tissues [20,21]. In addition, B[a]P was shown to have sensitizing capacity after application to the skin in the standard LLNA [22].

Our findings show that the LLNA offers a simple approach to demonstrate immunosupression by orally administered agents.

\section{Materials and Methods}

\section{Animals}

Male and female C57BL/6 mice of 6-9 weeks old were obtained from Charles River Laboratories (Someren, The Netherlands). We performed the LLNA in the C57BL/6 strain instead of the traditionally used CBA mice because these experiments were part of a larger study in which C57BL/6 mice were used also. These mice are comparable to CBA mice with regard to Th1 responses, such as the response to DNCB, as shown by Woolhiser et al. [23]. The animals were bred specific pathogen free and housed in macrolon cages under conventional conditions.

\section{Treatment}

The mice were randomly divided over the treatment groups. For every treatment group a separate control group was included. During 4 weeks C57BL/6 mice were fed a standard diet (SRM-A food, Hope farms Arie Blok, Woerden, The Netherlands) or similar food mixed with $300 \mathrm{ppm}$ of TBTO (Sigma-Aldrich, Zwijndrecht, The Netherlands) or with $500 \mathrm{ppm}$ of CsA (Kindly provided by Novartis Pharma AG; Basel, Switzerland), both feed mixtures were manufactured at Altromin (Lage, Germany). B[a]P (Purpose-made by Serva, Germany), dissolved in $0.1 \mathrm{ml}$ sunflower oil, was given by gavage three times a week at a dose of $13 \mathrm{mg} / \mathrm{kg}$ body weight. The administered doses of CsA, TBTO and B[a]P corresponded to the maximum tolerated doses (MTDs), here defined as the dose that causes a ten percent reduction in body weight gain along the growth curve compared to the control group.

Standard diet, the diets containing CsA or TBTO and water were given ad libitum. The mice that received $\mathrm{B}[\mathrm{a}] \mathrm{P}$ orally, had free access to standard diet during the treatment. 


\section{Sensitization}

Immediately after the 4 week treatment period with CsA, TBTO and B[a]P, for every different treatment group four mice were topically exposed to DNCB $(2,4-$ dinitrochlorobenzene 98\%; Sigma-Aldrich) (25 $\mu \mathrm{l})$ dissolved in acetone:olive oil (4:1) (AOO) on the dorsum of both ears. The DNCB concentrations used were $1 \%, 0.66 \%$, $0.33 \%$ and $0 \%(\mathrm{w} / \mathrm{v})$. DNCB application was performed daily for three consecutive days. During these days the mice were given standard diet ad libitum.

\section{Cell isolation}

In contrast to the LLNA, we have not labeled lymphocytes in the auricular lymph nodes with $\left[{ }^{3} \mathrm{H}\right]$-thymidine in vivo, but rather harvested the lymphocytes, and labeled them ex vivo. For this reason, we use the term adapted LLNA.

Three days after the last topical application of DNCB to the ears, the mice were euthanized by $\mathrm{CO}_{2} / \mathrm{O}_{2}$ exposure and the auricular lymph nodes (LNs) were excised. The LNs were pooled for each animal, weighed and suspended in $5 \mathrm{ml}$ RPMI 1640 (Gibco, Life Technologies, Breda, The Netherlands) with $5 \%$ heat inactivated Fetal Calf Serum (FCS) (PAA, Linz, Austria), $100 \mathrm{U} / \mathrm{ml}$ penicillin and $100 \mu \mathrm{g} / \mathrm{ml}$ streptomycin (standard medium). Single cell suspensions were prepared by pressing the LNs trough a $70 \mu \mathrm{m}$ nylon cell strainer (Falcon, Franklin Lakes, USA). The cells were washed twice in standard medium (10 min $300 \mathrm{~g}, 4{ }^{\circ} \mathrm{C}$ ) and resuspended in $1 \mathrm{ml}$ standard medium with $10 \%$ FCS. A Coulter Counter (Z2, Coulter Electronics, Mijdrecht, The Netherlands) was used to count the cells. Then the concentration of the cell suspensions was adjusted to $1 \times 10^{7}$ cells $/ \mathrm{ml}$. Some cell suspensions of AOO-treated animals were pooled, because the number of cells per animal was insufficient to perform the subsequent assays. Then the averages of the cell counts of the pooled lymph nodes were used for further calculations.

\section{Cell proliferation}

Of each cell suspension of $1 \times 10^{7}$ cells $/ \mathrm{ml}, 200 \mu \mathrm{l}$ was seeded in triplicate in a U-bottom 96-wells plate (Greiner, Alphen aan den Rijn, The Netherlands). After addition of $10 \mu \mathrm{l} /$ well $(=1 \mu \mathrm{Ci})$ [methyl- ${ }^{3} \mathrm{H}$ ]-thymidine (Amersham Biosciences,Buckinghamshire,UK) the cells were incubated at $37{ }^{\circ} \mathrm{C}$ in a humidified atmosphere containing $5 \% \mathrm{CO}_{2}$ during $20-24 \mathrm{~h}$. The cells were harvested on glass-fiber filters (LKB-Wallac, Turku, Finland) using a multiple cell culture harvester (LKB-Wallac). The $\left[{ }^{3} \mathrm{H}\right]$-thymidine activity was determined using a liquid scintillation counter (1205 Betaplate TM, LKB-Wallac). For further calculations the median of the triplicates was used. The $\left[{ }^{3} \mathrm{H}\right]$-thymidine incorporation is expressed per set of LNs, being the mean of the measured counts per minute (cpm) per group times the mean total LN cell number per group \pm SEM. 


\section{Cytokine release}

$100 \mu \mathrm{l}$ of the cell suspension of $1 \times 10^{7}$ cells $/ \mathrm{ml}$ was seeded in duplicate in a 24-wells plate (Greiner). The cells were incubated at $37{ }^{\circ} \mathrm{C}$ in a humidified atmosphere for $20-24 \mathrm{~h}$ in the presence of the mitogen concanavalin A (ConA, ICN Biochemicals, Irvine, USA). The supernatant was harvested and used in an ELISA to measure the amount of IFN- $\gamma$ and IL4. For the IFN-y ELISA, MaxiSorp 96 wells flat-bottom plates (Nunc-Immuno Plate, Denmark) were coated overnight at $4{ }^{\circ} \mathrm{C}$ with $2 \mu \mathrm{g} / \mathrm{ml}$ rat anti-mouse IFN- $\mathrm{\gamma}$ (Pharmingen, San Diego, CA) in coating buffer (0.04 M carbonate buffer $\mathrm{pH} 9.6)$. Then the plates were incubated in blocking buffer (PBS with $0.1 \%$ Tween-20 (Merck, Amsterdam, the Netherlands) containing $1 \%(\mathrm{w} / \mathrm{v})$ blocking reagent (NEN $3 \mathrm{GM})$ for $2 \mathrm{~h}$ at $37{ }^{\circ} \mathrm{C}$ or overnight at $4{ }^{\circ} \mathrm{C}$ and washed (PBS plus $0.1 \%$ Tween-20) on an Auto Plate Washer (ELx405, Bio-Tek, Instruments, Inc.). Recombinant mouse IFN-ץ (Pharmingen) was used as a standard. Serial dilutions of the standard as well as the culture supernatants were added to the plate $(100 \mu \mathrm{l} / \mathrm{well})$. Biotinylated rat anti-mouse IFN- $\gamma(0.1 \mu \mathrm{g} / \mathrm{ml})$ (Pharmingen) was added $\left(50 \mu \mathrm{l} /\right.$ well) and the plates were incubated at $37^{\circ} \mathrm{C}$ for $2 \mathrm{~h}$ under continuous shaking. The plates were washed and poly horseradish peroxidase labeled streptavidin (10,000-fold dilution, CLB, Amsterdam, the Netherlands) was added, after which the plates were incubated for $45 \mathrm{~min}$ under continuous shaking. Plates were washed again and TMB/DMSO solution (1.6\% tetramethylbenzidine (TMB, Sigma) in dimethyl sulfoxide (DMSO, Fluka), 9.8\% sodiumacetate $(1.1 \mathrm{M}), \mathrm{pH} 5,5,0.02 \%$ perhydrol $(30 \%$, Merck)) was added. The reaction was terminated with $\mathrm{H}_{2} \mathrm{SO}_{4}(50 \mu \mathrm{l} /$ well) $(10 \%$, Merck) and the absorbance was read at $450 \mathrm{~nm}$, using an automated multichannel photometer (Titertek Multiscan MCC/340, Merlin Diagnostics System B.V.). Standard curves were used to calculate the cytokine release.

For IL-4, a similar protocol was used with $1 \mu \mathrm{g} / \mathrm{ml}$ rat anti-mouse IL-4 (Pharmingen) for coating, blocking with blocking buffer containing $1 \%(\mathrm{w} / \mathrm{v})$ dried milk, recombinant mouse IL-4 (Biosource, Camarillo, CA) as a standard and $0.4 \mu \mathrm{g} / \mathrm{ml}$ biotinylated rat anti-mouse IL-4 (Pharmingen) for detection.

Antibodies, standards, samples and streptavidin were diluted in dilution buffer containing PBS plus $0.1 \%$ Tween-20. $0.5 \%$ blocking reagent (IFN- $\mathrm{\gamma}$ ) or $0.5 \%$ dried milk (IL-4) were added.

The cytokine release is expressed per set of auricular LNs, being the mean of the measured picograms $(\mathrm{pg})$ per group times the mean total LN cell number per group \pm SEM.

\section{Statistical analysis}

For the cell proliferation assay as well as the cytokine release assay, statistical analysis was performed using one-way analysis of variance (ANOVA). Significant differences of the control group were determined with the Bonferroni post hoc test, using a significance level of $p=0.05$. 


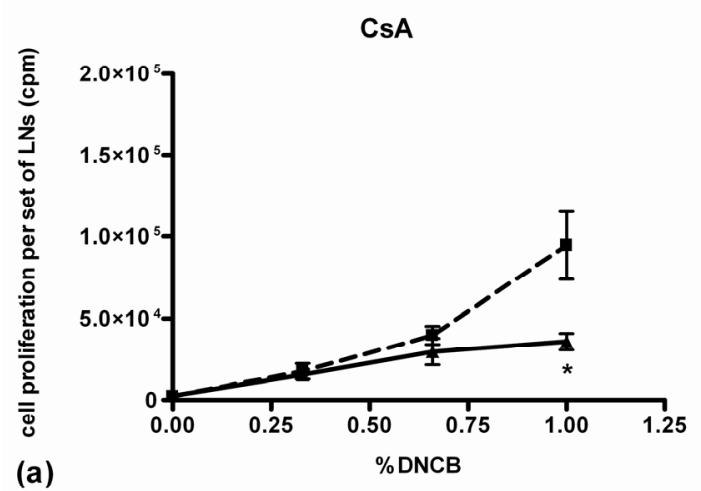

TBTO
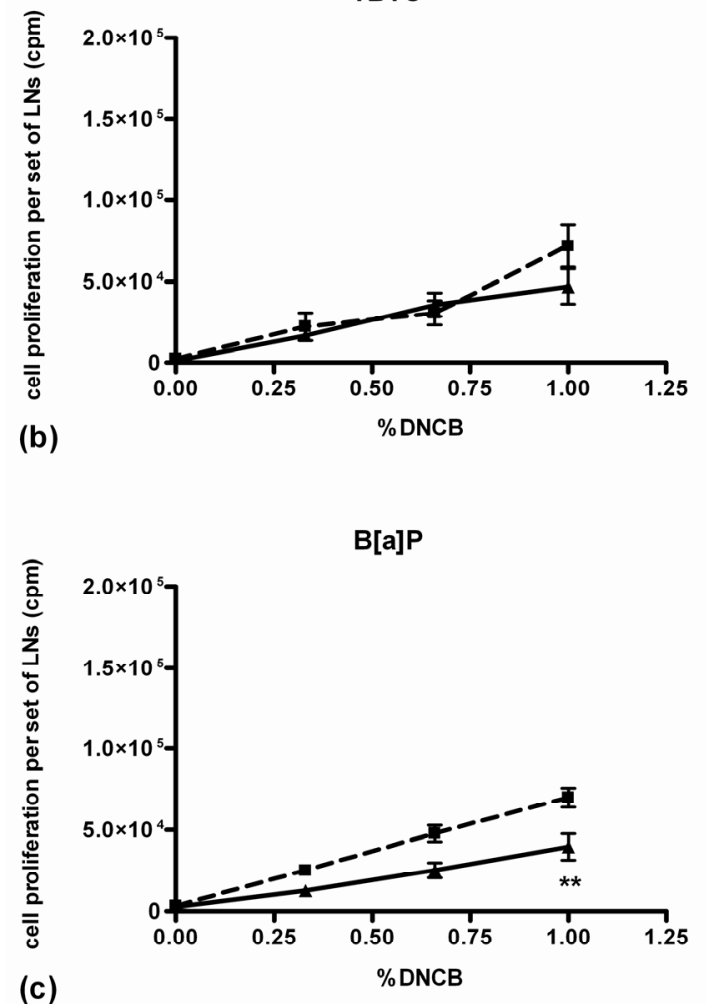

\section{Figure 1.}

$\left[{ }^{3} \mathrm{H}\right]$-thymidine incorporation in auricular LN cells of C57BL/6 mice after treatment with different immunosuppressive compounds. Mice were treated during 4 weeks with CsA (a), TBTO (b), or B[a]P (c) $(n=16,8$ females and 8 males). These mice (A) as well as the untreated animals (a) (similar group sizes) were subdivided in groups $(n=4,2$ females and 2 males) for the different DNCB concentrations $(0 \%, 0.33 \%, 0.66 \%$ and $1 \%)$. The $\left[{ }^{3} \mathrm{H}\right]$-thymidine incorporation is expressed per set of auricular LNs, being the mean of the measured counts per minute (cpm) per group times the mean total $L N$ cell number per group \pm SEM. Significance levels are ${ }^{*} p<0.05$ and ${ }^{* *} p<0.01$. 
IL-4

CsA

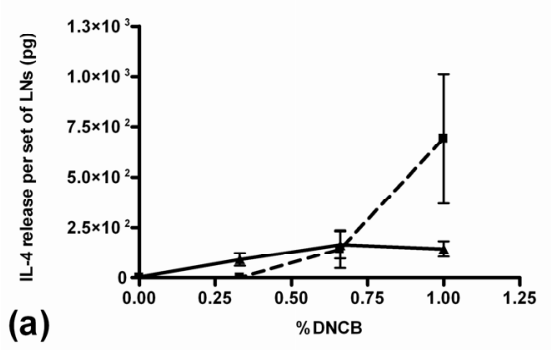

Tвто

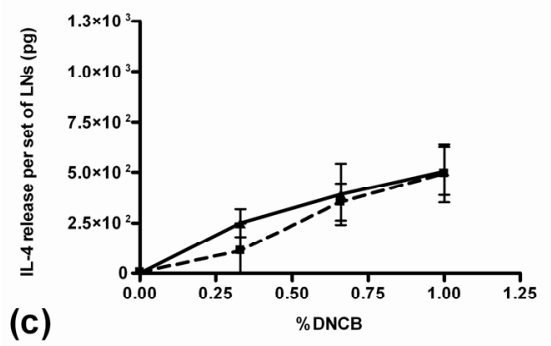

B[a]P

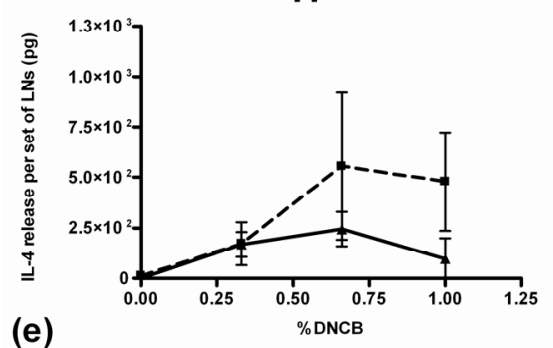

IF $\mathrm{N}-\gamma$

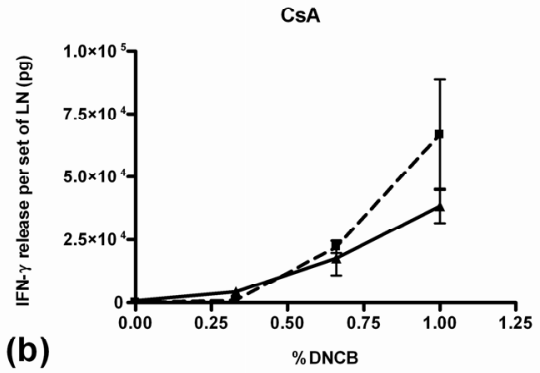

TBTO

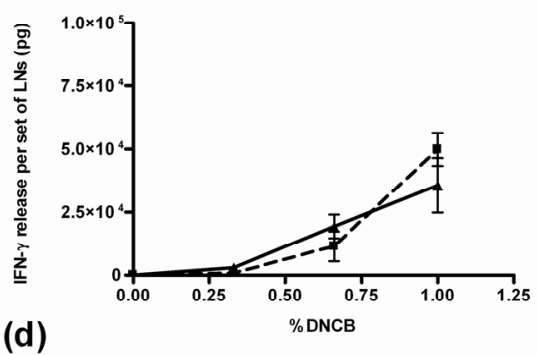

B[a]P

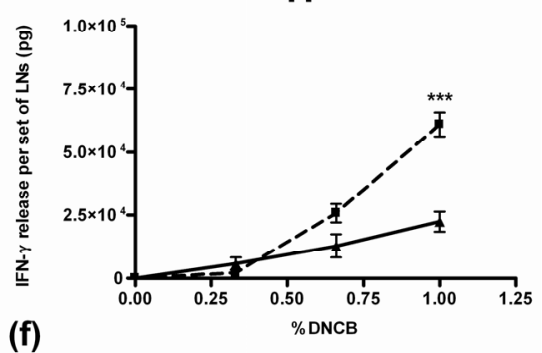

\section{Figure 2.}

The release of IL-4 and IFN- $\gamma$ in auricular LN cells of C57BL/6 mice after treatment with different immunosuppressive compounds. Mice were treated during 4 weeks with CsA (a,b), TBTO (c,d), or $\mathrm{B}[\mathrm{a}] \mathrm{P}(\mathrm{e}, \mathrm{f})(\mathrm{n}=16,8$ females and 8 males). These mice $(\boldsymbol{\Delta})$ as well as the untreated animals $(\boldsymbol{\square})$ (similar group sizes) were subdivided in groups $(n=4,2$ females and 2 males) for the different DNCB concentrations $(0 \%, 0.33 \%, 0.66 \%$ and $1 \%)$. The cytokine release is expressed per set of auricular LNs, being the mean of the measured picograms (pg) per group times the mean total LN cell number per group \pm SEM. Significance level is ${ }^{* *} p<0.001$. 


\section{Results}

\section{Cell proliferation}

The effects of the treatments with immunomodulating compounds on DNCB induced lymphocyte proliferation in draining LNs are shown in Figure 1. Treatment of C57BL/6 mice with $\mathrm{CsA}$, TBTO or B[a]P resulted in a reduction of the $\left[{ }^{3} \mathrm{H}\right]$-thymidine incorporation in comparison with the control mice. Figure 1a shows that the reduction of $\left[{ }^{3} \mathrm{H}\right]$-thymidine incorporation after CsA exposure was significant $(p=0.032)$ in the highest DNCB treatment group. After $B[a] P$ exposure (Figure 1c) the incorporation was also significantly reduced ( $p$ $=0.008$ ) in the highest DNCB group. As shown in Figure 1b, the TBTO exposed mice showed a similar pattern, but here the reduction was not statistically significant.

Cytokine release

Analyses of cytokine release in supernatant of the cultures of draining $\mathrm{LN}$-cells were performed for IL-4 and IFN- $\gamma$. Figure 2 shows that in the groups exposed to the highest DNCB concentration, both the IL-4 and IFN- $\gamma$ release were decreased for the mice treated with CsA or B[a]P compared to the non-treated control mice. TBTO only suppressed IFN$y$ release at that concentration. Only the reduction of the IFN- $\gamma$ release after $B[a] P$ exposure (Figure $2 f)$ at $1 \%$ DNCB was statistically significant $(p<0.001)$.

Table 1 summarizes the ratios of IFN- $y$ and IL-4 release in the $1 \%$ DNCB group for every treatment group and matching control group. TBTO exposed mice had a lower ratio than the control group, whereas the CsA and $\mathrm{B}[\mathrm{a}] \mathrm{P}$ exposed mice showed a higher ratio than their control group. 


\section{Discussion}

The murine LLNA is currently being used to identify compounds having a sensitizing capacity $[1,2]$. The aim of the present study was to demonstrate that the LLNA can also be employed as an immune function assay. By applying a contact sensitizer that induces a T cell-dependent immune response, the effects of immunomodulating compounds on this response can manifest themselves in effects on the cell proliferation and cytokine release pattern in draining lymph nodes.

We treated C57BL/6 mice with the known immunotoxic compounds CsA, TBTO and $B[a] P$. With regard to the results of the cell proliferation assay, the immunosuppressive effects of these compounds were demonstrated by reduction of the proliferative response in auricular LNs after DNCB application. These findings were confirmed by the cytokine release assays, which showed that IFN- $\gamma$ and IL-4 release in the LNs are reduced after treatment with the immunotoxic compounds. This effect was most overt in the group that was exposed to $1 \%$ DNCB. This finding was as expected, since the course of the proliferatory response after application of the allergen showed dose dependency. The effect of the highest DNCB concentration is thus the most pronounced and can consequently be influenced the most by treatment with immunomodulating compounds. This finding demonstrates that use of the most effective concentration of the applied allergen is important in detection of an effect of the treatment. It is therefore recommended to use a suitable dose-range of the allergen to rule out false-negative results.

We also used cytokine release patterns to determine whether a shift in the Th1/Th2 balance took place after exposure to the immunotoxic compounds compared to the control groups. IFN- $y$ was used to measure Th1 response and IL-4 for Th2 function. According to our results, CsA and B[a]P treatment caused a relative shift towards Th1dependent immunity whereas TBTO treatment led to a relatively more pronounced Th2 character. This may indicate that although all compounds showed overall immunosuppression, the nature of the effects that are involved may be different. Occurrence of such shifts in Th1/Th2 balance is of clinical importance with a view on induction or exacerbation of allergies or autoimmunity.

It is imaginable that the effects of orally administered immunosuppressive chemicals on the immune function and Th1/Th2 balance could be somewhat different when the animals are triggered to generate, for example, a Th2 response rather than a Th1 response, as induced by DNCB. Therefore, the results of our experiments could have been different if another sensitizer than DNCB would have been used. This is an interesting aspect that should be investigated in future experiments.

In the standard LLNA, B[a]P was found to have a sensitizing effect in auricular LNs when topically applied to the ear, as published by Ashby et al. [22]. One could wonder if this allergenic activity of $B[a] P$ has influenced our test results. However, whereas $B[a] P$ elicits sensitizing effects after application to the skin, oral administration of B[a]P would more readily lead to stimulatory effects in the mesenteric than in the auricular LNs. Although it cannot be ruled out that this sensitizing activity might have some impact on the process of sensitization to another allergen, it is not very likely that the draining lymph node response to a different compound (DNCB) that is applied locally (on the ear) will be influenced by the potential sensitizing effect of $\mathrm{B}[\mathrm{a}] \mathrm{P}$ after oral administration. It is exactly 
this determination of the local immune response to sensitizers in the LLNA that makes this test relatively insensitive to systemic allergenic influences of compounds on these immune responses. The systemic immunosuppressive effect of $\mathrm{B}[\mathrm{a}] \mathrm{P}$, though, is expected to influence the response in the auricular LN draining the ear on which DNCB is applied, and we indeed detected a reduced immune response to DNCB.

We administered MTDs of the immunotoxicants because these experiments were part of a larger study, performed with the same compounds. The aim of that study was to characterize patterns of gene expression in several tissues of the same mouse strain exposed to CsA, TBTO or B[a]P, in order to define the mechanisms that are involved in immunotoxicity and carcinogenesis. The results of the adapted LLNAs in the current study can now serve as proof of the immunosuppressive action of the compounds administered at this MTD. We are aware of the fact that lower doses of the chemicals would probably also have resulted in a diminished immune response to DNCB.

We conclude that the adapted LLNA was successfully applied here to detect immunosuppression after oral exposure to the immunotoxic agents CsA, TBTO and B[a]P. In contrast to Ravel et al. [24], we showed that the addition of cytokine release measurements proved valuable to confirm the results of the cell proliferation assay and to obtain an indication of the effect on Th1/Th2 balance. Therefore, we believe to have demonstrated the applicability of the adapted LLNA as an immune function assay in the mouse, which could as such be employed in hazard identification of potential immunomodulating compounds.

\section{Acknowledgements}

We thank Coen Moolenbeek, Ruud van Kinderen, Cor Schot, Paul Reulen, Christine Soputan en Ton de Liefde for their biotechnical support. This research was in part supported by CEFIC. 


\section{References}

1. Kimber, I., Weisenberger, C. (1989) A murine local lymph node assay for the identification of contact allergens. Assay development and results of an initial validation study. Arch Toxicol 63, 274-282.

2. Kimber, I., Mitchell, J.A., Griffin, A.C. (1986) Development of a murine local lymph node assay for the determination of sensitizing potential. Fd Chem Toxic 24, 585-586.

3. Kimber, I., Dearman, R.J., Basketter, D.A., Ryan, C.A., Gerberick, G.F. (2002) The local lymph node assay: past, present and future. Contact Dermatitis 47, 315-328.

4. Albers, R., Bol, M., Bleumink, R., Willems, A., Blonk, C., Pieters, R. (2002) Effects of dietary lipids on immune function in a murine sensitisation model. Br J Nutr 88, 291-299.

5. Albers, R., Bol, M., Bleumink, R., Willems, A.A., Pieters, R.H. (2003) Effects of supplementation with vitamins $A, C$, and $E$, selenium, and zinc on immune function in a murine sensitization model. Nutrition 19, 940-946.

6. Dearman, R.J., Basketter, D.A., Coleman, J.W., Kimber, I. (1992) The cellular and molecular basis for divergent allergic responses to chemicals. Chem Biol Interact 84, 1-10.

7. Kiani, A., Rao, A., Aramburu, J. (2000) Manipulating immune responses with immunosuppressive agents that target NFAT. Immunity 12, 359-372.

8. Ho, S., Clipstone, N., Timmermann, L., Northrop, J., Graef, I., Fiorentino, D., Nourse, J., Crabtree, G.R. (1996) The mechanism of action of cyclosporin A and FK506. Clin Immunol Immunopathol 80, S40-S45.

9. Mascarell, L., Truffa-Bachi, P. (2003) New aspects of cyclosporin a mode of action: from gene silencing to gene up-regulation. Mini Rev Med Chem 3, 205-214.

10. Allain, F., Denys, A., Spik, G. (1996) Cyclophilin B mediates cyclosporin A incorporation in human blood Tlymphocytes through the specific binding of complexed drug to the cell surface. Biochem J 317 ( Pt 2), 565570 .

11. Cacalano, N.A., Chen, B.X., Cleveland, W.L., Erlanger, B.F. (1992) Evidence for a functional receptor for cyclosporin A on the surface of lymphocytes. Proc Natl Acad Sci U S A 89, 4353-4357.

12. Shinozuka, H., Gill, T.J., III, Kunz, H.W., Witkowski, L.A., Demetris, A.J., Perera, M.I. (1986) Enhancement of the induction of murine thymic lymphomas by cyclosporine. Transplantation 41, 377-380.

13. Stewart, T., Tsai, S.C., Grayson, H., Henderson, R., Opelz, G. (1995) Incidence of de-novo breast cancer in women chronically immunosuppressed after organ transplantation. Lancet 346, 796-798.

14. Krajnc, E.I., Wester, P.W., Loeber, J.G., Van Leeuwen, F.X., Vos, J.G., Vaessen, H.A., Van der Heijden, C.A. (1984) Toxicity of bis(tri- $n$-butyltin)oxide in the rat. I. Short-term effects on general parameters and on the endocrine and lymphoid systems. Toxicol Appl Pharmacol 75, 363-386.

15. Vos, J.G., De Klerk, A., Krajnc, E.I., Kruizinga, W., Van Ommen, B., Rozing, J. (1984) Toxicity of bis(tri-nbutyltin)oxide in the rat. II. Suppression of thymus-dependent immune responses and of parameters of nonspecific resistance after short-term exposure. Toxicol Appl Pharmacol 75, 387-408.

16. Vos, J.G., De Klerk, A., Krajnc, E.I., Van Loveren, H., Rozing, J. (1990) Immunotoxicity of bis(tri- $n$ butyltin)oxide in the rat: effects on thymus-dependent immunity and on nonspecific resistance following longterm exposure in young versus aged rats. Toxicol Appl Pharmacol 105, 144-155.

17. Raffray, M., Cohen, G.M. (1993) Thymocyte apoptosis as a mechanism for tributyltin-induced thymic atrophy in vivo. Arch Toxicol 67, 231-236.

18. White, K.L., Kawabata, T.T., Ladics, G.S. (1994) Mechanisms of polycyclic aromatic hydrocarbon immunotoxicity. In: Immunotoxicology and Immunopharmacology (Dean JH, Luster MI, Munson AE, Kimber I Eds) 123-142. Raven Press Ltd, New York, USA.

19. De Jong, W.H., Kroese, E.D., Vos, J.G., Van Loveren, H. (1999) Detection of immunotoxicity of benzo[a]pyrene in a subacute toxicity study after oral exposure in rats. Toxicol Sci 50, 214-220.

20. Levin, W., Wood, A., Chang, R., Ryan, D., Thomas, P., Yagi, H., Thakker, D., Vyas, K., Boyd, C., Chu, S.Y., Conney, A., Jerina, D. (1982) Oxidative metabolism of polycyclic aromatic hydrocarbons to ultimate carcinogens. Drug Metab Rev 13, 555-580.

21. Stowers, S.J., Anderson, M.W. (1985) Formation and persistence of benzo(a)pyrene metabolite-DNA adducts. Environ Health Perspect 62, 31-39.

22. Ashby, J., Basketter, D.A., Paton, D., Kimber, I. (1995) Structure activity relationships in skin sensitization using the murine local lymph node assay. Toxicology 103, 177-194.

23. Woolhiser, M.R., Munson, A.E., Meade, B.J. (2000) Comparison of mouse strains using the local lymph node assay. Toxicology 146, 221-227.

24. Ravel, G., Christ, M., Horand, F., Descotes, J. (2004) Cytokine release does not improve the sensitivity and specificity of the direct popliteal lymph node assay. Toxicology $200,247-254$. 




\title{
3
}

\section{Gene expression profiling of} bis(tri-n-butyltin)oxide (TBTO) induced immunotoxicity in mice and rats

Journal of Immunotoxicology (2006) 3: 227-244

\author{
K.A. Baken ${ }^{1,2}$ \\ J.L.A. Pennings ${ }^{2}$ \\ A. de Vries $^{2}$ \\ T.M. Breit ${ }^{3}$ \\ H. van Steeg ${ }^{2,4}$ \\ H. van Loveren ${ }^{1,2}$
}

\footnotetext{
${ }^{1}$ Department of Health Risk Analysis and Toxicology, Maastricht University, Maastricht, The Netherlands ${ }^{2}$ Department of Toxicology, Pathology and Genetics, National Institute for Public Health and the Environment, Bilthoven, The Netherlands ${ }^{3}$ MicroArray Department (MAD), University of Amsterdam, Amsterdam, The Netherlands ${ }^{4}$ Department of Toxicogenetics, Leiden University Medical Center, Leiden, The Netherlands
} 


\title{
Chapter 3
}

\begin{abstract}
Bis(tri- $n$-butyltin)oxide (TBTO) is one of the organotin compounds that have been used as biocides and occur as persistent environmental pollutants. Human exposure to these compounds occurs through consumption of meat and fish products in which they accumulate. The most sensitive endpoint of TBTO exposure is immunotoxicity. TBTO causes thymus atrophy and thereby interferes with $T$ lymphocyte-mediated immune responses. Tributyltin compounds have been found to adversely affect a wide range of cellular components and processes in many species, organ systems, and cell types. Both inhibition of proliferation and induction of apoptosis have been observed in thymocytes. We conducted microarray experiments in mice and rats in order to investigate if the immunosuppressive actions of TBTO could be detected by gene expression profiling, and if so, to elucidate the mechanisms of action. Gene expression changes that were detected in mouse thymuses after exposure to a maximum tolerable dose of TBTO correlated to previously observed effects. Most notably, reduction of expression of cell surface determinants and $\mathrm{T}$ cell receptor chains, suppression of cell proliferation, and a possible involvement of nuclear receptors in interference with lipid metabolism by TBTO were observed. The TBTO-induced thymus involution may therefore primarily be caused by inhibition of thymocyte proliferation. In contrast, in rats only limited effects of a lower dose of TBTO were found at the gene expression level in the thymus, even though thymus involution was observed. Here, most gene expression regulation by TBTO was detected in the liver. These preliminary results indicate that gene expression analysis is able to reveal effects of TBTO and to gain insight into its molecular mechanism of action. It may even be a suitable tool to investigate immunotoxicology in general. However, dose and interspecies differences are apparently clearly reflected in the gene expression profiles.
\end{abstract}




\section{Introduction}

Bis(tri- $n$-butyltin)oxide (TBTO) is one of the organotin compounds that have been used as biocides, especially to control aquatic organisms, and occur as persistent environmental pollutants [1,2]. Food chain accumulation of tributyltin (TBT) has been shown in meat and fish products [2-6], human consumption of which is the most likely reason for detection of butyltin compounds in human blood and liver samples $[7,8]$. The first concerns about adverse effects of the tri-substituted organotin compounds arose when they were found to cause reproductive failure in oysters in the 1970ies [9]. A range of endocrine disrupting, developmental and reproductive effects in a variety of organisms have been detected since then [10-16]. TBTO was also found to stimulate development of tumors of endocrine origin $[8,17]$.

The most sensitive endpoint of acute TBTO exposure appears to be immunotoxicity $[18,19]$. In rats, TBTO causes thymus involution due to depletion of cortical thymocytes [20-23]. This results in peripheral depletion of $T$ lymphocytes and, as a consequence, a diminished cellular immune response which manifests itself in reduced delayed type hypersensitivity response, resistance to infections and antibody responses to $\mathrm{T}$ cell-dependent antigens [14,18,20,24-28]. TBT also affects non-specific immune functions like natural killer (NK) cell [28-33] and macrophage activity [19,34]. Furthermore, TBT was found to provoke T helper (Th)2 polarization in vitro and in vivo, as was indicated by suppression of production of Th1-related cytokines versus stimulation of Th2 cytokine production, and exacerbation of airway inflammation in an asthma model [35-37].

The toxicity of TBT compounds has been studied in numerous species, organ systems, and cell types and was explained in multiple ways [1,9,13,24]. TBT seems to be able to adversely affect a wide range of cellular components and processes. It is therefore not surprising that, in spite of the variety of studies on the toxic effects of TBTO, its molecular mechanism of action has still not been characterized fully. Whether the thymus atrophy observed after exposure to organotin compounds is primarily caused by antiproliferative effects $[21,38,39]$ or by induction of apoptosis [40-44] is, for instance, still unclear.

Since changes in gene expression often precede the molecular and cellular response of a biological system to a toxic insult, analysis of gene expression profiles accompanying exposure to TBTO could shed a new light on its effects. Microarray analysis provides the possibility to simultaneously determine the expression levels of thousands of genes after exposure to a toxicant. This approach (toxicogenomics) has contributed to the understanding of effects of various compounds in a variety of biological systems in recent years [45-47].

Only a few microarray experiments dealing with gene expression alterations induced by organotin compounds have been published so far. In the ascidian Ciona intestinalis, acute effects of exposure to TBT were assessed at the transcriptome level in the total body of three exposed and three control animals [48]. Up-regulation of stress response-related genes and increased expression of detoxification and oxidoreduction enzymes were detected. Genes encoding various proteins such as collagen, annexin, tubulin, mucin, fibronectin, and alcohol dehydrogenase were down-regulated. In TBTresistent bacteria, a low dose of TBT did not change gene expression profiles significantly. A higher dose mainly down-regulated translational and transcriptional processes [49]. The 
effects of dioctyltinchloride (DOTC) on the expression of apoptosis-related genes were tested in young male rats [50]. One to four days after oral administration of a high dose of this compound, thymus and spleen weights decreased, and more apoptotic cells were detected in both organs. However, down-regulation of at most three genes (Ahr, Casp3, and Txnll) and up-regulation of one gene (the nuclear receptor Nr3c1) were observed in the thymuses of these animals one day after DOTC administration.

We aimed to investigate if the immunosuppressive actions of TBTO would be detected using microarray analysis, and if so, to elucidate the mechanisms of action. Gene expression profiles were analyzed in the thymuses of mice orally exposed to a maximum tolerable dose of TBTO during various time periods. Since the immunotoxic effects of TBTO were originally studied in rats at lower doses $[14,17,19,28]$, we also studied changes in gene expression caused by TBTO in such an experimental setup. This study was extended with analysis of liver and spleen, in which toxic effects of TBTO have been observed as well [14,51], in order to compare gene expression profiles of other organs with those found in the primary target organ.

\section{Materials and Methods}

\section{Animals}

The experiments in mice were performed with 8 weeks old male C57BL/6Jlco mice from the institute's own breeding colony (originally obtained from Charles River, Sulzfeld, Germany). For the experiments in rats, male Wistar rats (HsdCpb:WU) obtained from Harlan (Horst, The Netherlands) were used at the age of 9 weeks. All animals were bred specific pathogen free and kept in macrolon cages under tightly controlled standardized conditions. The experimental setup of the studies was examined and agreed upon by the institute's Ethical Committee on Experimental Animals, according to national legislation.

\section{Oral TBTO exposure}

The experiment in mice included 48 animals which were randomly divided into two treatment groups. One group was fed pelleted control SRM-A food (supplied by Altromin, Lage, Germany), the other the same food mixed with TBTO (Sigma-Aldrich, Zwijndrecht, The Netherlands). The maximum tolerated dose (MTD) of TBTO for C57BL/6 mice, being a final concentration of $300 \mathrm{ppm}$ in food, was used with the intention of causing a $10 \%$ reduction in body weight gain along the growth curve compared to the control group. Each group was subdivided into three groups $(n=8)$ to which the diet was administered during 3 , 7 , or 14 days.

The 128 rats were randomly assigned to four treatment groups. The treatments consisted of administration of control food (powdered RM3 feed for rodents, supplied by TNO, Zeist, The Netherlands) or the same food mixed with TBTO (Sigma-Aldrich) at final concentrations of 5,20 , or $80 \mathrm{ppm}$. Each treatment group was divided into four subgroups $(n=8)$ that were fed the corresponding diet during 3, 7, 14, or 28 days. Food intake was monitored and the mean amount of TBTO consumed deviated on average $16 \%$, with one peak of $52 \%$, from the aimed exposure. 


\section{Dissection}

All mice and rats were sacrificed at the last day of the exposure period. The animals were euthanized by $\mathrm{CO}_{2} / \mathrm{O}_{2}$ exposure, weighed and exsanguinated. The thymus of each mouse was immediately collected in RNA stabilization reagent (RNAlater; Qiagen, Venlo, The Netherlands) and stored at $4{ }^{\circ} \mathrm{C}$ until further processing. The liver, spleen and thymus of each rat were weighed, snap frozen in liquid nitrogen and stored at $-80{ }^{\circ} \mathrm{C}$ until RNA isolation. Mesenteric lymph nodes of rats were also collected and weighed.

\section{RNA isolation and processing}

Total RNA was isolated using RNeasy midi kits (Qiagen) with an additional DNase treatment (RNase-Free DNase Set; Qiagen) according to the manufacturer's instructions. To start the procedure, the mouse thymuses were placed in lysis buffer and disrupted and homogenized immediately using a rotor-stator homogenizer (Diax 900 10G, Heidolph, Schwabach, Germany). The frozen organs of rats were split in a liquid nitrogen-cooled mortar, after which a small piece was placed in the lysis buffer and homogenized similarly to the mouse organs. The quantity of RNA in each sample was assessed spectrophotometrically (ND1000; NanoDrop Technologies, Wilmington, USA) and RNA integrity was determined by automated gel electrophoresis (Bioanalyzer 2100; Agilent Technologies, Amstelveen, The Netherlands).

The mouse RNA samples were precipitated by addition of 0.1 volumes of sodium acetate and 3 volumes of absolute ethanol for storage at $-80^{\circ} \mathrm{C}$. Shortly before microarray analysis, the samples were centrifuged (45 $\min 14000 \mathrm{rpm}, 4^{\circ} \mathrm{C}$ ) and the supernatants removed. Then the pellets were washed with $70 \%$ ethanol and resuspended in an amount of RNase free water (Qiagen) to obtain an RNA concentration of $2.5 \mu \mathrm{g} / \mu \mathrm{l}$. For each exposure group, 4 pooled RNA samples consisting of $10 \mu \mathrm{g}$ RNA of each of 2 individual samples were composed for further analysis. In this study, a reference pool of mouse embryo RNA that was prepared similarly to the RNA samples was used.

The concentration of all rat RNA samples was adjusted to $2.5 \mu \mathrm{g} / \mu \mathrm{l}$ by vacuum drying (SpeedVac Sc110 with Refrigerated Condensation Trap Rt100; Savant, Thermo Electro Corporation, Breda, The Netherlands) and addition of RNase free water. A common reference pool was prepared by mixing equal volumes of all RNA samples of each organ and treatment group. All rat RNA samples were stored at $-80{ }^{\circ} \mathrm{C}$ until microarray analysis. For further analysis, 5 out of the 8 RNA samples of each subgroup were selected based on RNA yield and quality.

\section{Labeling}

Microarray analyses of the mouse RNA samples were conducted at the MicroArray Department (MAD) of the University of Amsterdam (UvA, The Netherlands) according to standard procedures. In short, RNA was amplified using a commercial amplification kit (Amino Allyl MessageAmp RNA kit, Ambion, Austin, USA). Labeling was performed with an indirect labeling method (Cyscribe Post Labeling kit, CyDye Post Labeling Reactive Dye Pack and Cyscribe GFX Purification kit; Amersham Biosciences, Buckinghamshire, UK), according to the manufacturer's instructions. Cy3 was used to label $3 \mu \mathrm{g}$ of sample 
aRNA, and equal aliquots of reference pool aRNA were labeled with Cy5 simultaneously. Then $150 \mathrm{pmol}$ of labeled sample and $75 \mathrm{pmol}$ of reference pool were both reduced to $9 \mu \mathrm{l}$ by vacuum drying, after which the aRNA was fragmented (RNA Fragmentation Reagents; Ambion). Then the volumes of the (reference) samples were adjusted to $26 \mu \mathrm{l}$ with milliQ, and $1 \mu \mathrm{l}$ was used to examine quality using the Bioanalyzer. Finally, every sample was combined with a reference pool sample.

The procedure for rat RNA labeling was comparable to that for the mouse, except for lack of the amplification step, cDNA synthesis of $20 \mu \mathrm{g}$ of total RNA of sample and reference pool, labeling of samples with Cy5 and reference pool with Cy3, usage of all labeled material for hybridization, and absence of a fragmentation step.

\section{Hybridization}

The mouse experiment was performed using a Mouse Sigma Compugen oligolibrary consisting of a selection of $11 \mathrm{~K}$ genes with a bias towards immunological and toxicological relevance in duplicate. After spotting, the slides were put in hot steam shortly and dried. Then the oligos were cross-linked by $150 \mathrm{~mJ}$ UV light. Just before hybridization of aRNA, the slides were prehybridized in $2 x$ SSPE/0.2\% SDS (both Ambion) at $52{ }^{\circ} \mathrm{C}$ for $2 \mathrm{~h}$. To the $50 \mu \mathrm{l}$ of combined sample and reference pool, $50 \mu \mathrm{l}$ microarray hybridization mixture (Amersham) was added. Then $100 \mu \mathrm{l}$ of formamide (Sigma-Aldrich) was added and the samples were injected into the hybridization chamber of an automated slide processor (Lucidea SlidePro Hybridizer; Amersham). Sixteen $\mathrm{h}$ of incubation at $37^{\circ} \mathrm{C}$ were followed by $10 \mathrm{~min}$ of washing in $1 \times$ SSC/0.2\% SDS, $10 \mathrm{~min}$ in $0.1 \times \mathrm{SSC} / 0.2 \% \mathrm{SDS}$, and $4 \mathrm{~min}$ in $0.1 \%$ SSC. Finally, slides were flushed with milliQ and isopropanol (Sigma-Aldrich).

For the rat experiment, the Rat Array Ready Oligo Set v1.0 (Operon Biotechnologies $\mathrm{GmbH}$, Cologne, Germany) containing 5,705 C6-amino-linked oligos representing rat genes was spotted in duplicate on silylated glass slides at the University Medical Centre Utrecht (UMC, The Netherlands). Pre-treatment of the slides included successive washing in a $0.2 \%$ SDS solution, milliQ, $0.25 \mathrm{~g}$ of sodiumborohydride (SigmaAldrich) in $75 \mathrm{ml}$ phosphate buffered saline and $25 \mathrm{ml}$ ethanol, and $0.2 \%$ SDS and milliQ again. Slides were dried quickly and evenly by centrifugation at $1000 \mathrm{rpm}$ and stored in a dark moisture- and dust-free exsicator until further use. The rat slides were prehybridized at $42{ }^{\circ} \mathrm{C}$ for at least one hour in $5 x$ SSC (Invitrogen, Breda, The Netherlands), $0.1 \%$ SDS and $1 \%$ BSA (Sigma-Aldrich) dissolved in milliQ and sterilized by filtering through a 0.22 micron filter (Millipore, Amsterdam, The Netherlands). Just before hybridization, the slides were washed in milliQ and propanol and dried by centrifugation. Rat hybridization mixture consisted of $50 \%$ formamide, $10 x$ SSC, and $0.2 \%$ SDS, which was filtered through a 0.22 micron filter and preheated to $42{ }^{\circ} \mathrm{C}$. Then $50 \mu \mathrm{g}$ salmon sperm (Gibco, Invitrogen) and 1.3 pmol of a Cy3-labeled 70-mer oligo complementary to a landmark control oligo [52] (Operon) were added to $250 \mu \mathrm{l}$ of the mixture. Of this hybridization mixture, $25 \mu \mathrm{l}$ was added to each $25 \mu \mathrm{l}$ of combined sample and reference cDNA, and the complete mixture was heated at $95{ }^{\circ} \mathrm{C}$ for $5 \mathrm{~min}$. Finally, $45 \mu \mathrm{l}$ of the cDNA mixture was pipetted onto the glass slide and spread evenly by application of a cover slip. This was incubated for $18 \mathrm{~h}$ at $42{ }^{\circ} \mathrm{C}$ in the dark in humid hybridization chambers (GeneMachines Genomic Solutions Ltd., Cambridgeshire, UK). Thereafter, slides were washed successively in 2x SSC/0.1\% 
SDS (5 min $42{ }^{\circ} \mathrm{C}$, twice), $0.1 \times \mathrm{SSC} / 0.1 \% \operatorname{SDS}(5 \mathrm{~min})$ and $0.1 \times \mathrm{SSC}$ ( $1 \mathrm{~min}$, twice) with milliQ as vehicle.

\section{Scanning}

Immediately after drying, mouse slides were scanned using the Agilent G2565 microarray scanner. The rat microarray slides were scanned randomly using the Scanarray $4000 \mathrm{XL}$ (Perkin Elmer, Boston, USA) with appropriate laser and photo multiplier tube (PMT) settings. Array Vision software (Imaging Research, St. Catherines, Ontario, Canada) was used to determine Cy3 and Cy5 signal intensities for each separate spot and background noise. Quality control was performed on raw data by means of a scatter plot and MA-plot as well as a normal probability plot to assess signal distribution [53]. All slides contained appropriate controls and blank spots, which were used for quality control but not included in further analyses.

\section{Statistics}

Significance of differences of absolute and relative (corrected for body weight) rat organ weights between groups was determined with ANOVA using SPSS for Windows.

Raw microarray signal data were normalized in R (http://www.r-project.org) using a four-step approach of (1) natural log-transformation (2) quantile normalization of all scans (3) correcting the sample spot signal for differences in the corresponding reference spot signal between arrays (4) averaging data from replicate spots. This method is essentially comparable to global LOESS normalization. Then the data were analyzed by Principal Component Analysis (PCA) using GeneMaths (Applied Maths, St-MartensLatem, Belgium). Significance of differences in gene expression between the experimental groups was calculated in R with ANOVA. The false discovery rate (FDR) was calculated per gene according to Benjamini and Hochberg [54]. For each gene maximal fold ratios (FRs) in gene expression between the experimental groups were determined by comparing the average normalized signal values per group and were calculated as the maximum/minimum ratio. FDR and FR criteria were fixed to levels suitable for further analysis. Differentially expressed genes were clustered (based on Euclidian Distance and Ward linkage) using GeneMaths. Gene Ontology (GO) term enrichment was investigated with the Expression Analysis Systematic Explorer (EASE, http://david.abcc.ncifcrf.gov/ease/ease.jsp) using a maximal FDR of 0.1. MetaCore from GeneGo Inc. (http://www.genego.com) was used to identify and visualize the involvement of the differentially expressed genes in specific cellular pathways.

\section{Real time RT-PCR}

Expression levels of four genes in all mouse samples and three genes in the rat samples used for microarray analysis were measured by means of real time RT-PCR. All reagents and equipment were obtained from Applied Biosystems (Foster City, USA). The following TaqMan Gene Expression Assays were used: Mm00432648_m1 (Cox8b), Mm00432403_m1 (CD36), Mm00493500_m1 (Dntt), Mm00448717_m1 (Sh2d1a), Rn00589996_m1 (Cdkn1a), Rn00564065_m1 (Cyp7a1), and Rn00595671_m1 (Nr1d1). 
Assays for HPRT and RP2 were custom made and included as endogenous controls. Presence of genomic DNA in RNA samples and amplification efficiency for all assays were assessed before the start of the measurements. RNA was converted to cDNA using the High-Capacity cDNA Archive Kit according to the manufacturer's instructions. For each measured gene, $1 \mu \mathrm{l}$ assay was mixed with $10 \mu \mathrm{l}$ TaqMan Fast Universal PCR Master mix and added to $50 \mathrm{ng}$ of every cDNA sample in $9 \mu \mathrm{l}$ milliQ in duplicate. The cDNA was amplified in a 96-well plate during 40 cycles of $3 \mathrm{sec}$ at $95{ }^{\circ} \mathrm{C}$ and $30 \mathrm{sec}$ at $60{ }^{\circ} \mathrm{C}$, preceded by $20 \mathrm{sec}$ at $95{ }^{\circ} \mathrm{C}$ for enzyme activation, using the 7500 Fast Real-Time PCR System. No template controls (NTC) were included in all plates. Threshold cycles (Ct) were automatically derived from the amplification plots constructed of the ROX-normalized fluorescence signals by 7500 Fast System SDS Software v1.3. The expression levels of the endogenous controls were comparable to each other and for all samples. The mean of the HPRT and RP2 levels of all samples were therefore used to normalize the expression of the other genes. Relative quantification of the mRNA copies in the TBTO exposed samples compared to controls was performed by the comparative $\mathrm{Ct}$ method (ddCt) using Microsoft Excel. 


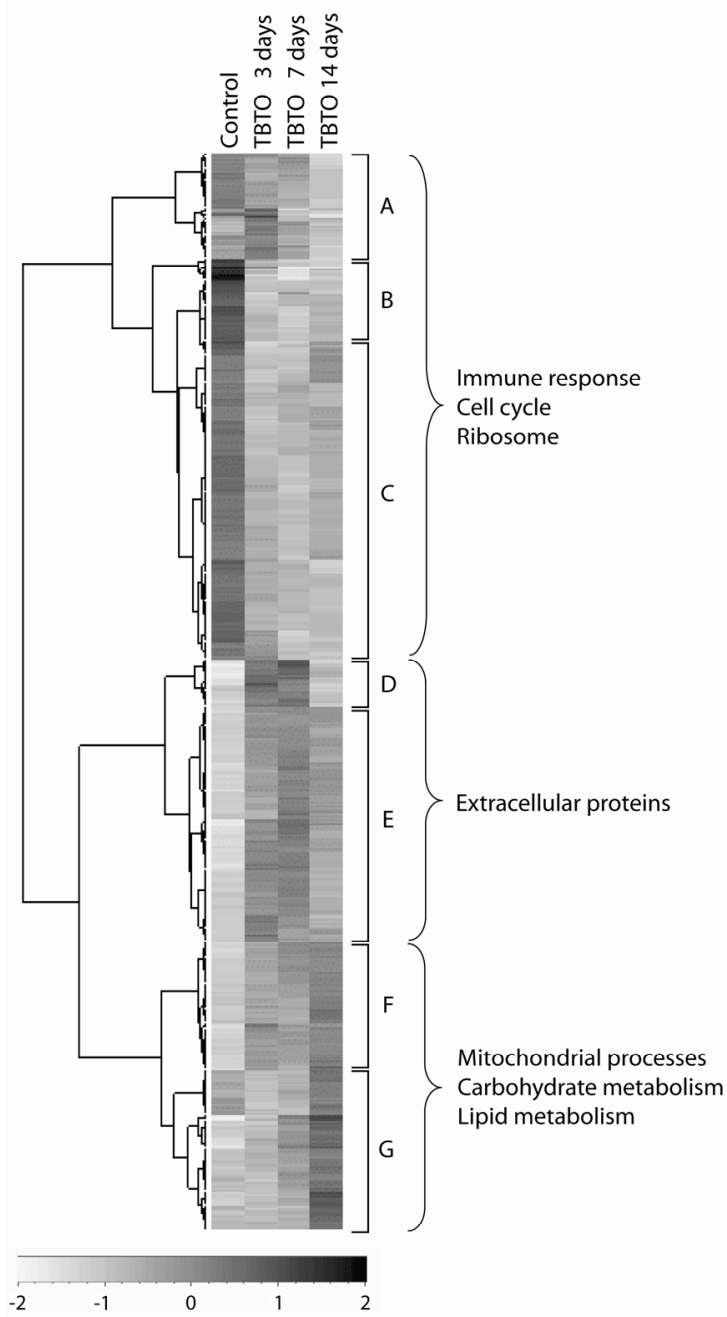

\section{Figure 1.}

Clustering of the 703 differentially regulated (FDR $<0.05$ and FR $\leq-2$ or $\geq 2$ ) oligos in thymuses of C57BL/6 mice after exposure to 300 ppm TBTO in the diet for 3,7 , or 14 days. Per exposure group or time-matched control group, 4 pools of 2 RNA samples of mouse thymuses were analyzed using microarrays comprising $11 \mathrm{~K}$ oligos with immunological or toxicological relevance spotted in duplicate. Gene expression levels are indicated by the bar and relative In values: white represents downregulation and black up-regulation. Roughly, seven categories can be discriminated based on gene expression levels, which are referred to as: A. late down-regulation; B. constant down-regulation; C. early down-regulation; D. temporary up-regulation; E. early up-regulation; F. gradual up-regulation; G. late up-regulation. Gene Ontology term enrichment (FDR <0.1) was determined for all regulated genes and the groups of down-regulated (A-C), early up-regulated (D-E), and gradually up-regulated (F-G) genes. The affected biological pathways and cellular components are shown beside the corresponding clusters. 


\section{Results}

\section{Analysis of TBTO-induced immunotoxicity in mice}

\section{ANIMAL WEIGHTS AND MACROSCOPY}

The growth of the TBTO-exposed mice lagged 16,25 , and $26 \%$ behind the controls at 3 , 7 , and 14 days after the start of TBTO administration, respectively (data not shown). Thymus weights were not assessed, but from 3 days of TBTO exposure onward, a severe time-dependent involution of mouse thymuses was observed macroscopically.

\section{GENE EXPRESSION ANALYSIS}

All microarray hybridizations in this experiment met our quality requirements and were included in the analysis. The different exposure groups could be discriminated by PCA. The average expression levels in the three time-matched control groups were, as expected, not significantly different (data not shown), and therefore data of all control samples were pooled. ANOVA on the gene expression data of the three TBTO exposed groups and the control pool yielded 5,668 differently expressed oligos with a FDR of 0.05 or lower. When a maximal FR of $\leq-2$ or $\geq 2$ between any two groups was applied to select oligos that were differentially regulated by TBTO, 703 hits were found, 519 of which could be annotated according to the current NCBI databases (http://www.ncbi.nlm.nih.gov/). The largest part of the remaining oligos was derived from GenBank rearranged $\mathrm{T}$ cell receptor chain sequences, or represented immunoglobulin chains.

The expression levels of two of the most strongly up-regulated genes (Cox8b and CD36) and two of the most strongly down-regulated genes (Dntt and Sh2d1a) were determined by real time RT-PCR. All gene expression patterns matched and thereby confirmed the microarray results (data not shown).

\section{CLUSTERING AND PATHWAY ANALYSIS}

Figure 1 shows the clustering of all hits. TBTO-induced gene expression changes were detected already after 3 days of exposure. Broadly, seven categories of gene regulation can be distinguished, which are referred to as: A. late down-regulation; B. constant downregulation; C. early down-regulation; $D$. temporary up-regulation; E. early up-regulation; $F$. gradual up-regulation; $\mathrm{G}$. late up-regulation. Almost all $\mathrm{T}$ cell receptor chain oligos were found in cluster $C$ and the remaining part in cluster $A$ and $B$, whereas the great majority of immunoglobulin chains were spread over clusters $E, F$, and $G$.

Analysis of GO term enrichment in all 519 annotated hits showed that a significantly large proportion of these oligos represent cell surface determinants and other genes that function in immune cell activation and the immune response in general. These genes and their FRs are displayed in Table 1. If cluster A, B and C, being predominantly down-regulated genes, were examined jointly, enrichment of immune-related genes was found again, and in addition the cell cycle and related processes such as DNA replication, cell division and mitosis as well as genes encoding ribosomal proteins appeared to be affected. Table 2 shows the corresponding genes and FRs. Cluster D and E contain genes that are most strongly up-regulated at the first and especially the second time point, and 
together showed enrichment of genes representing extracellular proteins only (Table 3). Finally, in cluster $F$ and $G$, representing genes that are up-regulated time-dependently, TBTO primarily affected mitochondrial functioning, including electron transport and cytochrome c activity, as well as carbohydrate and lipid metabolism. Genes that take part in these processes are displayed in Table 4. Since the immune response was not affected significantly in the subsets of up-regulated genes, genes involved in the immune response of which the expression was induced by TBTO are not shown in Table 3 and 4.

An additional analysis of affected cellular pathways was conducted using MetaCore. The process in which in general the largest part of the hits took part (as compared to the amount of genes involved in the particular pathway and in all the available pathways together) was the cell cycle. Other processes with a high ranking were metabolism of diverse substrates, growth and differentiation, cell death, and cell adhesion. The two most clearly affected MetaCore pathways concerned the start of DNA replication in the early $S$ phase and cell cycle regulation by the anaphase-promoting complex (APC) (Figure $2 \mathrm{a}$ and $2 \mathrm{~b}$, respectively). Differentially expressed genes involved in these pathways were predominantly down-regulated. Furthermore, clear gene regulation in lipid metabolism pathways was found. The most significantly affected pathway of those showed that three genes of which the transcription is induced after dimerization of RXR with PPARy and that regulate $\beta$-oxidation of fatty acids (Fabp, CD36, and acyl-coa synthetase), were up-regulated in our data set.

Another pathway that involved a large part of the hits showed that CD28 signaling was repressed by down-regulation of several genes that code for involved proteins (Itk, Lat, SIp76, and Vav1) and up-regulation of CD86, which binds CD28 and can both stimulate and inhibit T cell activation. CD28 is involved in T cell activation, the induction of cell proliferation and cytokine production, and promotion of T cell survival. Some other pathways containing a high amount of the differentially expressed genes were involved in nucleotide metabolism (down-regulation), the citric acid cycle (late up-regulation), oxidative phosphorylation (mainly up-regulation), and cyclin functioning (down-regulation). 
Table 1.

Genes that contribute to the enrichment of the Gene Ontology term 'Immune response' in all differentially regulated genes (clusters A-G) by TBTO in mouse thymuses.

\begin{tabular}{|c|c|c|c|c|c|}
\hline \multirow[t]{2}{*}{ GenBank } & \multirow[t]{2}{*}{ Symbol } & \multirow[t]{2}{*}{ Gene name } & \multicolumn{3}{|c|}{ FR } \\
\hline & & & $3 \mathrm{~d}$ & $7 \mathrm{~d}$ & $14 \mathrm{~d}$ \\
\hline & & Immune response & & & \\
\hline NM_016707 & $\mathrm{Bcl} 11 \mathrm{a}$ & B cell CLL/lymphoma 11A (zinc finger protein) & 2.0 & 2.3 & 1.9 \\
\hline NM_013484 & $\mathrm{C} 2$ & complement component 2 (within $\mathrm{H}-2 \mathrm{~S}$ ) & 3.1 & 3.3 & 2.0 \\
\hline NM_011124 & Ccl21b & chemokine ( $\mathrm{C}-\mathrm{C}$ motif) ligand $21 \mathrm{~b}$ (serine) & 1.5 & 1.6 & 2.1 \\
\hline NM_019388 & Cd86 & CD86 antigen & 2.7 & 2.0 & 1.2 \\
\hline NM_009883 & Cebpb & CCAAT/enhancer binding protein (C/EBP), beta & 1.5 & 2.0 & 2.4 \\
\hline NM_020008 & Clec7a & C-type lectin domain family 7, member a & 4.6 & 7.0 & 2.1 \\
\hline NM_010188 & Fcgr3 & Fc receptor, IgG, low affinity III & 3.8 & 5.8 & 1.4 \\
\hline NM_023145 & $\mathrm{H} 2-\mathrm{Aa}$ & histocompatibility 2 , class II antigen $\mathrm{A}$, alpha & 3.4 & 2.2 & 2.4 \\
\hline NM_013819 & H2-M3 & histocompatibility 2, M region locus 3 & 1.4 & 1.2 & 2.2 \\
\hline U89889 & Hpxn & hemopexin & 1.5 & 2.3 & 2.9 \\
\hline AK003407 & Ifitm3 & interferon induced transmembrane protein 3 & 4.5 & 4.2 & 1.7 \\
\hline NM_010549 & II11ra1 & interleukin 11 receptor, alpha chain 1 & 2.4 & 1.9 & 1.6 \\
\hline AF235006 & II24 & interleukin 24 & 1.1 & 1.6 & 2.9 \\
\hline NM_008455 & Klkb1 & kallikrein B, plasma 1 & 2.0 & 1.6 & 2.7 \\
\hline NM_011146 & Pparg & peroxisome proliferator activated receptor gamma & -1.3 & 1.3 & 2.1 \\
\hline NM_011189 & Psme1 & proteasome (prosome, macropain) 28 subunit, alpha & 2.4 & 2.8 & 1.0 \\
\hline NM_011315 & Saa3 & serum amyloid $A 3$ & 2.8 & 2.3 & 1.2 \\
\hline NM_013683 & Tap1 & $\begin{array}{l}\text { transporter } 1 \text {, ATP-binding cassette, sub-family B } \\
\text { (MDR/TAP) }\end{array}$ & 1.4 & 1.9 & 2.2 \\
\hline NM_011609 & Tnfrsf1a & tumor necrosis factor receptor superfamily member & 2.0 & 2.6 & 1.6 \\
\hline NM_023517 & Tnfsf13 & tumor necrosis factor (ligand) superfamily member 13 & 2.1 & 1.7 & 1.9 \\
\hline NM_029509 & 5830443L24Ri & RIKEN cDNA 5830443L24 gene * & -2.5 & -3.3 & -2.5 \\
\hline NM_013653 & $\mathrm{Ccl} 5$ & chemokine ( $\mathrm{C}-\mathrm{C}$ motif) ligand 5 * & -2.0 & -1.7 & -2.0 \\
\hline NM_007632 & Ccnd3 & cyclin D3 * & -3.3 & -5.0 & -3.3 \\
\hline NM_007987 & Fas & Fas (TNF receptor superfamily member) ${ }^{*}$ & -3.3 & -5.0 & -5.0 \\
\hline K01925 & $\mathrm{H} 2-\mathrm{Aa}$ & histocompatibility 2 , class II antigen A, alpha * & -2.0 & -3.3 & -2.0 \\
\hline NM_010379 & $\mathrm{H} 2-\mathrm{Ab} 1$ & histocompatibility 2 , class II antigen A, beta $1^{*}$ & -3.3 & -5.0 & -3.3 \\
\hline$\times 57330$ & $\mathrm{H} 2-\mathrm{Q} 7$ & histocompatibility $2, \mathrm{Q}$ region locus $7^{*}$ & 1.6 & 1.1 & -1.3 \\
\hline AF052834 & Igh-6 & immunoglobulin heavy chain 6 (heavy chain of $\lg M)$ * & -5.0 & -5.0 & -2.5 \\
\hline NM_010689 & Lat & linker for activation of $\mathrm{T}$ cells * & -2.5 & -5.0 & -5.0 \\
\hline NM_010696 & Lcp2 & lymphocyte cytosolic protein 2 * & -1.4 & -2.5 & -2.5 \\
\hline NM_008859 & Prkcq & protein kinase $\mathrm{C}$, theta * & -2.5 & -3.3 & -2.5 \\
\hline NM_011196 & Ptger3 & prostaglandin E receptor 3 (subtype EP3) * & -1.4 & -1.7 & -2.0 \\
\hline NM_009020 & Rag2 & recombination activating gene 2 * & 1.2 & -1.4 & -1.7 \\
\hline NM_011364 & Sh2d1a & $\mathrm{SH} 2$ domain protein $1 \mathrm{~A}^{*}$ & -10.0 & -10.0 & - \\
\hline X00439 & Tcrb & T cell receptor beta chain * & 1.5 & -1.7 & $-\hat{1} \hat{7}$ \\
\hline L24495 & Tnfrsf7 & tumor necrosis factor receptor superfamily member 7 & -2.0 & -2.5 & -2.0 \\
\hline NM_011691 & Vav1 & vav 1 oncogene * & -2.5 & -5.0 & -2.5 \\
\hline
\end{tabular}

* Also contributing to enrichment of the Gene Ontology term 'Immune response' in the subgroup of downregulated genes (cluster A-B-C) (Table 2).

C57BL/6 mice were exposed to 0 or $300 \mathrm{ppm}$ TBTO in the diet during 3,7 , or 14 days $(n=8)$, where after microarray analysis was performed in the thymuses. Criteria for differential gene expression were FDR $<0.05$ and maximal FR between any two groups $\leq-2$ or $\geq 2$. Significant enrichment (FDR $<0.1$ ) of Gene Ontology terms was determined for specific groups of genes selected by hierarchical clustering. The FRs for the corresponding genes are displayed as compared to the control group. 
Table 2.

Genes that contribute to the enrichment of the Gene Ontology terms 'Immune response', 'Cell cycle', and 'Ribosome' in down-regulated genes (clusters A-B-C) by TBTO in mouse thymuses.

\begin{tabular}{|c|c|c|c|c|c|}
\hline \multirow[t]{2}{*}{ GenBank } & \multirow[t]{2}{*}{ Symbol } & \multirow[t]{2}{*}{ Gene name } & \multicolumn{3}{|c|}{ FR } \\
\hline & & & $3 \mathrm{~d}$ & $7 \mathrm{~d}$ & $14 \mathrm{~d}$ \\
\hline & & Immune response & & & \\
\hline & & See Table $1\left(^{*}\right)$ & & & \\
\hline & & Cell cycle & & & \\
\hline AF002823 & Bub1 & $\begin{array}{l}\text { budding uninhibited by benzimidazoles } 1 \text { homolog } \\
\text { (S. cerevisiae) }\end{array}$ & -2.5 & -2.5 & -2.0 \\
\hline NM_009773 & Bub1b & $\begin{array}{l}\text { budding uninhibited by benzimidazoles } 1 \text { homolog, beta } \\
\text { (S. cerevisiae) }\end{array}$ & -3.3 & -2.5 & -2.5 \\
\hline NM_007589 & Calm2 & calmodulin 2 & -2.0 & -2.5 & -1.3 \\
\hline NM_009828 & Ccna2 & cyclin A2 & -2.0 & -2.0 & -3.3 \\
\hline NM_007629 & Ccnb1 & cyclin B1 & -3.3 & -2.5 & -3.3 \\
\hline NM_007630 & Ccnb2 & cyclin B2 & -5.0 & -5.0 & -5.0 \\
\hline NM_009829 & Ccnd2 & cyclin D2 & -2.5 & -2.5 & -1.7 \\
\hline NM_007632 & Ccnd3 & cyclin D3 & -3.3 & -5.0 & -3.3 \\
\hline NM_007635 & Ccng2 & cyclin G2 & -2.5 & -3.3 & -5.0 \\
\hline AF011644 & Cdk2ap1 & CDK2 (cyclin-dependent kinase 2)-associated protein 1 & -2.5 & -1.7 & -1.7 \\
\hline NM_007671 & Cdkn2c & cyclin-dependent kinase inhibitor $2 \mathrm{C}(\mathrm{p} 18$, inhibits CDK4) & -2.0 & -2.0 & -1.1 \\
\hline NM_016904 & Cks1b & CDC28 protein kinase $1 \mathrm{~b}$ & -3.3 & -3.3 & -2.5 \\
\hline NM_009584 & Dnajc2 & DnaJ (Hsp40) homolog, subfamily C, member 2 & 1.8 & 1.1 & -1.7 \\
\hline NM_020567 & Gmnn & geminin & -2.5 & -2.5 & -2.5 \\
\hline NM_016692 & Incenp & inner centromere protein & -1.7 & -1.7 & -2.5 \\
\hline NM_011919 & Ing1 & inhibitor of growth family, member 1 & -2.0 & -2.0 & -1.1 \\
\hline S74567 & Maf & $\begin{array}{l}\text { avian musculoaponeurotic fibrosarcoma (v-maf) AS42 } \\
\text { oncogene homolog }\end{array}$ & 1.6 & 1.0 & -1.7 \\
\hline NM_008564 & Mcm2 & $\begin{array}{l}\text { minichromosome maintenance deficient } 2 \text { mitotin } \\
\text { (S. cerevisiae) }\end{array}$ & -3.3 & -2.5 & -2.5 \\
\hline X62154 & Mcm3 & minichromosome maintenance deficient 3 (S. cerevisiae) & -2.0 & -2.0 & -2.5 \\
\hline NM_008566 & Mcm5 & $\begin{array}{l}\text { minichromosome maintenance deficient } 5 \text {, cell division } \\
\text { cycle } 46 \text { (S. cerevisiae) }\end{array}$ & -2.5 & -2.0 & -2.5 \\
\hline X82786 & Mki67 & antigen identified by monoclonal antibody Ki 67 & -5.0 & -5.0 & -3.3 \\
\hline M16449 & Myb & myeloblastosis oncogene & 2.1 & -1.3 & -1.7 \\
\hline NM_009538 & Plagl1 & pleiomorphic adenoma gene-like 1 & 2.3 & 1.5 & 1.1 \\
\hline D90225 & Ptn & pleiotrophin & -2.5 & -1.7 & -1.3 \\
\hline NM_009009 & Rad21 & RAD21 homolog (S. pombe) & -2.5 & -2.5 & -1.7 \\
\hline NM_016758 & Rgs14 & regulator of G-protein signaling 14 & -2.0 & -3.3 & -2.5 \\
\hline NM_011379 & Sipa1 & signal-induced proliferation associated gene 1 & -1.7 & -1.4 & -2.0 \\
\hline NM_013787 & Skp2 & S-phase kinase-associated protein 2 ( $\mathrm{p} 45)$ & -2.5 & -2.0 & -1.7 \\
\hline NM_012046 & Spo11 & $\begin{array}{l}\text { sporulation protein, meiosis-specific, SPO11 homolog } \\
\text { (S. cerevisiae) }\end{array}$ & 1.0 & -2.0 & -2.0 \\
\hline NM_021465 & Stag2 & stromal antigen 2 & -1.4 & -1.7 & -2.0 \\
\hline NM_011524 & Tacc3 & transforming, acidic coiled-coil containing protein 3 & -2.5 & -2.5 & -2.5 \\
\hline NM_011655 & Tubb5 & tubulin, beta 5 & -2.0 & -1.7 & -2.5 \\
\hline \multirow[t]{2}{*}{ NM_011691 } & Vav1 & vav 1 oncogene & -2.5 & -5.0 & -2.5 \\
\hline & & Ribosome & & & \\
\hline NM_009009 & Rad21 & RAD21 homolog (S. pombe) & -2.5 & -2.5 & -1.7 \\
\hline NM_009078 & Rpl19 & ribosomal protein L19 & -2.5 & -2.0 & -2.5 \\
\hline NM_011291 & Rpl7 & ribosomal protein L7 & -1.4 & -1.7 & -2.0 \\
\hline NM_012053 & Rpl8 & ribosomal protein L8 & -2.0 & -2.0 & -2.5 \\
\hline U93864 & Rps11 & ribosomal protein $\mathrm{S} 11$ & -1.4 & 1.0 & -2.5 \\
\hline NM_013647 & Rps16 & ribosomal protein S16 & -1.3 & -1.7 & -2.0 \\
\hline NM_016959 & Rps3a & ribosomal protein S3a & 1.5 & 1.1 & -1.7 \\
\hline NM_011300 & Rps7 & ribosomal protein S7 & 1.5 & 1.4 & -2.0 \\
\hline
\end{tabular}

For experimental design, see Table 1. 
Table 3.

Genes that contribute to the Gene Ontology term 'Extracellular proteins' in early up-regulated genes (clusters D-E) by TBTO in mouse thymuses.

\begin{tabular}{|c|c|c|c|c|c|}
\hline \multirow[t]{2}{*}{ GenBank } & \multirow[t]{2}{*}{ Symbol } & \multirow[t]{2}{*}{ Gene name } & \multicolumn{3}{|c|}{ FR } \\
\hline & & & $3 d$ & $7 \mathrm{~d}$ & $14 \mathrm{~d}$ \\
\hline & & Extracellular proteins & & & \\
\hline NM_009616 & Adam19 & $\begin{array}{l}\text { a disintegrin and metalloproteinase domain } 19 \text { (meltrin } \\
\text { beta) }\end{array}$ & 1.9 & 2.3 & 1.4 \\
\hline NM_021475 & Adamdec1 & ADAM-like, decysin 1 & 1.7 & 2.5 & 1.9 \\
\hline NM_011318 & Apcs & serum amyloid P-component & 1.8 & 2.5 & 1.8 \\
\hline NM_009465 & Axl & AXL receptor tyrosine kinase & 2.1 & 2.3 & 1.3 \\
\hline NM_007542 & Bgn & biglycan & 2.3 & 3.2 & 2.6 \\
\hline NM_013484 & $\mathrm{C} 2$ & complement component 2 (within $\mathrm{H}-2 \mathrm{~S}$ ) & 3.1 & 3.3 & 2.0 \\
\hline NM_009807 & Casp1 & caspase 1 & 2.1 & 2.6 & 1.6 \\
\hline NM_007662 & Cdh15 & cadherin 15 & 2.4 & 2.4 & 2.1 \\
\hline NM_007663 & Cdh16 & cadherin 16 & 1.8 & 2.1 & 1.4 \\
\hline NM_007728 & Coch & coagulation factor $\mathrm{C}$ homolog (Limulus polyphemus) & 1.9 & 2.1 & 1.4 \\
\hline D17546 & Col18a1 & procollagen, type XVIII, alpha 1 & 1.8 & 3.0 & 2.1 \\
\hline NM_009933 & Col6a1 & procollagen, type $\mathrm{VI}$, alpha 1 & 2.8 & 3.4 & 1.9 \\
\hline AF064749 & Col6a3 & procollagen, type $\mathrm{VI}$, alpha 3 & 2.4 & 3.1 & 1.9 \\
\hline AF237721 & Col9a3 & procollagen, type IX, alpha 3 & 2.6 & 3.0 & 1.8 \\
\hline NM 007851 & Defcr5 & defensin related cryptdin 5 & 2.0 & 2.1 & 1.5 \\
\hline NM_007894 & Ear1 & eosinophil-associated, ribonuclease A family, member 1 & 2.5 & 2.1 & 1.4 \\
\hline NM_021474 & Efemp2 & $\begin{array}{l}\text { epidermal growth factor-containing fibulin-like extracellular } \\
\text { matrix protein } 2\end{array}$ & 3.0 & 3.3 & 2.2 \\
\hline Z49086 & Ephb3 & Eph receptor B3 & 2.5 & 2.5 & 1.5 \\
\hline NM_021489 & F12 & coagulation factor XII (Hageman factor) & 1.8 & 2.2 & 1.5 \\
\hline NM_007993 & Fbn1 & fibrillin 1 & 2.6 & 3.2 & 2.2 \\
\hline NM_010222 & Fkbp7 & FK506 binding protein 7 & 2.8 & 3.1 & 1.8 \\
\hline NM_010280 & Gfra3 & $\begin{array}{l}\text { glial cell line derived neurotrophic factor family receptor } \\
\text { alpha } 3\end{array}$ & 2.0 & 2.0 & 1.7 \\
\hline NM_008318 & lbsp & integrin binding sialoprotein & 2.2 & 2.6 & 1.5 \\
\hline AF296282 & Icam4 & $\begin{array}{l}\text { intercellular adhesion molecule } 4 \text {, Landsteiner-Wiener } \\
\text { blood group }\end{array}$ & 1.8 & 2.3 & 2.0 \\
\hline NM_008048 & $\operatorname{lgfbp} 7$ & insulin-like growth factor binding protein 7 & 2.3 & 3.0 & 1.7 \\
\hline NM_008356 & Il13ra2 & interleukin 13 receptor, alpha 2 & 1.9 & 2.3 & 1.2 \\
\hline NM_008365 & $\| 18 \mathrm{r} 1$ & interleukin 18 receptor 1 & 3.1 & 3.2 & 2.2 \\
\hline NM_010582 & Itih2 & inter-alpha trypsin inhibitor, heavy chain 2 & 2.4 & 3.4 & 2.4 \\
\hline U69̄176 & Lama4 & laminin, alpha 4 & 2.1 & 2.6 & 1.8 \\
\hline M15525 & Lamb1-1 & laminin $B 1$ subunit 1 & 1.6 & 2.9 & 2.3 \\
\hline NM_008590 & Mest & mesoderm specific transcript & 2.9 & 3.8 & 1.9 \\
\hline NM_010794 & Mgat1 & mannoside acetylglucosaminyltransferase 1 & 2.6 & 2.9 & 1.6 \\
\hline NM_008597 & Mglap & matrix gamma-carboxyglutamate (gla) protein & 3.5 & 4.2 & 3.7 \\
\hline NM_011885 & Mrps12 & mitochondrial ribosomal protein $\mathrm{S} 12$ & 1.6 & 2.2 & 1.1 \\
\hline $\mathrm{BC} 013503$ & Ndufs 7 & NADH dehydrogenase (ubiquinone) Fe-S protein 7 & 2.7 & 2.0 & 1.4 \\
\hline NM_008721 & Npdc1 & neural proliferation, differentiation and control gene 1 & 2.0 & 2.6 & 2.0 \\
\hline AF273768 & Npy & neuropeptide $Y$ & 2.1 & 2.4 & 1.8 \\
\hline NM_011019 & Osmr & oncostatin $\mathrm{M}$ receptor & 2.8 & 3.8 & 2.5 \\
\hline Z25̄ 69 & Pros1 & protein S (alpha) & 2.7 & 3.8 & 1.9 \\
\hline NM_009049 & Resp18 & regulated endocrine-specific protein 18 & 1.9 & 2.3 & 1.6 \\
\hline NM_009136 & Scrg1 & scrapie responsive gene 1 & 2.0 & 2.0 & 2.1 \\
\hline NM_011892 & Sgcg & sarcoglycan, gamma (dystrophin-associated glycoprotein) & 1.9 & 2.2 & 1.4 \\
\hline NM_020561 & Smpdl3a & sphingomyelin phosphodiesterase, acid-like $3 \mathrm{~A}$ & 3.2 & 2.9 & 2.1 \\
\hline NM_011609 & Tnfrsf1a & tumor necrosis factor receptor superfamily, member $1 \mathrm{a}$ & 2.0 & 2.6 & 1.6 \\
\hline NM_016885 & Emcn & Endomucin & 2.4 & 2.9 & 2.6 \\
\hline
\end{tabular}

For experimental design, see Table 1. 
Table 4.

Genes that contribute to the enrichment of the Gene Ontology terms 'Mitochondrial processes', Carbohydrate metabolism', and 'Lipid metabolism' in gradually up-regulated genes (clusters F-G) by TBTO in mouse thymuses.

\begin{tabular}{|c|c|c|c|c|c|}
\hline \multirow[t]{2}{*}{ GenBank } & \multirow[t]{2}{*}{ Symbol } & \multirow[t]{2}{*}{ Gene name } & \multicolumn{3}{|c|}{ FR } \\
\hline & & & $3 d$ & $7 \mathrm{~d}$ & $14 \mathrm{~d}$ \\
\hline & & Mitochondrial processes & & & \\
\hline NM_011834 & Aadat & aminoadipate aminotransferase & 1.2 & 1.3 & 4.0 \\
\hline NM_009761 & Bnip3l & BCL2/adenovirus E1B 19kDa-interacting protein 3-like & -1.7 & -1.4 & 1.5 \\
\hline AJ278735 & Cabc1 & chaperone, $\mathrm{ABC} 1$ activity of bc1 complex like (S. pombe) & 1.8 & 2.4 & 4.2 \\
\hline NM_007702 & Cidea & $\begin{array}{l}\text { cell death-inducing DNA fragmentation factor, alpha subunit-like } \\
\text { effector A }\end{array}$ & 2.5 & 3.5 & 7.5 \\
\hline NM_007747 & Cox5a & cytochrome c oxidase, subunit Va & 2.5 & 1.9 & 3.5 \\
\hline NM_007748 & Cox6a1 & cytochrome c oxidase, subunit VI a, polypeptide 1 & 1.5 & 1.5 & 2.1 \\
\hline NM_009944 & Cox7a1 & cytochrome c oxidase, subunit VIla 1 & 1.2 & 1.6 & 4.4 \\
\hline NM_007749 & Cox7c & cytochrome c oxidase, subunit VIIc & -1.3 & -1.1 & 1.9 \\
\hline NM_007751 & Cox8b & cytochrome c oxidase, subunit VIIIb & 2.5 & 5.3 & 10.8 \\
\hline NM_007808 & Cycs & cytochrome c, somatic & -1.1 & 1.8 & 2.1 \\
\hline U72679 & Fh1 & fumarate hydratase 1 ** & -1.4 & -1.3 & 1.4 \\
\hline NM_008095 & Gbas & glioblastoma amplified sequence & 1.1 & 1.2 & 2.3 \\
\hline NM_010274 & Gpd2 & glycerol phosphate dehydrogenase 2 , mitochondrial ** & 1.0 & 1.3 & 2.6 \\
\hline NM_019946 & Mgst1 & microsomal glutathione S-transferase 1 & 1.5 & 1.6 & 3.9 \\
\hline NM_019443 & Ndufa1 & $\mathrm{NADH}$ dehydrogenase (ubiquinone) 1 alpha subcomplex, 1 & 1.6 & 1.2 & 2.5 \\
\hline U59509 & Ndufa4 & $\mathrm{NADH}$ dehydrogenase (ubiquinone) 1 alpha subcomplex, 4 & 1.2 & 1.0 & 2.6 \\
\hline U02971 & Ogdh & oxoglutarate dehydrogenase (lipoamide) ${ }^{* *}$ & -1.4 & -1.1 & 1.4 \\
\hline NM_008831 & $\mathrm{Phb}$ & Prohibitin & 1.3 & 1.8 & 2.2 \\
\hline AF095936 & Sdhb & succinate dehydrogenase complex, subunit B, iron sulfur (Ip) ** & -1.4 & 1.0 & 1.6 \\
\hline AF058955 & Sucla2 & succinate-Coenzyme A ligase, ADP-forming, beta subunit ** & 1.3 & 1.7 & 4.0 \\
\hline \multirow[t]{3}{*}{ AK005541 } & Trmt1 & tRNA (5-methylaminomethyl-2-thiouridylate)-methyltransferase 1 & 1.3 & 1.2 & 2.1 \\
\hline & & Carbohydrate metabolism & & & \\
\hline & & See 'Mitochondrion' $\left({ }^{\star \star}\right)$ & & & \\
\hline NM_013820 & Hk2 & hexokinase 2 & -1.3 & 1.2 & 2.0 \\
\hline NM_011044 & Pck1 & phosphoenolpyruvate carboxykinase 1 , cytosolic & 1.2 & 1.9 & 2.9 \\
\hline NM_018870 & Pgam2 & phosphoglycerate mutase 2 & 1.2 & 1.4 & 2.4 \\
\hline \multirow[t]{2}{*}{ U67611 } & Taldo1 & transaldolase 1 & 2.8 & 2.0 & 3.1 \\
\hline & & Lipid metabolism & & & \\
\hline NM_011921 & Aldh1a7 & aldehyde dehydrogenase family 1 , subfamily $A 7$ & 1.2 & 1.7 & 2.2 \\
\hline NM_007702 & Cidea & $\begin{array}{l}\text { cell death-inducing DNA fragmentation factor, alpha subunit-like } \\
\text { effector A }\end{array}$ & 2.5 & 3.5 & 7.5 \\
\hline NM_013493 & Cnbp1 & cellular nucleic acid binding protein 1 & -2.0 & -1.4 & 1.1 \\
\hline NM_010174 & Fabp3 & fatty acid binding protein 3 , muscle and heart & 1.3 & 1.6 & 2.8 \\
\hline NM_013839 & $\mathrm{Nr} 1 \mathrm{~h} 3$ & nuclear receptor subfamily 1 , group $\mathrm{H}$, member 3 & 1.9 & 1.7 & 2.7 \\
\hline NM_011044 & Pck1 & phosphoenolpyruvate carboxykinase 1 , cytosolic & 1.2 & 1.9 & 2.9 \\
\hline NM_008903 & Ppap2a & phosphatidic acid phosphatase $2 a$ & 1.8 & 2.6 & 2.8 \\
\hline AF410461 & Rpe65 & retinal pigment epithelium 65 & 1.6 & 1.5 & 2.8 \\
\hline NM_011674 & Ugt8 & UDP-glucuronosyltransferase 8 & 1.3 & 1.6 & 4.8 \\
\hline
\end{tabular}

** Involved in both mitochondrial processes and carbohydrate metabolism.

For experimental design, see Table 1. 


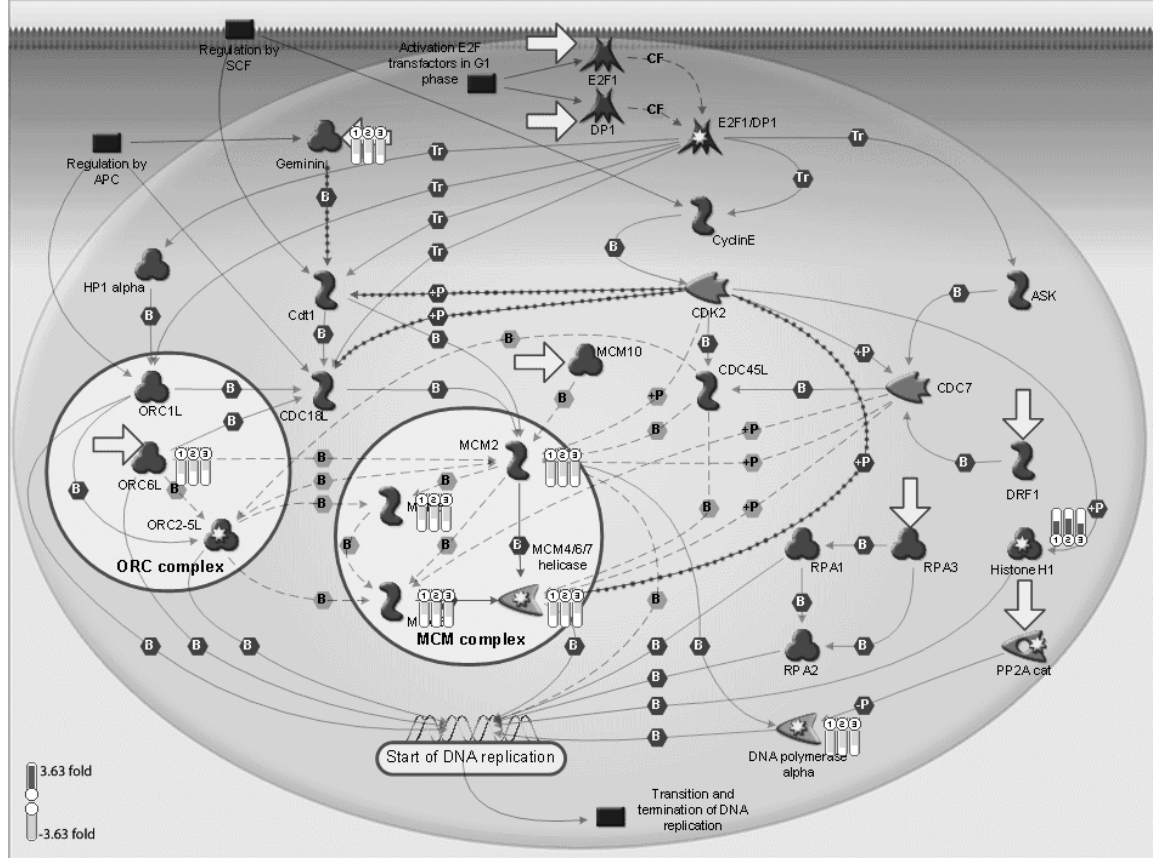

(a)

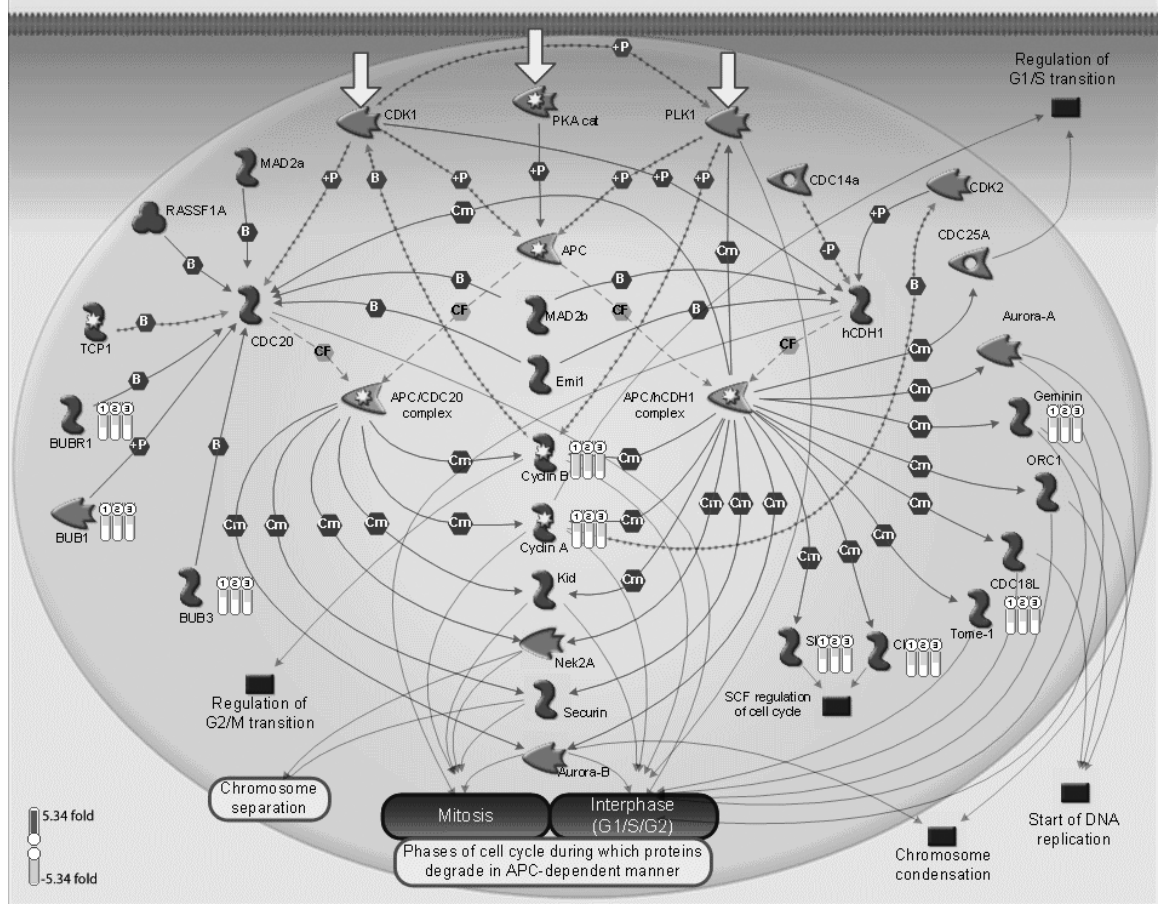

(b) 


\section{Figure 2.}

Regulation of cell cycle-related processes by TBTO in mouse thymuses visualized in MetaCore pathways. (a) Effect of TBTO on the start of DNA replication in the early S phase of the cell cycle. (b) Effect of TBTO on genes involved in cell cycle regulation by the anaphase-promoting complex (APC). C57BL/6 mice were exposed to $300 \mathrm{ppm}$ TBTO in the diet for 3, 7, or 14 days. Per exposure group or time-matched control group, 4 pools of 2 RNA samples of mouse thymuses were analyzed using microarrays comprising $11 \mathrm{~K}$ oligos with immunological or toxicological relevance spotted in duplicate. Involvement of differentially expressed (FDR $<0.05$ and FR $\leq-2$ or $\geq 2$ ) genes in specific cellular pathways and the extent of regulation of available pathways by TBTO were identified and visualized using MetaCore by GeneGo Inc. The depicted pathways involved a relatively high amount of differentially expressed genes. The extent of up- or down-regulation of hits compared to controls is indicated by the bars beside the genes; 1 . refers to the first time point of 3 days, 2 . to the second time point, and 3. to the third time point. In (a) arrows comprising a sign of the mechanism involved indicate a positive effect, dotted arrows a negative effect, in (b) it is the other way around. For legend, see http://portal.genego.com/legends/legend_6.png.

\section{Table 5.}

Mean weights of liver, thymus, and mesenteric lymph nodes (MLN) of TBTO-treated rats.

\begin{tabular}{|c|c|c|c|c|c|c|c|}
\hline \multirow[t]{2}{*}{ Organ } & \multirow{2}{*}{$\begin{array}{l}\text { Weight } \\
\left(g / 10^{-2} g\right)\end{array}$} & \multirow{2}{*}{$\begin{array}{l}\text { TBTO } \\
\text { (ppm) }\end{array}$} & \multicolumn{5}{|c|}{ Duration of exposure (days) } \\
\hline & & & 3 & & 7 & 14 & 28 \\
\hline \multirow[t]{8}{*}{ Thymus } & absolute & 0 & $0.51 \pm 0.06$ & & $0.61 \pm 0.03$ & $0.51 \pm 0.04$ & $0.45 \pm 0.03$ \\
\hline & & 5 & $0.58 \pm 0.04$ & & $0.56 \pm 0.02$ & $0.54 \pm 0.02$ & $0.48 \pm 0.04$ \\
\hline & & 20 & $0.55 \pm 0.04$ & & $0.51 \pm 0.03$ * & $0.56 \pm 0.5$ & $0.39 \pm 0.02$ \\
\hline & & 80 & $0.52 \pm 0.03$ & & $0.40 \pm 0.04$ * & $0.40 \pm 0.03$ * & $0.30 \pm 0.02$ * \\
\hline & relative & 0 & $0.15 \pm 0.02$ & & $0.16 \pm 0.01$ & $0.13 \pm 0.01$ & $0.11 \pm 0.01$ \\
\hline & & 5 & $0.17 \pm 0.01$ & & $0.15 \pm 0.01$ & $0.14 \pm 0.01$ & $0.12 \pm 0.01$ \\
\hline & & 20 & $0.16 \pm 0.01$ & & $0.14 \pm 0.01$ & $0.14 \pm 0.01$ & $0.10 \pm 0.01$ \\
\hline & & 80 & $0.16 \pm 0.01$ & & $0.11 \pm 0.01$ * & $0.10 \pm 0.01$ & $0.07 \pm 0.01$ * \\
\hline \multirow[t]{8}{*}{ MLN } & absolute & 0 & $0.25 \pm 0.02$ & & $0.35 \pm 0.02$ & $0.33 \pm 0.04$ & $0.30 \pm 0.02$ \\
\hline & & 5 & $0.22 \pm 0.01$ & & $0.28 \pm 0.01$ * & $0.35 \pm 0.02$ & $0.29 \pm 0.03$ \\
\hline & & 20 & $0.24 \pm 0.01$ & & $0.30 \pm 0.02$ & $0.36 \pm 0.04$ & $0.29 \pm 0.02$ \\
\hline & & 80 & $0.21 \pm 0.01$ & & $0.25 \pm 0.02$ * & $0.27 \pm 0.02$ * & $0.24 \pm 0.02$ * \\
\hline & relative & 0 & $0.08 \pm 0.01$ & & $0.09 \pm 0.01$ & $0.08 \pm 0.01$ & $0.07 \pm 0.01$ \\
\hline & & 5 & $0.06 \pm 0.01$ & & $0.08 \pm 0.01$ * & $0.09 \pm 0.01$ & $0.07 \pm 0.01$ \\
\hline & & 20 & $0.07 \pm 0.01$ & & $0.08 \pm 0.01$ & $0.09 \pm 0.01$ & $0.07 \pm 0.01$ \\
\hline & & 80 & $0.06 \pm 0.01$ & & $0.07 \pm 0.01$ * & $0.07 \pm 0.01$ & $0.06 \pm 0.01$ \\
\hline \multirow[t]{8}{*}{ Liver } & absolute & 0 & $12.65 \pm 1.69$ & & $15.61 \pm 0.30$ & $15.11 \pm .061$ & $15.04 \pm 0.23$ \\
\hline & & 5 & $14.80 \pm 0.53$ & * & $14.69 \pm 0.33$ & $13.87 \pm 0.36$ & $15.34 \pm 0.57$ \\
\hline & & 20 & $14.87 \pm 0.42$ & * & $15.50 \pm 0.36$ & $14.42 \pm 0.61$ & $14.84 \pm 0.40$ \\
\hline & & 80 & $13.95 \pm 0.32$ & & $14.89 \pm 0.46$ & $14.34 \pm 0.40$ & $14.85 \pm 0.49$ \\
\hline & relative & 0 & $3.72 \pm 0.42$ & & $4.07 \pm 0.10$ & $3.82 \pm 0.08$ & $3.70 \pm 0.04$ \\
\hline & & 5 & $4.28 \pm 0.12$ & * & $4.02 \pm 0.08$ & $3.63 \pm 0.06$ & $3.74 \pm 0.09$ \\
\hline & & 20 & $4.31 \pm 0.12$ & * & $4.12 \pm 0.06$ & $3.73 \pm 0.14$ & $3.63 \pm 0.07$ \\
\hline & & 80 & $4.19 \pm 0.09$ & * & $4.10 \pm 0.07$ & $3.74 \pm 0.07$ & $3.65 \pm 0.09$ \\
\hline
\end{tabular}

Wistar rats were exposed to $0,5,20$, or 80 ppm TBTO in the diet during $3,7,14$, or 28 days $(n=8)$. Average absolute and relative (i.e. corrected for body weight) organ weights are displayed in $\mathrm{g}$ and $10^{-2} \mathrm{~g}$, respectively, \pm SD. Significant $(p<0.05)$ changes in organ weights compared to the corresponding control group are indicated $\left({ }^{*}\right)$ per time point. 


\section{Analysis of TBTO-induced immunotoxicity in rats}

\section{ANIMAL AND ORGAN WEIGHTS}

The main effects of TBTO on animal growth were a 5 and $4 \%$ reduction in body weight gain compared to controls after 7 and 14 days of exposure to the highest dose of $80 \mathrm{ppm}$, respectively (data not shown). Thymus and mesenteric lymph node (MLN) weights were decreased at several TBTO doses and time points, whereas liver weights were generally increased after 3 days of exposure. Spleen weights were not affected by TBTO. Average absolute and relative thymus, MLN, and liver weights of the experimental groups and significant $(p<0.05)$ changes of those compared to the control group are summarized in Table 5. The reduction of thymus weight by TBTO was used to confirm the induction of a biological effect. Since only the highest dose of $80 \mathrm{ppm}$ TBTO caused a decrease in relative thymus weight, only this dose was included in microarray analysis.

\section{GENE EXPRESSION ANALYSIS}

The quality of all microarray hybridizations was sufficient to include them in the statistical analysis. Generally, PCA discriminated the three organs but could hardly distinguish the different exposure groups and time points (data not shown). As in the mouse experiment, all control samples could be pooled. No genes were found to be significantly differently expressed between the four groups exposed to $80 \mathrm{ppm}$ TBTO and the control pool with a FDR $<0.1$ in the thymus. The same was true for the spleen. In the liver, expression levels of 19 genes met this criterion. Nine of these oligos showed a maximal FR of $\leq-1.5$ or $\geq 1.5$ between any two groups and were considered differentially regulated by TBTO. When a FDR $<0.2$ was applied, significantly changed expression of 2 genes was found in thymus, and 1 gene was affected in the spleen. Now 49 oligos were regulated in the liver, 25 of which had a FR $\leq-1.5$ or $\geq 1.5$. Table 6 shows all regulated genes in liver, spleen and thymus of the rats exposed to 80 ppm TBTO for $3,7,14$, or 28 days.

The expression levels of Cdkn1a (strong time-dependent up-regulation), Cyp7a1 (constant down-regulation), and Nr1d1 (early up-regulation) were determined by real time RT-PCR. The latter gene was also measured in spleen RNA. All results corresponded to and thereby confirmed the microarray measurements (data not shown).

\section{PATHWAY ANALYSIS}

Application of less strict criteria for differential expression when studying regulation of cellular processes, prevents the omission of genes that do not reach significance when tested individually, but that provide useful information when analyzing them together with other, correlated oligos [55]. In the rat, significant GO term enrichment was found in the data set produced by application of the higher FDR only. Endoplasmatic reticulum and lipid metabolism were affected by TBTO in rat livers, and the involved genes were mainly downregulated (Table 6). Lipid metabolism was also the process to which the most pathways involving differentially expressed genes in our data set belonged according to MetaCore analysis. In particular, TBTO seems to interfere with lipid synthesis by down-regulation of Srebf1, also indicated as Srebp1. Srebp1 normally activates transcription of Fasn, Scd, and Acly, and expression of the genes encoding these proteins was also reduced. 
Table 6.

Differentially expressed genes in thymus, spleen, and liver of TBTO-treated rats.

\begin{tabular}{|c|c|c|c|c|c|c|c|c|}
\hline \multirow[t]{2}{*}{ GenBank } & \multirow[t]{2}{*}{ Symbol } & \multirow[t]{2}{*}{ Gene name } & \multirow[t]{2}{*}{ E.R. } & \multirow[t]{2}{*}{ Lipi } & \multicolumn{4}{|c|}{ FR } \\
\hline & & & & & $3 d$ & $7 \mathrm{~d}$ & $14 \mathrm{~d}$ & $28 \mathrm{~d}$ \\
\hline & & Thymus & & & & & & \\
\hline NM_031657 & Gprk6 & G protein-coupled receptor kinase 6 & & & -1.1 & 1.6 & 1.4 & 1.0 \\
\hline \multirow[t]{2}{*}{ NM_031325 } & Ugdh & UDP-glucose dehydrogeanse & & & -1.1 & 1.2 & 1.3 & -1.3 \\
\hline & & Spleen & & & & & & \\
\hline \multirow[t]{2}{*}{ M25804 } & Nr1d1 & $\begin{array}{l}\text { nuclear receptor subfamily } 1 \text {, group } \\
\text { D, member } 1\end{array}$ & & & 1.6 & 1.3 & 1.1 & 1.5 \\
\hline & & Liver & & & & & & \\
\hline NM_016987 & Acly & ATP citrate lyase & & * & -1.4 & -1.4 & -1.3 & -1.7 \\
\hline U24174 & Cdkn1a & cyclin-dependent kinase inhibitor $1 \mathrm{~A}$ & & & 1.1 & 1.3 & 1.6 & 1.6 \\
\hline NM_017158 & Cyp2c7 & $\begin{array}{l}\text { cytochrome P450, family } 2 \\
\text { subfamily c, polypeptide } 7\end{array}$ & * & & -1.3 & 1.0 & -1.7 & -1.7 \\
\hline X53477 & Cyp2c70 & $\begin{array}{l}\text { cytochrome P450, family } 2 \text {, } \\
\text { subfamily c, polypeptide } 70\end{array}$ & * & & -1.4 & -1.1 & 1.2 & -1.4 \\
\hline NM_012942 & Cyp7a1 & $\begin{array}{l}\text { cytochrome P450, family } 7 \text {, } \\
\text { subfamily a, polypeptide } 1\end{array}$ & * & * & -2.0 & -3.3 & -1.3 & -1.7 \\
\hline NM_031241 & Cyp8b1 & $\begin{array}{l}\text { cytochrome P450, family } 8 \\
\text { subfamily b, polypeptide } 1\end{array}$ & * & * & 1.2 & -1.4 & -1.7 & 1.7 \\
\hline BG668317 & & ESTs, moderately similar to Heat & & & -1.4 & -1.3 & 1.0 & -1.7 \\
\hline NM_017332 & Fasn & $\begin{array}{l}\text { shock protein HSP 90-beta (HSP 84) } \\
\text { fatty acid synthase }\end{array}$ & & * & -2.0 & -2.5 & -1.4 & -2.5 \\
\hline AJ245707 & $\mathrm{Hpcl} 2$ & $\begin{array}{l}\text { 2-hydroxyphytanoyl-Coenzyme A } \\
\text { lyase }\end{array}$ & & & 1.2 & 1.5 & 1.7 & 1.8 \\
\hline NM_017020 & $116 r$ & interleukin 6 receptor & & & 1.3 & 1.2 & 1.5 & 1.5 \\
\hline NM_012771 & Lyz & lysozyme & & & -2.0 & -2.0 & -1.7 & -1.7 \\
\hline NM_022635 & Nat8 & $\mathrm{N}$-acetyltransferase 8 (camello like) & * & & -1.7 & -1.7 & 1.4 & -1.4 \\
\hline M25804 & Nr1d1 & $\begin{array}{l}\text { nuclear receptor subfamily } 1 \text {, group } \\
\text { D, member } 1\end{array}$ & & & 1.7 & 1.1 & 1 & 1.1 \\
\hline NM_022941 & $\mathrm{Nr1i3}$ & $\begin{array}{l}\text { nuclear receptor subfamily } 1 \text {, group } \\
\text { I, member } 3\end{array}$ & & & 1.4 & 1.4 & 1.7 & 1.9 \\
\hline NM_138504 & Okl38 & pregnancy-induced growth inhibitor & & & 1.7 & 1.2 & -1.1 & -1.4 \\
\hline NM_031678 & Per2 & period homolog 2 (Drosophila) & & & -2.0 & -1.7 & 1.0 & -1.7 \\
\hline NM_031579 & Ptp4a1 & protein tyrosine phosphatase $4 \mathrm{a} 1$ & & & 1.1 & 1.4 & 1.4 & 1.5 \\
\hline J02585 & Scd1 & stearoyl-Coenzyme A desaturase 1 & * & * & -1.1 & 1.1 & -1.4 & -5.0 \\
\hline NM_019232 & Sgk & $\begin{array}{l}\text { serum/glucocorticoid regulated } \\
\text { kinase }\end{array}$ & & & -1.4 & -1.7 & -1.7 & -2.0 \\
\hline AB027562 & Sh3bp5 & $\begin{array}{l}\text { SH3-domain binding protein } 5 \text { (BTK- } \\
\text { associated) }\end{array}$ & & & 1.1 & 1.6 & 1.0 & 1.4 \\
\hline AJ223355 & $\begin{array}{l}\text { Slc25a1 } \\
0\end{array}$ & $\begin{array}{l}\text { solute carrier family } 25 \\
\text { (mitochondrial carrier; dicarboxylate } \\
\text { transporter), member } 10\end{array}$ & & & -1.3 & -1.7 & -1.3 & -1.1 \\
\hline NM_012674 & Spink1 & serine protease inhibitor, Kazal type & & & 1.1 & 1.1 & 1.2 & 1.5 \\
\hline AF286470 & Srebf1 & $\begin{array}{l}\text { sterol regulatory element binding } \\
\text { factor } 1\end{array}$ & * & * & -1.3 & -2.0 & -1.1 & -2.0 \\
\hline M58040 & Tfrc & transferrin receptor & & & -1.3 & -1.3 & 1.4 & -0.8 \\
\hline M96548 & Znf354a & zinc finger protein $354 \mathrm{~A}$ & & & -1.3 & 1.1 & 2.3 & 1.4 \\
\hline
\end{tabular}

Wistar rats were exposed to 0 or $80 \mathrm{ppm}$ TBTO in the diet during $3,7,14$, or 28 days $(n=5)$, where after microarray analysis was performed in the livers, spleens and thymuses. Criteria for differential gene expression were FDR $<0.2$ and maximal FR between any two groups $\leq-1.5$ or $\geq 1.5$. Significantly enriched (FDR <0.1) Gene Ontology terms were endoplasmatic reticulum ('E.R.') and lipid metabolism ('lipid'). The corresponding genes are indicated in the respective columns by '*'. The FRs for each gene are displayed as compared to the control group. 


\section{Discussion}

Oral TBTO administration resulted in a macroscopically observed thymus involution in the mice and rats included in both experiments described here, which corresponds to the immunotoxic effect of TBTO that has been observed in the past $[19,27]$. The microarray analyses that were performed in these animals provide insight into gene expression changes that are associated with the toxicity of TBTO.

In the mouse, the most prominent effect of TBTO in the thymus was regulation of immune-related genes. This was mainly caused by reduced expression of several cell surface determinants and receptors. Not only was GO term enrichment for such proteins found in the subset of down-regulated genes, but all the regulated un-annotated $T$ cell receptor chains were down-regulated as well. Such effects result in repressed $T$ cell activation, which will also be the effect of the down-regulation of the CD28 signaling pathway. In contrast, most un-annotated immunoglobulin chains were up-regulated. Although this could indicate that TBTO, through its effects on T lymphocytes, changes the production of immunoglobulins by $B$ cells, this interaction between the two cell types usually takes place outside of the thymus. Moreover, B cell influx in the thymus, which could explain the presence of an increased amount of immunoglobulin transcripts, is not a known consequence of TBTO exposure.

Another clear TBTO-induced effect, that was detected by the GO term enrichment as well as the MetaCore analysis, was the clear down-regulation of cell cyclerelated processes. Reduced expression of cyclins operating in all phases of the cell cycle, repressed synthesis of nucleotides necessary for DNA synthesis, and inhibition of DNA replication are some of the involved mechanisms. This suggests that in this study inhibition of cell proliferation was the primary mechanism responsible for TBTO-induced thymus atrophy, instead of induction of apoptosis, as had been suggested by others $[40,42,43]$. The same was concluded from results of previous experiments $[19,21,38,39]$.

It should, however, be noted that a selective cytotoxic effect of TBTO on a subpopulation of rapidly dividing lymphocytes, as reported by Snoeij et al. [21], can cause detection of transcripts of slowly proliferating cells remaining in the thymus only, resulting in a gene expression profile that resembles down-regulation of proliferation when compared to the controls [56]. This could in part explain our findings. Moreover, lymphocyte depletion by butyltin compounds can change the proportions of the diverse cell populations in the thymus [57]. The reduction of cell surface determinant and $\mathrm{T}$ cell receptor expression in the thymus after TBTO administration may therefore also be the consequence of reduction of certain cell types, which will cause less of their cell surface markers to be present. Taken together, the results suggest that the suppressed immune response that has been noted after TBTO exposure may not only be caused indirectly by thymus atrophy and thereby depletion of $\mathrm{T}$ cells, but possibly also directly by interference with $\mathrm{T}$ cell activation.

Another effect observed in mouse thymuses after TBTO exposure was a reduced expression of ribosomal proteins. This observation may explain the reduction of protein biosynthesis that has sometimes been noticed after TBT exposure, and suggests that this is not caused by a depletion of energy alone [58,59]. Furthermore, an up-regulated expression of genes representing extracellular proteins was detected after 3 and 7 days of TBTO administration. Although no clear processes can be distinguished in this group of 
genes, some genes code for collagen or are involved in cell adhesion or blood coagulation.

Mitochondrial processes, in particular cytochrome c oxidases and oxidative phosphorylation, were found to be up-regulated time-dependently. This indicates a stimulation of the electron transport chain and therefore increased ATP synthesis would be expected eventually. Moreover, a stimulation of the citric acid cycle was observed. However, TBT was previously reported to disturb energy metabolism as a result of uncoupling of oxidative phosphorylation in mitochondria. A direct interaction of TBT with mitochondrial components, structural damage to and swelling of mitochondria, a loss of ATPase or ATP synthase activities, and induction of ion exchange across the inner mitochondrial membrane have been detected in the past [1,24,60-62]. These processes may explain the increased lactate production and decreased cellular ATP levels that were observed after TBT exposure [24,58,59,63-65]. Possibly, TBTO interfered with the functioning of cytochrome $c$ oxidases, as was found for triphenyltin chloride [66], resulting in a compensatory up-regulation of these enzymes. Alternatively, the induced cytochrome c expression may be indicative for induction of apoptosis by TBTO at a later time point, since mitochondrial activation has been found to precede apoptosis induced by several stimuli [67].

Finally, gradual up-regulation of carbohydrate and of lipid metabolism were detected in mouse thymuses at the gene expression level. Some of the genes involved in carbohydrate metabolism were also involved in mitochondrial functioning and may thus be regulated as a consequence of the mitochondrial effects. Another explanation for the increased substrate metabolism may be the occurrence of a general stress response because of the high dose of TBTO that was administered. This requires energy, which may be produced by increased metabolism of these substrates. Interference of TBT with lipid metabolism, as well as adipogenesis, was found in other studies as well [13]. It is well imaginable that the nuclear receptor RXR was involved in the effect of TBTO on lipid metabolism. We did not detect up-regulation of this receptor, but three genes of which the transcription is induced after dimerization of RXR with PPARY and that regulate $\beta$ oxidation of fatty acids, were up-regulated. Activation of this receptor by organotin compounds has been reported several times [68-71]. Two other nuclear receptors that were up-regulated in mouse thymuses and were previously reported to be activated by TBT [72] may have mediated the regulation of lipid metabolism as well. Nr1h3, or LXR, regulates lipogenesis and is involved in lipid homeostasis. It is known to promote transport of cholesterol to the liver for degradation to bile acids [73], but has recently been found to operate in immune cells as well [74]. PPARy is involved in adipocyte differentiation [75]. Moreover, activation of this receptor was observed to alter immune responses, for instance by induction of interleukin (IL)-12 and inhibition of IL-4 production and by reducing proliferation of activated T cells [76-80].

In contrast to the experiments in mice, a lower dose of TBTO that still caused significant thymus involution in rats and immunotoxicity in previous experiments, had hardly any effect on the gene expression in this organ. No effects on spleen weight were detected, and as in the thymus, hardly any regulation of gene expression was found. A significant increase of liver weight (which was later on reversed) was observed shortly after the start of TBTO administration, which may be a result of TBTO-induced liver damage. The only pathway enrichment that was detected in the rat experiment was observed in the 
liver. The endoplasmatic reticulum and lipid metabolism were both significantly affected by TBTO, and there was a partial overlap of genes belonging to these categories.

The genes involved in lipid metabolism that were affected in the rat liver were different from those detected in the mouse thymus and were mostly down-regulated. Different processes are therefore likely to have occurred. For example, whereas in the mouse thymus oxidation of fatty acids was increased, in the rat liver lipid synthesis was inhibited by down-regulation of Srebp1. Activation of the LXR/RXR complex would have stimulated the transcription of this gene and is thus not likely to have occurred here. Srebp1 can activate transcription of Cyp8b1 [81], and both genes were down-regulated in rat livers. Cyp7a1 is, just like Cyp8b1, involved in cholesterol metabolism and was also down-regulated. Its expression can be controlled by LXR [82]. Cyp2c7 and Cyp2c70 are two other cytochrome P450 enzymes of which the transcription was repressed by TBTO. Inhibition of P450 enzymes by xenobiotics and bile acids is a phenomenon that is known to occur and has been explained by involvement of nuclear receptors [82-84]. The nuclear receptors $\mathrm{Nr} 1 \mathrm{i} 3$, or $\mathrm{CAR}$, and $\mathrm{Nr} 1 \mathrm{~d} 1$ were found to be up-regulated in rat livers. CAR has a role in regulating liver homeostasis in response to xenobiotic stress, but was also found to interact with other nuclear receptors, such as LXR [85].

The relative absence of gene expression changes in the rat thymus may be explained by effects of TBTO that contribute to thymus involution but do not involve transcriptional regulation. It is known that many toxicants affect enzyme activity, DNA integrity, redox status, or membrane integrity or bind to cellular macromolecules [86]. TBTO has for instance been reported to interact with thiol groups, the cell membrane, and the cytoskeleton [1,9]. In addition, regulatory signals can affect proteins posttranslationally [87]. The gene expression profile does therefore not necessarily reveal the changes in functional state of the cell [88]. On the other hand, microarray analysis did reveal the toxic effects of TBTO in the mouse experiment. The reason for this difference may be the higher dose of TBTO that was administered to the mice compared to the rats and the more severe thymus atrophy, as observed macroscopically, that was induced in the mice. It has been argued before that relatively toxic doses of chemicals must be administered to obtain significant changes in gene expression [89], and that compounds affect different genes and pathways depending on the dose administered [55]. If this is true, gene expression analysis was not more sensitive in detection of the primary effect of TBTO in rats than the traditional toxicological endpoints, even though that has often been suggested to be an advantage of toxicogenomics [45,90,91]. Alternatively, although organotin compounds have immunosuppressive effects in both mouse and rat lymphocytes, the molecular mechanisms of action may differ between these species, which may cause differences in gene expression profiles.

It must be noted that the use of a high dose in mice may have caused induction of general toxic or stress responses in the thymuses besides the specific immunosuppressive effects of TBTO. Since little experimental data on transcriptome alterations associated with immunotoxicity caused by xenobiotics are available at this moment, the high dose was used in order to ensure induction of gene expression changes. Until effects of other doses have been assessed in additional organs in mice as well as in rats, the presented data should be considered as preliminary and merely indicative of the potential of microarray studies to detect mechanisms of action of TBTO. 
The detection of effects that have previously been described in the literature suggests, however, that specific gene expression regulation by TBTO was identified as well.

In conclusion, we were able to detect the primary effect of TBTO in mouse thymuses using microarray analysis. Several cellular processes that may contribute to the toxic mechanisms of action, most notably reduction of expression of cell surface determinants and $\mathrm{T}$ cell receptor chains, suppression of cell proliferation, and a possible involvement of nuclear receptors in interference with lipid metabolism by TBTO, were also revealed. In a comparable experiment in rats receiving a lower dose of TBTO, we only detected regulation of gene expression in the liver. Hence, immunotoxic effects can be demonstrated by microarray analysis, but apparently, dose and inter-species differences are clearly reflected in gene expression profiles.

\section{Acknowledgements}

We thank Femke van den Berg and Mirjam Schaap for their efforts in the mouse experiment; Tessa van der Hoeven for performing the murine microarrays; Cor Schot and co-workers for the housing of the mice; Hans Strootman, Diane Kegler and Piet van Schaijk for the coordination of the rat experiment; Eric Gremmer for his assistence in the rat microarrays; and Coen Moolenbeek for all the biotechnical support. 


\section{References}

1. Fent, K. (1996) Ecotoxicology of organotin compounds. Crit Rev Toxicol 26, 1-117.

2. Hoch, M. (2001) Organotin compounds in the environment - an overview. Appl Geochem 16, 719-743.

3. Kannan, K., Tanabe, S., Tatsukawa, R. (1995) Occurrence of butyltin residues in certain foodstuffs. Bull Environ Contam Toxicol 55, 510-516.

4. Iwata, H., Tanabe, S., Mizuno, T., Tatsukawa, R. (1997) Bioaccumulation of butyltin compounds in marine mammals: the specific tissue distribution and composition. Appl Organomet Chem 11, 257-264.

5. Kannan, K., Corsolini, S., Focardi, S., Tanabe, S., Tatsukawa, R. (1996) Accumulation pattern of butyltin compounds in dolphin, tuna, and shark collected from Italian coastal waters. Arch Environ Contam Toxicol 31, 19-23.

6. Kannan, K., Senthilkumar, K., Elliott, J.E., Feyk, L.A., Giesy, J.P. (1998) Occurrence of butyltin compounds in tissues of water birds and seaducks from the united states and canada. Arch Environ Contam Toxicol 35, 6469.

7. Kannan, K., Senthilkumar, K., Giesy, J.P. (1999) Occurrence of butyltin compounds in human blood. Environ Sci Technol 33, 1776-1779.

8. Appel, K.E. (2004) Organotin compounds: toxicokinetic aspects. Drug Metab Rev 36, 763-786.

9. EFSA (2004) Opinion of the Scientific Panel on Contaminants in the Food Chain on a request from the Commission to assess the health risks to consumers associated with exposure to organotins in foodstuffs. The EFSA Journal 102, 1-119.

10. Doering, D.D., Steckelbroeck, S., Doering, T., Klingmuller, D. (2002) Effects of butyltins on human 5alphareductase type 1 and type 2 activity. Steroids $67,859-867$.

11. Funahashi, N., Iwasaki, I., Ide, G. (1980) Effects of bis (tri-n-butyltin) oxide on endocrine and lymphoid organs of male rats. Acta Pathol Jpn 30, 955-966.

12. Grote, K., Stahlschmidt, B., Talsness, C.E., Gericke, C., Appel, K.E., Chahoud, I. (2004) Effects of organotin compounds on pubertal male rats. Toxicology 202, 145-158.

13. Inadera, H. (2006) The immune system as a target for environmental chemicals: Xenoestrogens and other compounds. Toxicol Lett 164, 191-206.

14. Krajnc, E.I., Wester, P.W., Loeber, J.G., Van Leeuwen, F.X., Vos, J.G., Vaessen, H.A., Van der Heijden, C.A. (1984) Toxicity of bis(tri-n-butyltin)oxide in the rat. I. Short-term effects on general parameters and on the endocrine and lymphoid systems. Toxicol Appl Pharmacol 75, 363-386.

15. Shimasaki, Y., Kitano, T., Oshima, Y., Inoue, S., Imada, N., Honjo, T. (2003) Tributyltin causes masculinization in fish. Environ Toxicol Chem 22, 141-144.

16. Yu, W.J., Nam, S.Y., Kim, Y.C., Lee, B.J., Yun, Y.W. (2003) Effects of tributyltin chloride on the reproductive system in pubertal male rats. $\mathrm{J}$ Vet Sci 4, 29-34.

17. Wester, P.W., Krajnc, E.I., Van Leeuwen, F.X., Loeber, J.G., Van der Heijden, C.A., Vaessen, H.A., Helleman, P.W. (1990) Chronic toxicity and carcinogenicity of bis(tri- $n$-butyltin)oxide (TBTO) in the rat. Food Chem Toxicol 28, 179-196.

18. Snoeij, N.J., Penninks, A.H., Seinen, W. (1987) Biological activity of organotin compounds--an overview. Environ Res 44, 335-353.

19. Vos, J.G., De Klerk, A., Krajnc, E.I., Kruizinga, W., Van Ommen, B., Rozing, J. (1984) Toxicity of bis(tri-nbutyltin)oxide in the rat. II. Suppression of thymus-dependent immune responses and of parameters of nonspecific resistance after short-term exposure. Toxicol Appl Pharmacol 75, 387-408.

20. Bressa, G., Hinton, R.H., Price, S.C., Isbir, M., Ahmed, R.S., Grasso, P. (1991) Immunotoxicity of tri- $n$ butyltin oxide (TBTO) and tri- $n$-butyltin chloride (TBTC) in the rat. J Appl Toxicol 11, 397-402.

21. Snoeij, N.J., Penninks, A.H., Seinen, W. (1988) Dibutyltin and tributyltin compounds induce thymus atrophy in rats due to a selective action on thymic lymphoblasts. Int J Immunopharmacol 10, 891-899.

22. De Waal, E.J., Schuurman, H.J., Van Loveren, H., Vos, J.G. (1997) Differential effects of 2,3,7,8tetrachlorodibenzo-p-dioxin, bis(tri- $n$ - butyltin) oxide and cyclosporine on thymus histophysiology. Crit Rev Toxicol 27, 381-430.

23. De Waal, E.J., Schuurman, H.J., Rademakers, L.H., Van Loveren, H., Vos, J.G. (1993) The cortical epithelium of the rat thymus after in vivo exposure to bis(tri- $n$-butyltin)oxide (TBTO). An (immuno)histological and ultrastructural study. Arch Toxicol 67, 186-192.

24. Boyer, I.J. (1989) Toxicity of dibutyltin, tributyltin and other organotin compounds to humans and to experimental animals. Toxicology 55, 253-298.

25. Schuurman, H.J., Van Loveren, H., Rozing, J., Vos, J.G. (1992) Chemicals trophic for the thymus: risk for immunodeficiency and autoimmunity. Int J Immunopharmacol 14, 369-375. 
26. Smialowicz, R.J., Riddle, M.M., Rogers, R.R., Leubke, R.W., Copeland, C.B., Ernst, G.G. (1990) Immune alterations in rats following subacute exposure to tributyltin oxide. Toxicology 64, 169-178.

27. Verdier, F., Virat, M., Schweinfurth, H., Descotes, J. (1991) Immunotoxicity of bis(tri- $n$-butyltin) oxide in the rat. J Toxicol Environ Health 32, 307-317.

28. Vos, J.G., De Klerk, A., Krajnc, E.I., Van Loveren, H., Rozing, J. (1990) Immunotoxicity of bis(tri- $n$ butyltin)oxide in the rat: effects on thymus-dependent immunity and on nonspecific resistance following longterm exposure in young versus aged rats. Toxicol Appl Pharmacol 105, 144-155.

29. Aluoch, A.O., Odman-Ghazi, S.O., Whalen, M.M. (2006) Alteration of an essential NK cell signaling pathway by low doses of tributyltin in human natural killer cells. Toxicology 224, 229-237.

30. Smialowicz, R.J., Riddle, M.M., Rogers, R.R., Luebke, R.W., Copeland, C.B. (1989) Immunotoxicity of tributyltin oxide in rats exposed as adults or pre- weanlings. Toxicology 57, 97-111.

31. Van Loveren, H., Krajnc, E.I., Rombout, P.J., Blommaert, F.A., Vos, J.G. (1990) Effects of ozone, hexachlorobenzene, and bis(tri- $n$-butyltin)oxide on natural killer activity in the rat lung. Toxicol Appl Pharmacol 102, 21-33.

32. Whalen, M.M., Green, S.A., Loganathan, B.G. (2002) Brief butyltin exposure induces irreversible inhibition of the cytotoxic function on human natural killer cells, in vitro. Environ Res 88, $19-29$.

33. Wilson, S., Dzon, L., Reed, A., Pruitt, M., Whalen, M.M. (2004) Effects of in vitro exposure to low levels of organotin and carbamate pesticides on human natural killer cell cytotoxic function. Environ Toxicol 19, 554563.

34. Kergosien, D.H., Rice, C.D. (1998) Macrophage secretory function is enhanced by low doses of tributyltinoxide (TBTO), but not tributyltin-chloride (TBTCI). Arch Environ Contam Toxicol 34, 223-228.

35. Kato, T., Uchikawa, R., Yamada, M., Arizono, N., Oikawa, S., Kawanishi, S., Nishio, A., Nakase, H., Kuribayashi, K. (2004) Environmental pollutant tributyltin promotes Th2 polarization and exacerbates airway inflammation. Eur J Immunol 34, 1312-1321.

36. Kato, T., Tada-Oikawa, S., Takahashi, K., Saito, K., Wang, L., Nishio, A., Hakamada-Taguchi, R., Kawanishi, S., Kuribayashi, K. (2006) Endocrine disruptors that deplete glutathione levels in APC promote Th2 polarization in mice leading to the exacerbation of airway inflammation. Eur J Immunol 36, 1199-1209.

37. Van den Berg, F.A., Baken, K.A., Vermeulen, J.P., Gremmer, E.R., Van Steeg, H., Van Loveren, H. (2005) Use of the local lymph node assay in assessment of immune function. Toxicology 211, 107-114.

38. Nakata, H., Sakakibara, A., Kanoh, M., Kudo, S., Watanabe, H., Nagai, N., Miyazaki, N., Asano, Y., Tanabe, S. (2002) Evaluation of mitogen-induced responses in marine mammal and human lymphocytes by in-vitro exposure of butyltins and non-ortho coplanar PCBs. Environ Pollut 120, 245-253.

39. Vandebriel, R.J., Spiekstra, S.W., Hudspith, B.N., Meredith, C., Van Loveren, H. (1999) In vitro exposure effects of cyclosporin A and bis(tri- $n$-butyltin)oxide on lymphocyte proliferation, cytokine (receptor) mRNA expression, and cell surface marker expression in rat thymocytes and splenocytes. Toxicology 135, 49-66.

40. Aw, T.Y., Nicotera, P., Manzo, L., Orrenius, S. (1990) Tributyltin stimulates apoptosis in rat thymocytes. Arch Biochem Biophys 283, 46-50.

41. Gennari, A., Potters, M., Seinen, W., Pieters, R. (1997) Organotin-induced apoptosis as observed in vitro is not relevant for induction of thymus atrophy at antiproliferative doses. Toxicol Appl Pharmacol 147, 259-266.

42. Raffray, M., Cohen, G.M. (1991) Bis(tri-n-butyltin)oxide induces programmed cell death (apoptosis) in immature rat thymocytes. Arch Toxicol 65, 135-139.

43. Raffray, M., Cohen, G.M. (1993) Thymocyte apoptosis as a mechanism for tributyltin-induced thymic atrophy in vivo. Arch Toxicol 67, 231-236.

44. Zucker, R.M., Elstein, K.H., Thomas, D.J., Rogers, J.M. (1994) Tributyltin and dexamethasone induce apoptosis in rat thymocytes by mutually antagonistic mechanisms. Toxicol Appl Pharmacol 127, 163-170.

45. de Longueville, F., Bertholet, V., Remacle, J. (2004) DNA microarrays as a tool in toxicogenomics. Comb Chem High Throughput Screen 7, 207-211.

46. Lettieri, T. (2006) Recent applications of DNA microarray technology to toxicology and ecotoxicology. Environ Health Perspect 114, 4-9.

47. Waters, M.D., Fostel, J.M. (2004) Toxicogenomics and systems toxicology: aims and prospects. Nat Rev Genet 5, 936-948.

48. Azumi, K., Fujie, M., Usami, T., Miki, Y., Satoh, N. (2004) A cDNA microarray technique applied for analysis of global gene expression profiles in tributyltin-exposed ascidians. Mar Environ Res 58, 543-546.

49. Dubey, S.K., Tokashiki, T., Suzuki, S. (2006) Microarray-mediated transcriptome analysis of the tributyltin (TBT)-resistant bacterium Pseudomonas aeruginosa 25W in the presence of TBT. J Microbiol 44, 200-205.

50. Kishi, H., Nemoto, M., Enomoto, M., Shinoda, M., Kawanobe, T., Matsui, H. (2006) Acute toxic effects of dioctyltin on immune system of rats. Environ Toxicol Pharmacol 22, 240-247.

51. Yoshizuka, M., Hara, K., Haramaki, N., Yokoyama, M., Mori, N., Doi, Y., Kawahara, A., Fujimoto, S. (1992) Studies on the hepatotoxicity induced by bis (tributyltin) oxide. Arch Toxicol 66, 182-187. 
52. Van de Peppel, J., Kemmeren, P., Van Bakel, H., Radonjic, M., Van Leenen, D., Holstege, F.C. (2003) Monitoring global messenger RNA changes in externally controlled microarray experiments. EMBO Rep 4, 387-393.

53. Pennings, J.L.A., Heisterkamp, S.H. (2004) Normal Probability Plots for Quality Assessment of Microarray Experiments. Abstract. Proceedings of the 12th International Conference on Intelligent Systems for Molecular Biology and the 3rd European Conference on Computational Biology 143-

54. Benjamini, Y., Hochberg, Y. (1995) Controlling the false discovery rate: a practical and powerful approach to multiple testing. J Roy Stat Soc B 57, 289-300.

55. Steiner, G., Suter, L., Boess, F., Gasser, R., De Vera, M.C., Albertini, S., Ruepp, S. (2004) Discriminating different classes of toxicants by transcript profiling. Environ Health Perspect 112, 1236-1248.

56. Irwin, R.D., Boorman, G.A., Cunningham, M.L., Heinloth, A.N., Malarkey, D.E., Paules, R.S. (2004) Application of Toxicogenomics to Toxicology: Basic Concepts in the Analysis of Microarray Data. Toxicol Pathol 32, 72-83.

57. Pieters, R.H., Bol, M., Ariens, T., Punt, P., Seinen, W., Bloksma, N., Penninks, A.H. (1994) Selective inhibition of immature CD4-CD8+ thymocyte proliferation, but not differentiation, by the thymus atrophyinducing compound di-n-butyltin dichloride. Immunology 81, 261-267.

58. Marinovich, M., Viviani, B., Galli, C.L. (1990) Reversibility of tributyltin-chloride-induced protein synthesis inhibition after ATP recovery in HEL-30 cells. Toxicol Lett 52, 311-317.

59. Snoeij, N.J., Punt, P.M., Penninks, A.H., Seinen, W. (1986) Effects of tri- $n$-butyltin chloride on energy metabolism, macromolecular synthesis, precursor uptake and cyclic AMP production in isolated rat thymocytes. Biochim Biophys Acta 852, 234-243.

60. von Ballmoos, C., Brunner, J., Dimroth, P. (2004) The ion channel of F-ATP synthase is the target of toxic organotin compounds. Proc Natl Acad Sci U S A 101, 11239-11244.

61. Stridh, H., Orrenius, S., Hampton, M.B. (1999) Caspase involvement in the induction of apoptosis by the environmental toxicants tributyltin and triphenyltin. Toxicol Appl Pharmacol 156, 141-146.

62. Gogvadze, V., Stridh, H., Orrenius, S., Cotgreave, I. (2002) Tributyltin causes cytochrome C release from isolated mitochondria by two discrete mechanisms. Biochem Biophys Res Commun 292, 904-908.

63. Snoeij, N.J., Van Rooijen, H.J., Penninks, A.H., Seinen, W. (1986) Effects of various inhibitors of oxidative phosphorylation on energy metabolism, macromolecular synthesis and cyclic AMP production in isolated rat thymocytes. A regulating role for the cellular energy state in macromolecular synthesis and cyclic AMP production. Biochem Biophys Acta 852, 244-253.

64. Raffray, M., McCarthy, D., Snowden, R.T., Cohen, G.M. (1993) Apoptosis as a mechanism of tributyltin cytotoxicity to thymocytes: relationship of apoptotic markers to biochemical and cellular effects. Toxicol Appl Pharmacol 119, 122-130.

65. Chow, S.C., Kass, G.E., McCabe, M.J., Jr., Orrenius, S. (1992) Tributyltin increases cytosolic free Ca2+ concentration in thymocytes by mobilizing intracellular $\mathrm{Ca} 2+$, activating a $\mathrm{Ca} 2+$ entry pathway, and inhibiting Ca2+ efflux. Arch Biochem Biophys 298, 143-149.

66. Barranco, J., Darszon, A., Gomez-Puyou, A. (1981) Extraction of mitochondrial protein-lipid complexes into organic solvents: inhibition of cytochrome oxidase electron transport by dicyclohexylcarbodiimide and triphenyltin chloride. Biochem Biophys Res Commun 100, 1402-1408.

67. Chandra, D., Liu, J.W., Tang, D.G. (2002) Early mitochondrial activation and cytochrome c up-regulation during apoptosis. J Biol Chem 277, 50842-50854.

68. Grun, F., Blumberg, B. (2006) Environmental obesogens: organotins and endocrine disruption via nuclear receptor signaling. Endocrinology 147, S50-S55.

69. Kanayama, T., Kobayashi, N., Mamiya, S., Nakanishi, T., Nishikawa, J. (2005) Organotin compounds promote adipocyte differentiation as agonists of the peroxisome proliferator-activated receptor gamma/retinoid X receptor pathway. Mol Pharmacol 67, 766-774.

70. Nakanishi, T., Nishikawa, J., Hiromori, Y., Yokoyama, H., Koyanagi, M., Takasuga, S., Ishizaki, J., Watanabe, M., Isa, S., Utoguchi, N., Itoh, N., Kohno, Y., Nishihara, T., Tanaka, K. (2005) Trialkyltin compounds bind retinoid $X$ receptor to alter human placental endocrine functions. Mol Endocrinol 19, 25022516.

71. Nishikawa, J., Mamiya, S., Kanayama, T., Nishikawa, T., Shiraishi, F., Horiguchi, T. (2004) Involvement of the retinoid $X$ receptor in the development of imposex caused by organotins in gastropods. Environ Sci Technol 38, 6271-6276.

72. Grun, F., Watanabe, H., Zamanian, Z., Maeda, L., Arima, K., Chubacha, R., Gardiner, D.M., Kanno, J., Iguchi, T., Blumberg, B. (2006) Endocrine disrupting organotin compounds are potent inducers of adipogenesis in vertebrates. Mol Endocrinol

73. Chiang, J.Y. (2002) Bile acid regulation of gene expression: roles of nuclear hormone receptors. Endocr Rev 23, 443-463. 
74. Schote, A.B., Turner, J.D., Schiltz, J., Muller, C.P. (2006) Nuclear receptors in human immune cells: Expression and correlations. Mol Immunol

75. Inadera, H., Shimomura, A. (2005) Environmental chemical tributyltin augments adipocyte differentiation. Toxicol Lett 159, 226-234.

76. Chung, S.W., Kang, B.Y., Kim, T.S. (2003) Inhibition of interleukin-4 production in CD4+ T cells by peroxisome proliferator-activated receptor-gamma (PPAR-gamma) ligands: involvement of physical association between PPAR-gamma and the nuclear factor of activated $\mathrm{T}$ cells transcription factor. Mol Pharmacol 64, 1169-1179.

77. Clark, R.B. (2002) The role of PPARs in inflammation and immunity. J Leukoc Biol 71, 388-400.

78. Faveeuw, C., Fougeray, S., Angeli, V., Fontaine, J., Chinetti, G., Gosset, P., Delerive, P., Maliszewski, C., Capron, M., Staels, B., Moser, M., Trottein, F. (2000) Peroxisome proliferator-activated receptor gamma activators inhibit interleukin-12 production in murine dendritic cells. FEBS Lett 486, 261-266.

79. Gosset, P., Charbonnier, A.S., Delerive, P., Fontaine, J., Staels, B., Pestel, J., Tonnel, A.B., Trottein, F. (2001) Peroxisome proliferator-activated receptor gamma activators affect the maturation of human monocyte-derived dendritic cells. Eur J Immunol 31, 2857-2865.

80. Nencioni, A., Wesselborg, S., Brossart, P. (2003) Role of peroxisome proliferator-activated receptor gamma and its ligands in the control of immune responses. Crit Rev Immunol 23, 1-13.

81. Yang, Y., Eggertsen, G., Gafvels, M., Andersson, U., Einarsson, C., Bjorkhem, I., Chiang, J.Y. (2004) Mechanisms of cholesterol and sterol regulatory element binding protein regulation of the sterol 12alphahydroxylase gene (CYP8B1). Biochem Biophys Res Commun 320, 1204-1210.

82. Xu, C., Li, C.Y., Kong, A.N. (2005) Induction of phase I, II and III drug metabolism/transport by xenobiotics. Arch Pharm Res 28, 249-268.

83. Fletcher, N., Wahlstrom, D., Lundberg, R., Nilsson, C.B., Nilsson, K.C., Stockling, K., Hellmold, H., Hakansson, H. (2005) 2,3,7,8-Tetrachlorodibenzo-p-dioxin (TCDD) alters the mRNA expression of critical genes associated with cholesterol metabolism, bile acid biosynthesis, and bile transport in rat liver: a microarray study. Toxicol Appl Pharmacol 207, 1-24.

84. Riddick, D.S., Lee, C., Bhathena, A., Timsit, Y.E., Cheng, P.Y., Morgan, E.T., Prough, R.A., Ripp, S.L., Miller, K.K., Jahan, A., Chiang, J.Y. (2004) Transcriptional suppression of cytochrome P450 genes by endogenous and exogenous chemicals. Drug Metab Dispos 32, 367-375.

85. Handschin, C., Meyer, U.A. (2005) Regulatory network of lipid-sensing nuclear receptors: roles for CAR, PXR, LXR, and FXR. Arch Biochem Biophys 433, 387-396.

86. Fielden, M.R., Zacharewski, T.R. (2001) Challenges and limitations of gene expression profiling in mechanistic and predictive toxicology. Toxicol Sci 60, 6-10.

87. Cunningham, M.L., Bogdanffy, M.S., Zacharewski, T.R., Hines, R.N. (2003) Workshop overview: use of genomic data in risk assessment. Toxicol Sci 73, 209-215.

88. Schmidt, C.W. (2002) Toxicogenomics: an emerging discipline. Environ Health Perspect 110, A750-A755.

89. Bartosiewicz, M.J., Jenkins, D., Penn, S., Emery, J., Buckpitt, A. (2001) Unique gene expression patterns in liver and kidney associated with exposure to chemical toxicants. J Pharmacol Exp Ther 297, 895-905.

90. Hamadeh, H.K., Bushel, P., Paules, R., Afshari, C.A. (2001) Discovery in toxicology: mediation by gene expression array technology. J Biochem Mol Toxicol 15, 231-242.

91. Roberts, D.C. (2002) Biomarkers, yesterday, today and tomorrow: the basis for health claims. Asia Pac J Clin Nutr 11, S87-S89. 



\section{4}

\section{In vitro immunotoxicity of bis(tri-n-butyltin)oxide (TBTO) studied by toxicogenomics}

Toxicology (2007) 237: 35-48

K.A. Baken ${ }^{1,2}$

J. Arkusz ${ }^{3}$

J.L.A. Pennings ${ }^{2}$

R.J. Vandebriel ${ }^{2}$

H. van Loveren ${ }^{1,2}$

\footnotetext{
${ }^{1}$ Department of Health Risk Analysis and Toxicology, Maastricht University, Maastricht, The Netherlands ${ }^{2}$ Department of Toxicology, Pathology and Genetics, National Institute for Public Health and the Environment, Bilthoven, The Netherlands

${ }^{3}$ Department of Toxicology and Carcinogenesis, Nofer Institute of Occupational Medicine, Lodz, Poland
} 


\begin{abstract}
The biocide and environmental pollutant bis(tri- $n$-butyltin)oxide (TBTO) causes thymus atrophy in rodents. Whether the depletion of thymic lymphocytes by tributyltin compounds may be the result of inhibition of cell proliferation or induction of apoptosis is subject of debate. We examined gene expression profiles in primary rat thymocytes exposed to TBTO in vitro at dose levels of $0,0.1,0.3,0.5$, and $1.0 \mu \mathrm{M}$. By measuring cell viability and apoptosis, exposure conditions were selected that would provide information on changes in gene expression preceding or accompanying functional effects of TBTO. Several processes related to TBTO-induced toxicity were detected at the transcriptome level. Effects on lipid metabolisms appeared to be the first indication of disruption of cellular function. Many transcriptional effects of TBTO at higher dose levels were related to apoptotic processes, which corresponded to present or subsequent thymocyte apoptosis observed phenotypically. The gene expression profile was, however, not unambiguous since expression of apoptosis-related genes was both increased and decreased. Stimulation of glucocorticoid receptor signaling appeared to be a relevant underlying mechanism of action. These findings suggest that TBTO exerts its toxic effects on the thymus primarily by affecting apoptotic processes, but the possibility is discussed that this may in fact represent an early effect that precedes inhibition of cell proliferation. At the highest dose level tested, TBTO additionally repressed mitochondrial function and immune cell activation. Our in vitro toxicogenomics approach thus identified several cellular and molecular targets of TBTO that may mediate the toxicity towards thymocytes and thereby its immunosuppressive effects.
\end{abstract}




\section{Introduction}

Due to the direct toxicity toward bacteria and aquatic organisms, tributyltin (TBT) compounds have been used as biocides extensively [1]. As a result, these organotin compounds are widely spread in the environment. Immunosuppression is the critical toxicological endpoint of rodent exposure to bis(tri- $n$-butyltin)oxide (TBTO) [2,3]. The adverse effect of TBTO on the immune system is well established and comprises thymus involution as a consequence of depletion of cortical thymocytes, peripheral depletion of Tlymphocytes, a diminished cellular immune response, reduced natural killer (NK) cell and macrophage activity, and T helper (Th)2 polarization [4-12].

The mechanisms behind the immunosuppressive action of TBTO are not fully understood. A range of cellular effects of TBT compounds has been reported, including disruption of the cytoskeleton, perturbation of plasma membranes and membrane bound transporters, interruption of ion fluxes, a rise in the intracellular $\mathrm{Ca} 2+$ concentration, mitochondrial damage, disturbance of energy metabolism, production of reactive oxygen species, and inhibition of DNA, RNA, and protein synthesis $[6,13]$. The effects that most likely explain TBTO-induced thymus atrophy are inhibition of cell proliferation and induction of apoptosis in thymocytes. Inhibition of lymphocyte proliferation has been observed in vivo and in vitro [3, 14-17]. However, results of other studies pointed to induction of apoptosis by TBT [18-21]. Gennari and colleagues reported that low doses of tributyltin chloride inhibited immature thymocyte proliferation, whereas high doses induced apoptotic cell death [22].

Microarray analysis allows genome-wide assessment of effects of toxicants on gene expression and this technique thus makes simultaneous examination of a wide range of cellular effects feasible. In a previous study, we applied such a toxicogenomics approach to examine the effects of oral administration of TBTO on the gene expression profile in rodent thymuses, in order to investigate if the cellular effects and immunosuppressive action would be revealed this way and to elucidate the molecular mechanisms of action. One of the outcomes of the experiments in mice was suppression of cell proliferation-associated processes, whereas no distinct effects on (regulation of) apoptosis were found. In rat thymuses, hardly any gene expression changes were detected after TBTO exposure, even though atrophy of this organ was observed [23]. For a more in-depth investigation of the transcriptional events responsible for the TBTOinduced immunotoxicity in rats, gene expression profiles of primary rat thymocytes directly exposed to TBTO in vitro were examined in the present study. Disruption of cellular functioning was monitored by measuring viability and apoptosis, and based on the results thereof, experimental settings (dose and duration of exposure) yielding different degrees of cytotoxicity were established. Since changes in gene expression are assumed to precede cellular effects, microarray analysis was also performed at dose levels at which phenotypic effects of TBTO were still absent. The gene expression profiles observed in this early stage of toxicity are considered to be compound-specific [24]. Expression profiles in cells experiencing a loss of viability and more advanced toxicity were examined as well in order to gain insight into gene expression changes that contribute to disruption of thymocyte function by TBTO. 


\section{Materials and Methods}

\section{Thymocyte isolation}

Five male Wistar rats (RIV:TOX) bred specific pathogen free were obtained from the institute's own breeding colony and euthanized by $\mathrm{CO}_{2} / \mathrm{O}_{2}$ exposure without preceding treatment at the age of 5 weeks. The thymuses were excised aseptically and collected in 5 ml RPMI 1640 medium (Gibco, Invitrogen, Breda, The Netherlands) with 10\% heat inactivated Fetal Calf Serum (FCS) (PAA, Linz, Austria), $100 \mathrm{U} / \mathrm{ml}$ penicillin, and 100 $\mu \mathrm{g} / \mathrm{ml}$ streptomycin (Gibco) (standard medium) on ice. Single cell suspensions of the thymuses were prepared by pressing the organs through a $70 \mu \mathrm{m}$ nylon cell strainer (Falcon, Franklin Lakes, NJ). After centrifugation (10 min, $1200 \mathrm{rpm}, 4{ }^{\circ} \mathrm{C}$ ) the cell pellets were resuspended in $5 \mathrm{ml}$ of red blood cell lysis buffer $(\mathrm{NH} 4 \mathrm{Cl} 155 \mathrm{mM}, \mathrm{KHCO} 310 \mathrm{mM}$, EDTA $1 \mathrm{mM}$; pH 7.4), kept on ice for $5 \mathrm{~min}$, pelleted (5 min, $1200 \mathrm{rpm}, 4{ }^{\circ} \mathrm{C}$ ) and then washed twice in standard medium (10 min, $\left.1200 \mathrm{rpm}, 4{ }^{\circ} \mathrm{C}\right)$. A Coulter Counter (Z2; Coulter Electronics, Mijdrecht, The Netherlands) was used to count the cells and the concentrations of the cell suspensions were adjusted to $5 \times 10^{7}$ cells $/ \mathrm{ml}$ in standard medium with $20 \%$ FCS. Viability of the freshly isolated cells exceeded $96 \%$ as assessed by $0.4 \%$ Trypan Blue Stain (Gibco) exclusion testing. Each of the five cell suspension derived from the separate rats was then used for measurement of cell viability and apoptosis in varying TBTO exposure conditions, as well as RNA isolation and microarray analysis of these thymocytes. Thymuses of five other rats were used to repeat the viability analysis and part of the apoptosis measurements. The study was agreed upon by the institute's Ethical Committee on Experimental Animals, in accordance to national legislation.

\section{TBTO exposure}

Shortly before addition to the primary thymocyte cultures, bis(tri- $n$-butyltin)oxide ( $96 \%$ purity; Sigma-Aldrich, Zwijndrecht, the Netherlands) was dissolved in absolute ethanol and diluted in standard medium without FCS to final concentrations in the culture wells of 0 , $0.1,0.3,0.5$, and $1.0 \mu \mathrm{M}$. The final ethanol concentration in the cultures did not exceed $0.085 \%$, which had no effects on test system parameters.

\section{WST-1 assay}

Cell viability after TBTO exposure was determined by colorimetric measurement of WST-1 cleavage. In viable cells, mitochondrial dehydrogenases convert the tetrazolium salt WST1 to a water-soluble formazan dye which can be measured spectrophotometrically. For every TBTO concentration and the medium control, $1.67 \times 10^{6}$ cells of each of the five suspensions derived from separate rats were seeded in a flat-bottom 96-well plate (Greiner, Alphen aan den Rijn, The Netherlands) in quintuplicate (i.e. five wells per exposure condition and cell suspension). Cells were incubated with TBTO solutions or medium in a total volume of $100 \mu \mathrm{l}$ during 3 or $6 \mathrm{~h}$ at $37^{\circ} \mathrm{C}$ in a humidified atmosphere of $5 \% \mathrm{CO}_{2}$. During the (final) $3 \mathrm{~h}$ of exposure, $10 \mu \mathrm{l} /$ well of WST solution (WST-1 and an electron coupling reagent; Roche, Woerden, The Netherlands) was present. WST-1 
cleavage was quantified at $450 \mathrm{~nm}$ using a microplate reader (FLUOstar Galaxy and software v4.30-0; BMG Labtechnologies, Offenburg, Germany). For each thymocyte suspension (biological replicates), the mean optical density (OD) of the five technical replicates per exposure condition was compared to the mean OD of the appropriate controls to calculate the relative viability. This assay was performed once using the same primary cell suspensions as were used for RNA isolation, and repeated using thymocytes obtained from 5 other rats.

\section{Annexin $V$ and Pl staining}

Occurrence of apoptosis and cell death after TBTO exposure were examined by Annexin $\mathrm{V}$ and propidium iodide (PI) cell staining using the ApoAlert Annexin V-FITC Apoptosis kit (BD Biosciences, Alphen aan den Rijn, The Netherlands) and FACS analysis (FACSCalibur and CellQuest Pro software v5.2.1; BD Biosciences). Per dose of TBTO, 1 $\mathrm{ml}$ of each of the fresh thymocyte suspensions derived from separate rats was seeded in a separate well of a 6-well plate (Greiner) and incubated with control medium or TBTO solution in a total volume of $3 \mathrm{ml}$ for 3 or $6 \mathrm{~h}$ at $37^{\circ} \mathrm{C}$ in a humidified atmosphere of $5 \%$ $\mathrm{CO}_{2}$. Then $60 \mu \mathrm{l}\left(1 \times 10^{6}\right.$ cells $)$ of each well was transferred to a tube and washed twice (5 min, $1200 \mathrm{rpm}, 4{ }^{\circ} \mathrm{C}$ ), once with PBS and once with Binding Buffer. Cell pellets were resuspended in Binding Buffer and stained according to the manufacturer's instructions. Annexin $\mathrm{V}$ was measured by FITC detection, while PI was measured by the PE emission detector. Unlabeled cells were considered to be viable, PI-positive cells to have lost viability, Annexin V-positive cells to be early-stage apoptotic, and cells positive for both labels to be in a late stage of apoptosis, necrotic, or dead. For each thymocyte suspension 10,000 cells were analyzed per exposure condition and the numbers of labeled cells measured were represented as percentages of the total number. FACS analysis was performed in both separate experiments.

\section{RNA isolation}

After taking out part of the cells for FACS analysis, the remaining thymocytes in the 6-well plates were transferred to separate tubes and washed with PBS ( $5 \mathrm{~min}, 1200 \mathrm{rpm}, 4{ }^{\circ} \mathrm{C}$ ). The cell pellets were resuspended in RLT lysis buffer (Qiagen, Venlo, The Netherlands) and stored at $-80{ }^{\circ} \mathrm{C}$ until further processing. Total RNA was isolated from the lysates using RNeasy mini kits (Qiagen) in combination with a DNase treatment (RNase-Free DNase Set, Qiagen) according to the manufacturer's instructions. The quantity of RNA in each sample was assessed spectrophotometrically (ND1000; NanoDrop Technologies, Wilmington, DE) and RNA integrity was determined by automated gel electrophoresis (Bioanalyzer 2100; Agilent Technologies, Amstelveen, The Netherlands). RNA samples were stored at $-80^{\circ} \mathrm{C}$.

\section{RNA amplification and labeling}

Based on the results of the viability and apoptosis assays, the exposure groups to be analyzed by gene expression profiling were chosen. Of the corresponding RNA samples (five replicates derived from separate rats per exposure condition) $1 \mu \mathrm{g}$ was amplified and 
purified using an Amino Allyl MessageAmp II aRNA Amplification kit (Ambion, Austin, TX) according to the manufacturer's instructions. A common reference pool was prepared by mixing equal amounts of amplified RNA (aRNA) of all control and TBTO-exposed samples. Sample and reference pool aRNA labeling and purification were also performed using the amplification kit. Cy5 (CyDye Post Labeling Reactive Dye Pack, Amersham Biosciences, Buckinghamshire, UK) was used to label $5 \mu \mathrm{g}$ of control and exposed sample aRNA and equal amounts of reference pool aRNA were labeled with Cy3 (Amersham) simultaneously. The CyDye coupling yield was determined spectrophotometrically using the ND1000. Volumes of labeled and purified sample and reference aRNA containing 150 pmol CyDye were then reduced to $9 \mu \mathrm{l}$ by vacuum drying (SpeedVac Sc110 with Refrigerated Condensation Trap Rt100; Savant, Thermo Electro Corporation, Breda, The Netherlands) after which aRNA was fragmented (RNA Fragmentation Reagents; Ambion). Each control or exposed sample was then combined with an aliquot of reference pool aRNA and the total volume was adjusted to $25 \mu$ l.

\section{Hybridization}

The Rat Array Ready Oligo Set v1.0 (Operon Biotechnologies GmbH, Cologne, Germany) containing 5,705 C6-amino-linked oligos representing rat genes was spotted in duplicate on silylated glass slides at the Utrecht University Medical Centre (The Netherlands). Pretreatment of the slides included successive washing in $0.2 \%$ SDS (Ambion), milliQ water, $0.25 \mathrm{~g}$ of sodiumborohydride (Sigma-Aldrich) in $75 \mathrm{ml}$ PBS and $25 \mathrm{ml}$ ethanol, $0.2 \%$ SDS, and milliQ. The slides were dried by centrifugation ( $2 \mathrm{~min}, 1000 \mathrm{rpm}$ ) and stored in a dark moisture- and dust-free exsiccator until further use. The slides were prehybridized at $42{ }^{\circ} \mathrm{C}$ for at least one $\mathrm{h}$ in $5 \mathrm{x}$ SSC (Invitrogen), 0.1\% SDS, and 1\% BSA (Sigma-Aldrich) dissolved in milliQ and sterilized by filtering through a 0.22 micron filter (Millipore, Amsterdam, The Netherlands). Just before hybridization, the slides were washed successively in milliQ and propanol and dried by centrifugation. The hybridization mixture consisted of $50 \%$ formamide, $10 x$ SSC, and $0.2 \%$ SDS, which was filtered through a 0.22 micron filter and preheated to $42{ }^{\circ} \mathrm{C}$. Then $0.2 \mu \mathrm{g} / \mu \mathrm{l}$ salmon sperm (Gibco) and 5.2 $\mathrm{pmol} / \mathrm{ml}$ of a Cy3-labeled 70-mer oligo complementary to a landmark control oligo [25] (Operon) were added. Of this hybridization mixture, $25 \mu \mathrm{l}$ was added to each aRNA sample, and the complete mixture was heated at $95^{\circ} \mathrm{C}$ for $5 \mathrm{~min}$. Finally, the mixture was pipetted onto a slide and spread evenly by application of a cover slip. The slides were incubated for $18 \mathrm{~h}$ at $42{ }^{\circ} \mathrm{C}$ in the dark in humid hybridization chambers (GeneMachines Genomic Solutions Ltd., Cambridgeshire, UK). Thereafter, the slides were washed twice for $5 \mathrm{~min}$ in $2 \mathrm{xSC} / 0.1 \% \mathrm{SDS}$ at $42{ }^{\circ} \mathrm{C}$, then once for $5 \mathrm{~min}$ in $0.1 \mathrm{xSSC} / 0.1 \% \mathrm{SDS}$, and finally twice for $1 \mathrm{~min}$ in $0.1 \times \mathrm{SSC}$.

\section{Scanning}

Immediately after centrifugation, the microarray slides were scanned randomly using the Scanarray 4000 XL (Perkin Elmer, Boston, MA) with appropriate laser and photo multiplier tube (PMT) settings. Array Vision software (Imaging Research, St. Catherines, Ontario, Canada) was used to determine Cy3 and Cy5 signal intensities for each separate spot and background noise. Quality control was performed on raw data by means of a scatter plot 
and MA-plot as well as a normal probability plot to assess signal distribution. All slides contained appropriate controls and blank spots, which were used for quality control but were not included in further analyses.

\section{Data analysis}

The cell viability data of both experiments were combined, and the same was done for the results of the apoptosis measurements. The significance of differences in mean percentages of viable or Annexin V- or PI-stained cells between TBTO-exposed samples and controls were determined by ANOVA using SPSS for Windows (significance level $p$ $=0.05$ ).

Raw microarray signal data were normalized in R (http://www.r-project.org) using a four-step approach of (1) natural log-transformation (2) quantile normalization of all scans (3) correcting the sample spot signal for differences in the corresponding reference spot signal between arrays (4) averaging data from replicate spots. This method is essentially comparable to global local regression (LOESS) normalization. Normalized data were visualized by Principal Component Analysis (PCA) for additional quality control. Significance of differences in gene expression between the experimental groups was calculated in $R$ with ANOVA. The false discovery rate (FDR) was calculated per gene according to Benjamini and Hochberg [26]. For each gene fold ratios (FRs) in gene expression between each experimental group and the respective control were determined by comparing the average normalized signal values per group. FDR and FR criteria were fixed to levels suitable for further analysis. Differentially expressed genes were clustered (based on Euclidian Distance and Ward linkage) using GeneMaths (Applied Maths, StMartens-Latem, Belgium). Functional annotation and Gene Ontology (GO) term enrichment were examined with the Expression Analysis Systematic Explorer (EASE, http://david.abcc.ncifcrf.gov/ease/ease.jsp) using a maximal FDR of 0.1. MetaCore (GeneGo, San Diego, CA) was used to identify and visualize the involvement of the differentially expressed genes in specific cellular pathways, and this was related to the total amount of genes involved in the particular pathway and in all the available pathways combined. 

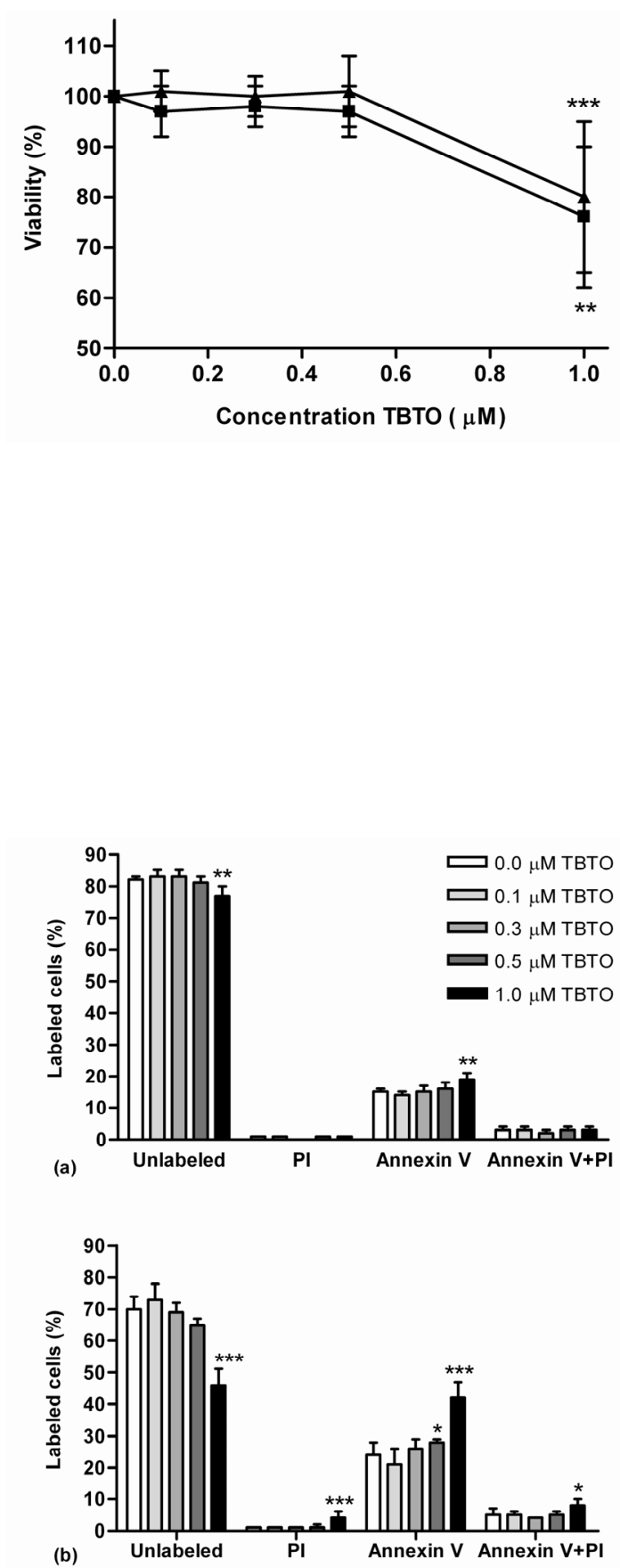

Figure 1.

Viability of primary rat thymocytes exposed to TBTO. Freshly isolated rat thymocyte suspensions $(n=10)$ were exposed to $0,0.1,0.3,0.5$, or $1.0 \mu \mathrm{M}$ TBTO during $3 \mathrm{~h}(\mathbf{\bullet})$ or $6 \mathrm{~h}(\mathbf{\Delta})$. Viability of the cells was determined by colorimetric measurement of WST-1 cleavage by mitochondrial enzymes. For each thymocyte suspension, the percentage of viable thymocytes at the different exposure conditions was determined by comparing the mean optical density (OD) to the mean OD of the appropriate controls. Thymocyte viability is expressed per exposure condition as mean percentage $\pm S D$. Significant differences from the control group are indicated by ** $(p<0.01)$ and ${ }^{* * *}$ $(p<0.001)$.

\section{Figure 2.}

Percentages of viable, apoptotic, or dead thymocytes after $3 \mathrm{~h}$ (a) or $6 \mathrm{~h}$ (b) of exposure to TBTO. Freshly isolated rat thymocyte suspensions were exposed to $0,0.1,0.3,0.5$, or $1.0 \mu \mathrm{M}$ TBTO during 3 $\mathrm{h}(\mathrm{n}=6)$ or $6 \mathrm{~h}(\mathrm{n}=3-4)$. Annexin $\mathrm{V}$ - and PIstaining of the cells and subsequent FACS analysis resulted in percentages of labeled cells corresponding to viability (unlabeled), loss of viability (PI), earlystage apoptosis (Annexin V), and latestage apoptosis, necrosis, or cell death (Annexin $\mathrm{V}+\mathrm{PI}$ ). Results are presented as means $\pm S D$. Significant differences from the control group are indicated by * $(p<0.05),{ }^{* *}(p<0.01)$, and ${ }^{* * *}(p<0.001)$. 


\title{
Results
}

\author{
Viability
}

The extent of WST-1 cleavage by mitochondrial enzymes in TBTO-exposed thymocyte cultures compared to controls was used as a measure of cell viability. Figure 1 shows the mean percentages of viable thymocytes $\pm S D$ after $3 \mathrm{~h}$ or $6 \mathrm{~h}$ of exposure to a dose range of TBTO. Thymocyte viability was significantly reduced compared to the control group after $3 \mathrm{~h}(80 \% ; \mathrm{p}<0.001)$ and $6 \mathrm{~h}(76 \% ; \mathrm{p}=0.001)$ of exposure to the highest dose of $1.0 \mu \mathrm{M}$ TBTO. Lower doses did not result in overt loss of viability, and at all dose levels the viability was comparable after both exposure periods.

\section{Apoptosis and cell death}

The effects of TBTO on the occurrence of apoptosis or cell death were examined by FACS analysis of Annexin V-and PI-stained thymocytes. After $3 \mathrm{~h}$ of exposure to 0-0.5 $\mu \mathrm{M}$ TBTO, $81-83 \%$ of the thymocytes were unlabeled and therefore viable, whereas $14-16 \%$ of the cells were in the early stage of apoptosis. The highest dose of $1.0 \mu \mathrm{M}$ TBTO caused a significant reduction in the percentage of unlabeled cells $(p=0.002)$ and increase in earlystage apoptosis $(p=0.004)$ compared to the control group. Thymocytes that had lost viability, or that were late stage-apoptotic or dead were virtually absent at all dose levels after $3 \mathrm{~h}$. When the thymocytes were exposed to $0-0.5 \mu \mathrm{M}$ TBTO for $6 \mathrm{~h}$, the percentages of unlabeled cells were reduced to $65-73 \%$. Similar to the earlier time point, these doses of TBTO did not affect viability or late-stage apoptosis or cell death at $6 \mathrm{~h}$ of exposure, whereas percentages of cells in both categories were increased significantly $(p<0.001$ and $p=0.020$, respectively) by the highest dose of $1.0 \mu \mathrm{M}$ TBTO. The percentage of early apoptotic cells was increased significantly by $0.5 \mu \mathrm{M}$ and $1.0 \mu \mathrm{M}$ TBTO $(p=0.035$ and $p$ $<0.001$, respectively) compared to the control group. Moreover, apoptosis was induced to a larger extent after $6 \mathrm{~h}$ of exposure to the highest TBTO dose than after $3 \mathrm{~h}$. These results are summarized in Figure 2.

\section{Gene expression}

Based on the viability and apoptosis assays, relevant dose levels and time points for microarray analysis were chosen. The dose of $0.3 \mu \mathrm{M}$ TBTO was the highest dose that did not show any decrease in cell viability or increase in apoptosis at both time points and was included to examine the gene expression profile in cells that phenotypically did not show an effect of TBTO after $3 \mathrm{~h}$ of exposure. $0.5 \mu \mathrm{M}$ TBTO was evaluated at the first time point to find gene expression changes that precede the phenotypic appearance of effects, since this dose induced apoptosis after $6 \mathrm{~h}$ of exposure. The dose of $1.0 \mu \mathrm{M}$ TBTO clearly affected cell viability and apoptosis in exposed thymocytes, and was analyzed at both time points since apoptosis was more advanced after $6 \mathrm{~h}$ than after $3 \mathrm{~h}$ of exposure and the second time point was thus expected to provide insight into gene expression changes related to the progression of the apoptotic process.

PCA could not distinguish the control and $0.3 \mu \mathrm{M}$ TBTO-exposed samples, but did discriminate the other groups and time points (data not shown). Besides, it showed 
that the microarrays of one $0.3 \mu \mathrm{M}$ TBTO-exposed sample and two samples exposed to $1.0 \mu \mathrm{M}$ TBTO for $6 \mathrm{~h}$ were outliers and these were rejected from further analysis. Gene expression data of the three groups exposed to TBTO for $3 \mathrm{~h}$ were compared to those of the corresponding control group by ANOVA, and the data after $6 \mathrm{~h}$ of exposure to the highest dose to the control group for this time point. For each time point, an FDR of $<0.1$ and an FR of $\leq-1.5$ or $\geq 1.5$ between exposed and control groups were applied to select differentially expressed genes. This yielded 349 regulated genes after exposure to one or more doses of TBTO for $3 \mathrm{~h}$, and 164 genes of which the expression had changed after 6 $\mathrm{h}$ of exposure to the highest dose. In total, 483 genes were differentially regulated in one or more of the exposure groups studied. The clustering of these hits is presented in Figure 3 and shows seven categories of gene regulation: $A$. down-regulation by $0.5 \mu \mathrm{M}$ TBTO at $3 \mathrm{~h}$; B. down-regulation by $0.5 \mu \mathrm{M}$ TBTO at $3 \mathrm{~h}$ and $1.0 \mu \mathrm{M}$ TBTO at $6 \mathrm{~h}$; C. dosedependent down-regulation; $D$. dose-dependent up-regulation; $E$. early dose-dependent up-regulation; F. late dose-dependent up-regulation; G. moderate up-regulation. The raw and normalized microarray data as well as a list of the differentially expressed genes and corresponding FRs and clusters are online provided as Supplementary Data at http://www.sciencedirect.com (doi:10.1016/j.tox.2007.04.018).

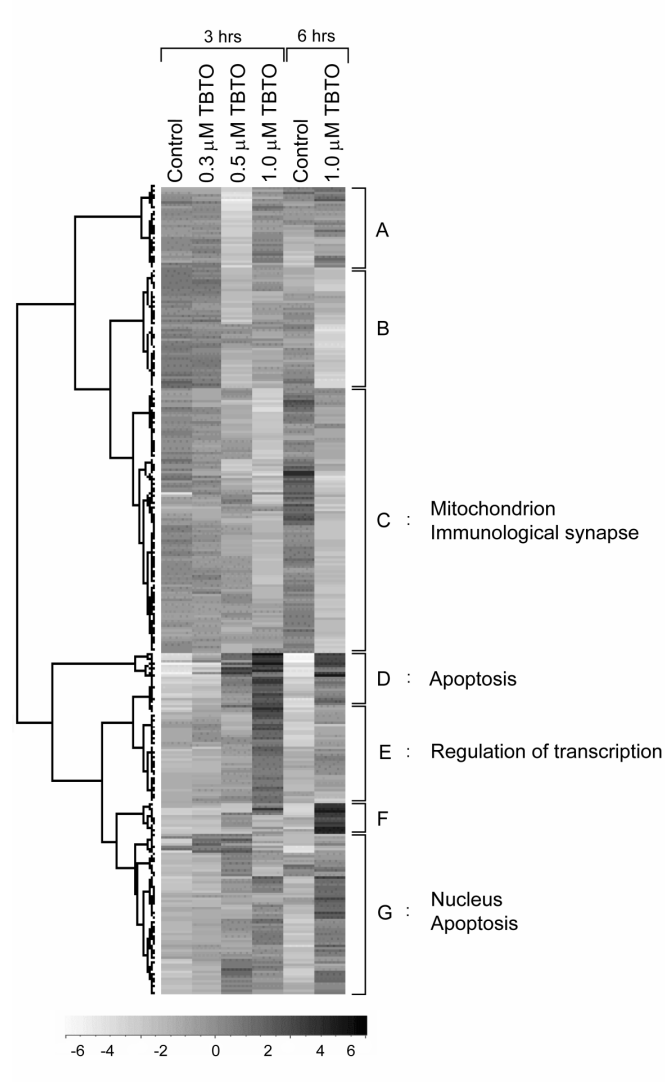

Figure 3.

Clustering of the 483 genes differentially expressed in primary rat thymocytes exposed to TBTO. Freshly isolated thymocyte suspensions were exposed to $0,0.3,0.5$, or $1.0 \mu \mathrm{M}$ TBTO for $3 \mathrm{~h}$ or to $1.0 \mu \mathrm{M}$ TBTO for 6 h. Per exposure group or time-matched control group, 5 RNA samples, each obtained from thymocytes of a different rat, were analyzed using microarrays comprising 5,705 oligos representing rat genes spotted in duplicate. For each time point, an FDR of $<0.1$ and a FR of $\leq-1.5$ or $\geq 1.5$ between exposed and control groups were applied to select differentially regulated genes. Gene expression levels are indicated by the bar and corresponding FRs: white represents downregulation and black up-regulation. Seven categories of gene regulation can be distinguished: $A$. down-regulation by $0.5 \mu \mathrm{M}$ TBTO at $3 \mathrm{~h}$; B. down-regulation by $0.5 \mu \mathrm{M}$ TBTO at $3 \mathrm{~h}$ and $1.0 \mu \mathrm{M}$ TBTO at $6 \mathrm{~h}$; C. dose-dependent down-regulation; $D$. dosedependent up-regulation; E. early dosedependent up-regulation; $F$. late dosedependent up-regulation; G. moderate upregulation. Enrichment of Gene Ontology terms (FDR <0.1) is indicated next to the clusters containing most of the corresponding genes. 


\section{Pathway regulation}

The differentially expressed genes are enriched for several GO terms, that are shown in Figure 3 next to the clusters in which these terms are over-represented. A significantly large proportion of the dose-dependently down-regulated hits (cluster $\mathrm{C}$ ) are involved in mitochondrial functioning. These genes mostly have a role in oxidative phosphorylation (such as cytochrome $\mathrm{c}$ oxidase and ATP synthase subunits) or fatty acid $\beta$-oxidation pathways. Cluster $C$ also showed over-representation of genes associated with the immunological synapse. In cluster E, comprising genes that were up-regulated at the early time point, regulation of transcription appeared to be affected. An enrichment of (anti)apoptosis-related genes was found in clusters $D$ and $G$, the clusters of dose-dependently and moderately up-regulated genes, respectively. The latter cluster also showed enrichment for genes that are associated with the nucleus. With the exception of apoptosis-related genes, Table 1 shows genes that are related to the processes mentioned above and are known to be associated with effects of TBTO or involved in specific pathways regulated by TBTO. Since genes involved in positive as well as negative regulation of apoptosis were up- or down-regulated by TBTO and these are present in various clusters, Table 2 gives an overview of the differentially regulated apoptosis-related genes not only in clusters $D$ and $G$, but in the whole set of differentially expressed genes.

MetaCore analysis of all clusters together showed that after $3 \mathrm{~h}$ of exposure, differentially expressed genes mostly had a role in pathways involved in lipid transport and metabolism and in anti-apoptotic processes. Of the specific cellular pathways involving a large part of the hits, the one in which relatively the most genes were regulated was glucocorticoid receptor signaling, and most of the genes involved were up-regulated (Figure 4). Other pathways with a high ranking were regulation of fatty acid biosynthesis by Srepbf1 (stimulated by TBTO), acetyl-CoA carboxylation, TNF-related apoptosis, and interleukin (IL)-3 signaling (all stimulated as well as inhibited). When genes regulated at the different dose levels were analyzed separately, the lowest dose of $0.3 \mu \mathrm{M}$ turned out to primarily affect pathways involved in lipid metabolism. The apoptotic processes and glucocorticoid signaling appeared at $0.5 \mu \mathrm{M}$, and IL-2 and IL-3 release at $1.0 \mu \mathrm{M}$ TBTO. After $6 \mathrm{~h}$ of TBTO-exposure, cellular pathways involving regulated genes were more diverse. Several genes in fibroblast growth factor signaling were for instance downregulated, and some transcription factors regulating glutathione biosynthesis up-regulated. Other pathways affected at this time point were mainly related to apoptotic, metabolic, or cell cycle-related processes. Much pathway regulation occurred through differential expression of the protein kinases Akt1, Mapk1, and Mapk14, and the transcription factor Jun B, which are all involved in a wide variety of cellular processes. Overall, MetaCore analysis revealed few specific apoptotic pathways that were regulated by TBTO in all experimental settings. 
Table 1.

Cellular processes and compartments affected by TBTO in primary rat thymocytes.

\begin{tabular}{|c|c|c|c|c|c|c|}
\hline \multirow[b]{3}{*}{ GenBank } & \multirow[b]{3}{*}{ Symbol } & \multirow[b]{3}{*}{ Gene name } & \multicolumn{4}{|c|}{ FR } \\
\hline & & & \multicolumn{3}{|c|}{$3 \mathrm{~h}$} & \multirow{2}{*}{$\begin{array}{l}6 \mathrm{~h} \\
1.0 \\
\mu \mathrm{M}\end{array}$} \\
\hline & & & $\begin{array}{l}0.3 \\
\mu \mathrm{M}\end{array}$ & $\begin{array}{l}0.5 \\
\mu \mathrm{M}\end{array}$ & $\begin{array}{l}1.0 \\
\mu M\end{array}$ & \\
\hline & & Oxidative phosphorylation & & & & \\
\hline X15030 & Cox5a & cytochrome $\mathrm{c}$ oxidase, subunit $\mathrm{Va}$ & -1.2 & -1.2 & -1.5 & -1.6 \\
\hline NM_022503 & Cox7a3 & cytochrome c oxidase, subunit $7 a 3$ & 1.2 & -1.2 & -1.7 & -2.9 \\
\hline$\times 72757$ & Cox6a1 & cytochrome c oxidase, subunit Vla, polypeptide 1 & 1.0 & -1.2 & -1.4 & -1.6 \\
\hline X54510 & Atp5j & $\begin{array}{l}\text { ATP synthase, } \mathrm{H}+\text { transporting, mitochondrial F0 complex, } \\
\text { subunit F6 }\end{array}$ & -1.1 & -1.2 & -1.5 & -1.6 \\
\hline L19927 & Atp5c1 & $\begin{array}{l}\text { ATP synthase, } \mathrm{H}+\text { transporting, mitochondrial } \mathrm{F} 1 \text { complex, } \\
\text { a polypeptide } 1\end{array}$ & -1.1 & -1.1 & -1.6 & -1.7 \\
\hline \multirow[t]{2}{*}{ D13121 } & Atp5i & $\begin{array}{l}\text { ATP synthase, } \mathrm{H}+\text { transporting, mitochondrial F0 complex, } \\
\text { subunit } \mathrm{e}\end{array}$ & -1.1 & -1.2 & -1.4 & -1.7 \\
\hline & & Lipid metabolism & & & & \\
\hline NM_013013 & Psap & prosaposin & -1.3 & -1.5 & -2.7 & -1.7 \\
\hline X15958 & Echs1 & enoyl Coenzyme A hydratase, short chain, 1 , & -1.1 & -1.0 & -1.7 & -1.3 \\
\hline NM_013006 & Lypla1 & lysophospholipase 1 & -1.1 & -1.0 & -1.7 & -1.5 \\
\hline AF095449 & Hadhsc & L-3-hydroxyacyl-Coenzyme A dehydrogenase, short chain & 1.4 & 1.1 & -1.2 & -1.7 \\
\hline \multirow[t]{2}{*}{ NM_016986 } & Acadm & acetyl-coenzyme A dehydrogenase, medium chain & -1.0 & -1.3 & -1.3 & -2.1 \\
\hline & & Immunological synapse & & & & \\
\hline D13555 & $\mathrm{Cd} 3 z$ & CD3 antigen, zeta polypeptide & -1.1 & -1.1 & -1.7 & -1.3 \\
\hline NM_031539 & Cd8b & CD8 antigen, beta chain & -1.3 & -1.2 & -1.7 & -1.6 \\
\hline NM_013169 & Cd3d & CD3 antigen delta polypeptide & -1.2 & -1.0 & -1.7 & -1.9 \\
\hline AF084933 & RT1-Db1 & RT1 class II, locus Db1 & -1.1 & -1.2 & -1.6 & -1.4 \\
\hline \multirow[t]{2}{*}{ L23128 } & RT1-N3 & RT1 class lb gene, H2-TL-like, grc region (N3) & 1.1 & -1.1 & 1.0 & -1.7 \\
\hline & & Cell cycle & & & & \\
\hline NM_031762 & Cdkn1b & cyclin-dependent kinase inhibitor $1 \mathrm{~B}$ & $-1,0$ & $-1,7$ & 1,1 & $-1,1$ \\
\hline M81639 & Snn & Stannin & $-1,3$ & $-1,5$ & $-2,6$ & $-3,8$ \\
\hline D16237 & Cdc25b & Cell division cycle 25B & $-1,1$ & 1,2 & $-1,5$ & 1,0 \\
\hline NM_031020 & Mapk14 & P38 mitogen activated protein kinase & $-1,0$ & $-1,0$ & $-1,5$ & $-1,9$ \\
\hline NM_131902 & Cdkn2c & $\begin{array}{l}\text { Cyclin dependent kinase inhibitor 2C(p18, inhibits CDK4), } \\
\text { see also D5Lev19 }\end{array}$ & 1,0 & 1,0 & 1,1 & $-1,7$ \\
\hline NM_012766 & Ccnd3 & Cyclin D3 & $-1,0$ & 1,0 & $-1,0$ & $-2,3$ \\
\hline NM_019296 & Cdc2a & Cell division cycle control protein 2 & $-1,1$ & $-1,1$ & 1,1 & $-2,5$ \\
\hline \multirow[t]{2}{*}{ NM_022542 } & RhoB & RhoB gene & 1,1 & 1,6 & 1,6 & 1,3 \\
\hline & & Oxidative stress & & & & \\
\hline NM_012580 & Hmox1 & Heme oxygenase & 1,1 & 1,4 & 2,0 & 2,1 \\
\hline NM_017050 & Sod1 & Superoxide dismutase 1 , soluble & 1,0 & $-1,1$ & 1,0 & 3,1 \\
\hline \multirow[t]{2}{*}{ NM_031614 } & Txnrd1 & Thioredoxin reductase 1 & 1,1 & 1,3 & $-1,0$ & 3,3 \\
\hline & & Metabolism & & & & \\
\hline NM_019184 & Сур2c & $\begin{array}{l}\text { Cytochrome P450, subfamily IIC (mephenytoin 4- } \\
\text { hydroxylase) }\end{array}$ & 1,0 & 1,8 & 3,7 & 2,4 \\
\hline
\end{tabular}


Table 1, continued.

\begin{tabular}{|c|c|c|c|c|c|c|}
\hline & & Transcription & & & & \\
\hline NM_031628 & $\mathrm{Nr} 4 \mathrm{a} 3$ & nuclear receptor subfamily 4 , group A, member 3 & 1.0 & 2.0 & 3.4 & 2.1 \\
\hline NM_013086 & Crem & cAMP responsive element modulator & 1.3 & 1.8 & 3.1 & 2.6 \\
\hline NM_031789 & $\mathrm{Nfe} 2 \mathrm{I} 2$ & nuclear factor, erythroid derived 2, like 2 & 1.1 & 1.5 & 3.1 & 2.2 \\
\hline NM_024360 & Hes1 & hairy and enhancer of split 1 (Drosophila) & -1.3 & 1.9 & 2.9 & 1.5 \\
\hline NM_024403 & Atf4 & activating transcription factor 4 & 1.3 & 1.5 & 2.7 & 2.9 \\
\hline NM_021836 & Junb & Jun-B oncogene & 1.2 & 1.8 & 2.5 & 2.2 \\
\hline AB025017 & Zfp36 & zinc finger protein 36 & 1.1 & 1.5 & 2.5 & 1.5 \\
\hline AF016192 & Erg2 & $\begin{array}{l}\text { potassium voltage-gated channel, subfamily } \mathrm{H} \text { (eag- } \\
\text { related), member } 6\end{array}$ & 1.1 & 1.1 & 1.9 & 1.2 \\
\hline AJ276495 & Ccnh & cyclin $\mathrm{H}$ & 1.2 & 1.3 & 1.8 & 1.6 \\
\hline U51583 & Tcf8 & transcription factor 8 (represses interleukin 2 expression) & 1.0 & 1.2 & 1.7 & 1.1 \\
\hline NM_031139 & Usf2 & upstream transcription factor 2 & 1.0 & 1.2 & 1.7 & 1.4 \\
\hline D86580 & NrOb2 & nuclear receptor subfamily 0 , group B, member 2 & 1.1 & 1.2 & 1.6 & 1.3 \\
\hline NM_012551 & Egr1 & early growth response 1 & 1.1 & 1.2 & 1.6 & 1.3 \\
\hline AY024364 & Gata3 & GATA binding protein 3 & 1.0 & 1.1 & 1.5 & -1.1 \\
\hline & & Nucleus & & & & \\
\hline AF286470 & Srebf1 & sterol regulatory element binding factor 1 & 3.0 & 3.2 & 2.2 & 2.4 \\
\hline NM_012591 & Irf1 & interferon regulatory factor 1 & 1.9 & 1.3 & 1.3 & 2.1 \\
\hline AF013144 & Cpg21 & dual specificity phosphatase 5 & 1.2 & 2.0 & 1.7 & 2.1 \\
\hline U09229 & Cutl1 & cut-like 1 (Drosophila) & -1.0 & 1.7 & 1.1 & -1.1 \\
\hline NM_023989 & Senp2 & SUMO/sentrin specific protease 2 & 1.1 & 1.6 & 1.5 & -1.0 \\
\hline NM_024351 & $\mathrm{Hsc70}$ & heat shock protein 8 & 1.0 & 1.6 & 1.0 & 4.1 \\
\hline NM_019242 & Ifrd1 & interferon-related developmental regulator 1 & 1.1 & 1.6 & 1.3 & 1.7 \\
\hline NM_031143 & Dgkz & diacylglycerol kinase zeta & 1.0 & 1.6 & 1.4 & -1.1 \\
\hline NM_012576 & $\mathrm{Nr} 3 \mathrm{c} 1$ & nuclear receptor subfamily 3 , group C, member 1 & 1.1 & 1.5 & 1.1 & 1.1 \\
\hline NM_031694 & Hsf2 & heat shock factor 2 & 1.1 & 1.5 & 1.3 & 1.1 \\
\hline AF279918 & Rgs2 & regulator of G-protein signaling 2 & -1.0 & 1.5 & 1.7 & 1.8 \\
\hline D12769 & Klf9 & basic transcription element binding protein 1 & 1.2 & 1.2 & 2.7 & 2.8 \\
\hline NM_022380 & Stat5b & signal transducer and activator of transcription $5 \mathrm{~B}$ & 1.1 & 1.4 & 1.7 & 1.7 \\
\hline NM_145788 & Tank & TRAF family member-associated Nf-kappa B activator & -1.0 & 1.4 & 1.7 & 2.0 \\
\hline NM_031617 & Csnk1e & casein kinase 1 , epsilon & 1.2 & 1.4 & 1.6 & 1.7 \\
\hline NM_138523 & Pprf18 & PRP18 pre-mRNA processing factor 18 homolog (yeast) & 1.1 & 1.2 & 1.6 & 1.8 \\
\hline NM_133290 & Zfp36 & zinc finger protein 36 & 1.0 & 1.2 & 1.5 & 1.6 \\
\hline NM_022175 & Pem & placentae and embryos oncofetal gene & 1.1 & 1.0 & 1.2 & 2.4 \\
\hline AF220102 & IIf3 & interleukin enhancer binding factor 3 & -1.0 & 1.4 & 1.2 & 2.0 \\
\hline NM_012566 & Gfi1 & growth factor independent 1 & 1.1 & 1.2 & 1.1 & 1.9 \\
\hline NM_012756 & $\operatorname{lgf} 2 r$ & insulin-like growth factor 2 receptor & 1.0 & 1.0 & 1.1 & 1.6 \\
\hline NM_024148 & Apex & apurinic/apyrimidinic endonuclease 1 & -1.1 & -1.0 & 1.0 & 1.5 \\
\hline \multicolumn{7}{|c|}{$\begin{array}{l}\text { Microarray analysis of freshly isolated thymocytes exposed to } 0,0.3,0.5 \text {, or } 1.0 \mu \mathrm{M} \text { TBTO for } 3 \mathrm{~h} \text { or to } \\
1.0 \mu \mathrm{M} \text { TBTO for } 6 \mathrm{~h} \text { yielded a set of differentially expressed genes (FDR }<0.1 \text { and fold ratio FR } \leq-1.5 \\
\text { or } \geq 1.5 \text {, displayed in bold). Genes that are related to Gene Ontology terms for which significant } \\
\text { enrichment (FDR }<0.1 \text { ) was found, that are involved in specific pathways regulated by TBTO, or that } \\
\text { are known to be associated with effects of TBTO, are listed in this table. The FRs for the } \\
\text { corresponding genes are displayed as compared to the time-matched control group. }\end{array}$} \\
\hline
\end{tabular}




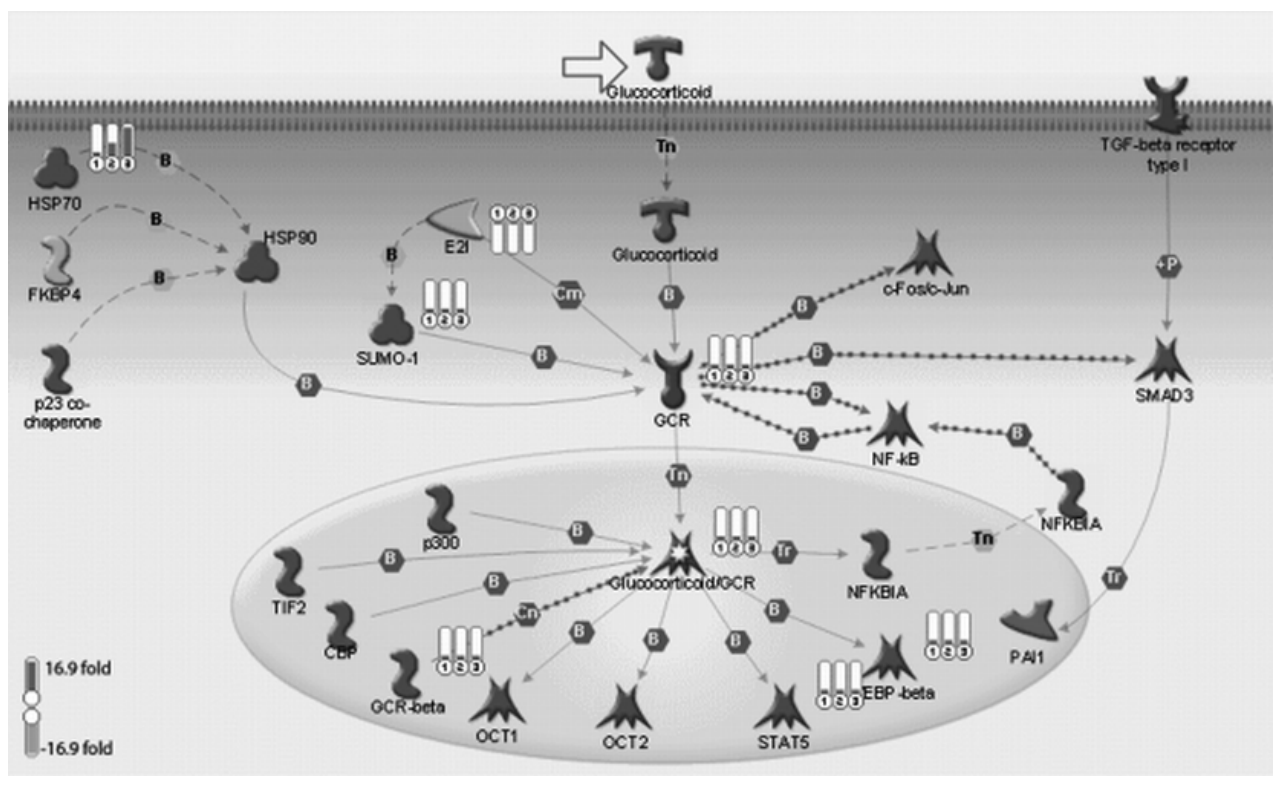

Figure 4.

Regulation of glucocorticoid receptor (GCR or Nr3c1) signaling TBTO in primary rat thymocytes. Upon ligand binding, the GCR translocates to the nucleus where it acts as a transcription factor, regulates the activity of other transcription factors, mainly by binding to them (indicated by a ' $\mathrm{B}$ ' in the arrows), and causes transcriptional activation ('Tr') of NF-KB1. This pathway included a relatively high number of differentially expressed genes detected by microarray analysis of freshly isolated thymocytes exposed to $0,0.3,0.5$, or $1.0 \mu \mathrm{M}$ TBTO during $3 \mathrm{~h}$. Involvement of regulated genes (FDR $<0.1$ and FR $\leq-1.5$ or $\geq 1.5$ ) in specific cellular pathways was identified and visualized using MetaCore. Up- or downregulation of hits compared to controls is indicated by the bars beside the genes; 1 . refers to the lowest dose, 2. to the intermediate dose, and 3. to the highest dose of TBTO. Arrows comprising a sign referring to the mechanism involved indicate a positive effect, dotted arrows a negative effect. For legend, see http://portal.genego.com/legends/legend_6.png. 
Table 2.

Genes involved in (regulation of) apoptosis affected by TBTO in primary rat thymocytes.

\begin{tabular}{|c|c|c|c|c|c|c|}
\hline \multirow[b]{3}{*}{ GenBank } & \multirow[b]{3}{*}{ Symbol } & \multirow[b]{3}{*}{ Gene name } & \multicolumn{4}{|c|}{ FR } \\
\hline & & & \multicolumn{2}{|c|}{$3 \mathrm{~h}$} & \multirow[b]{2}{*}{$1.0 \mu \mathrm{M}$} & \multirow{2}{*}{$\begin{array}{c}6 \mathrm{~h} \\
1.0 \mu \mathrm{M}\end{array}$} \\
\hline & & & $0.3 \mu \mathrm{M}$ & $\begin{array}{r}0.5 \\
\mathrm{MM}\end{array}$ & & \\
\hline & & Induction of apoptosis & & & & \\
\hline NM_024388 & $\mathrm{Nr} 4 \mathrm{a} 1$ & nuclear receptor subfamily 4 , group $A$, member 1 & 1.3 & 4.0 & 6.3 & 2.7 \\
\hline NM_012798 & Mal & myelin and lymphocyte protein & 1.1 & 2.3 & 4.0 & 2.5 \\
\hline AF-̄87065 & Ngfrap1 & nerve growth factor receptor (TNFRSF16) associated protein & -1.0 & 1.9 & 1.5 & 2.8 \\
\hline NM_031135 & Tieg & TGFB inducible early growth response & 1.4 & 1.9 & 2.5 & 2.0 \\
\hline NM_133392 & Stk17b & serine/threonine kinase 17b (apoptosis-inducing) & 1.0 & 1.7 & 2.1 & 1.5 \\
\hline NM_031328 & Bcl10 & B cell CLL/lymphoma 10 & 1.1 & 1.6 & 1.3 & 1.5 \\
\hline NM_024125 & Cebpb & CCAAT/enhancer binding protein (C/EBP), beta & 1.0 & 1.6 & 1.3 & 2.0 \\
\hline NM_012580 & Hmox1 & heme oxygenase (decycling) 1 & 1.1 & 1.4 & 2.0 & 2.1 \\
\hline AF036537 & Ripk3 & receptor-interacting serine-threonine kinase 3 & 1.2 & 1.0 & 1.8 & 1.4 \\
\hline NM_013199 & Dnm2 & dynamin 2 & 1.1 & 1.1 & 1.0 & 1.7 \\
\hline U77933 & Casp2 & caspase 2 & -1.0 & -1.1 & -1.7 & -1.6 \\
\hline M64300 & Mapk1 & mitogen activated protein kinase 1 & -1.1 & -1.4 & -1.7 & -2.2 \\
\hline NM_022684 & Bid & $\mathrm{BH} 3$ interacting domain death agonist & -1.1 & -1.3 & -2.0 & -1.1 \\
\hline NM_080888 & Bnip3l & BCL2/adenovirus E1B $19 \mathrm{kDa}$-interacting protein 3-like & -1.1 & -1.5 & -2.6 & -1.5 \\
\hline NM_022546 & Dapkl & Death-associated protein kinase 3 & 1.1 & -1.6 & -1.3 & -1.2 \\
\hline \multirow[t]{2}{*}{ NM_030826 } & Gpx1 & glutathione peroxidase 1 & -1.2 & -2.0 & -2.0 & -1.7 \\
\hline & & Inhibition of apoptosis & & & & \\
\hline NM_031971 & Hspa1a & heat shock $70 \mathrm{kD}$ protein $1 \mathrm{~A}$ & 1.7 & 3.3 & 11.1 & 13.6 \\
\hline NM_022231 & Birc4 & baculoviral IAP repeat-containing 4 & 1.3 & 3.4 & 6.4 & 4.6 \\
\hline NM_019142 & Prkaa1 & protein kinase, AMP-activated, alpha 1 catalytic subunit & 1.4 & 1.9 & 2.0 & 1.4 \\
\hline NM_013052 & Ywhah & $\begin{array}{l}\text { tyrosine } 3 \text {-monooxygenase/tryptophan } 5 \text {-monooxygenase } \\
\text { activation protein, eta polypeptide }\end{array}$ & 1.1 & 1.7 & 1.5 & 1.3 \\
\hline NM_024125 & Cebpb & CCAAT/enhancer binding protein (C/EBP), beta & 1.0 & 1.6 & 1.3 & 2.0 \\
\hline NM_031836 & Vegf & vascular endothelial growth factor $A$ & 1.1 & 1.2 & 1.9 & 1.2 \\
\hline NM_022380 & Stat5b & signal transducer and activator of transcription $5 \mathrm{~B}$ & 1.1 & 1.4 & 1.7 & 1.7 \\
\hline NM_012699 & Dnajb9 & DnaJ (Hsp40) homolog, subfamily B, member 9 & 1.1 & 1.4 & 1.7 & 2.0 \\
\hline NM_017050 & Sod1 & superoxide dismutase 1 & 1.0 & -1.1 & 1.0 & 3.1 \\
\hline NM_023987 & Birc3 & inhibitor of apoptosis protein 1 & 1.1 & 1.0 & 1.1 & 2.0 \\
\hline AF509819 & Tax1bp1 & Tax1 (human T cell leukemia virus type I) binding protein 1 & 1.2 & 1.1 & 1.3 & 1.9 \\
\hline AF321131 & Hdac3 & histone deacetylase 3 & -1.1 & 1.1 & -1.3 & -1.6 \\
\hline NM_017169 & $\operatorname{Prdx} 2$ & peroxiredoxin 2 & -1.1 & -1.1 & -1.3 & -1.6 \\
\hline D30040 & Akt1 & v-akt murine thymoma viral oncogene homolog 1 & -1.1 & 1.2 & -1.2 & -1.8 \\
\hline NM_022274 & Birc5 & baculoviral IAP repeat-containing 5 & -1.0 & 1.2 & 1.0 & -1.9 \\
\hline NM_012555 & Ets1 & v-ets erythroblastosis virus E26 oncogene homolog 1 (avian) & -1.1 & -1.1 & -1.6 & -1.4 \\
\hline U77933 & Casp2 & caspase 2 & -1.0 & -1.1 & -1.7 & -1.6 \\
\hline NM_016993 & $\mathrm{Bcl} 2$ & B cell leukemia/lymphoma 2 & -1.1 & -1.3 & -1.6 & -1.2 \\
\hline AW144637 & Son & Son cell proliferation protein & 1.1 & -1.5 & 1.2 & 1.7 \\
\hline NM_012992 & Npm1 & nucleophosmin 1 & -1.3 & -1.7 & -1.5 & 1.1 \\
\hline \multirow[t]{2}{*}{ NM_012673 } & Thy1 & thymus cell antigen 1 , theta & -1.1 & -1.8 & -1.4 & -2.6 \\
\hline & & Other apoptosis-related genes & & & & \\
\hline NM_024127 & Gadd45a & growth arrest and DNA-damage-inducible 45 alpha & 1.2 & -1.2 & 1.8 & 1.1 \\
\hline U77038 & Ptph6 & protein tyrosine phosphatase, non-receptor type 6 & 1.2 & 1.1 & 1.6 & -1.4 \\
\hline NM_017008 & Gapd & glyceraldehyde-3-phosphate dehydrogenase & -1.1 & -1.1 & -1.3 & -1.6 \\
\hline NM_031353 & Vdac1 & voltage-dependent anion channel 1 & -1.0 & -1.5 & -1.1 & -1.4 \\
\hline
\end{tabular}




\section{Discussion}

Gene expression profiles in isolated rat thymocytes were assessed by microarray analysis following treatment with several doses of TBTO for 3 or $6 \mathrm{~h}$. We first wished to establish whether exposure-related transcriptional effects could be detected in the absence of effects on cell viability and apoptosis. Therefore, we evaluated effects of exposure to 0.3 $\mu \mathrm{M}$ TBTO for $3 \mathrm{~h}$ on gene expression. Gene expression was only slightly influenced by this dose and the effects noticed were mostly related to lipid metabolism, which thus seems to be the first indication of disruption of cellular function by TBTO. Previously, we have detected regulation of lipid metabolism by TBTO by gene expression profiling also in murine thymuses and rat livers in vivo, and interference of TBT with this process has been reported by others as well $[23,27,28]$. However, while in the present study an up-regulation of Srebf1 was found, this gene was down-regulated in rat livers in vivo. Although we did not detect modulation of expression of nuclear receptors involved in lipid metabolism including retinoid $X$ receptor $(R X R)$ in the present study, in theory activation of $R X R$ by TBTO may have caused the up-regulation of Srebf1. Others have described activation of this receptor by TBTO $[29,30]$ and in murine thymuses in vivo, RXR expression was also not regulated whereas transcription of several genes under control of this receptor was increased.

The gene expression profile at $0.3 \mu \mathrm{M}$ TBTO did not predict the cytotoxic effects that occurred at higher dose levels. The dose of $0.5 \mu \mathrm{M}$ TBTO induced apoptosis after $6 \mathrm{~h}$ of exposure without reducing cell viability, a finding that has been reported by others as well [19]. We measured induction of apoptosis by the highest dose of $1.0 \mu \mathrm{M}$ TBTO already after $3 \mathrm{~h}$ of exposure and more advanced apoptosis after $6 \mathrm{~h}$. In addition, evident reduction of thymocyte viability by this dose was detected in the WST-1 assay at both time points and by $\mathrm{PI}$ staining after $6 \mathrm{~h}$ of exposure.

In order to find gene expression changes that preceded the phenotypic appearance of effects after $6 \mathrm{~h}$ of exposure to the dose of $0.5 \mu \mathrm{M}$ TBTO, exposure at this dose for $3 \mathrm{~h}$ was included in the microarray analysis. Importantly, genes differentially expressed after $3 \mathrm{~h}$ of exposure were to a relatively large extent related to apoptotic processes. These genes may therefore be considered as early markers of induction of apoptosis by TBTO in primary rat thymocytes. One of the up-regulated genes was Nr4a1. This gene, also named Nur77, was found to be related to organotin-induced apoptotic cell death in vitro and in vivo by others as well [31]. Nevertheless, the gene expression profile did not merely point towards induction of apoptosis, since pro- as well as anti-apoptotic genes were both up- and down-regulated, even within apoptotic pathways. The same was true for the expression profile in thymocytes already displaying functional effects of exposure to the highest dose of TBTO. Therefore, although changes in gene expression may be related to functional effects of a compound, genes involved in a particular process do not necessarily need to be all up- or all down-regulated in order for the process to take place eventually.

An explanation for these ambiguous microarray results could be that the apoptotic processes take place in different cells than the anti-apoptotic events. FACS analysis showed that only a small percentage of the cells was apoptotic or dead. The remaining thymocytes may protect themselves from unwanted apoptosis by stimulating pro-survival pathways. The same is observed in healthy thymuses, where apoptosis is, 
amongst others, induced by glucocorticoid (GC) signaling [32]. Recently, organotins were found to interfere with a GC-converting enzyme which may cause elevated GC levels [33]. Since the glucocorticoid receptor (GCR) is under autoregulatory control, an elevated GC level may result in increased receptor levels [34]. In the present study, we detected upregulation of $\mathrm{Nr} 3 \mathrm{c} 1$ (which is synonymous to GCR) as well as modulation of expression of other genes involved in GCR signaling by the intermediate TBTO dose at the first time point. $\mathrm{Nr} 3 \mathrm{c} 1$ has also been reported to be up-regulated in a microarray study examining organotin-induced apoptosis in vivo [35]. Whether the increased GCR transcription in vitro is a direct effect of TBTO or is caused by alteration of hormone levels cannot be discriminated on the basis of the microarray data, but the latter mechanism is likely to be different between in vivo and in vitro settings. Transcription of NF-kB1 is known to be induced by GCR, and although this gene was not affected at the first time point, we did find increased levels of the gene transcript at the second time point, suggesting that this may indeed have resulted from GCR over-expression. The reduced $\mathrm{Bcl} 2$ level may also have been mediated by the GCR and has been described to be involved in GCR-induced disruption of mitochondrial integrity [36]. Other transcriptional changes reported to be directly mediated by GCR were not detected in the present study [37]. As was also indicated by the other apoptosis-related effects, this suggests that the gene expression profile provides clues to mechanisms of action but is not unequivocal. Degradation of Birc3 and Birc4 proteins has been reported to be mediated by GC action [37]. Hence, the upregulation of the encoding genes in our data set could be interpreted as a compensatory effect. IL-2 and IL-3 are known to induce pro-survival factors that counterbalance the proapoptotic action of GC [32]. The up-regulation of genes involved in release of these cytokines as was observed in the present study may therefore contribute to anti-apoptotic processes in a subset of the cells. Taken together, GCR signaling may be one of the transcriptional effects of TBTO that contributes to pro- and anti-apoptotic gene expression profile in the exposed thymocytes, which might represent a physiological phenomenon.

Apart from lipid metabolism and apoptosis, other processes were found to be affected by TBTO as well. The subset of early up-regulated genes was enriched for regulation of transcription. This may be explained by an increased need of the cells for proteins that are required to execute apoptotic processes or to counteract cellular damage. Interference of TBT with mitochondrial function and energy production was detected at the highest dose level tested and has also been reported previously [23]. Inhibition of oxidative phosphorylation, loss of ATP synthase activity, and reduction of cellular ATP levels were for instance reported to be a direct effect of TBTO by others, and these findings are now substantiated by down-regulation of related genes [6,38,39]. Mitochondrial dysfunction may also be related to apoptosis, and both processes produce reactive oxygen species which may explain the increased glutathione synthesis. This increase could be mediated by $\mathrm{Nfe} 2 \mathrm{l2}$, or $\mathrm{Nrf2}$, which protects cells against stress by inducing expression of cell survival-promoting genes. Sod1, Hmox1, and Txnrd1 are among these genes and they were up-regulated by TBTO [40]. Finally, reduced expression of CD3 and CD8 and MHC class I and II genes by the highest dose examined were detected. The down-regulation of cell surface receptors was also a clear effect of TBTO in the murine thymus in vivo, and it was argued that this may result in impaired T cell activation, which in turn may contribute to the immunosuppressive effect of TBTO [23]. Moreover, loss of these immunological synapse proteins may drive the thymocytes towards apoptosis and reduce their 
proliferative response in vivo. The overlap of our findings with results of previous studies confirms the applicability of in vitro toxicogenomics studies for investigating the effects of TBTO.

The in vitro experiments described here were designed to examine gene expression profiles in (pre-)apoptotic cells, and indeed, dose- and time-dependent regulation of apoptosis-related genes was detected. We did not find inhibition of cell proliferation pathways by TBTO at the transcriptome level in the present study, in contrast to the observations in the murine thymus in our previous in vivo study [23], and in contrast to earlier demonstration of inhibition of proliferation of rat thymocytes by TBTO in vitro [17]. However, some genes involved in regulation of both apoptosis and the cell cycle were differentially expressed, such as Bcl2. Another example is RhoB, which inhibits cell proliferation, stimulates apoptosis, and has been reported to be up-regulated by GC [41]. Stannin has been shown to be involved in trimethyltin toxicity [42] and was down-regulated dose-dependently by TBTO in the present study. It is located in mitochondrial membranes and has a role in sensing mitochondrial damage, progression of the cell cycle, and apoptosis [43]. In addition, some genes that are specifically cell cycle-related were differentially expressed. Cyclin D3 was for instance found to be down-regulated and can be repressed by GC, mediating GC-induced growth arrest [44]. Moreover, it was, among some other genes, also down-regulated by TBTO in our in vivo study and by several other immunotoxic compounds in a study by Patterson et al. $[23,45]$. Likewise, in the in vivo study in mice, we did not detect regulation of apoptotic pathways but regulation of a few genes involved in apoptosis [23]. For example, Cebpb, Bnip3I, and Birc5 were affected and regulation of these genes was also observed in the present study. Furthermore, Kishi and coworkers observed decreased thymus weights and an increase in apoptotic cells in rats exposed to dioctyltinchloride in vivo, whereas hardly any effects on apoptosis-related genes were found [35]. Lack of overt pathway regulation does therefore not exclude contribution of both processes to cytotoxicity due to TBTO.

The identification of different primary mechanisms of action of TBTO in vitro as compared to in vivo is most likely due to the experimental design. Firstly, it is possible that in vitro effects differ from in vivo effects intrinsically, as was also argued by Gennari et al. [22], and that cultured primary thymocytes are more susceptible to apoptotic cell death. But most importantly, the exposure time of the thymocytes was, although not directly comparable, much shorter in vitro (hours) than in vivo (days). Induction of apoptosis could therefore be an effect of TBTO that precedes reduced thymocyte proliferation in time. Indeed, regulation of cell cycle-related processes did not seem to appear until our second time point in vitro. Grundler and co-workers have also reported that apoptotic cell death is a very early effect of in vitro TBT exposure [20]. Occurrence of apoptosis already early after the start of TBTO exposure would mean that this effect may have come to an end and that apoptotic thymocytes may have been cleared 3 days after the start of TBTO exposure, explaining the relative absence of apoptosis-related transcriptional changes at all time points examined in vivo [23]. It would also explain the fact that TBTO did inhibit cell proliferation in primary rat thymocytes in vitro in previous experiments $[16,17]$ but did not change cell cycle-related processes at the transcriptome level significantly in our study, because the former was observed after $24 \mathrm{~h}$ incubation in the presence of mitogens. Furthermore, activation of the cell cycle by mitogens may facilitate detection of the antiproliferative effect of TBTO, and may reduce sensitivity to induction of apoptosis since 
proliferating thymocytes are less prone to undergo apoptosis [46]. In the present study, thymocytes were not cultured longer than $6 \mathrm{~h}$ because of reduced RNA yields after prolonged time periods, and in the absence of mitogens since stimulation of proliferation of thymocytes may induce a wide range of transcriptional effects. A gradual depletion of energy over time as a result of the inhibition of mitochondrial function, rendering execution of the apoptotic process impossible, may be a reason for a time-dependent change in the primary effect of TBTO.

In conclusion, our in vitro toxicogenomics approach succeeded to demonstrate several effects of TBTO that may contribute to its toxicity towards thymocytes, among which was the induction of apoptosis. Apoptosis of primary thymocytes exposed to TBTO was, though not unequivocally, accompanied by changes in expression of many apoptosis-related genes. The gene expression profile at an earlier time point, but not at a lower dose, than that at which phenotypical changes were observed, was indicative of subsequent apoptosis. Stimulation of glucocorticoid receptor signaling may be a relevant underlying mechanism. Although the involvement of the gene expression changes detected by our microarray analyses in TBTO-induced toxicity should be confirmed in future studies, for instance by measuring protein levels or by interfering with protein production using siRNA-based methods, the results point to induction of apoptosis as an early effect of exposure of isolated rat thymocytes to TBTO and demonstrate the possibility to integrate microarray analysis in immunotoxicological research.

\section{Acknowledgements}

We thank Hans Strootman and co-workers for providing the rat thymuses and Eric Gremmer for his assistance in the microarray analysis. Financial support by the Netherlands Toxicogenomics Centre is gratefully acknowledged. 


\section{References}

1. Fent, K. (1996) Ecotoxicology of organotin compounds. Crit Rev Toxicol 26, 1-117.

2. Snoeij, N.J., Penninks, A.H., Seinen, W. (1987) Biological activity of organotin compounds--an overview. Environ Res 44, 335-353.

3. Vos, J.G., De Klerk, A., Krajnc, E.I., Kruizinga, W., Van Ommen, B., Rozing, J. (1984) Toxicity of bis(tri-nbutyltin)oxide in the rat. II. Suppression of thymus-dependent immune responses and of parameters of nonspecific resistance after short-term exposure. Toxicol Appl Pharmacol 75, 387-408.

4. Whalen, M.M., Green, S.A., Loganathan, B.G. (2002) Brief butyltin exposure induces irreversible inhibition of the cytotoxic function on human natural killer cells, in vitro. Environ Res 88, $19-29$.

5. Bressa, G., Hinton, R.H., Price, S.C., Isbir, M., Ahmed, R.S., Grasso, P. (1991) Immunotoxicity of tri- $n$ butyltin oxide (TBTO) and tri- $n$-butyltin chloride (TBTC) in the rat. J Appl Toxicol 11, 397-402.

6. Boyer, I.J. (1989) Toxicity of dibutyltin, tributyltin and other organotin compounds to humans and to experimental animals. Toxicology 55, 253-298.

7. De Waal, E.J., Schuurman, H.J., Van Loveren, H., Vos, J.G. (1997) Differential effects of 2,3,7,8tetrachlorodibenzo-p-dioxin, bis(tri- $n$ - butyltin) oxide and cyclosporine on thymus histophysiology. Crit Rev Toxicol 27, 381-430.

8. Kato, T., Tada-Oikawa, S., Takahashi, K., Saito, K., Wang, L., Nishio, A., Hakamada-Taguchi, R., Kawanishi, S., Kuribayashi, K. (2006) Endocrine disruptors that deplete glutathione levels in APC promote Th2 polarization in mice leading to the exacerbation of airway inflammation. Eur J Immunol 36, 1199-1209.

9. Kergosien, D.H., Rice, C.D. (1998) Macrophage secretory function is enhanced by low doses of tributyltinoxide (TBTO), but not tributyltin-chloride (TBTCI). Arch Environ Contam Toxicol 34, 223-228.

10. Van Loveren, H., Krajnc, E.I., Rombout, P.J., Blommaert, F.A., Vos, J.G. (1990) Effects of ozone, hexachlorobenzene, and bis(tri- $n$-butyltin)oxide on natural killer activity in the rat lung. Toxicol Appl Pharmacol 102, 21-33.

11. Verdier, F., Virat, M., Schweinfurth, H., Descotes, J. (1991) Immunotoxicity of bis(tri- $n$-butyltin) oxide in the rat. J Toxicol Environ Health 32, 307-317.

12. Vos, J.G., De Klerk, A., Krajnc, E.I., Van Loveren, H., Rozing, J. (1990) Immunotoxicity of bis(tri- $n$ butyltin)oxide in the rat: effects on thymus-dependent immunity and on nonspecific resistance following longterm exposure in young versus aged rats. Toxicol Appl Pharmacol 105, 144-155.

13. EFSA (2004) Opinion of the Scientific Panel on Contaminants in the Food Chain on a request from the Commission to assess the health risks to consumers associated with exposure to organotins in foodstuffs. The EFSA Journal 102, 1-119.

14. Snoeij, N.J., Van lersel, A.A., Penninks, A.H., Seinen, W. (1986) Triorganotin-induced cytotoxicity to rat thymus, bone marrow and red blood cells as determined by several in vitro assays. Toxicology 39, 71-83.

15. Snoeij, N.J., Penninks, A.H., Seinen, W. (1988) Dibutyltin and tributyltin compounds induce thymus atrophy in rats due to a selective action on thymic lymphoblasts. Int J Immunopharmacol 10, 891-899.

16. Nakata, H., Sakakibara, A., Kanoh, M., Kudo, S., Watanabe, H., Nagai, N., Miyazaki, N., Asano, Y., Tanabe, S. (2002) Evaluation of mitogen-induced responses in marine mammal and human lymphocytes by in-vitro exposure of butyltins and non-ortho coplanar PCBs. Environ Pollut 120, 245-253.

17. Vandebriel, R.J., Spiekstra, S.W., Hudspith, B.N., Meredith, C., Van Loveren, H. (1999) In vitro exposure effects of cyclosporin A and bis(tri- $n$-butyltin)oxide on lymphocyte proliferation, cytokine (receptor) mRNA expression, and cell surface marker expression in rat thymocytes and splenocytes. Toxicology 135, 49-66.

18. Aw, T.Y., Nicotera, P., Manzo, L., Orrenius, S. (1990) Tributyltin stimulates apoptosis in rat thymocytes. Arch Biochem Biophys 283, 46-50.

19. Raffray, M., Cohen, G.M. (1991) Bis(tri-n-butyltin)oxide induces programmed cell death (apoptosis) in immature rat thymocytes. Arch Toxicol 65, 135-139.

20. Grundler, W., Dirscherl, P., Beisker, W., Marx, K., Stampfl, A., Maier, K., Zimmermann, I., Nusse, M. (2001) Early functional apoptotic responses of thymocytes induced by Tri- $n$-butyltin. Cytometry 44, 45-56.

21. Raffray, M., Cohen, G.M. (1993) Thymocyte apoptosis as a mechanism for tributyltin-induced thymic atrophy in vivo. Arch Toxicol 67, 231-236.

22. Gennari, A., Potters, M., Seinen, W., Pieters, R. (1997) Organotin-induced apoptosis as observed in vitro is not relevant for induction of thymus atrophy at antiproliferative doses. Toxicol Appl Pharmacol 147, 259-266.

23. Baken, K.A., Pennings, J.L.A., De Vries, A., Breit, T.M., Van Steeg, H., Van Loveren, H. (2006) Gene expression profiling of bis(tri- $n$-butyltin)oxide (TBTO) induced immunotoxicity in mice and rats. J Immunotoxicol 3, 227-244. 
24. Luebke, R.W., Holsapple, M.P., Ladics, G.S., Luster, M.I., Selgrade, M., Smialowicz, R.J., Woolhiser, M.R., Germolec, D.R. (2006) Immunotoxicogenomics: the potential of genomics technology in the immunotoxicity risk assessment process. Toxicol Sci 94, 22-27.

25. Van de Peppel, J., Kemmeren, P., Van Bakel, H., Radonjic, M., Van Leenen, D., Holstege, F.C. (2003) Monitoring global messenger RNA changes in externally controlled microarray experiments. EMBO Rep 4, 387-393.

26. Benjamini, Y., Hochberg, Y. (1995) Controlling the false discovery rate: a practical and powerful approach to multiple testing. J Roy Stat Soc B 57, 289-300.

27. Grun, F., Blumberg, B. (2006) Environmental obesogens: organotins and endocrine disruption via nuclear receptor signaling. Endocrinology 147, S50-S55.

28. Inadera, H., Shimomura, A. (2005) Environmental chemical tributyltin augments adipocyte differentiation. Toxicol Lett 159, 226-234.

29. Kanayama, T., Kobayashi, N., Mamiya, S., Nakanishi, T., Nishikawa, J. (2005) Organotin compounds promote adipocyte differentiation as agonists of the peroxisome proliferator-activated receptor gamma/retinoid $\mathrm{X}$ receptor pathway. Mol Pharmacol 67, 766-774.

30. Nishikawa, J., Mamiya, S., Kanayama, T., Nishikawa, T., Shiraishi, F., Horiguchi, T. (2004) Involvement of the retinoid $X$ receptor in the development of imposex caused by organotins in gastropods. Environ Sci Technol 38, 6271-6276.

31. Gennari, A., Bleumink, R., Viviani, B., Galli, C.L., Marinovich, M., Pieters, R., Corsini, E. (2002) Identification by DNA macroarray of nur77 as a gene induced by di-n-butyltin dichloride: its role in organotin-induced apoptosis. Toxicol Appl Pharmacol 181, 27-31.

32. Distelhorst, C.W. (2002) Recent insights into the mechanism of glucocorticosteroid-induced apoptosis. Cell Death Differ 9, 6-19.

33. Atanasov, A.G., Nashev, L.G., Tam, S., Baker, M.E., Odermatt, A. (2005) Organotins disrupt the 11 betahydroxysteroid dehydrogenase type 2-dependent local inactivation of glucocorticoids. Environ Health Perspect 113, 1600-1606.

34. Ramdas, J., Liu, W., Harmon, J.M. (1999) Glucocorticoid-induced cell death requires autoinduction of glucocorticoid receptor expression in human leukemic T cells. Cancer Res 59, 1378-1385.

35. Kishi, H., Nemoto, M., Enomoto, M., Shinoda, M., Kawanobe, T., Matsui, H. (2006) Acute toxic effects of dioctyltin on immune system of rats. Environ Toxicol Pharmacol 22, 240-247.

36. Almawi, W.Y., Melemedjian, O.K., Jaoude, M.M. (2004) On the link between Bcl-2 family proteins and glucocorticoid-induced apoptosis. J Leukoc Biol 76, 7-14.

37. Herold, M.J., McPherson, K.G., Reichardt, H.M. (2006) Glucocorticoids in T cell apoptosis and function. Cell Mol Life Sci 63, 60-72.

38. Snoeij, N.J., Van Rooijen, H.J., Penninks, A.H., Seinen, W. (1986) Effects of various inhibitors of oxidative phosphorylation on energy metabolism, macromolecular synthesis and cyclic AMP production in isolated rat thymocytes. A regulating role for the cellular energy state in macromolecular synthesis and cyclic AMP production. Biochem Biophys Acta 852, 244-253.

39. von Ballmoos, C., Brunner, J., Dimroth, P. (2004) The ion channel of F-ATP synthase is the target of toxic organotin compounds. Proc Natl Acad Sci U S A 101, 11239-11244.

40. Kensler, T.W., Wakabayashi, N., Biswal, S. (2007) Cell Survival Responses to Environmental Stresses Via the Keap1-Nrf2-ARE Pathway. Annu Rev Pharmacol Toxicol 47, 6.1-6.28.

41. Chen, Y.X., Li, Z.B., Diao, F., Cao, D.M., Fu, C.C., Lu, J. (2006) Up-regulation of RhoB by glucocorticoids and its effects on the cell proliferation and NF-kappaB transcriptional activity. J Steroid Biochem Mol Biol 101, 179-187.

42. Davidson, C.E., Reese, B.E., Billingsley, M.L., Yun, J.K. (2004) Stannin, a protein that localizes to the mitochondria and sensitizes NIH-3T3 cells to trimethyltin and dimethyltin toxicity. Mol Pharmacol 66, 855-863.

43. Billingsley, M.L., Yun, J., Reese, B.E., Davidson, C.E., Buck-Koehntop, B.A., Veglia, G. (2006) Functional and structural properties of stannin: roles in cellular growth, selective toxicity, and mitochondrial responses to injury. J Cell Biochem 98, 243-250.

44. Renner, K., Ausserlechner, M.J., Kofler, R. (2003) A conceptual view on glucocorticoid-Induced apoptosis, cell cycle arrest and glucocorticoid resistance in lymphoblastic leukemia. Curr Mol Med 3, 707-717.

45. Patterson, R.M., Germolec, D.R. (2006) Gene expression alterations in immune system pathways following exposure to immunosuppressive chemicals. Ann N Y Acad Sci 1076, 718-727.

46. Elmore, S.A. (2006) Enhanced histopathology of the thymus. Toxicol Pathol 34, 656-665. 



\title{
5
}

\section{(Overlapping gene expression profiles of model compounds provide opportunities for immunotoxicity screening}

Toxicology and Applied Pharmacology (2007) in press

\author{
K.A. Baken ${ }^{1,2}$ \\ J.L.A. Pennings ${ }^{2}$ \\ M.J. Jonker ${ }^{3}$ \\ M.M. Schaap ${ }^{2,4}$ \\ A. de Vries ${ }^{2}$ \\ H. van Steeg ${ }^{2,4}$ \\ T.M. Breit ${ }^{3}$ \\ H. van Loveren ${ }^{1,2}$
}

\footnotetext{
${ }^{1}$ Department of Health Risk Analysis and Toxicology, Maastricht University, Maastricht, The Netherlands

${ }^{2}$ Laboratory for Health Protection Research, National Institute for Public Health and the Environment, Bilthoven, The Netherlands ${ }^{3}$ MicroArray Department (MAD), University of Amsterdam, Amsterdam, The Netherlands ${ }^{4}$ Department of Toxicogenetics, Leiden University Medical Center, Leiden, The Netherlands
} 


\title{
Chapter 5
}

\begin{abstract}
In order to investigate immunotoxic effects of a set of model compounds in mice, a toxicogenomics approach was combined with information on macroscopical and histopathological effects on spleens and on modulation of immune function. Bis(tri- $n$ butyltin)oxide (TBTO), cyclosporin A (CsA), and benzo[a]pyrene (B[a]P) were administered to $\mathrm{C} 57 \mathrm{BL} / 6$ mice at immunosuppressive dose levels. Acetaminophen (APAP) was included in the study since indications of immunomodulating properties of this compound have appeared in the literature. TBTO exposure caused the most pronounced effect on gene expression and also resulted in the most severe reduction of body weight gain and induction of splenic irregularities. All compounds caused inhibition of cell division in the spleen as shown by microarray analysis as well as by suppression of lymphocyte proliferation after application of a contact sensitizer as demonstrated in an immune function assay that was adapted from the local lymph node assay. The immunotoxicogenomics approach applied in this study thus pointed to immunosuppression through cell cycle arrest as a common mechanism of action of immunotoxicants, including APAP. Genes related to cell division such as Ccna2, Brca1, Birc5, Incenp, and Cdkn1a (p21) were identified as candidate genes to indicate anti-proliferative effects of xenobiotics in immune cells for future screening assays. The results of our experiments also show the value of group wise pathway analysis for detection of more subtle transcriptional effects and the potency of evaluation of effects in the spleen to demonstrate immunotoxicity.
\end{abstract}




\section{Introduction}

For identification of immunotoxicological properties of chemicals, exposure of experimental animals to xenobiotics is usually followed by evaluation of body and organ weights, histopathological features of lymphoid organs and tissues, lymphoid cell populations, and immune function. A more recent method to study immunotoxicity is examination of changes in gene expression profiles in immunologically relevant organs, also referred to as immunotoxicogenomics [1,2]. Such transcriptional changes may provide more in-depth mechanistic information. In addition, examination of the effects of immunotoxic compounds with varying modes of action at the transcriptome level is expected to reveal gene expression responses that are shared by those compounds and that may thus be indicative of general immunotoxic processes. These might in the future be used in screening protocols to identify immunotoxic compounds, especially since the use of gene expression profiles or biomarkers may allow identification of toxic effects at an earlier time point than when traditional immunotoxicity tests are used and may facilitate comparisons between species and in vivo and in vitro settings. This concept formed the basis for the present study, in which we performed microarray analyses in spleens of C57BL/6 mice being exposed to the well known immunotoxic agents bis(tri- $n$-butyltin)oxide (TBTO), cyclosporin A (CsA), and benzo[a]pyrene (B[a]P).

TBTO has been used as a biocide and occurs as an environmental pollutant. It primarily causes thymus involution, resulting in peripheral $\mathrm{T}$ cell depletion and inhibiting cellular immune responses, but also affects NK and macrophage activity [3-6]. Inhibition of cell proliferation and induction of apoptosis in thymocytes are among the mechanisms of action reported for this compound [7-13]. CsA is an immunosuppressive drug used in clinical transplantation and in treatment of autoimmune and inflammatory diseases. CsA binds to cyclophilin, after which the complex binds and thereby inhibits calcineurin. This in turn inhibits cellular translocation of Nuclear Factor of Activated T cells (NFAT) and prevents its transcriptional effects. Interleukin (IL)-2 production, which is critical for $\mathrm{T}$ cell proliferation, is for instance blocked by CsA, but other cytokines, growth factors, signaling molecules, and transcription factors have been shown to be modulated by CsA as well $[14,15]$. CsA causes histopathological changes in the thymus, spleen, and lymph nodes, alters lymphocyte subpopulations in the spleen, and interferes with $\mathrm{T}$ cell function and antibody responses [16-18]. B[a]P is a polycyclic aromatic hydrocarbon (PAH) that is released in combustion processes. Consequences of $\mathrm{B}[\mathrm{a}] \mathrm{P}$ exposure for the immune system include atrophy or decreased cellularity in spleen, thymus, and bone marrow and a reduction of circulating red and white blood cells and immunoglobulins [19]. Effects of $\mathrm{B}[\mathrm{a}] \mathrm{P}$ or its reactive metabolites may be mediated by the aryl hydrocarbon receptor $(\mathrm{AhR})$, disruption of cell membranes, production of various interleukins, or alteration of intracellular calcium mobilization [20].

The three immunotoxic compounds were administered at maximum tolerated dose (MTD) levels and we have previously shown that these doses cause a comparable degree of suppression of the proliferative response of lymphocytes to a contact sensitizer in an adapted local lymph node assay (LLNA) applied as an immune function assay [21]. In the present study, histological irregularities and gene expression profiles induced by the immunotoxicants were assessed in the spleen. The spleen contains immune cells originating from the thymus, bone marrow, and lymph nodes, all of which have central 
roles in immune function, and allows interaction between the different cell types. Moreover, examination of this organ provides insight into effects occurring in peripheral lymphocytes, which is particularly relevant with respect to the development of screening systems since peripheral blood samples of these cells can relatively easily be obtained from rodents as well as humans. We have recently published the effects of TBTO on gene expression in the thymuses of the mice involved in the present study [22]. Our main findings were a reduction of expression of cell surface determinants on thymocytes and inhibition of cell proliferation by TBTO. This is in keeping with known effects of TBTO in this target organ, underlining the value of the toxicogenomics approach for demonstrating the outcome of exposure to this immunotoxicant.

In addition to the well-known immunotoxic chemicals also acetaminophen (APAP) was administered to another group of mice. APAP is known to cause hepatic toxicity at high dose levels due to glutathione depletion, protein binding, oxidative stress, mitochondrial dysfunction, and inflammatory processes [23,24]. Besides the hepatotoxic effects, a few indications of immunomodulating properties of APAP have appeared in the literature. For example, associations have been found between APAP use and increased sensitivity to or duration of infection [25,26]. In a double-blind, placebo-controlled trial, a suppressed specific antibody response and aggravation of symptoms of rhinovirus infection were shown at therapeutic dose levels [27]. Ueno et al. [28] were the first to perform animal experiments focused at immunosuppression by APAP. A reduced T celldependent antibody production, delayed type hypersensitivity response, and mixed lymphocyte reaction were detected after a single hepatotoxic dose of APAP in mice, and moreover the proliferative response of splenocytes and thymocytes to mitogens were found to be inhibited by APAP $[28,29]$. In order to further investigate the immunotoxic properties of APAP, we compared the effects of APAP with the effects of the three model compounds. Gene expression changes in murine spleens induced by the four different compounds were thus examined and overlapping and potentially discriminating pathways and genes identified. 


\section{Materials and Methods}

\section{Animals}

The experiments were performed with 8 weeks old male C57BL/6JIco mice from the institute's own breeding colony (originally obtained from Charles River, Sulzfeld, Germany). All animals were bred specific pathogen free and kept in macrolon cages under tightly controlled standardized conditions. The study was agreed upon by the institute's Ethical Committee on Experimental Animals, in accordance to national legislation.

\section{Oral xenobiotic exposure}

The experiment included 160 mice which were randomly divided into four treatment groups and a control group. The mice were fed pelleted control SRM-A food (supplied by Altromin, Lage, Germany) or similar food mixed with 300 ppm TBTO (Sigma-Aldrich, Zwijndrecht, The Netherlands), $500 \mathrm{ppm}$ CsA (kindly provided by Novartis Pharma AG, Basel, Switzerland), or $5000 \mathrm{ppm}$ APAP (Sigma-Aldrich) (all manufactured by Altromin). B[a]P (purpose-made by Serva, Heidelberg, Germany) was dissolved in $0.1 \mathrm{ml}$ sunflower oil and administered by gavage three times a week at a dose of $13 \mathrm{mg} / \mathrm{kg}$ body weight. The mice that received $\mathrm{B}[\mathrm{a}] \mathrm{P}$ orally had free access to standard food during the exposure period. All diets and water were supplied ad libitum. The doses of TBTO, CsA, and B[a]P administered corresponded to the maximum tolerated dose (MTD), defined as the dose that causes a $10 \%$ reduction in body weight gain along the growth curve compared to the control group. Since the growth of mice to which APAP was administered tended to increase, the MTD could not be established similarly to the other compounds and a toxic dose level was thus deduced from literature data. Each treatment group was subdivided into four groups $(n=8)$ to which the diet or $B[a] P$ was administered for $3,7,14$, or 28 days $(2,4,7$, or 13 gavage treatments for $\mathrm{B}[\mathrm{a}] \mathrm{P}$, respectively).

\section{Dissection and histopathology}

All mice were sacrificed at the final day of the exposure period. The animals were euthanized by $\mathrm{CO}_{2} / \mathrm{O}_{2}$ exposure, weighed, and exsanguinated. Macroscopical irregularities were recorded. The spleens of the mice exposed for 3,7 , or 14 days were collected in RNA stabilization reagent (RNAlater; Qiagen, Venlo, The Netherlands) immediately and stored at $4{ }^{\circ} \mathrm{C}$ until further processing. The spleens of the animals exposed for 28 days were collected and fixed in $4 \%$ neutral buffered formaldehyde and subsequently embedded in paraffin wax for routine histological evaluation. In addition, livers of APAPexposed mice were examined. $5 \mu \mathrm{m}$ sections were stained with haematoxylin and eosin (H\&E) and examined microscopically. For each exposure group, significant differences from the time-matched control group in relative weight gain over the exposure period were determined by ANOVA using SPSS for Windows with a significance level of $p=0.05$. 


\section{RNA isolation and processing}

Total RNA was isolated from spleens of all mice exposed for 3, 7, or 14 days using RNeasy midi kits (Qiagen) with an additional DNase treatment (RNase-Free DNase Set; Qiagen) according to the manufacturer's instructions. To start the procedure, whole spleens were placed in lysis buffer and disrupted and homogenized immediately using a rotor-stator homogenizer (Diax 900 10G, Heidolph, Schwabach, Germany). RNA yield in each sample was assessed spectrophotometrically (ND1000; NanoDrop Technologies, Wilmington, DE) and RNA integrity was determined by automated gel electrophoresis (Bioanalyzer 2100; Agilent Technologies, Amstelveen, The Netherlands). RNA samples were then precipitated by adding 0.1 volume of sodium acetate and 3 volumes of absolute ethanol and stored at $-80{ }^{\circ} \mathrm{C}$. Shortly before microarray analysis, the samples were centrifuged ( $45 \mathrm{~min}, 14000 \mathrm{rpm}, 4^{\circ} \mathrm{C}$ ) and the supernatants removed. Then the pellets were washed with $70 \%$ ethanol and resuspended in an amount of RNase free water (Qiagen) to obtain an RNA concentration of $2.5 \mu \mathrm{g} / \mu \mathrm{l}$. For each exposure group, 4 pooled RNA samples consisting of $10 \mu \mathrm{g}$ RNA of each of 2 individual samples were composed for further analysis. In addition, a reference pool of mouse embryo RNA was prepared similarly to the RNA samples.

\section{Labeling}

Microarray analyses were conducted according to standard procedures. In short, RNA was amplified using a commercial amplification kit (Amino Allyl MessageAmp aRNA kit, Ambion, Austin, TX). Labeling was performed with an indirect labeling method (Cyscribe Post Labeling kit, CyDye Post Labeling Reactive Dye Pack and Cyscribe GFX Purification kit; Amersham Biosciences, Buckinghamshire, UK), according to the manufacturer's instructions. Cy3 was used to label $3 \mu \mathrm{g}$ of sample aRNA, and equal amounts of reference pool aRNA were labeled with Cy5 simultaneously. The CyDye coupling yield was determined spectrophotometrically using the ND1000. Volumes of labeled and purified sample aRNA containing 150 pmol Cy3 and reference pool aRNA with 75 pmol Cy5 were each reduced to $9 \mu \mathrm{l}$ by vacuum drying, after which the aRNA was fragmented (RNA Fragmentation Reagents; Ambion). The volumes of the (reference) samples were subsequently adjusted to $26 \mu \mathrm{l}$ with milliQ water, and $1 \mu \mathrm{l}$ was used to examine quality using the Bioanalyzer. Finally, each sample was combined with a reference pool sample.

\section{Hybridization}

Microarray analysis was performed using a Mouse Sigma Compugen oligolibrary consisting of a selection of $11 \mathrm{~K}$ oligos representing 8054 unique genes with a bias towards immunological and toxicological relevance in duplicate. After spotting, the slides were placed in hot steam shortly and dried. Then the oligos were cross-linked by $150 \mathrm{~mJ}$ UV light. Just before hybridization of aRNA, the slides were prehybridized in 2x SSPE $/ 0.2 \%$ SDS (both Ambion) at $52{ }^{\circ} \mathrm{C}$ for $2 \mathrm{~h}$. To the $50 \mu \mathrm{l}$ of combined sample and reference pool, $50 \mu \mathrm{l}$ microarray hybridization mixture (Amersham) was added. Then $100 \mu \mathrm{l}$ of formamide (Sigma-Aldrich) was added and the samples were injected into the hybridization chamber of an automated slide processor (Lucidea SlidePro Hybridizer; Amersham). Sixteen $\mathrm{h}$ of 
incubation at $37{ }^{\circ} \mathrm{C}$ were followed by 10 min of washing in $1 \times$ SSC/0.2\% SDS, $10 \mathrm{~min}$ in $0.1 \times \mathrm{SSC} / 0.2 \% \mathrm{SDS}$, and $4 \mathrm{~min}$ in $0.1 \% \mathrm{SSC}$. Finally, the slides were flushed with milliQ and isopropanol (Sigma-Aldrich).

\section{Scanning}

Immediately after drying, the microarray slides were scanned using the Agilent G2565 microarray scanner. Array Vision software v6.0 (Imaging Research, St. Catherines, ON, Canada) was used to quantify Cy3 and Cy5 signal intensities for each separate spot as artifact removed densities.

\section{Data analysis and statistics}

The microarray data were processed using $\mathrm{R}$ (v2.2.1; http://www.r-project.org) and the Bioconductor MAANOVA package (v0.98.8; http://www.jax.org/staff/churchill/labsite/ software/Rmaanova). All slides were subjected to a set of quality control checks, i.e. visual inspection of the scans, pen grid plots to check consistent pen performance, testing against criteria for signal to noise ratios, testing for consistent performance of the labeling dyes, examination of the consistency among the replicated samples by principal components analysis (PCA), and visual inspection of pre- and post-normalized data with box plots and RI plots. After log2 transformation, the data were normalized by a spatial LOWESS smoothing procedure and replicate features were collapsed. The normalized data for each exposure group were examined by PCA.

Implications of the gene expression changes induced by the different compounds for biological processes were examined by performing a threshold-free group wise Gene Ontology (GO) term analysis using Rank GOstat (http://gostat.wehi.edu.au/cgibin/RankGoStat.pl) [30]. For this analysis, a Wilcoxon Signed Rank test was applied to the complete set of genes examined for each compound at the intermediate time point of 7 days of exposure, and GO terms with a false discovery rate (FDR) $<0.1$ were considered significant.

The gene expression data were also analyzed using a two stage mixed ANOVA model $[31,32]$ in order to find significantly regulated genes. First, array, dye, and array-bydye effects were modeled globally. Subsequently, the residuals from this first model were fed into the gene-specific model to fit treatment and spot effects on a gene-by-gene basis using a mixed model ANOVA. For each treatment group (TBTO, CsA, B[a]P, and APAP) a one way four factor ANOVA was performed to identify differential gene expression between the control group and the groups exposed for 3, 7, or 14 days. For hypothesis testing a permutation based F1 test was used, which does not require assumption of normal distribution of the data and is therefore more robust [33]. The p-values resulting from the permutation procedure were corrected for multiple testing by calculating the FDR [34]. Genes with an FDR $<0.1$ were considered significantly differentially expressed.

Differentially expressed genes were clustered (based on Euclidian Distance and Ward linkage) using GeneMaths (Applied Maths, St-Martens-Latem, Belgium). For these genes, functional annotation and GO term enrichment were examined with the Expression Analysis Systematic Explorer (EASE, http://david.abcc.ncifcrf.gov/ease/ease.jsp) using a maximal FDR of 0.1 . MetaCore (GeneGo, San Diego, CA) was used to identify and 
visualize the involvement of the differentially expressed genes in specific cellular pathways, and this was related to the total amount of genes involved in the particular pathway and in all the available pathways combined.

\section{Local Lymph Node Assay}

An adapted LLNA was performed to examine the effects on immune function of the dose of APAP used for gene expression analysis and a ten times lower dose of $500 \mathrm{ppm}$. The assay was performed in male and female C57BL/6 mice of 6-9 weeks old obtained from Charles River similarly to previous assessment of immunomodulation by TBTO, CsA, and $\mathrm{B}[\mathrm{a}] \mathrm{P}$ [21]. The C57BL/6 strain is not traditionally used in the LLNA, but was applied in our study in order to compare the effects measured using this assay with those measured by microarray analysis. Woolhiser et al. [35] showed that this strain is comparable to CBA mice with regard to Th1 responses, such as the response to DNCB. Moreover, here the LLNA was not used to study sensitizing properties of compounds applied to the ears of the mice, but to investigate suppressive effects of orally administered test compounds on the immune response to a known allergen.

In short, the mice were fed control food or the same food mixed with 500 or 5000 ppm APAP (manufactured by Altromin) during 4 weeks. Diets and water were given ad libitum. Four mice per exposure group were then treated topically on the dorsum of both ears for three consecutive days with $1 \%, 0.66 \%$, or $0.33 \%(w / v)$ DNCB $(2,4-$ dinitrochlorobenzene 98\%; Sigma-Aldrich) (25 $\mu \mathrm{l}$ ) dissolved in acetone:olive oil (4:1) (AOO) and eight mice were treated with the vehicle only. Three days after the final DNCB application, the mice were euthanized by $\mathrm{CO}_{2} / \mathrm{O}_{2}$ exposure and the auricular lymph nodes (LN) were excised. The $L N$ were pooled for each animal and weighed. Single cell suspensions were prepared (cell suspensions of $0 \%$ DNCB-treated animals were pooled because of insufficient cells numbers per animal), seeded in triplicate into 96-wells plates, and incubated with [methyl- ${ }^{3} \mathrm{H}$ ]-thymidine (Amersham). Subsequently, the cells were harvested, the $\left[{ }^{3} \mathrm{H}\right]$-thymidine activity was determined, and $\left[{ }^{3} \mathrm{H}\right]$-thymidine incorporation was calculated per set of $\mathrm{LN}$ by multiplying the mean of the measured counts per minute (cpm) per group by the mean total LN cell number per group \pm SEM. Statistical analysis was performed by one-way ANOVA and significant differences of the control group were determined with the Bonferroni post hoc test, using a significance level of $p=0.05$. 


\section{Results}

\section{Animal weights and splenic irregularities}

Table 1 shows the average growth reduction in all groups exposed to the test compounds, which is defined as the relative decrease in weight gain over the exposure period in the exposed mice compared to the time-matched control mice. In each group the average weight gain after exposure was smaller than that observed in untreated animals, with the exception of the groups exposed to APAP for 3 and 28 days. For one mouse exposed to CsA for 3 days and one for 28 days increased spleen size was noted, and the spleens of three mice exposed to APAP for 3 days showed hemorrhagic lesions macroscopically. All other macroscopic irregularities noted at dissection comprised a reduced organ size. In 7 out of 8 animals exposed to TBTO for 28 days splenic atrophy, defined as a reduced size of both the red and the white pulp, was observed histologically. No histological irregularities were observed in other spleens, nor in the livers of APAP-exposed mice.

\section{Table 1.}

Growth reduction and macroscopically and histologically observed irregularities in murine spleens after exposure to the test compounds.

\begin{tabular}{llcccc}
\hline Compound & Duration of exposure (days) & $\mathbf{3}$ & $\mathbf{7}$ & $\mathbf{1 4}$ & $\mathbf{2 8}$ \\
\hline \multirow{2}{*}{ TBTO } & Growth reduction (\%) & $16^{* * *}$ & $25^{* * *}$ & $26^{* * *}$ & $24^{* * *}$ \\
& Macroscopical irregularities (\#) & 3 & 6 & 7 & 8 \\
& Histological irregularities (\#) & $N A$ & $N A$ & $N A$ & 7 \\
\hline \multirow{2}{*}{ CsA } & Growth reduction (\%) & 2 & $12^{* *}$ & 7 & $10^{* *}$ \\
& Macroscopical irregularities (\#) & 2 & 0 & 0 & 1 \\
& Histological irregularities (\#) & $N A$ & $N A$ & $N A$ & 0 \\
\hline \multirow{2}{*}{ [a]P } & Growth reduction (\%) & 5 & 7 & $9^{*}$ & $18^{* * *}$ \\
& Macroscopical irregularities (\#) & 0 & 0 & 1 & 1 \\
& Histological irregularities (\#) & $N A$ & $N A$ & $N A$ & 0 \\
\hline \multirow{3}{*}{ APAP } & Growth reduction (\%) & - & 7 & 1 & - \\
& Macroscopical irregularities (\#) & 4 & 2 & 0 & 2 \\
\hline
\end{tabular}

Groups of mice $(n=8)$ were exposed to TBTO, CsA, B[a]P, or APAP in the diet for $3,7,14$, or 28 days. The relative growth reduction after exposure to the compounds was determined by dividing the average percentage of weight gain or loss over time in the exposed groups by that in the timematched control group. Significance levels are ${ }^{*}(p<0.05),{ }^{* *}(p<0.01)$, and ${ }^{* * *}(p<0.001)$. Macroscopic irregularities noted in the spleen at dissection were always a reduced organ size, except for one spleen in the CsA group at day 3 and one at day 28 (increased size) and three spleens in the APAP group at day 3 (hemorrhagic lesions). Histological irregularities in the TBTO group consisted of splenic atrophy. 


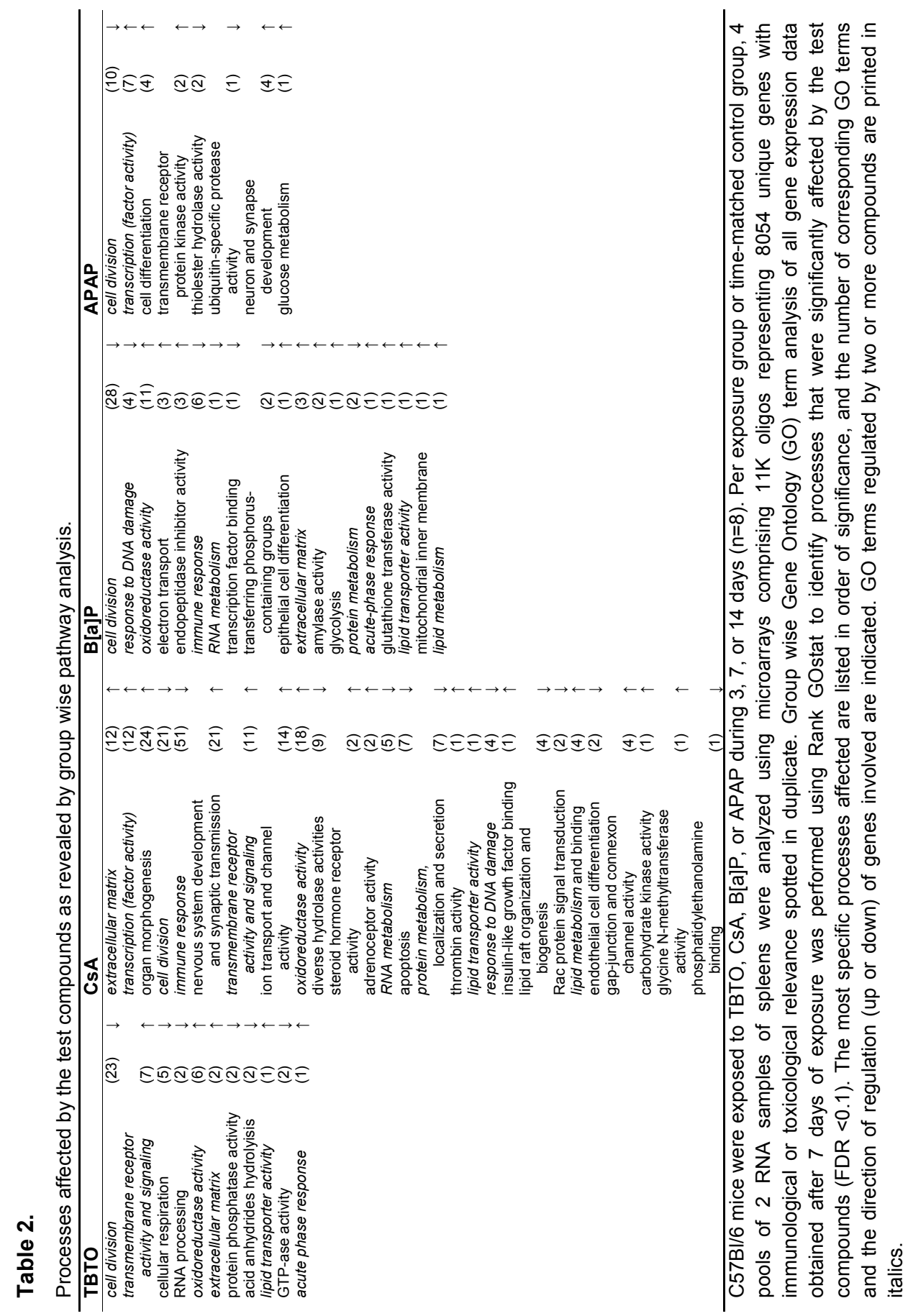




\section{Group wise Gene Ontology term analysis}

Group wise changes of GO terms in all genes examined after 7 days of exposure to each test compound were investigated by Rank GOstat. The GO terms that summarize the processes that appeared to be affected most are listed in Table 2. For the TBTO group the most pronounced effect was down-regulation of genes involved in cell division-related processes, which included DNA replication, mitosis, cytokinesis, cell cycle, and cyclindependent protein kinase regulator activity. Other examples of regulated processes are cellular respiration (including aerobic respiration, acetyl-CoA catabolism, and the tricarboxylic acid cycle), and up-regulation of genes related to oxidoreductase activity (including monooxygenase activity and tetrapyrrole and heme binding). A wide range of processes was found to be affected by CsA. Stimulation of morphogenesis and inhibition of cell division and of the immune response showed a high ranking and were represented by the largest number of GO terms. The latter process included antigen processing, presentation, and receptor signaling and $\mathrm{MHC}$ class II receptor activity; formation of immunological synapses; T cell differentiation and activation; humoral immune response; hemopoietic or lymphoid organ development; phagocytosis; immune cell migration including chemotaxis; inflammatory response; and cytokine production. The gene expression profile measured after 7 days of $B[a] P$ treatment showed, like that of TBTO and CsA, down-regulation of cell division-associated processes and up-regulation of oxidoreductase activity. It also repressed immune-related genes involved in $\mathrm{T}$ and $\mathrm{B}$ cell activation and proliferation. Other affected processes overlapping with the other compounds were for instance a reduced response to DNA damage (as in the CsA-induced gene expression profile) and increased expression of genes associated with the extracellular matrix (as found for TBTO and CsA as well). Group wise analysis of the complete gene expression profile for the APAP group revealed down-regulation of cell division as the most significantly regulated process.

\section{Differential gene expression}

Besides group wise regulation of GO terms, the microarray data for each exposure group were also analyzed for significant regulation of individual genes. First, PCA was performed on the normalized data, which discriminated the groups exposed to TBTO and APAP whereas the CsA and B[a]P groups appeared to be more similar to the controls (Figure 1). Since the average gene expression levels in the three time-matched control groups did not differ significantly, the data of all control samples were pooled. In the TBTO-exposed group, 206 genes were differentially expressed with an FDR $<0.1$ (112 down- and 94 upregulated). Of these genes, 51 were expressed with a fold ratio (FR) $\geq 2$ compared to the average control level (29 down- and 22 up-regulated). CsA and B[a]P exposure did not result in statistically significant differential expression of individual genes. In the group exposed to APAP, 326 genes were differentially expressed (169 down- and 157 upregulated), 25 of which with an $F R \geq 2$ (10 down- and 15 up-regulated). 34 genes showed significance in both the TBTO and the APAP group (11 of which reached an FR $\geq 2$ ), yielding a set of 498 genes that were regulated by one or both compounds (online provided as Supplementary Data at http://www.sciencedirect.com; doi:10.1016/j.taap.2007.08.026). In order to compare gene expression levels for all 
compounds tested, the expression data of these genes were clustered for TBTO, APAP, and the three time-matched control groups and also for CsA and B[a]P (Figure 2). Subsets of genes up- or down-regulated by TBTO or APAP can be discriminated, as well as clusters of genes of which the expression levels are increased or reduced after exposure to all compounds. The genes emerging in the latter cluster are listed in Table 3.

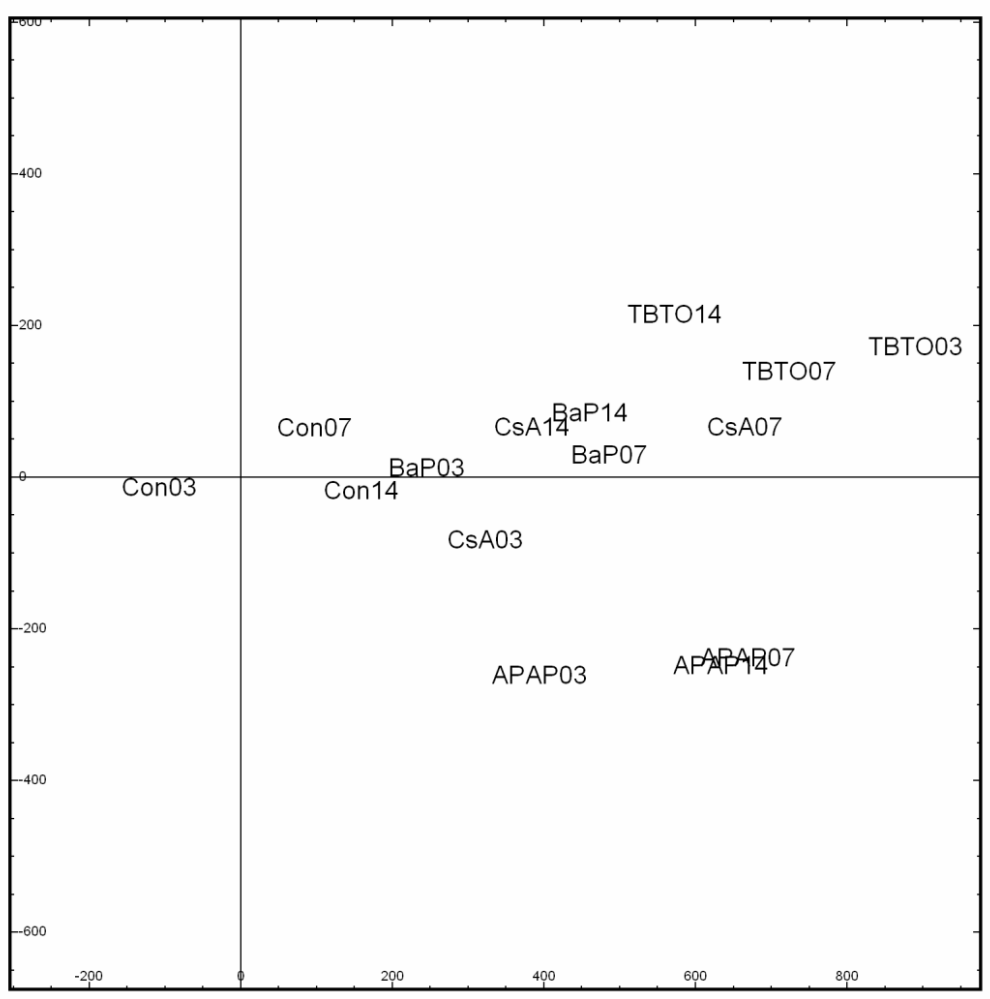

\section{Figure 1.}

Figure 1. PCA plot of the gene expression data acquired for groups of mice exposed to the different test compounds. The data points represent the normalized data (gene expression levels compared to average control levels) obtained by analyzing spleens of mice exposed to TBTO, CsA, B[a]P, or APAP for $3,7,14$, or 28 days using microarrays comprising $11 \mathrm{~K}$ oligos representing 8054 unique genes with immunological or toxicological relevance spotted in duplicate. 


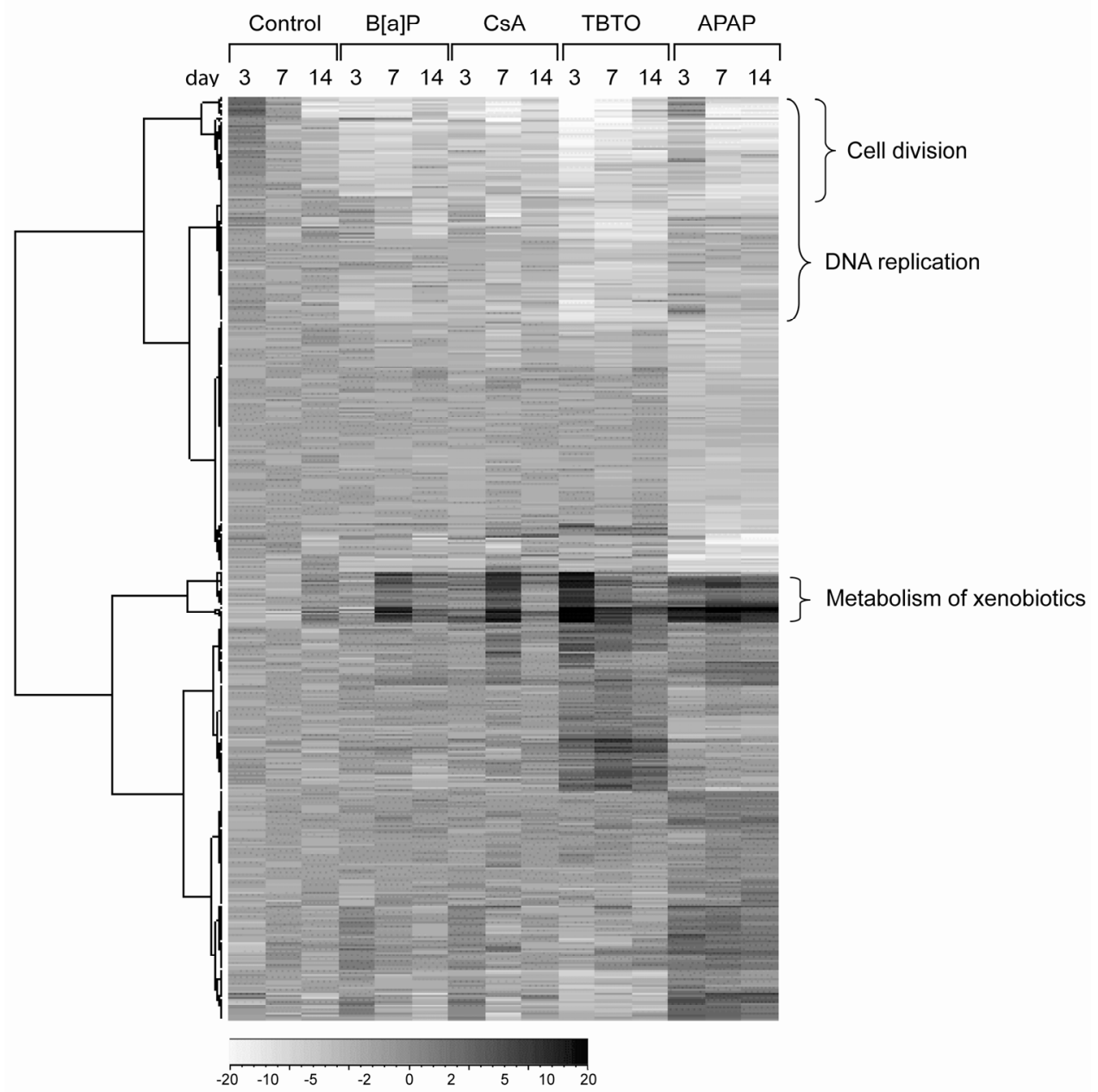

\section{Figure 2.}

Clustering of genes differentially regulated by TBTO, APAP, or both in murine spleens. C57BI/6 mice were exposed to TBTO, CsA, B[a]P, or APAP during 3,7 , or 14 days $(n=8)$. Per exposure group or time-matched control group, 4 pools of 2 RNA samples were analyzed using microarrays comprising $11 \mathrm{~K}$ oligos representing 8054 unique genes with immunological or toxicological relevance spotted in duplicate. TBTO and APAP exposure resulted in differential expression of a total of 498 genes (FDR $<0.1$ ), which are also displayed for the $\mathrm{CsA}$ and $\mathrm{B}[\mathrm{a}] \mathrm{P}$ groups. Expression levels of these genes after $\mathrm{CsA}$ or $\mathrm{B}[\mathrm{a}] \mathrm{P}$ exposure are displayed as well. Expression changes compared to the average control levels are indicated by the bar and corresponding FR: white represents down-regulation and black upregulation. Enrichment for Gene Ontology terms (FDR $<0.1$ ) is indicated next to the corresponding gene clusters. 


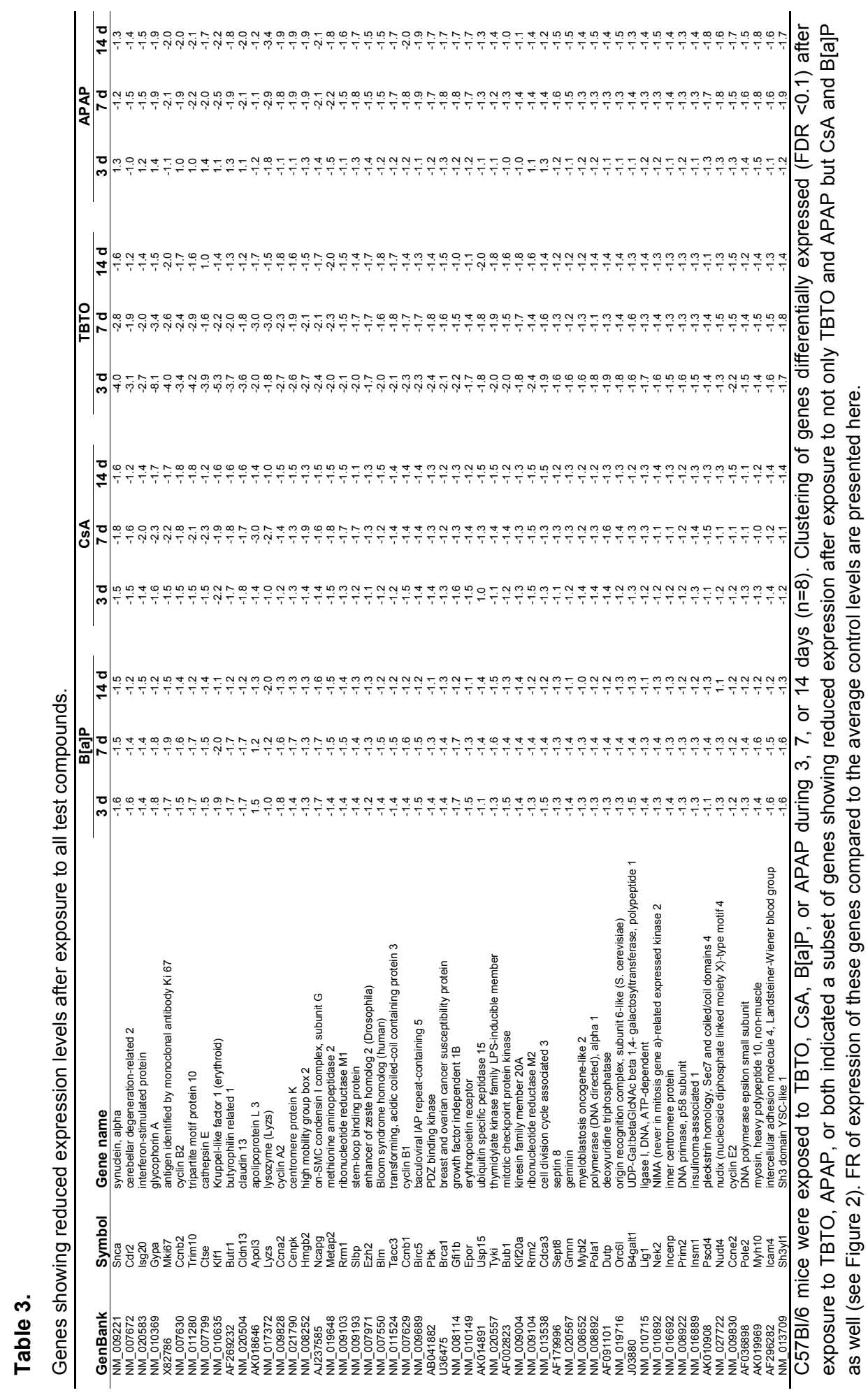




\section{Pathway regulation in subsets of regulated genes}

Significant enrichment of GO terms and regulation of cellular pathways were examined for different subsets of differentially expressed genes. Most MetaCore pathways involving a relatively large part of the different subsets of genes were associated with the cell cycle and these are shown in Table 4.

Marked enrichment for genes associated with cell division and related processes was seen in the set of genes differentially expressed after TBTO exposure, the downregulated subset of these genes, and the part of the latter expressed with an FR $\geq 2$. The GO term DNA replication was over-represented in the subset of genes predominantly down-regulated by TBTO as revealed by clustering of the 498 genes differentially expressed by TBTO, APAP, or both (Figure 2) as well. MetaCore analysis also showed involvement of many genes down-regulated by TBTO in several cell cycle-related pathways (Table 4). Regulation of DNA replication was most affected (Figure 3). The subset of genes differentially up-regulated by TBTO was not significantly enriched for any GO term. Apoptosis-related genes found to be regulated by TBTO were Birc5, Bid, and cytochrome c (down-regulated) and three tumor necrosis factor receptors (Tnfrsf1a, Tnfr3, and $\mathrm{Ngfb}$; up-regulated).

Genes differentially regulated by APAP and the up- and down-regulated subsets of those did not show any significant GO term enrichment. MetaCore analysis showed that some genes regulated by APAP were involved in the cell cycle (Table 4). The downregulated genes Birc3 and Birc5 were involved in apoptotic pathways.

The genes that were commonly (down-)regulated by both TBTO and APAP were, again, enriched for the GO terms related to the mitotic phase of the cell cycle and involved in several MetaCore cell cycle pathways (Table 4 ). Interference with the $G_{2} / M$ and $G_{1} / S$ checkpoints and with DNA replication appeared to be associated with common downregulation of Brca1 and cyclin $\mathrm{A} 2$ at all time points. The metaphase checkpoint was affected by down-regulation of Incenp and Birc5 by both compounds, and chromosome condensation by down-regulation of cyclin A2 and Incenp.

The total set of 498 genes differentially regulated by TBTO, APAP, or both was also enriched for the cell division-related processes mentioned before. Clustering of these genes (Figure 2) discriminated subsets that were predominantly down-regulated by TBTO or APAP, and moreover a cluster of genes of which the expression was decreased after exposure to both compounds and to CsA and B[a]P as well (presented in Table 2). In these clusters cell division was also over-represented, and genes in the latter subset of commonly down-regulated genes were mainly involved in the DNA replication pathway shown in Figure 3. Other pathways which included a relatively large part of the genes commonly down-regulated by all test compounds were also cell cycle-related and are shown in Table 4. Clustering also yielded a subset of genes most strongly up-regulated by both TBTO and APAP and showing increased expression after CsA and B[a]P exposure as well (Figure 2). This cluster was enriched for processes related to metabolism of xenobiotics (monooxygenase, oxidoreductase, and glutathione transferase activity). 
Table 4.

Cell cycle pathways most affected by the test compounds.

\begin{tabular}{|c|c|c|}
\hline Subset of regulated genes & Pathway & Genes \\
\hline \multirow[t]{8}{*}{ Differentially regulated by TBTO } & Regulation of DNA replication & Ccna2, Brca1, Lig1, Pola1, Mcm2, Fen1 \\
\hline & Nucleotide metabolism & $\begin{array}{l}\text { Rrm1, Rrm2, Pola1, Polb, Prim1, Prim2, } \\
\text { Dut }\end{array}$ \\
\hline & $\mathrm{G}_{2} / \mathrm{M}$ checkpoint & Ccna2, Ccnb2, Brca1, Chek1, Cdc25c, \\
\hline & & \\
\hline & Anaphase-promoting complex & $\begin{array}{l}\text { Ccna2, Ccnb2, Bub1, Bub1b, Cct6a, } \\
\text { Cdca3, Cks1b }\end{array}$ \\
\hline & $\begin{array}{l}\text { Start of DNA replication in early } \\
\mathrm{S} \text { phase }\end{array}$ & Orc6l, Mcm2, Pola1 \\
\hline & Chromosome condensation & Ccna2, Ccnb2, Incenp, Smc2 \\
\hline & Metaphase checkpoint & Birc5, Incenp, Bub1, Bub1b \\
\hline \multirow[t]{7}{*}{ Overlap TBTO spleen and thymus } & Regulation of DNA replication & Ccna2, Brca1, Lig1, Pola1, Mcm2 \\
\hline & Anaphase-promoting complex & $\begin{array}{l}\text { Ccna2, Ccnb2, Bub1, Bub1b, Cct6a, } \\
\text { Cdca3, Cks1b }\end{array}$ \\
\hline & Nucleotide metabolism & Rrm1, Rrm2, Pola1 \\
\hline & $\mathrm{G}_{2} / \mathrm{M}$ checkpoint & Ccna2, Ccnb2, Brca1, Chek1, BIm \\
\hline & $\begin{array}{l}\text { Start of DNA replication in early } \\
\mathrm{S} \text { phase }\end{array}$ & Orc6l, Mcm2, Pola1 \\
\hline & $\mathrm{G}_{1} / \mathrm{S}$ checkpoint & Ccna2, Brca1, Chek1, BIm \\
\hline & Chromosome condensation & Ccna2, Ccnb2, Incenp \\
\hline \multirow[t]{2}{*}{ Differentially regulated by APAP } & Metaphase checkpoint & Birc5, Incenp, Cbx5, Zw10 \\
\hline & $\mathrm{G}_{1} / \mathrm{S}$ and $\mathrm{G}_{2} / \mathrm{M}$ checkpoint & Ccna2, Brca1, Cdkn1a (p21)*, Ccnd2* \\
\hline \multirow[t]{4}{*}{ Overlap TBTO and APAP } & $\mathrm{G}_{1} / \mathrm{S}$ and $\mathrm{G}_{2} / \mathrm{M}$ checkpoint & Ccna2, Brca1 \\
\hline & Chromosome condensation & Ccna2, Incenp \\
\hline & Regulation of DNA replication & Ccna2, Brca1 \\
\hline & Metaphase checkpoint & Birc5, Incenp \\
\hline \multirow{7}{*}{$\begin{array}{l}\text { Expression reduced by all } \\
\text { compounds }\end{array}$} & Regulation of DNA replication & Ccna2, Brca1, Lig1, Pola1, Pole2 \\
\hline & Nucleotide metabolism & Rrm1, Rrm2, Pola1, Pole2, Dut \\
\hline & Anaphase-promoting complex & Ccna2, Ccnb2, Bub1, Gmnn, Cdca3 \\
\hline & $\mathrm{G}_{1} / \mathrm{S}$ and $\mathrm{G}_{2} / \mathrm{M}$ checkpoint & Ccna2, Ccnb2, Brca1, Blm \\
\hline & $\begin{array}{l}\text { Start of DNA replication in early } \\
\quad S \text { phase }\end{array}$ & Pola2, Gmnn, Orc6I \\
\hline & Chromosome condensation & Ccna2, Ccnb2, Incenp \\
\hline & Metaphase checkpoint & Birc5, Incenp, Bub1 \\
\hline
\end{tabular}

Involvement of genes differentially regulated in murine spleens after exposure to TBTO, CsA, B[a]P, or APAP as measured by microarray analysis (FDR $<0.1)$ in cellular pathways was identified and visualized using MetaCore by GeneGo Inc. A relatively large part of the genes differentially regulated by TBTO, APAP, or both and of the cluster of genes differentially regulated by TBTO and/or APAP and showing a trend towards down-regulation by CsA and $\mathrm{B}[\mathrm{a}] \mathrm{P}$ were involved in cell cycle-related pathways, and so were the genes regulated by TBTO in the spleen as well as in the thymus as detected in a previous study [22]. All genes involved were down-regulated at each time point, except for the genes marked by "*, which were up-regulated. 


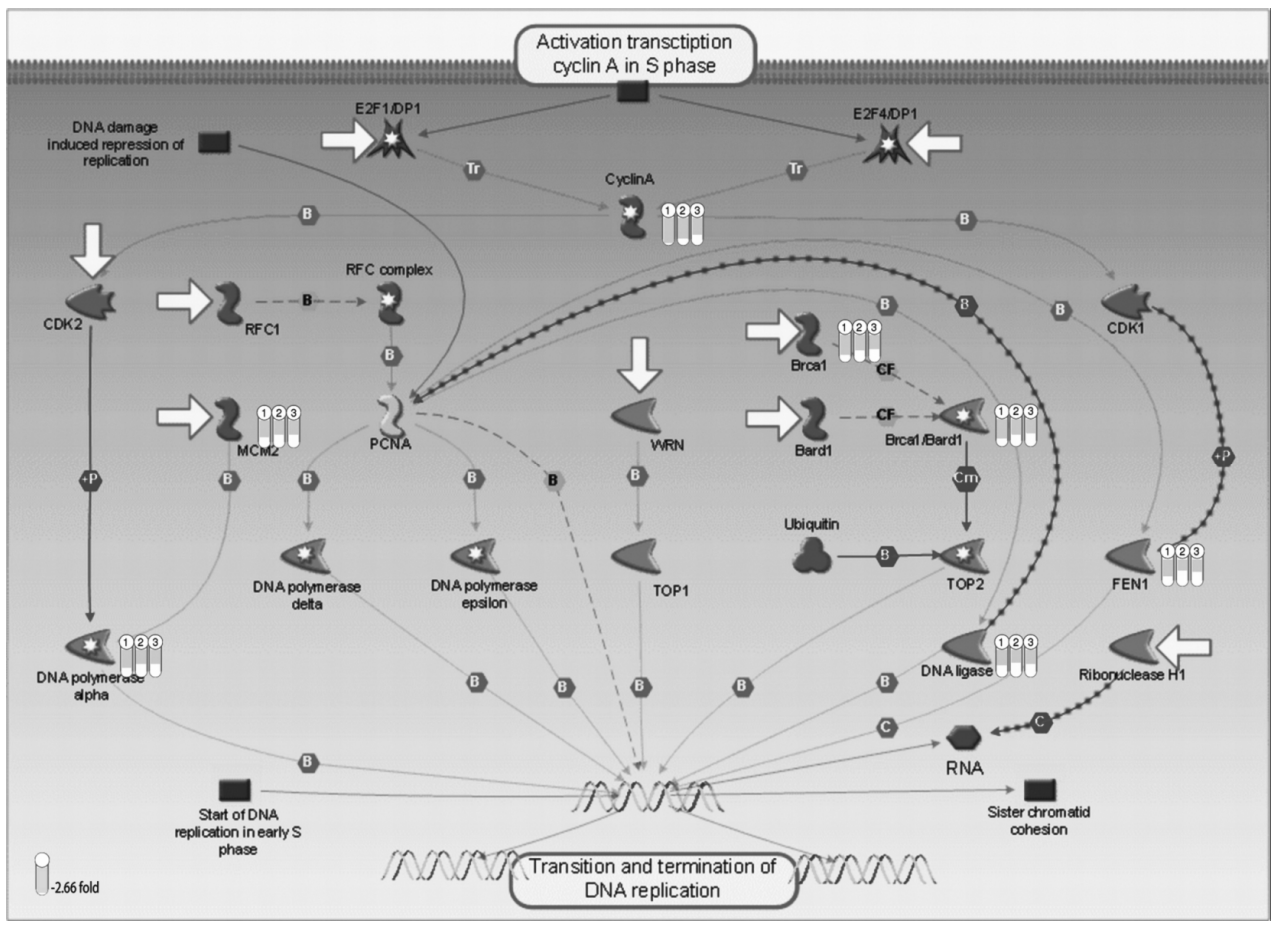

Figure 3.

Regulation of DNA replication by TBTO. C57BI/6 mice were exposed to TBTO during 3, 7, or 14 days $(n=8)$, respectively indicated by 1,2 , and 3 in the figure. Involvement of genes differentially regulated in the spleen (FDR $<0.1$ ), as identified by microarray analysis, in cellular pathways was identified and visualized using MetaCore by GeneGo Inc. The bars represent the degree of down-regulation of the genes involved at the different time points. Arrows comprising a sign referring to the mechanism involved indicate a positive effect of the protein products, most often by binding ('B') to another protein, and dotted arrows represent a negative effect (for legend see http://www.genego.com/files/MC_legend.pdf). 


\section{Modulation of immune function by APAP}

An adapted LLNA was performed to investigate immunomodulatory effects of APAP at dose levels of 500 and 5000 ppm. The effects of both APAP doses on DNCB-induced lymphocyte proliferation in draining LN are shown in Figure 4. The exposure resulted in a reduction of the $\left[{ }^{3} \mathrm{H}\right]$-thymidine incorporation compared to the control group and was comparable for both dose levels at all DNCB concentrations except for that of $0.66 \%$. There, the dose of $500 \mathrm{ppm}$ caused a more severe reduction of $\left[{ }^{3} \mathrm{H}\right]$-thymidine activity, which differed significantly from the control group $(p=0.027)$.

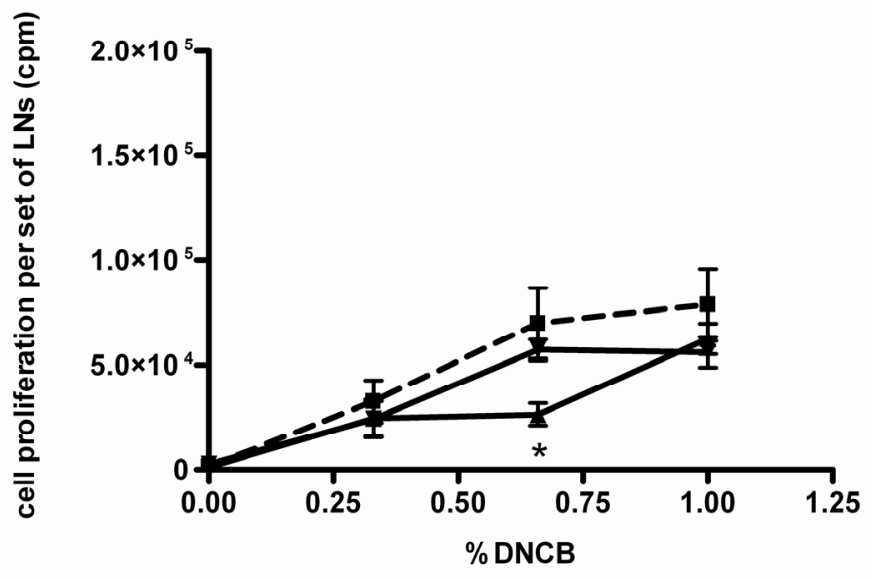

Figure 4.

Modulation of immune function by APAP. C57BL/6 mice were exposed to $500(\mathbf{\Lambda})$ or $5000(\boldsymbol{\nabla}) \mathrm{ppm}$ APAP during 4 weeks. These mice as well as the unexposed animals ( $\mathbf{-})$ were subdivided in groups $(n=4,2$ females and 2 males) that were topically treated with DNCB at different concentrations $(0 \%$, $0.33 \%, 0.66 \%$ and $1 \%)$. $\left[{ }^{3} \mathrm{H}\right]$-thymidine incorporation was measured to determine the proliferative capacity of auricular lymph node (LN) cells and is expressed per set of auricular LN as the mean of the measured counts per minute (cpm) per group times the mean total $L N$ cell number per group \pm SEM. Significant differences from the control group are indicated by * $(p<0.05)$. 


\section{Discussion}

Since gene expression profiles shared by immunosuppressive agents can be of use for development of screening assays for identification of adverse effects on immune function, we performed microarray analysis in murine spleens to investigate transcriptional effects of a range of model immunotoxicants. In addition, gene expression profiles induced by APAP were examined in order to gain insight into its immunomodulating potential as some evidence on immunosuppressive effects of APAP was present [25-29]. A Gene Ontology term analysis taking all gene expression levels measured after 7 days of exposure into account group wise showed compound-specific as well as overlapping effects. One of the processes specifically affected by TBTO was disruption of cellular respiration and this effect has been reported previously $[3,36,37]$. Transmembrane signaling was up-regulated and may be involved in transmission of signals mediating TBTO's cellular effects. CsA caused, among other things, a significant regulation of organ morphogenesis, which can be explained by its binding to calcineurin, since the calcineurin/NFAT pathway is known to be involved in morphogenetic processes [38-43]. One of the effects of $B$ [a]P exposure was inhibition of the cellular response to DNA damage. While modulation of this response was to be expected in view of the genotoxic effects of B[a]P metabolites, an enhancement might have been more plausible. However, the processes of DNA replication and repair partly overlap, and the expression levels of the genes involved in both processes may thus be reduced due to inhibition of cell division (see below). Repression of DNA repair genes by a reactive $\mathrm{B}[\mathrm{a}] \mathrm{P}$ metabolite has been detected by microarray analysis before and was argued to enable genotoxic effects [44].

An important finding was the inhibition of several immunological processes by both CsA and B[a]P, which will contribute to their immunotoxic effects. Inhibition of $\mathrm{T}$ cell activation by CsA and $B[a] P$ was detected previously by transcriptional profiling [45-47]. Modulation of extracellular matrix genes, which was detected for TBTO, CsA, and B[a]P, has also been found to be a transcriptional effect of $B[a] P$ previously and was ascribed to oxidative stress generated by exposure to this compound [45]. This response, as well as processes related to differentiation, may be involved in tissue regeneration. All three immunotoxicants also induced xenobiotic metabolism. Induction of oxidoreductase activity is a regular cellular response to exposure to xenobiotics, and is in agreement with effects observed for B[a]P by microarray analysis in a human lymphoblastoid cell line $[44,48]$.

The process most significantly affected by TBTO, B[a]P, and APAP and being one of the most regulated processes for CsA was cell division. We recently showed by gene expression profiling that inhibition of cell proliferation was also the most pronounced effect of TBTO in the thymus of the mice [22], and this effect of TBTO has been reported by others as well $[4,10,13]$. Inhibition of cell division by CsA has been reported previously for many cell types, among which were primary splenocytes [13,49-54]. Growth arrest in the $G_{0} / G_{1}$ phase of the cell cycle $[53,55-60]$ or at the $G_{1} / S$ or $G_{2} / M$ checkpoints $[61,62]$ and inhibition of DNA synthesis [63-65] by CsA were frequently observed. Similarly, reduction of proliferation after $\mathrm{B}[\mathrm{a}] \mathrm{P}$ exposure has been detected in several cell lines (in this case frequently by $\mathrm{G}_{2} / \mathrm{M}$ or $\mathrm{S}$ phase arrest), also by gene expression profiling [66-79]. Inhibition of DNA synthesis and cell proliferation by low and high concentrations of APAP have been demonstrated previously as well, among others in human lymphocytes [29,80,81], and APAP up-regulated genes involved in growth arrest in microarray studies in murine livers 
$[82,83]$. Cell types with a high proliferation rate, such as lymphocytes, will be particularly sensitive to the anti-proliferative effects of these compounds.

Analysis of differential expression of individual genes provided additional insight into regulation of biological processes. Genes regulated by TBTO were mainly involved in mitosis and DNA replication. Of the genes differentially regulated by TBTO in the thymus [22], 68 genes were regulated in the spleen in the present study as well and 16 of those were also regulated by APAP in the spleen. When less strict criteria (FDR $<0.1$ and FR $\geq 1.5$ ) are applied to select differentially expressed genes in the thymus, 1685 genes are found of which 117 genes were also differentially expressed in the spleen after TBTO exposure and 20 of those after APAP exposure as well. These 117 overlapping genes (online provided as Supplementary Data at http://www.sciencedirect.com; doi: 10.1016/j.taap.2007.08.026) are also enriched for cell cycle-related processes such as DNA replication (Figure 3 and Table 4), thus supporting previous findings and providing clues to the mechanism of inhibition of cell proliferation by TBTO. The total set of genes commonly regulated by TBTO and APAP in the spleen was again enriched for cell cyclerelated processes. The genes involved in cell division were most down-regulated by APAP at day 7 and 14, which correlates with the reduction of body weight gain detected at these time points but not after 3 days of exposure. These genes showed reduced expression after $\mathrm{CsA}$ and $\mathrm{B}[\mathrm{a}] \mathrm{P}$ exposure as well, although $\mathrm{CsA}$ and $\mathrm{B}[\mathrm{a}] \mathrm{P}$ did not cause statistically significant changes in expression of individual genes as compared to the control group.

Other observations also indicated less pronounced effects of CsA and B[a]P: histological irregularities were noticed in the spleen after TBTO exposure but not after CsA and $\mathrm{B}[\mathrm{a}] \mathrm{P}$ exposure, and growth reduction was most severe in the TBTO-exposed mice. This group also had the highest incidence of macroscopically observed irregularities, all being decreased organ size. Furthermore, genes involved in xenobiotic metabolism were most strongly activated by TBTO already after 3 days of exposure, whereas the expression of these genes was most induced after 7 days of exposure to CsA and B[a]P. Nevertheless, CsA and B[a]P earlier showed a level of suppression of the proliferative response to allergen application in the adapted LLNA comparable to TBTO [21], possibly because the effects of $\mathrm{CsA}$ and $\mathrm{B}[\mathrm{a}] \mathrm{P}$ were more severe after the longer exposure period of 28 days applied in the modified LLNA.

Because of the earlier indications of immunosuppressive effects of APAP and effects on gene expression overlapping with the immunotoxic model compounds in the present study, we tested immunomodulating effects of APAP in an LLNA adapted for evaluating functioning of the immune system as well. A reduced immune response to allergen was also detected after exposure to this compound, both at the dose level used for microarray analysis and at a ten times lower dose level. After administration of latter dose, the highest DNCB concentration caused less suppression of the proliferative response than the intermediate dose. An explanation for this may be that the highest DNCB concentration causes such a vigorous reaction of the lymph node cells, that this can hardly be suppressed by APAP, whereas the reaction to a lower concentration DNCB still can. The fact that the LLNA curve after administration of 5000 ppm APAP does show a dose-response may be explained by the higher dose of APAP (and thus a higher degree of immunosuppression). Surprisingly, the degree of inhibition of immune function by APAP was comparable to effects of the three immunotoxicants [21]. In accordance with our findings, a recent publication reported a hepatotoxic dose of APAP to suppress the 
delayed-type hypersensitivity response to the same allergen in mice and to cause lymphocyte depletion in the spleen and in other organs [84]. It can therefore be concluded that APAP also has immunosuppressive properties at the dose levels used and that cell cycle arrest, at least in cells of the immune system, is a common mechanism of immunosuppression shared by the test compounds. The detection of immunotoxic effects of APAP is supported by the observation that some spleens were reduced in size in the APAP group whereas body weight gain was, in contrast to the other groups, not reduced. APAP-induced immunosuppression might prevent allergic or autoimmune responses to the formation of protein adducts by its reactive metabolite, which would explain the low incidence of these reactions in patients suffering from APAP-induced liver disease [28,84]. Since no histopathological irregularities were observed in the livers of the mice involved in our study (possibly due to administration via food instead of intraperitoneal), immunosuppression after APAP exposure appears not to be dependent on induction of hepatotoxicity.

Although we detected inhibition of cell division-related processes by all test compounds, it is uncertain if the compounds targeted the same phase of the cell cycle. TBTO appeared for example to predominantly inhibit DNA replication, whereas effects of CsA on cell proliferation might be secondary to calcineurin inhibition or TGF- $\beta$ induction $[47,65], B[a] P$ may lead to cell cycle arrest by p53 and Cdkn1a (p21) up-regulation after oxidative or genotoxic stress allowing repair of DNA damage $[70,73,75,78,85]$, and APAP might alter gene transcription by binding of its reactive metabolite to proteins and DNA or through oxidative stress [23]. Furthermore, since transcriptional effects were examined in whole spleens, it is possible that the anti-proliferative effect of the different compounds occurred in different cell types. In addition, it cannot be ruled out that the effects measured in the spleen were indirect and resulted from a depletion of rapidly dividing lymphocytes in the bone marrow or thymus resulting in influx of slowly-dividing cells in the spleen [12]. Although these issues are of mechanistic importance, they do not impede the identification of common effects of immunotoxicants in the spleen, being an eventual transcriptional profile indicating cell cycle arrest.

Several genes showed decreased expression levels after exposure to each compound and were involved in several cell division-related processes. Monitoring of changes in transcription of cell cycle genes such as Ccna2 and Brca1 (known to be involved in cell cycle regulation, and the latter is also a tumor suppressor gene, mutations in which are associated with breast cancer) and Birc5 and Incenp (both known to regulate mitosis) may therefore be suitable for identification of immunosuppressive compounds. $\mathrm{B}[\mathrm{a}] \mathrm{P}$ has also been shown to inhibit Brca1 expression [86], and $\mathrm{B}[\mathrm{a}] \mathrm{P}$-induced cell cycle arrest has been reported to be mediated by reduced cyclin $A$ and $B$ expression $[48,74,87]$. Moreover, Zhu et al. showed down-regulation of Bub1, Bub1b, and MCM2 by B[a]P and these genes were also significantly down-regulated by TBTO in the present study. In addition, Cdkn1 was significantly up-regulated by APAP in the present experiment and in a study performed by others [82] and has previously been reported to be involved in effects of CsA $[47,60]$ and $B[a] P$ (see references above) as well.

Several microarray studies on anti-proliferative and cancer-inhibiting compounds such as methotrexate, lithium, cantharidin, cerivastatin, and flavone have also shown regulation of genes involved in DNA replication and cell division, e.g. cyclin A, cyclin D1, cyclin E, cdc25C, cdc6, and p21 [88-92]. This confirms the induction of anti-proliferative 
effects of the compounds examined in the present study. In addition, known antiproliferative agents are often immunotoxic as well, further underscoring the relevance of suppression of proliferation of lymphocytes for immunotoxicity. Obviously, a larger number of immunotoxicants should be examined in order to ascertain if the expression of these genes, expression of other genes that showed a trend towards common regulation, and cell cycle arrest in general are truly predictive and universal for immunotoxic effects of xenobiotics. Immunotoxicants can have different mechanisms of action, and compounds affecting macrophage or natural killer cell function may for example not be identified as immunotoxic by measuring effects on cell proliferation. Besides, it should be noted that it cannot be ruled out for any of the effects observed in our study that these are partly mediated by general toxicity because of the high dose levels used, and effects of lower doses should thus be studied in future experiments as well.

Altogether, several conclusions can be drawn from our study. Firstly, group wise analysis of effects on GO terms in total gene expression profiles proved a useful tool for identification of regulation of processes at the transcriptional level that would not have been detected by taking into account differentially expressed genes alone. Subtle but coordinate up- or down-regulation of many genes within a specific functional category indicated several effects that are relevant for the mechanism of action of the different compounds. Secondly, even though the thymus is often studied in the area of immunotoxicology since this organ is sensitive to effects of immunotoxicants and thereby often a target organ [93], analysis of transcriptional effects in the spleen appeared to be able to demonstrate immunotoxic effects of the different compounds. Finally, all compounds showed a certain degree of inhibition of cell proliferation. Although the different compounds may act by different mechanisms of action, several commonly regulated genes were identified and cell cycle arrest appeared to be a cause of impairment of immune function by the three model immunotoxicants and by APAP as well. Measurement of lymphocyte proliferation after xenobiotic exposure, as is part of current methods for evaluation of immunotoxicity such as measurement of proliferative responses to mitogen or allergen, thus remains a suitable tool to detect immunosuppression. Although additional studies are needed to examine the specificity and predictive power for immunotoxic events of the commonly regulated processes and genes identified, and functional and clinical implications of the transcriptional changes induced by APAP should be further elucidated, our results provide valuable information on immunomodulating properties of APAP and for evaluation of immunotoxicity in general.

\section{Acknowledgements}

We thank Femke van den Berg, Rebecca Esveldt - van Lange, and Tessa van der Hoeven for their excellent assistance, Cor Schot and co-workers for the housing of the mice, Coen Moolenbeek for the biotechnical support, and Dolf Beems and Wim de Jong for the histological evaluations. This research was supported by a grant of CEFIC. 


\section{References}

1. Baken, K.A., Vandebriel, R.J., Pennings, J.L.A., Kleinjans, J.C., Van Loveren, H. (2007) Toxicogenomics in the assessment of immunotoxicity. Methods 41, 132-141.

2. Luebke, R.W., Holsapple, M.P., Ladics, G.S., Luster, M.I., Selgrade, M., Smialowicz, R.J., Woolhiser, M.R., Germolec, D.R. (2006) Immunotoxicogenomics: the potential of genomics technology in the immunotoxicity risk assessment process. Toxicol Sci 94, 22-27.

3. Boyer, I.J. (1989) Toxicity of dibutyltin, tributyltin and other organotin compounds to humans and to experimental animals. Toxicology 55, 253-298.

4. Vos, J.G., De Klerk, A., Krajnc, E.I., Kruizinga, W., Van Ommen, B., Rozing, J. (1984) Toxicity of bis(tri-nbutyltin)oxide in the rat. II. Suppression of thymus-dependent immune responses and of parameters of nonspecific resistance after short-term exposure. Toxicol Appl Pharmacol 75, 387-408.

5. Snoeij, N.J., Penninks, A.H., Seinen, W. (1987) Biological activity of organotin compounds--an overview. Environ Res 44, 335-353.

6. Verdier, F., Virat, M., Schweinfurth, H., Descotes, J. (1991) Immunotoxicity of bis(tri-n-butyltin) oxide in the rat. J Toxicol Environ Health 32, 307-317.

7. Aw, T.Y., Nicotera, P., Manzo, L., Orrenius, S. (1990) Tributyltin stimulates apoptosis in rat thymocytes. Arch Biochem Biophys 283, 46-50.

8. Gennari, A., Potters, M., Seinen, W., Pieters, R. (1997) Organotin-induced apoptosis as observed in vitro is not relevant for induction of thymus atrophy at antiproliferative doses. Toxicol Appl Pharmacol 147, 259-266.

9. Grundler, W., Dirscherl, P., Beisker, W., Marx, K., Stampfl, A., Maier, K., Zimmermann, I., Nusse, M. (2001) Early functional apoptotic responses of thymocytes induced by Tri-n-butyltin. Cytometry 44, 45-56.

10. Nakata, H., Sakakibara, A., Kanoh, M., Kudo, S., Watanabe, H., Nagai, N., Miyazaki, N., Asano, Y., Tanabe, S. (2002) Evaluation of mitogen-induced responses in marine mammal and human lymphocytes by in-vitro exposure of butyltins and non-ortho coplanar PCBs. Environ Pollut 120, 245-253.

11. Raffray, M., McCarthy, D., Snowden, R.T., Cohen, G.M. (1993) Apoptosis as a mechanism of tributyltin cytotoxicity to thymocytes: relationship of apoptotic markers to biochemical and cellular effects. Toxicol Appl Pharmacol 119, 122-130.

12. Snoeij, N.J., Penninks, A.H., Seinen, W. (1988) Dibutyltin and tributyltin compounds induce thymus atrophy in rats due to a selective action on thymic lymphoblasts. Int J Immunopharmacol 10, 891-899.

13. Vandebriel, R.J., Spiekstra, S.W., Hudspith, B.N., Meredith, C., Van Loveren, H. (1999) In vitro exposure effects of cyclosporin A and bis(tri-n-butyltin)oxide on lymphocyte proliferation, cytokine (receptor) mRNA expression, and cell surface marker expression in rat thymocytes and splenocytes. Toxicology 135, 49-66.

14. Hamawy, M.M. (2003) Molecular actions of calcineurin inhibitors. Drug News Perspect 16, 277-282.

15. Kiani, A., Rao, A., Aramburu, J. (2000) Manipulating immune responses with immunosuppressive agents that target NFAT. Immunity 12, 359-372.

16. De Waal, E.J., Timmerman, H.H., Dortant, P.M., Kranjc, M.A., Van Loveren, H. (1995) Investigation of a screening battery for immunotoxicity of pharmaceuticals within a 28-day oral toxicity study using azathioprine and cyclosporin A as model compounds. Regul Toxicol Pharmacol 21, 327-338.

17. Lebrec, H., Roger, R., Blot, C., Burleson, G.R., Bohuon, C., Pallardy, M. (1995) Immunotoxicological investigation using pharmaceutical drugs. In vitro evaluation of immune effects using rodent or human immune cells. Toxicology 96, 147-156.

18. Richter-Reichhelm, H.B., Schulte, A.E. (1998) Results of a cyclosporin A ringstudy. Toxicology 129, 91-94.

19. De Jong, W.H., Kroese, E.D., Vos, J.G., Van Loveren, H. (1999) Detection of immunotoxicity of benzo[a]pyrene in a subacute toxicity study after oral exposure in rats. Toxicol Sci 50, 214-220.

20. White, K.L., Kawabata, T.T., Ladics, G.S. (1994) Mechanisms of polycyclic aromatic hydrocarbon immunotoxicity. In: Immunotoxicology and Immunopharmacology (Dean JH, Luster MI, Munson AE, Kimber I Eds) 123-142. Raven Press Ltd, New York, USA.

21. Van den Berg, F.A., Baken, K.A., Vermeulen, J.P., Gremmer, E.R., Van Steeg, H., Van Loveren, H. (2005) Use of the local lymph node assay in assessment of immune function. Toxicology 211, 107-114.

22. Baken, K.A., Pennings, J.L.A., De Vries, A., Breit, T.M., Van Steeg, H., Van Loveren, H. (2006) Gene expression profiling of bis(tri-n-butyltin)oxide (TBTO) induced immunotoxicity in mice and rats. J Immunotoxicol 3, 227-244.

23. Bessems, J.G., Vermeulen, N.P. (2001) Paracetamol (acetaminophen)-induced toxicity: molecular and biochemical mechanisms, analogues and protective approaches. Crit Rev Toxicol 31, 55-138.

24. Kaplowitz, N. (2004) Acetaminophen hepatoxicity: what do we know, what don't we know, and what do we do next? Hepatology 40, 23-26. 
25. Doran, T.F., De Angelis, C., Baumgardner, R.A., Mellits, E.D. (1989) Acetaminophen: more harm than good for chickenpox? J Pediatr 114, 1045-1048.

26. Fyfe, A.I., Wright, J.M. (1990) Chronic acetaminophen ingestion associated with $(1 ; 7)(\mathrm{p} 11 ; \mathrm{p} 11)$ translocation and immune deficiency syndrome. Am J Med 88, 443-444.

27. Graham, N.M., Burrell, C.J., Douglas, R.M., Debelle, P., Davies, L. (1990) Adverse effects of aspirin, acetaminophen, and ibuprofen on immune function, viral shedding, and clinical status in rhinovirus-infected volunteers. J Infect Dis 162, 1277-1282.

28. Ueno, K., Yamaura, K., Nakamura, T., Satoh, T., Yano, S. (2000) Acetaminophen-induced immunosuppression associated with hepatotoxicity in mice. Res Commun Mol Pathol Pharmacol 108, 237251.

29. Yamaura, K., Ogawa, K., Yonekawa, T., Nakamura, T., Yano, S., Ueno, K. (2002) Inhibition of the antibody production by acetaminophen independent of liver injury in mice. Biol Pharm Bull 25, 201-205.

30. Beissbarth, T., Speed, T.P. (2004) GOstat: find statistically overrepresented Gene Ontologies within a group of genes. Bioinformatics 20, 1464-1465.

31. Kerr, M.K., Martin, M., Churchill, G.A. (2000) Analysis of variance for gene expression microarray data. J Comput Biol 7, 819-837.

32. Wolfinger, R.D., Gibson, G., Wolfinger, E.D., Bennett, L., Hamadeh, H., Bushel, P., Afshari, C., Paules, R.S. (2001) Assessing gene significance from cDNA microarray expression data via mixed models. J Comput Biol 8, 625-637.

33. Cui, X., Churchill, G.A. (2003) Statistical tests for differential expression in cDNA microarray experiments. Genome Biol 4, 210-

34. Benjamini, Y., Hochberg, Y. (1995) Controlling the false discovery rate: a practical and powerful approach to multiple testing. J Roy Stat Soc B 57, 289-300.

35. Woolhiser, M.R., Munson, A.E., Meade, B.J. (2000) Comparison of mouse strains using the local lymph node assay. Toxicology 146, 221-227.

36. Snoeij, N.J., Punt, P.M., Penninks, A.H., Seinen, W. (1986) Effects of tri-n-butyltin chloride on energy metabolism, macromolecular synthesis, precursor uptake and cyclic AMP production in isolated rat thymocytes. Biochim Biophys Acta 852, 234-243.

37. von Ballmoos, C., Brunner, J., Dimroth, P. (2004) The ion channel of F-ATP synthase is the target of toxic organotin compounds. Proc Natl Acad Sci U S A 101, 11239-11244.

38. Chang, C.P., Neilson, J.R., Bayle, J.H., Gestwicki, J.E., Kuo, A., Stankunas, K., Graef, I.A., Crabtree, G.R. (2004) A field of myocardial-endocardial NFAT signaling underlies heart valve morphogenesis. Cell 118, 649663.

39. Dave, V., Childs, T., Xu, Y., Ikegami, M., Besnard, V., Maeda, Y., Wert, S.E., Neilson, J.R., Crabtree, G.R., Whitsett, J.A. (2006) Calcineurin/Nfat signaling is required for perinatal lung maturation and function. J Clin Invest 116, 2597-2609.

40. Graef, I.A., Chen, F., Crabtree, G.R. (2001) NFAT signaling in vertebrate development. Curr Opin Genet Dev 11, 505-512.

41. Graef, I.A., Wang, F., Charron, F., Chen, L., Neilson, J., Tessier-Lavigne, M., Crabtree, G.R. (2003) Neurotrophins and netrins require calcineurin/NFAT signaling to stimulate outgrowth of embryonic axons. Cell 113, 657-670.

42. Heit, J.J., Apelqvist, A.A., Gu, X., Winslow, M.M., Neilson, J.R., Crabtree, G.R., Kim, S.K. (2006) Calcineurin/NFAT signalling regulates pancreatic beta-cell growth and function. Nature 443, 345-349.

43. Winslow, M.M., Pan, M., Starbuck, M., Gallo, E.M., Deng, L., Karsenty, G., Crabtree, G.R. (2006) Calcineurin/NFAT signaling in osteoblasts regulates bone mass. Dev Cell 10, 771-782.

44. Luo, W., Fan, W., Xie, H., Jing, L., Ricicki, E., Vouros, P., Zhao, L.P., Zarbl, H. (2005) Phenotypic anchoring of global gene expression profiles induced by $\mathrm{N}$-hydroxy-4-acetylaminobiphenyl and benzo[a]pyrene diol epoxide reveals correlations between expression profiles and mechanism of toxicity. Chem Res Toxicol 18, 619-629.

45. Johnson, C.D., Balagurunathan, Y., Lu, K.P., Tadesse, M., Falahatpisheh, M.H., Carroll, R.J., Dougherty, E.R., Afshari, C.A., Ramos, K.S. (2003) Genomic profiles and predictive biological networks in oxidantinduced atherogenesis. Physiol Genomics 13, 263-275.

46. Cristillo, A.D., Bierer, B.E. (2002) Identification of novel targets of immunosuppressive agents by cDNAbased microarray analysis. J Biol Chem 277, 4465-4476.

47. Mascarell, L., Truffa-Bachi, P. (2003) New aspects of cyclosporin a mode of action: from gene silencing to gene up-regulation. Mini Rev Med Chem 3, 205-214.

48. Akerman, G.S., Rosenzweig, B.A., Domon, O.E., McGarrity, L.J., Blankenship, L.R., Tsai, C.A., Culp, S.J., Macgregor, J.T., Sistare, F.D., Chen, J.J., Morris, S.M. (2004) Gene expression profiles and genetic damage in benzo(a)pyrene diol epoxide-exposed TK6 cells. Mutat Res 549, 43-64. 
49. Furue, M., Gaspari, A.A., Katz, S.I. (1988) The effect of cyclosporin A on epidermal cells. II. Cyclosporin A inhibits proliferation of normal and transformed keratinocytes. J Invest Dermatol 90, 796-800.

50. Schneider, G., Oswald, F., Wahl, C., Greten, F.R., Adler, G., Schmid, R.M. (2002) Cyclosporine inhibits growth through the activating transcription factor/cAMP-responsive element-binding protein binding site in the cyclin D1 promoter. J Biol Chem 277, 43599-43607.

51. Shang, F.J., Zhao, L.Y., Zheng, Q.S., Wang, J.P. (2006) Inhibitory effect of cyclosporin A on growth and collagen synthesis of rat cardiac fibroblasts induced by arginine vasopressin. Yao Xue Xue Bao 41, 10441049.

52. Sharpe, G.R., Fisher, C. (1990) Time-dependent inhibition of growth of human keratinocytes and fibroblasts by cyclosporin A: effect on keratinocytes at therapeutic blood levels. Br J Dermatol 123, 207-213.

53. Yonish-Rouach, E., Kimchi, A., Rubinstein, M. (1991) The antiproliferative effect of cyclosporine on hematopoietic and lymphoblastoid cell lines--common mechanistic elements with interferon-alpha. Transplantation 51, 1276-1282.

54. Zhang, A.B., Zheng, S.S. (2006) Strong additive effect of calcitriol and cyclosporine A on lymphocyte proliferation in vitro and rat liver allotransplantations in vivo. Chin Med J (Engl ) 119, 2090-2095.

55. Gottschalk, A.R., Boise, L.H., Thompson, C.B., Quintans, J. (1994) Identification of immunosuppressantinduced apoptosis in a murine B-cell line and its prevention by bcl-x but not bcl-2. Proc Natl Acad Sci U S A 91, 7350-7354.

56. Jeon, S.H., Piao, Y.J., Choi, K.J., Hong, F., Baek, H.W., Kang, I., Ha, J., Kim, S.S., Chang, S.G. (2005) Prednisolone suppresses cyclosporin A-induced apoptosis but not cell cycle arrest in MDCK cells. Arch Biochem Biophys 435, 382-392.

57. Kahl, C.R., Means, A.R. (2004) Calcineurin regulates cyclin D1 accumulation in growth-stimulated fibroblasts. Mol Biol Cell 15, 1833-1842.

58. Roy, M.K., Takenaka, M., Kobori, M., Nakahara, K., Isobe, S., Tsushida, T. (2006) Apoptosis, necrosis and cell proliferation-inhibition by cyclosporine A in U937 cells (a human monocytic cell line). Pharmacol Res 53, 293-302.

59. Wicker, L.S., Boltz, R.C., Jr., Matt, V., Nichols, E.A., Peterson, L.B., Sigal, N.H. (1990) Suppression of B cell activation by cyclosporin A, FK506 and rapamycin. Eur J Immunol 20, 2277-2283.

60. Zupanska, A., Dziembowska, M., Ellert-Miklaszewska, A., Gaweda-Walerych, K., Kaminska, B. (2005) Cyclosporine a induces growth arrest or programmed cell death of human glioma cells. Neurochem Int 47, 430-441.

61. Lally, C., Healy, E., Ryan, M.P. (1999) Cyclosporine A-induced cell cycle arrest and cell death in renal epithelial cells. Kidney Int 56, 1254-1257.

62. Wolf, G., Thaiss, F., Stahl, R.A. (1995) Cyclosporine stimulates expression of transforming growth factor-beta in renal cells. Possible mechanism of cyclosporines antiproliferative effects. Transplantation 60, 237-241.

63. Richter, A., Davies, D.E., Alexander, P. (1995) Growth inhibitory effects of FK506 and cyclosporin A independent of inhibition of calcineurin. Biochem Pharmacol 49, 367-373.

64. Thyberg, J., Hansson, G.K. (1991) Cyclosporine A inhibits induction of DNA synthesis by PDGF and other peptide mitogens in cultured rat aortic smooth muscle cells and dermal fibroblasts. Growth Factors 4, 209219.

65. Tomono, M., Toyoshima, K., Ito, M., Amano, H. (1996) Calcineurin is essential for DNA synthesis in Swiss 3 T3 fibroblasts. Biochem J 317 ( Pt 3), 675-680.

66. Allan, L.L., Schlezinger, J.J., Shansab, M., Sherr, D.H. (2006) CYP1A1 in polycyclic aromatic hydrocarboninduced B lymphocyte growth suppression. Biochem Biophys Res Commun 342, 227-235.

67. Vandebriel, R.J., Meredith, C., Scott, M.P., Roholl, P.J., Van Loveren, H. (1998) Effects of in vivo exposure to bis(tri-n-butyltin)oxide, hexachlorobenzene, and benzo(a)pyrene on cytokine (receptor) mRNA levels in cultured rat splenocytes and on IL-2 receptor protein levels. Toxicol Appl Pharmacol 148, 126-136.

68. Ginsberg, G.L., Atherholt, T.B., Butler, G.H. (1989) Benzo[a]pyrene-induced immunotoxicity: comparison to DNA adduct formation in vivo, in cultured splenocytes, and in microsomal systems. J Toxicol Environ Health 28, 205-220.

69. Das, U.N. (2002) Effect of anti-oxidants, free radical quenchers and cyclo-oxygenase inhibitor on benzo(a)pyrene-induced suppression of human lymphocyte mitogenesis in vitro. Med Sci Monit 8, BR205BR207.

70. Binkova, B., Giguere, Y., Rossner, P., Jr., Dostal, M., Sram, R.J. (2000) The effect of dibenzo[a,1]pyrene and benzo[a]pyrene on human diploid lung fibroblasts: the induction of DNA adducts, expression of p53 and p21(WAF1) proteins and cell cycle distribution. Mutat Res 471, 57-70.

71. Caino, M.C., Oliva, J.L., Jiang, H., Penning, T.M., Kazanietz, M.G. (2007) Benzo[a]pyrene-7,8-dihydrodiol promotes checkpoint activation and $\mathrm{G}_{2} / \mathrm{M}$ arrest in human bronchoalveolar carcinoma $\mathrm{H} 358$ cells. Mol Pharmacol 71, 744-750. 
72. Davila, D.R., Romero, D.L., Burchiel, S.W. (1996) Human T cells are highly sensitive to suppression of mitogenesis by polycyclic aromatic hydrocarbons and this effect is differentially reversed by alphanaphthoflavone. Toxicol Appl Pharmacol 139, 333-341.

73. Drukteinis, J.S., Medrano, T., Ablordeppey, E.A., Kitzman, J.M., Shiverick, K.T. (2005) Benzo[a]pyrene, but not 2,3,7,8-TCDD, induces $\mathrm{G}_{2} / \mathrm{M}$ cell cycle arrest, p21CIP1 and p53 phosphorylation in human choriocarcinoma JEG-3 cells: a distinct signaling pathway. Placenta 26 Suppl A, S87-S95.

74. Guo, N., Faller, D.V., Vaziri, C. (2000) A novel DNA damage checkpoint involving post-transcriptional regulation of cyclin A expression. J Biol Chem 275, 1715-1722.

75. Hockley, S.L., Arlt, V.M., Brewer, D., Giddings, I., Phillips, D.H. (2006) Time- and concentration-dependent changes in gene expression induced by benzo(a)pyrene in two human cell lines, MCF-7 and HepG2. BMC Genomics 7, 260-

76. Hwang, J.A., Lee, J.A., Cheong, S.W., Youn, H.J., Park, J.H. (2007) Benzo(a)pyrene inhibits growth and functional differentiation of mouse bone marrow-derived dendritic cells Downregulation of RelB and elF3 p170 by benzo(a)pyrene. Toxicol Lett 169, 82-90.

77. Jeffy, B.D., Schultz, E.U., Selmin, O., Gudas, J.M., Bowden, G.T., Romagnolo, D. (1999) Inhibition of BRCA1 expression by benzo[a]pyrene and its diol epoxide. Mol Carcinog 26, 100-118.

78. Sadikovic, B., Rodenhiser, D.I. (2006) Benzopyrene exposure disrupts DNA methylation and growth dynamics in breast cancer cells. Toxicol Appl Pharmacol 216, 458-468.

79. Zhang, L., Shiverick, K.T. (1997) Benzo(a)pyrene, but not 2,3,7,8-tetrachlorodibenzo-p-dioxin, alters cell proliferation and c-myc and growth factor expression in human placental choriocarcinoma JEG-3 cells. Biochem Biophys Res Commun 231, 117-120.

80. Wiger, R., Finstad, H.S., Hongslo, J.K., Haug, K., Holme, J.A. (1997) Paracetamol inhibits cell cycling and induces apoptosis in HL-60 cells. Pharmacol Toxicol 81, 285-293.

81. Tuschl, H., Schwab, C.E. (2005) The use of flow cytometric methods in acute and long-term in vitro testing. Toxicol In Vitro 19, 845-852.

82. Reilly, T.P., Bourdi, M., Brady, J.N., Pise-Masison, C.A., Radonovich, M.F., George, J.W., Pohl, L.R. (2001) Expression profiling of acetaminophen liver toxicity in mice using microarray technology. Biochem Biophys Res Commun 282, 321-328.

83. Williams, D.P., Garcia-Allan, C., Hanton, G., LeNet, J.L., Provost, J.P., Brain, P., Walsh, R., Johnston, G.I., Smith, D.A., Park, B.K. (2004) Time course toxicogenomic profiles in CD-1 mice after nontoxic and nonlethal hepatotoxic paracetamol administration. Chem Res Toxicol 17, 1551-1561.

84. Masson, M.J., Peterson, R.A., Chung, C.J., Graf, M.L., Carpenter, L.D., Ambroso, J.L., Krull, D.L., Sciarrotta, J., Pohl, L.R. (2007) Lymphocyte loss and immunosuppression following acetaminophen-induced hepatotoxicity in mice as a potential mechanism of tolerance. Chem Res Toxicol 20, 20-26.

85. Mahadevan, B., Keshava, C., Musafia-Jeknic, T., Pecaj, A., Weston, A., Baird, W.M. (2005) Altered gene expression patterns in MCF-7 cells induced by the urban dust particulate complex mixture standard reference material 1649a. Cancer Res 65, 1251-1258.

86. Jeffy, B.D., Chirnomas, R.B., Chen, E.J., Gudas, J.M., Romagnolo, D.F. (2002) Activation of the aromatic hydrocarbon receptor pathway is not sufficient for transcriptional repression of BRCA-1: requirements for metabolism of benzo[a]pyrene to 7r,8t-dihydroxy-9t,10-epoxy-7,8,9,10-tetrahydrobenzo[a]pyrene. Cancer Res $62,113-121$.

87. Zhu, H., Smith, C., Ansah, C., Gooderham, N.J. (2005) Responses of genes involved in cell cycle control to diverse DNA damaging chemicals in human lung adenocarcinoma A549 cells. Cancer Cell Int 5, 28-

88. Affleck, J.G., Neumann, K., Wong, L., Walker, V.K. (2006) The effects of methotrexate on Drosophila development, female fecundity, and gene expression. Toxicol Sci 89, 495-503.

89. Denoyelle, C., Albanese, P., Uzan, G., Hong, L., Vannier, J.P., Soria, J., Soria, C. (2003) Molecular mechanism of the anti-cancer activity of cerivastatin, an inhibitor of HMG-CoA reductase, on aggressive human breast cancer cells. Cell Signal 15, 327-338.

90. Sun, A., Shanmugam, I., Song, J., Terranova, P.F., Thrasher, J.B., Li, B. (2007) Lithium suppresses cell proliferation by interrupting E2F-DNA interaction and subsequently reducing S-phase gene expression in prostate cancer. Prostate 67, 976-988.

91. Ullmannova, V., Popescu, N.C. (2007) Inhibition of cell proliferation, induction of apoptosis, reactivation of DLC1, and modulation of other gene expression by dietary flavone in breast cancer cell lines. Cancer Detect Prev 31, 110-118.

92. Zhang, J.P., Ying, K., Xiao, Z.Y., Zhou, B., Huang, Q.S., Wu, H.M., Yin, M., Xie, Y., Mao, Y.M., Rui, Y.C. (2004) Analysis of gene expression profiles in human HL-60 cell exposed to cantharidin using cDNA microarray. Int J Cancer 108, 212-218.

93. Pearse, G. (2006) Histopathology of the thymus. Toxicol Pathol 34, 515-547. 




\section{$(8$}

Evaluation of immunomodulation by Lactobacillus casei Shirota: immune function, autoimmunity, and gene expression

International Journal of Food Microbiology (2006) 112: 8-18

K.A. Baken ${ }^{1,2}$

J. Ezendam ${ }^{2}$

E.R. Gremmer ${ }^{2}$

A. de Klerk ${ }^{2}$

J.L.A. Pennings ${ }^{2}$

B. Matthee ${ }^{2}$

A.A.C.M. Peijnenburg ${ }^{3}$

$\mathrm{H}$. van Loveren ${ }^{1,2}$

\footnotetext{
${ }^{1}$ Department of Health Risk Analysis and Toxicology, Maastricht University, Maastricht, The Netherlands ${ }^{2}$ Department of Toxicology, Pathology and Genetics, National Institute for Public Health and the Environment, Bilthoven, The Netherlands

${ }^{3}$ RIKILT-Institute of Food Safety, Wageningen University and Research Centre, Wageningen, The Netherlands
} 


\title{
Chapter 6
}

\begin{abstract}
Lactic acid bacteria are claimed to have immunomodulating effects. Stimulation as well as suppression of $\mathrm{T}$ helper (Th)1-mediated immune responses, have been described for various strains. Experiments involving Lactobacillus casei Shirota (LCS) detected mainly enhancement of innate immune responses and promotion of Th1-mediated immune reactivity. To confirm and further investigate modulation of Th1 responses and development of autoimmune disease by LCS, the consequences of oral administration of LcS were assessed in several experiments. The effect of LcS varied between the different models. No modulation was found in the mitogen-induced cell proliferation and cytokine release assays in mesenteric lymph nodes of Wistar rats. LcS inhibited the Th1-mediated immune response in an adapted murine Local Lymph Node Assay (LLNA) in BALB/c mice, whereas Experimental Autoimmune Encephalomyelitis (EAE) in Lewis rats was aggravated. These varying effects on Th1 responses indicate that beneficial as well as harmful effects on immune-related disorders could occur after LcS consumption. Since microarray analysis is suggested to be more sensitive and predictive than functional tests, gene expression profiling was included as an alternative endpoint in the testing of immunomodulation. The detected gene expression profiles did not reflect the effects of LcS on the immune system. Microarray analysis may therefore have no more predictive value than immune function assays when investigating immunomodulation by probiotics. To gain further insight into effects of probiotics on immune function, experiments including cytokine assays and gene expression analysis combined with disease models could be useful.
\end{abstract}




\section{Introduction}

Since the beginning of the previous century, various health promoting effects of human consumption of probiotic bacteria have been described $[1,2]$. Numerous experiments have indicated that (changes in) the intestinal microbiota can cause immunomodulation, both at the intestinal and the systemic level $[3,4]$. Especially lactic acid bacteria (LAB), that are part of the human commensal microbiota and that have a long history of use in food products, have been studied widely. The ability of several LAB strains to modulate host innate as well as acquired immune responses, has been demonstrated in many in vitro experiments and animal models. Besides stimulation of antibody production [5] and macrophage activity [6], functional effects like inhibition of inflammation $[7,8]$, intestinal infections [9,10], allergic disease symptoms [11-13] and autoimmune disorders [2] were observed. This resulted in claims concerning beneficial effects of $L A B$ on some clinical conditions and on immune reactiveness $[2,14,15]$.

Immunoregulatory effects of probiotics have often been ascribed to a shift of the T helper (Th)1/Th2 balance towards Th1-mediated immunity. Release of the Th1 associated cytokines interleukin (IL)-12, interferon (IFN)- $\mathrm{y}$ and tumor necrosis factor (TNF)- $\beta$ by various cell types was repeatedly demonstrated to be increased by LAB [1623]. Moreover, several LAB reduced production of Th2-related cytokines [20]. The skewing towards Th1 may inhibit the development of allergies, as was confirmed by suppression of immunoglobulin (Ig)E production by LAB in animal allergy models [24,25]. At the same time, some concern exists that this shift could be associated with stimulation of certain autoimmune diseases [26]. Indeed, the development of Experimental Autoimmune Encephalomyelitis (EAE) was found to be stimulated by oral administration of $L$. reuteri to mice [27].

To confirm modulation of Th1-mediated immune responses by LAB and to assess possible harmful consequences for autoimmunity, we performed experiments with Lactobacillus casei Shirota (LCS). LCS is a non-pathogenic bacterial strain from human origin of which the impact on the immune system was investigated in a variety of studies. Its effects on innate immune responses were mainly stimulatory, as reflected by promotion of phagocytosis [28] and enhancement of natural killer (NK) cell cytotoxicity [29-34]. LcS was also shown to promote Th1-mediated responses $[35,36]$. This took shape in increased splenic release of Th1 associated cytokines like IFN-y and IL-12, and down-regulation of IL-4 and IgE levels [25,35,37-40]. In line with these effects, LcS administration suppressed systemic allergic reactions in a food allergy model [25]. In contrast, LcS as well as other LAB suppressed the severity of autoimmune disease in animal models for diabetes and arthritis [41-46]. This was explained by effects on both cellular (improved macrophage recruitment, inhibition of T cell proliferation, reduced IL-6 and IFN-y production, increased IL-10 and IL-12 release) and humoral (less auto-antibodies) responses.

We examined the immunomodulatory capacity of LcS in several assays. The murine Local Lymph Node Assay (LLNA) is a validated test method used for identification of compounds with sensitizing potential [47]. A modified LLNA was applied to determine effects of oral exposure to LCS on systemic immune reactivity, as was described for other immunomodulating compounds previously [48]. Lymphocyte proliferation in draining lymph nodes after application of a T cell-dependent contact sensitizer was used as a measure for Th1 responsiveness. The influence of LcS administration on the Th1-mediated immune 
response was also studied in rats in which $E A E$ was induced. $E A E$, which is an experimental model for multiple sclerosis, is assumed to be induced by activation of autoreactive Th1 cells that recognize myelin basic protein (MBP), which causes inflammatory demyelination in the central nervous system leading to transient paralysis [49]. Effects of oral LcS exposure on cell proliferation and cytokine release in mesenteric lymph nodes (MLN) were assessed in Wistar rats. The last approach to examine immunomodulation by oral administration of LcS was microarray analysis. Specific changes in gene expression are supposed to be more sensitive and accurate endpoints than traditional endpoints when investigating an organism's response to a certain exposure [50,51]. Therefore, we included gene expression profiling in MLN, spleen, liver and thymus of rats to obtain a global view on the effects of LcS on the immune system and to possibly provide insight into genes and cellular pathways involved [52]. Varying effects of LcS exposure on the (Th1-mediated) immune responses were detected in the different assays.

\section{Materials and methods}

\section{Bacteria}

Lactobacillus casei strain Shirota (isolated from a commercially available LcS-containing drink) was cultured for $48 \mathrm{~h}$ at $30{ }^{\circ} \mathrm{C}$ under anaerobic conditions in Man Rogosa Sharpe (MRS) broth (CM359; Oxoid, Haarlem, The Netherlands). Thereafter, bacteria were washed twice with saline $(0.9 \% \mathrm{NaCl})$ containing $1 \mathrm{mg} / \mathrm{ml}$ peptone (saline/peptone) and resuspended in saline/peptone to a final concentration of either $1 \times 10^{9} \mathrm{CFU} / \mathrm{ml}$ (experiments in rats) or $2 \times 10^{9} \mathrm{CFU} / \mathrm{ml}$ (experiments in mice). The number and viability of the Lactobacilli were determined by aerobic culturing on MRS plates (Oxoid CM361) for 72 h. In all experiments, LcS was administered orally by means of intragastric dosing.

\section{Immune function test in mice}

\section{ANIMALS}

Young adult (6-8 weeks old) male BALB/c mice were obtained from the institute's own breeding colony. The animals were bred specific pathogen free (SPF) and kept in macrolon cages under conventional conditions. The mice were fed Hope Farms chow pellets (Woerden, The Netherlands) and water ad libitum during the whole experiment. The experimental setup of the study was examined and agreed upon by the institute's Ethical Committee on Experimental Animals, according to national legislation.

\section{LCS TREATMENT AND SENSITIZATION}

The animals were randomly divided in 2 groups of 16 mice. Daily administration of LcS or saline/peptone $(0.1 \mathrm{ml})$ by gavage started 8 days prior to sensitization with 2,4dinitrochlorobenzene (DNCB) (98\%; Sigma-Aldrich, Zwijndrecht, The Netherlands). Four mice of each group were selected for topical exposure to one of the DNCB concentrations 
dissolved in acetone:olive oil $(4: 1)(A O O)$ on the dorsum of both ears $(25 \mu \mathrm{l})$. The DNCB concentrations used were $1 \%, 0.66 \%, 0.33 \%$ and $0 \%(w / v)$. DNCB application was performed daily for three consecutive days.

\section{Cell isolation}

In contrast to the LLNA, lymphocytes in the auricular lymph nodes were not labeled with $\left[{ }^{3} \mathrm{H}\right]$-thymidine in vivo, but harvested and labeled ex vivo. Three days after the last topical application of $\mathrm{DNCB}$, the mice were euthanized by $\mathrm{CO}_{2} / \mathrm{O}_{2}$ exposure and the auricular lymph nodes (LN) were excised, pooled for each animal, weighed and suspended in $5 \mathrm{ml}$ RPMI 1640 (Gibco, Life Technologies, Breda, The Netherlands) with 5\% heat inactivated Fetal Calf Serum (FCS) (PAA, Linz, Austria), $100 \mathrm{U} / \mathrm{ml}$ penicillin and $100 \mathrm{\mu g} / \mathrm{ml}$ streptomycin (standard medium). Single cell suspensions were prepared under aseptic conditions by pressing the LN trough a $70 \mu \mathrm{m}$ nylon cell strainer (Falcon, Franklin Lakes, USA). The cells were washed twice in standard medium $\left(10 \min 300 \mathrm{~g}, 4{ }^{\circ} \mathrm{C}\right.$ ) and resuspended in $1 \mathrm{ml}$ standard medium with 10\% FCS. A Coulter Counter (Z2, Coulter Electronics, Mijdrecht, The Netherlands) was used to count the cells. Then the concentration of the cell suspensions was adjusted to $1 \times 10^{7} \mathrm{cells} / \mathrm{ml}$.

\section{Cell PROLifERATION}

Of each cell suspension of $1 \times 10^{7}$ cells $/ \mathrm{ml}, 200 \mu \mathrm{l}$ was seeded in triplicate in a U-bottom 96-wells plate (Greiner, Alphen aan den Rijn, The Netherlands). After addition of $10 \mu \mathrm{l} /$ well $(=1 \mu \mathrm{Ci})\left[\right.$ methyl- $\left.{ }^{3} \mathrm{H}\right]$-thymidine (Amersham Biosciences, Buckinghamshire, UK) the cells were incubated at $37{ }^{\circ} \mathrm{C}$ in a humidified atmosphere containing $5 \% \mathrm{CO}_{2}$ during 20-24 h. The cells were harvested on glass-fiber filters (LKB-Wallac, Turku, Finland) using a multiple cell culture harvester (LKB-Wallac). The $\left[{ }^{3} \mathrm{H}\right]$-thymidine activity was determined using a liquid scintillation counter (1205 Betaplate TM, LKB-Wallac). For further calculations the median of the triplicates was used. The $\left[{ }^{3} \mathrm{H}\right]$-thymidine incorporation is expressed per animal, being the measured counts per minute (cpm) times the cell number of the two $L N$ and divided by the cell number in culture. The total experiment was repeated once, using 4 mice more in both $0 \%$ DNCB groups. The results of the two experiments were pooled and the mean $\left[{ }^{3} \mathrm{H}\right]$-thymidine incorporation per experimental group \pm SEM was calculated. Statistical analysis was performed using one-way analysis of variance (ANOVA). Significant differences of the control group were determined with the Bonferroni post hoc test, using a significance level of $p=0.05$.

\section{Immune function tests in rats}

\section{EAE}

\section{ANIMALS}

Six to eight week old SPF male Lewis rats (LEW/HanHsD) were obtained from Harlan (Horst, The Netherlands). Rats were housed individually under standard conditions with water and food ad libitum. The animals were allowed to acclimatize one week before starting the experiment. The experimental setup of the study was examined and agreed 
upon by the institute's Ethical Committee on Experimental Animals, according to national legislation.

\section{INDUCTION OF EAE}

Rats were randomly divided in two experimental groups ( $n=8$ per group), either or not receiving LcS orally. Daily LcS administration started 8 days prior to the induction of EAE and continued during the course of the experiment. Rats received $1 \mathrm{ml}$ of LcS $\left(1 \times 10^{9}\right.$ $\mathrm{CFU} / \mathrm{ml}$ ) or saline/peptone (controls). Acute EAE was induced in both experimental groups by subcutaneous injection of $50 \mu \mathrm{l}$ emulsion containing $1 \mathrm{~g} / \mathrm{ml}$ guinea pig spinal cord homogenate and $10 \mathrm{mg} / \mathrm{ml}$ Mycobacterium tuberculosis type H37RA (Difco, Detroit, USA) suspended in equal amounts of complete Freund's adjuvant (CFA, Difco) and saline (0.9\% $\mathrm{NaCl}$ ). EAE injections were performed under halothane anesthesia. After induction of $E A E$ body weight was recorded daily for 28 days. Also, neurological signs were scored daily during 28 days and graded from 1 to 5 : 0 , no clinical signs; 0.5 , loss of tonicity in distal half of tail; 1 , flaccid tail; 1.5 , unsteady gait; 2 , partial hind limb paralysis; 2.5 , complete hind limb paralysis; 3, paralysis of the complete lower part of the body up to the diaphragm; 4, paraplegia; and 5 , death due to EAE.

\section{STATISTICAL ANALYSIS}

Mean body weights \pm SEM were calculated for LcS-treated and control rats on all 28 days. Significant differences between both experimental groups were determined per day with a two-tailed Student's t-test (significance level $p=0.05$ ). The clinical scores per animal were added over time and averaged per day $( \pm S E M)$ to display the progress of the disease. The significance of the difference of these cumulative scores between the groups was calculated per day using a one-tailed Mann-Whitney Test (significance level $p=0.05$ ). The same test was used to analyze the duration of EAE, defined by the amount of days with clinical signs of EAE per animal. For both groups a Cumulative Disease Index (CDI) was determined, being the sum of the cumulative daily scores per group divided by the amount of days that clinical disease signs were observed in the group.

\section{CELL PROLIFERATION AND CYTOKINE RELEASE ASSAYS}

\section{ANIMALS}

Male 17-week old Wistar WU(CPB) rats $(n=16)$ were obtained from our own breeding colony (RIVM CDL-D5a/b). The rats were bred SPF and kept in macrolon cages under tightly controlled standardized conditions. Water and food pellets were available ad libitum. The experimental setup of the study was examined and agreed upon by the institute's Ethical Committee on Experimental Animals, according to national legislation.

\section{EXPERIMENTAL DESIGN}

The animals were randomly assigned to two experimental groups $(n=8)$, receiving either 1 $\mathrm{ml}$ of LCS $\left(1 \times 10^{9} \mathrm{CFU} / \mathrm{ml}\right)$ or $1 \mathrm{ml}$ saline/peptone (controls) by gavage. At the 8 th day of the experiment, the animals were euthanized by $\mathrm{CO}_{2} / \mathrm{O}_{2}$ exposure and weighed. Dissection took place and spleen, liver, thymus and MLN were collected and weighed. The MLN were split in two and both halves were weighed. One half was immediately snap frozen in liquid nitrogen, as were the spleen, liver and thymus. The other half was kept in 
standard medium on ice until further processing for immune function tests. The frozen organs were stored at $-80^{\circ} \mathrm{C}$ until use in RNA isolation (see below).

\section{LYMPHOCYTE TRANSFORMATION TEST}

For determination of mitogen-induced cell proliferation in the MLN, the same protocol as described for the LLNA was used, only here $100 \mu \mathrm{l}$ of a cell suspension of $4 \times 10^{6} \mathrm{cells} / \mathrm{ml}$ was added per well and proliferation was assessed after 72 and $96 \mathrm{~h}$ of incubation with 50 $\mu \mathrm{l}$ of the mitogens Concavalin A (ConA; $3.33 \mu \mathrm{g} / \mathrm{ml}$, ICN Biochemicals), lipopolysaccharide (LPS, $16.7 \mu \mathrm{g} / \mathrm{ml}$, Sigma), phytohaemagglutinin (PHA; 1:25, Murex Biotech, Dartford, UK) and pokeweed mitogen (PWM; $1.67 \mu \mathrm{g} / \mathrm{ml}$, Gibco Life Technologies). [ $\left.{ }^{3} \mathrm{H}\right]$-thymidine was added for the last 20-22 $\mathrm{h}$ of incubation.

\section{IL-4 AND IFN-Y RELEASE}

To measure IL-4 and IFN- $\gamma$ release, single cell suspensions of the MLN were cultured with ConA. Cell suspensions $\left(4 \times 10^{6}\right.$ cells/well) were seeded in 6-well plates (Greiner) and incubated with $5 \mu \mathrm{g} / \mathrm{ml}$ ConA for $48 \mathrm{~h}$ at $37^{\circ} \mathrm{C}, 5 \% \mathrm{CO}_{2}$. IL-4 and IFN-y concentrations in supernatants were determined by an enzyme-linked immunosorbent assay (ELISA). All monoclonal antibodies were obtained from Pharmingen (BD Biosciences, San Diego, USA) and ELISAs were performed according to the manufacturer's description with some minor modifications. Incubations were followed by extensive washing on an automatic plate washer (ELx405, BioTek Instruments, Winooski, USA) with PBS containing $0.1 \%$ Tween-20 (Merck, Amsterdam, the Netherlands). Briefly, 96-wells plates (Immuno Plate, Nunc, Roskilde, Denmark) were coated overnight at $4{ }^{\circ} \mathrm{C}$ with $2 \mu \mathrm{g} / \mathrm{ml}$ rat anti-mouse IFNY or $1 \mu \mathrm{g} / \mathrm{ml}$ rat anti-mouse IL-4 in $0.04 \mathrm{M}$ carbonate buffer, $\mathrm{pH}$ 9.6. Then the plates were blocked by adding a blocking solution (Sigma) that contained $0.05 \mathrm{M}$ Tris buffered saline with $1 \%$ bovine serum albumin (BSA, Sigma), $\mathrm{pH} 8.0$ for $2 \mathrm{~h}$ at $37^{\circ} \mathrm{C}$. After blocking, serial dilutions of recombinant mouse IFN- $\gamma$ or recombinant IL-4 and supernatants were added and incubated for $2 \mathrm{~h}$ at $37{ }^{\circ} \mathrm{C}$. Thereafter, biotinylated rat anti-mouse IFN- $\gamma(0.5 \mu \mathrm{g} / \mathrm{ml})$ or IL-4 $(0.5 \mu \mathrm{g} / \mathrm{ml})$ was added and incubated for $1 \mathrm{~h}$ at room temperature (RT), followed by incubation with poly horseradish peroxidase labeled streptavidin (CLB, Amsterdam, The Netherlands) for $45 \mathrm{~min}$ at RT. Plates were washed again and tetramethylbenzidine (TMB) solution $\left(0.1 \mathrm{mg} / \mathrm{ml} \mathrm{TMB}\right.$ (Sigma) plus $0.006 \% \mathrm{H}_{2} \mathrm{O}_{2}$, in $0.1 \mathrm{M} \mathrm{NaAc}, \mathrm{pH} 5.5$ ) was added. This coloring reaction was terminated with $\mathrm{H}_{2} \mathrm{SO}_{4}(10 \%$, Merck) and absorbance was read at $450 \mathrm{~nm}$ using an automated multichannel photometer (Titertek Multiscan MCC/340,Huntsville, USA). Standard curves of recombinant IFN-y or IL-4 were used to calculate the amount of cytokines. Results are expressed per animal, i.e. the response is multiplied by the total LN cell number, and divided by the cell culture concentration.

\section{STATISTICAL ANALYSIS}

Significant differences between the two groups in animal and organ weights, MLN cell numbers, mitogen-induced cell proliferation and cytokine production were determined with a two-tailed Student's t-test using a significance level of $p=0.05$. Absolute organ weights as well as relative weights (organs weights divided by body weights) were analyzed. 


\section{Gene expression analysis}

\section{EXPERIMENTAL DESIGN}

Gene expression analysis was performed in the snap frozen spleen, liver, thymus and MLN halves from the male 17-week old Wistar WU(CPB) rats $(n=16)$ that were used for the cell proliferation and cytokine release assays. These animals had received either $1 \mathrm{ml}$ of LcS $\left(1 \times 10^{9} \mathrm{CFU} / \mathrm{ml}\right)$ or $1 \mathrm{ml}$ saline/peptone (controls) by gavage during 8 days.

\section{RNA ISOLATION}

Total RNA was isolated from the collected organs with a commercially available kit (RNeasy, Qiagen, Venlo, The Netherlands) in combination with DNase treatment (RNaseFree DNase Set, Qiagen) according to the manufacturer's instructions. To start the procedure, a part of the frozen organ was split off using a mortar and pestle cooled by liquid nitrogen. This piece was then placed in the lysis buffer and immediately disrupted and homogenized using a rotor-stator homogenizer (Diax 900 10G, Heidolph, Schwabach, Germany). Quantity of RNA was assessed spectrophotometrically (ND1000, NanoDrop Technologies, Wilmington, USA) and RNA integrity was measured with automated gel electrophoresis (Bioanalyzer 2100, Agilent Technologies, Amstelveen, The Netherlands). The concentration of all rat RNA samples was adjusted to $2.5 \mu \mathrm{g} / \mu \mathrm{l}$ by vacuum drying and addition of RNase free water (Qiagen). For each organ a reference pool was prepared by pooling equal amounts of RNA from all animals $(n=16)$. The RNA yield from MLN was not sufficient to perform microarray analysis and therefore amplified with an amplification kit (Amino Allyl MessageAmp aRNA kit, Ambion, Austin, USA). All RNA samples were stored at $-80^{\circ} \mathrm{C}$ until microarray analysis.

\section{MICROARRAY ANALYSIS}

Microarray analysis was performed with RNA from five rats for one organ at a time. cDNA synthesis and labeling were performed using an indirect labeling method, involving incorporation of amino allyl-dUTP groups that bind fluorescent CyDye NHS-esters and purification of reaction products by means of spin columns (Cyscribe Post Labelling kit, CyDye Post Labelling Reactive Dye Pack and Cyscribe GFX Purification kit, Amersham Biosciences, Buckinghamshire, UK), according to the manufacturer's instructions. Cy5 was used to label $20 \mu \mathrm{g}$ of sample cDNA and equal aliquots of reference pool cDNA were labeled with Cy3 simultaneously. The volume of the purified labeled cDNAs was reduced to $12.5 \mu \mathrm{l}$, after which every sample was combined with a labeled aliquot of reference pool cDNA.

The Rat Array Ready Oligo Set v1.0 (Operon Biotechnologies GmbH, Cologne, Germany) containing 5,705 C6-amino-linked oligos representing rat genes was spotted in duplicate on silylated glass slides at the University Medical Centre Utrecht (UMC). Slides also contained appropriate controls and blank spots, which were used for quality control but not in further analyses. Pre-treatment and hybridization proceeded according to protocols developed at the UMC. Pre-treatement of the slides included successive washing in a $0.2 \%$ SDS (Ambion) solution, milliQ, $0.25 \mathrm{~g}$ of sodiumborohydride (Sigma) in $75 \mathrm{ml}$ phosphate buffered saline and $25 \mathrm{ml}$ ethanol, and $0.2 \%$ SDS and milliQ again. They 
were dried quickly and evenly by centrifugation at $1000 \mathrm{rpm}$ and stored in a dark moistureand dust-free exsiccator until cDNA hybridization. Then the slides were prehybridized at 42 ${ }^{\circ} \mathrm{C}$ for at least one hour in a solution [sterilized by filtering through a 0.22 micron filter (Millipore, Amsterdam, The Netherlands)] consisting of $12 \mathrm{ml} 2 x$ SSC (Invitrogen, Breda, The Netherlands), $0.5 \mathrm{ml} 10 \% \mathrm{SDS}, 0.5 \mathrm{~g} \mathrm{BSA}$ (Sigma), and $37 \mathrm{ml} \mathrm{milliQ}$, or a multiple of this. Just before hybridization, the slides were washed in milliQ and propanol and dried by centrifugation. Hybridization mixture was made of $2.55 \mathrm{ml}$ formamide (Sigma), $2.55 \mathrm{ml} 20 \mathrm{x}$ SSC and $0.1 \mathrm{ml} \mathrm{10 \%} \mathrm{SDS} \mathrm{(or} \mathrm{a} \mathrm{multiple} \mathrm{of} \mathrm{this),} \mathrm{filtered} \mathrm{through} \mathrm{a} 0.22$ micron filter and preheated to $42{ }^{\circ} \mathrm{C}$. Then $50 \mu \mathrm{g}$ salmon sperm (Gibco, Invitrogen) and $1.3 \mathrm{pmol}$ of a Cy3labeled 70-mer oligo complementary to a landmark control oligo [53] (Operon) were added to $250 \mu \mathrm{l}$ of the hybridization mix. Of this hybridization mix, $25 \mu \mathrm{l}$ was added to each $25 \mu \mathrm{l}$ of combined sample and reference cDNA, and the complete mixture was heated at $95{ }^{\circ} \mathrm{C}$ for $5 \mathrm{~min}$. Finally, $45 \mathrm{ml}$ of the cDNA mixture was pipetted onto the glass slide and spread evenly by application of a cover slip. This was incubated for approximately $18 \mathrm{~h}$ at $42{ }^{\circ} \mathrm{C}$ in the dark in humid hybridization chambers (GeneMachines Genomic Solutions Ltd., Cambridgeshire, UK).

Thereafter, slides were successively washed in $2 x \mathrm{SSC} / 0.1 \%$ SDS $\left(5 \min 42{ }^{\circ} \mathrm{C}\right.$, twice), $0.1 \times \mathrm{SSC} / 0.1 \% \mathrm{SDS}(5 \mathrm{~min})$ and $0.1 \mathrm{x}$ SSC (1 min, twice) with milliQ as vehicle. Immediately after drying, slides were scanned randomly using the Scanarray $4000 \mathrm{XL}$ (Perkin Elmer, Boston, USA) with appropriate laser and photo multiplier tube (PMT) settings. Array Vision software (Imaging Research, St. Catherines, Ontario, Canada) was used to determine Cy3 and Cy5 signal intensities for each separate spot and background noise. Quality control was performed on raw data by means of a scatter plot and MA-plot as well as a normal probability plot to assess signal distribution [54].

\section{DATA ANALYSIS}

Raw data were log-transformed and normalized by global LOESS correction of the $\ln ($ Сy5/Cy3) ratio using S-plus, where after data from replicate spots were averaged. Then the data were analyzed by Principal Component Analysis (PCA) using GeneMaths (Applied Maths, St-Martens-Latem, Belgium) and statistical analysis using Microsoft Excel. Differences in gene expression between the two experimental groups were calculated with the two-tailed Student's t-test. Also, a fold ratio in gene expression (FR) was determined by dividing the average normalized signal value of a gene in the LcS group by this value of the same gene in the control group. For the 5 most significantly up- and down-regulated genes and the genes with a FR $\geq 1.5$, clustering and cellular pathway enrichment were investigated with GeneMaths and the Expression Analysis Systematic Explorer (EASE, http://david.abcc.ncifcrf.gov/ease/ease.jsp), respectively. 


\section{Results}

Immune function test in mice

The effect of LcS administration on DNCB induced lymphocyte proliferation in draining LN of $B A L B / c$ mice is shown in Figure 1 . The mean $\left[{ }^{3} \mathrm{H}\right]$-thymidine incorporation $\pm S E M$ is depicted per DNCB concentration for both experimental groups. Only at the highest concentration of $1 \%$ DNCB, LCS significantly reduced the cell proliferation in $L N$ ( $p$ $=0.005)$.

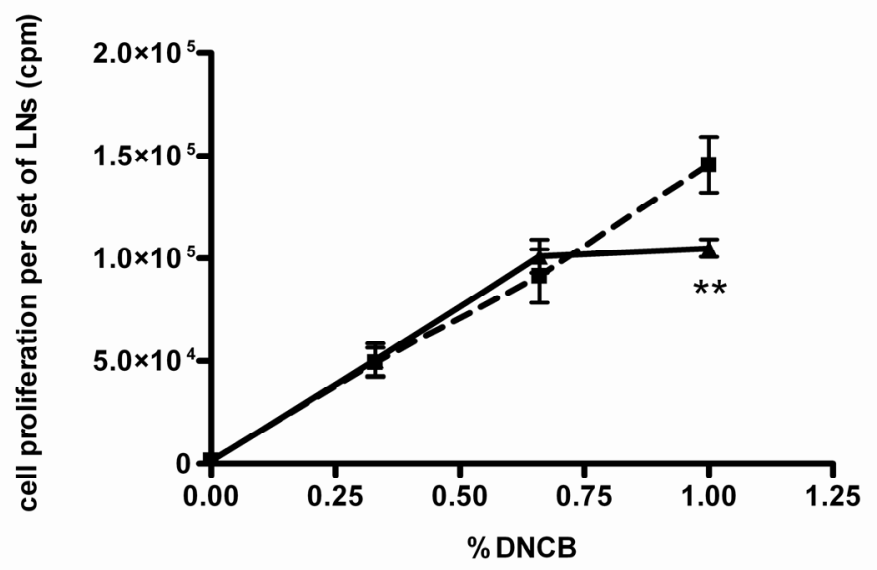

Figure 1.

$\left[{ }^{3} \mathrm{H}\right]$-thymidine incorporation in auricular LN cells of male BALB/c mice after oral administration of LcS. LcS administration to the mice $(n=16)$ started 8 days before sensitization. These mice $(\boldsymbol{\Delta})$ as well as the control animals $(\boldsymbol{\square})$ (similar group size) were then subdivided in groups $(n=4)$ for sensitization with four different DNCB concentrations $(0 \%, 0.33 \%, 0.66 \%$ and $1 \%)$. The $\left[{ }^{3} \mathrm{H}\right]$-thymidine incorporation was expressed in counts per minute (cpm) per set of auricular LN times the total LN cell number. The results were pooled with data from a similar experiment involving 4 mice more in the $0 \%$ DNCB groups. Figure 1 depicts the means \pm SEM of the measurements per group for these two experiments. Significance level is ${ }^{* *} p<0.01$. 
Immune function tests in rats

\section{EAE}

In the LcS-treated group, one rat died for unknown reasons before the first symptoms of EAE appeared, so results were obtained from the remaining 7 animals. The mean body weights per day for the LcS-treated and the control group during the 28 days after induction of EAE are shown in Figure 2. The body weight of both groups decreased after day 11. The weight of the control group increased again after day 15, whereas the LcS group did not recover until day 23. From day 16 onwards, the weights of the LcS-treated animals were significantly lower than those of the controls $(p=0.006-0.024)$. The first clinical disease symptoms appeared at day 12 in the LcS group, which was 4 days earlier than in the control group. After day 24 , the control animals seemed to have recovered from the EAE, while one animal in the LcS group still showed clinical signs at day 28. The extension of the duration of EAE by LcS was statistically significant $(p=0.038)$. Figure 3 shows the mean cumulative clinical scores per day for both experimental groups during the 28 days after EAE induction. At day 17 and 18 and from day 21 onwards, LCS increased the clinical score significantly $(p=0.0256-0.0495)$. The CDI of the LcS-treated animals was 1.2, which was higher than the CDI of 0.9 in the control group. The incidence of rats with disease symptoms during the experiment was $100 \%$ in the LCS group vs. $75 \%$ in the control group. Table 1 summarizes the day of onset of the disease, the incidence of $E A E$, the duration of the disease, the mean of the cumulative scores per animal at the end of the experiment and the CDI for both experimental groups.

\section{CELL PROLIFERATION AND CYTOKINE RELEASE ASSAYS}

During 8 successive days of oral administration of either LcS or a control solution, all Wistar WU(CPB) rats showed a non-significant reduction of body weight. Absolute organ weights were not affected by LCS administration, nor were relative organ weights except for spleen. LcS caused a slight but significant increase of the relative spleen weight after 8 days of treatment $(p=0.023)$. In Table 2 , the body weights at the start and the end of the experiment and the absolute and relative spleen weights are summarized for both experimental groups. The cell number of MLN and their mitogen induced proliferation or IFN- $\gamma$ release did not differ between both experimental groups. Mitogen-induced IL-4 was not detected in any sample in this experiment. 

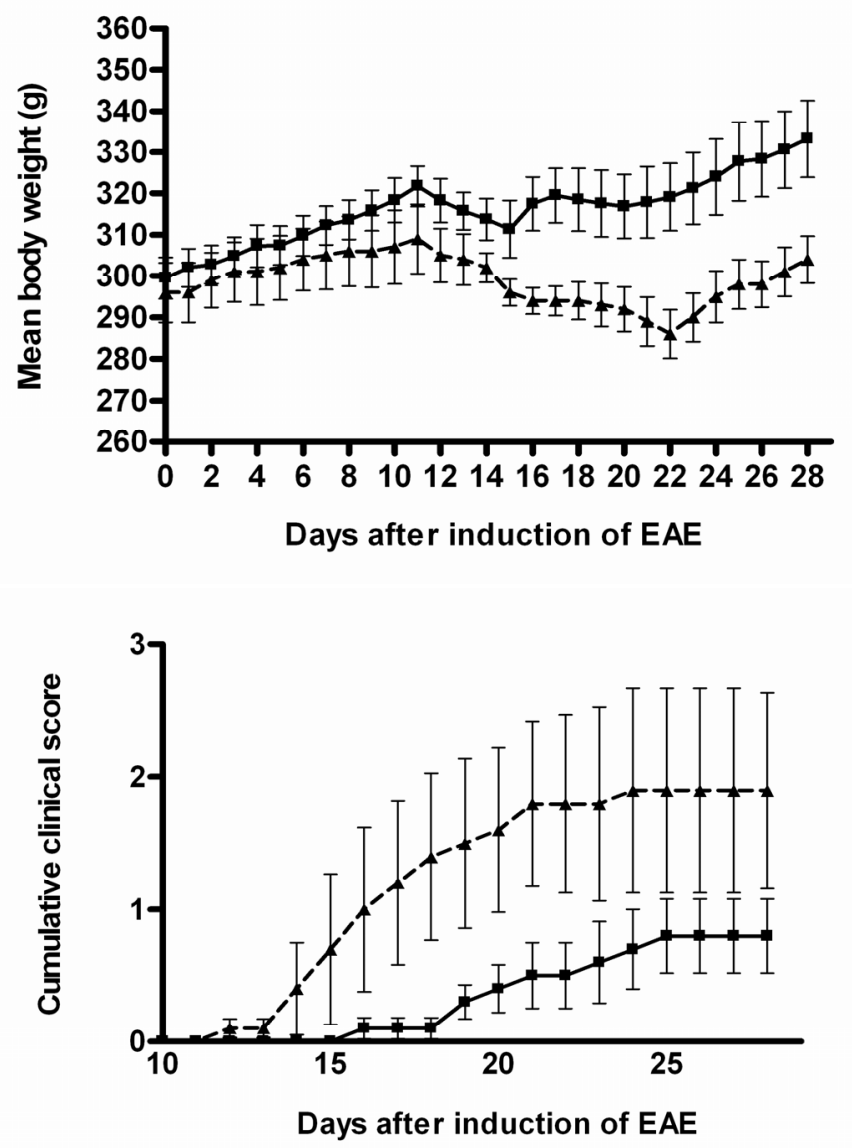

Figure 2.

Mean body weights \pm SEM of LcS-treated $(\boldsymbol{\Lambda}, \mathrm{n}=7)$ and control ( $\mathbf{m}, \mathrm{n}=8$ ) 6-8 week old male Lewis rats during the 28 days after induction of EAE. LCS was administered orally from 8 days before induction of EAE until the end of the experiment. From day 16 onwards, body weight is significantly reduced in the LcS group ( $p=0.006-0.024)$.

\section{Figure 3.}

Mean cumulative clinical scores \pm SEM per day from 10 to 28 days after induction of EAE in 6-8 week old male Lewis rats. Clinical disease symptoms were scored daily in the LcS-treated $(\boldsymbol{\Lambda}, \mathrm{n}=7)$ and control $(\mathbf{a}, \mathrm{n}=8)$ rats and added over time per animal. At day 17 and 18 and from day 21 onwards, the increase of the cumulative clinical scores by LcS is statistically significant ( $p=0.0256-0.0495)$. 
Table 1.

Effects of oral LCS exposure on clinical parameters of EAE in rats.

\begin{tabular}{llllll}
\hline Group & Day of onset & Incidence & $\begin{array}{l}\text { Mean duration } \\
\text { of EAE }\end{array}$ & $\begin{array}{l}\text { Mean clinical score } \\
\text { per animal }\end{array}$ & CDI \\
\hline Control & 16 & $75 \%$ & $1.5 \pm 1.6$ & $0.8 \pm 0.8$ & 0.9 \\
LcS & 12 & $100 \%$ & $3.7 \pm 2.7^{*}$ & $2.2 \pm 1.7^{*}$ & 1.2 \\
\hline
\end{tabular}

Oral LcS administration started 8 days before induction of EAE in control $(n=8)$ and LcS-treated $(n=7)$ 6-8 week old male Lewis rats. During the following 28 days clinical disease signs were scored. Here, the day of onset of EAE (expressed as the first day that clinical signs were observed in each group), the incidence of animals with clinical disease signs, the mean duration of EAE $\pm S D$, the mean of the cumulative clinical scores per animal at the end of the experiment $\pm S D$, and the Cumulative Disease Index (CDI) for both experimental groups are shown. LCS significantly increased the duration of EAE and the cumulative score per animal $\left({ }^{*} p<0.05\right)$.

Table 2.

Effects of oral LCS exposure on body weight and spleen weight in rats.

\begin{tabular}{lllll}
\hline Group & $\begin{array}{l}\text { Body weight } \\
\text { (day 1) }\end{array}$ & $\begin{array}{l}\text { Body weight } \\
\text { (day 8) }\end{array}$ & $\begin{array}{l}\text { Spleen weight } \\
\text { (absolute) }\end{array}$ & $\begin{array}{l}\text { Spleen weight } \\
\text { (relative) }\end{array}$ \\
\hline Control & $436 \pm 18$ & $428 \pm 23$ & $0.70 \pm 0.06$ & $0.16 \pm 0.02$ \\
LcS & $460 \pm 39$ & $445 \pm 46$ & $0.77 \pm 0.10$ & $0.17 \pm 0.02$ * \\
\hline
\end{tabular}

Mean body weights of 17-week old male Wistar WU(CPB) rats before and after oral administration of LCS $(n=8)$ or a control solution $(n=8)$ during 8 successive days are displayed, as well as the absolute and relative spleen weights after 8 days (all weights in grams $\pm S D$ ). The relative spleen weight was significantly increased by LcS $\left.{ }^{*} p<0.05\right)$.

\section{Gene expression analysis}

All microarrays fulfilled our established quality parameters. PCA on raw data of all microarrays indicated one outlier in the $5 \mathrm{MLN}$ samples of the control group, which was excluded from further data analysis. Differences in gene expression between the control and LcS exposed rats were generally small. The ten most up- and down-regulated genes per organ had calculated $p$-values roughly ranging from 0.01 to 0.04 . For any chosen $p$ value, the number of significantly regulated genes barely exceeded the expected amount of false positive findings, regardless of assumption of equal variances. In addition, the FR did not exceed 2 in any organ. Fixing the FR at 1.5 resulted in 3 down-regulated genes in the MLN and 2 in the spleen, whereas the liver showed 4 down- and 2 up-regulated genes and the thymus 8 up-regulated genes after oral LcS administration. Table 3-6 present the ten most significantly regulated genes and the genes with $F R \geq 1.5$ per organ including their p-values and FRs for spleen, liver, thymus and MLN, respectively. In these groups of genes no enrichment of cellular pathways was found. Besides, the sets hardly contain any genes that can be related to known effects of LcS. 
Table 3.

Effects of oral LcS exposure on gene expression in rat spleen.

\begin{tabular}{lllcc}
\hline GenBank & Symbol & Gene name & p-value & FR \\
\hline U67080 & St18 & suppression of tumorigenicity 18 & 0,000 & -1.1 \\
X78603 & Arfrp1 & ADP-ribosylation factor related protein 1 & 0.001 & 1.1 \\
BF549820 & & ESTs, Highly similar to ethanol decreased 4 [M.musulus] & 0.001 & -1.2 \\
BE112689 & & ESTs, Highly similar to hypothetical protein FLJ20323 & 0.001 & 1.1 \\
& & [H.sapiens] & 0.001 & 1.2 \\
AF366899 & Adra2b & Adrenergic, alpha2B-, receptor class III & 0.001 & 1.2 \\
NM_031019 & Crh & Corticotropin releasing hormone & 0.002 & -1.1 \\
NM_022700 & Arl3 & ADP-ribosylation-like 3 & 0.002 & 1.1 \\
NM_012653 & Slc9a2 & Solute carrier family 9 (Na+/H+ exchanger 2), antiporter 2 & 0.003 & -1.2 \\
NM_023102 & Csnk1g2 & Casein kinase 1 gamma 2 isoform & 0.006 & -1.2 \\
NM_031324 & Prep & Prolyl endopeptidase & 0.013 & -1.5 \\
X82152 & Fmod & Fibromodulin & 0.145 & -1.5 \\
M28671 & & ESTs, Highly similar to lg gamma -2B chain C region (GCB) & & \\
\hline
\end{tabular}

Gene expression regulation was examined by microarray analysis in the spleen, liver, thymus, and MLN of 17-week old male Wistar WU(CPB) rats after oral administration of LcS $(n=5)$ or a control solution $(n=5)$ during 8 successive days. The five most up- or down-regulated genes and genes showing an $F R \geq 1.5$ were selected.

Table 4.

Effects of oral LcS exposure on gene expression in rat liver.

\begin{tabular}{lllcc}
\hline GenBank & Symbol & Gene name & p-value & FR \\
\hline NM_012739 & Adra2a & Adrenergic, alpha 2A, receptor & 0.001 & 1.2 \\
NM_022618 & Akap6 & A kinase (PRKA) anchor protein 6 & 0.002 & -1.2 \\
NM_024000 & 1G5 & Vesicle-associated calmodulin-binding protein & 0.003 & -1.2 \\
NM_012515 & Bzrp & Benzodiazepin receptor (peripheral) & 0.004 & 1.1 \\
L10230 & Reg3a & Regenerating islet-derived 3 alpha & 0.004 & -1.1 \\
M64377 & Olr1361 & Olfactory receptor 1361 & 0.004 & -1.1 \\
BE100097 & & ESTs, Highly similar to A48024 glycosylphosphatidylinositol & 0.005 & -1.2 \\
NM_030847 & Emp3 & anchor class H biosynthesis protein [H.sapiens] & 0.005 & 1.2 \\
U29174 & Drg11 & Paired-like homeodomain trancription factor Drg11 & 0.006 & 1.2 \\
U23407 & Crabp2 & Cellular retinoic acid binding protein 2 & 0.013 & 1.2 \\
NM_022521 & Oat & Ornithine aminotransferase & 0.019 & -1.5 \\
NM_147215 & LOC259247 & alpha-2u globulin PGCL4 & 0.027 & -1.6 \\
J02589 & Ugt2b2 & Androsterone UDP-glucuronosyltransferase & 0.041 & -1.9 \\
NM_133295 & Ces3 & carboxylesterase 3 & 0.051 & -1.7 \\
NM_147137 & LOC257643 & cystatin SC & 0.057 & 1.6 \\
NM_024391 & Hsd17b2 & 17-beta hydroxysteroid dehydrogenase type 2 & 0.331 & 1.7 \\
\hline
\end{tabular}

For legend, see Table 3. 
Table 5.

Effects of oral LcS exposure on gene expression in rat thymus.

\begin{tabular}{lllll}
\hline GenBank & Symbol & Gene name & p-value & FR \\
\hline AF309558 & Sec14I2 & SEC14 (S. cerevisiae)-like 2 & 0.000 & -1.3 \\
NM_012646 & RT1-N1 & RT1 class Ib gene, H2-TL-like, grc region & 0.001 & 1.7 \\
AF084544 & Cspg2 & chondroitin sulfate proteoglycan 2 & 0.001 & -1.2 \\
AF015953 & Arntl & Aryl hydrocarbon receptor nuclear translocator-like & 0.002 & -1.2 \\
NM_031601 & Cacna1g & calcium channel, voltage-dependent, T type, alpha 1G & 0.002 & -1.2 \\
NM_012794 & Glycam1 & subunit & 0.003 & -1.4 \\
NM_017314 & Ubc & Ubiquitin C & 0.008 & 1.5 \\
Y17319 & CDK110 & Rattus norvegicus CDK110 mRNA & 0.010 & 1.7 \\
NM_012806 & Serk2 & Stress activated protein kinase beta & 0.012 & 1.2 \\
NM_021740 & Ptma & Prothymosin alpha & 0.016 & 1.5 \\
NM_017245 & Eef2 & Eukaryotic translation elongation factor 2 & 0.017 & 1.7 \\
AW917994 & & ESTs, Highly similar to TVMSM3 transforming protein myb & 0.061 & 1.6 \\
BG666505 & & (version 3) [M.musulus] & 0.107 & 1.7 \\
Al230498 & & ESTs, Highly similar to eukaryotic translation initiation factor & & 1.5 \\
NM_031841 & Scd2 & 4, gamma 2 [M.musulus] & Stearoyl-Coenzyme A desaturase 2 & 0.135 \\
L46593 & Sprr1a & small proline-rich protein 1A & 0.159 & 1.5
\end{tabular}

For legend, see Table 3.

\section{Table 6.}

Effects of oral LcS exposure on gene expression in rat MLN.

\begin{tabular}{lllcc}
\hline GenBank & Symbol & Gene name & p-value & FR \\
\hline AW916146 & & $\begin{array}{l}\text { ESTs, Highly similar to DNA-directed RNA polymerase II } \\
\text { largest subunit (RPB1) [M.musulus] }\end{array}$ & 0.000 & 1.1 \\
NM_022621 & NRP & Nucleolin-related protein NRP & 0.001 & -1.2 \\
BE099021 & & $\begin{array}{l}\text { ESTs, Moderately similar to T14738 hypothetical protein } \\
\text { DKFZp564A2416.1 (fragment) [H.sapiens] }\end{array}$ & 0.003 & -1.1 \\
Y07744 & Uae1 & UDP-N-acetylglucosamine-2-epimerase / & 0.003 & 1.1 \\
NM_013057 & F3 & N-acetylmannosamine kinase & 0.005 & 1.1 \\
NM_012718 & Andpro & Coagulation factor III (thromboplastin, tissue factor) & Androgen regulated 20 kDa protein & 0.008 \\
NM_019313 & Kcnn1 & Potassium intermediate/small conductance calcium-activated & 0.009 & -1.1 \\
AJ004858 & Sox11 & channel, subfamily N, member 1 & 0.009 \\
M92340 & II6st & SRY-box containing gene 11 & -1.1 \\
NM_012520 & Cat & Catalase & 0.010 & -1.2 \\
NM_022636 & Vax1 & Ventral anterior homeobox 1 & 0.012 & -1.6 \\
NM_012709 & Cyp2c12 & Cytochrom P450 15-beta gene & 0.016 & 1.1 \\
NM_019136 & Avpr2 & Arginine vasopressin receptor 2 & 0.044 & 1.1 \\
AF082160 & Grifin & Galectin-related inter-fiber protein & 0.094 & -2.0 \\
\hline
\end{tabular}

For legend, see Table 3. 


\section{Discussion}

We investigated the effects of oral administration of LcS on Th1 responses and development of autoimmunity in several experiments. In an adapted LLNA performed in $\mathrm{BALB} / \mathrm{c}$ mice, LcS was found to significantly reduce the proliferative response in draining lymph nodes after topical application of the Th1 cell-dependent antigen DNCB at the highest concentration used. This Th1 inhibition is inconsistent with the previously demonstrated stimulatory effect of LcS on Th1-mediated immune responses [35]. However, L. casei was shown to reduce allergic skin inflammation induced by topical application of 2,4-dinitrofluobenzene (DNFB) by decreasing the response of IFN- $\gamma$ producing cytotoxic $T$ cells and the Th1 driven $B$ cell response [7]. The cause was proposed to be either reduction of CD8+ $T$ cell priming or activation of regulatory $T(T r)$ cells through modulation of dendritic cell (DC) function by $L$. casei.

Probiotics have been suggested to affect DC maturation and functioning [55]. Since the development of $T$ cells is determined by the type of $D C$ and the extent of maturation [22,55-58], LAB could influence the development of Tr, Th1 or Th2 cells this way. Tr cells can inhibit either Th1 or Th2 activity or both and therefore be involved in the stimulation or inhibition of Th1 responses by LAB [59]. This would explain the fact that $L A B$ can exhibit both adjuvant activity on (Th1-mediated) immune defense mechanisms and anti-inflammatory effects preventing harmful allergic reactions. Anti-inflammatory effects of several LAB strains and prevention or suppression of Th1 associated pathologies like colitis were indeed reported before [15,60-62]. In accordance with this, enhancement of release of the Th1-inhibiting cytokine IL-10 [18,22,63-66], sometimes simultaneously with release of Th1-related cytokines $[23,26,61,67-69]$, by several $L A B$ has been reported. Other investigators established Th1 inhibition by a reduction in IL-12 and IFN-y by LAB $[44,60]$ or an increase of Th2 cytokines [68].

In contrast to the Th1 suppression that was detected in our modified LLNA, we found stimulation of Th1-mediated immunity in another model in which Th1 responses are predominant. Involvement of Th1 activity in EAE is indicated by induction of Th1-related cytokine production and autoreactive $T$ cells and a beneficial effect of stimulation of Th2mediated immunity [49]. In the EAE study in Lewis rats, both experimental groups lost weight at the same time that the first neurological signs of EAE appeared, but the LcS group recovered later from this weight loss than the control group. LcS significantly reduced the body weights, advanced the day of onset, prolonged the duration of EAE, and increased the cumulative clinical scores. The $\mathrm{CDI}$ and disease incidence were also increased by LcS. Altogether, these results indicate an aggravation of EAE by LcS, which is in line with the results of Maassen et al. [27] with the probiotic L. reuteri.

However, in the study of Maassen et al. [27] administration of L. casei 393 resulted in a reduction of the severity of EAE. The LAB strain-dependent stimulation or inhibition of EAE was explained by induction of specific cytokine profiles by the different strains, which was demonstrated in other experiments as well $[17,22,26,68]$. L. reuteri induced release of Th1 associated cytokines, whereas $L$. casei increased the production of the regulatory cytokines IL-10 and transforming growth factor (TGF)- $\beta$ [27]. This is consistent with the indications that $\operatorname{Tr}$ cells are involved in EAE [58,70-73]. They were mainly described to inhibit the onset and progression of EAE, possibly through IL-10 and TGF- $\beta$ secretion [73-77]. 
The study involving mitogen-induced cell proliferation and cytokine release measurements in the MLN of Wistar rats did not detect any inhibitory or stimulatory effects of LcS. The relative spleen weight was slightly but significantly increased as a result of oral LcS exposure, though, probably caused by increased spleen cell proliferation, as was reported for another LAB before [19]. In the spleen, liver, thymus and MLN of the same animals, microarray analysis was performed. The numbers of up- or down-regulated genes that were obtained were low in relation to the chance of false positive findings, indicating that no clear changes in gene expression induced by LcS administration were detected here. In addition, the most significantly regulated genes per organ did not indicate effects on cellular pathways or marked regulation of immune-related genes or transcription factors that are known to be involved in for example T cell differentiation [78].

The failure of the gene expression analysis to show overt effects of LcS could be the consequence of only subtle immunomodulation induced by LcS in this study. The LcS treatment was sufficient to cause a modest, though significant aggravation of EAE in Lewis rats, but mitogen responsiveness was not influenced by the same LcS treatment of Wistar rats. It was reported before that the immunomodulating effects of probiotics can depend on the immunological state of the host [11]. In addition, in a human trial performed in healthy immunocompetent volunteers no effects on diverse immune functions were established [79]. It would therefore be interesting to repeat the microarray experiment in an animal disease model in which T cells are triggered. From the absence of considerable changes in gene expression in this study it can be concluded that microarray analysis was not more sensitive or predictive than the immune function assays. An explanation could be that immunoregulation by LcS might not be detectable at the transcriptome level and could possibly affect cells at the protein level instead [80].

In conclusion, we detected immunomodulation by orally administered LCS, although the effects were generally modest. Depending on the assay used, inhibition or stimulation of Th1-mediated immune responses occurred, which confirms earlier indications that probiotics can skew the Th1/Th2 balance in both directions. Although Th1inhibiting properties of probiotics could be beneficial in some immune-related diseases, Th1 stimulation may have harmful consequences for the development of certain autoimmune disorders, as was demonstrated in the EAE model. Gene expression profiling had no more predictive potency or sensitivity than the immune function assays with respect to detection of immunomodulation. To gain further insight into immune regulation by probiotics, future experiments combining cytokine assays and gene expression analysis with disease models would be useful.

\section{Acknowledgements}

We thank the PMP department of the experimental animal laboratory for the biotechnical support. This research was supported by the Dutch Food and Consumer Product Safety Authority. 


\section{References}

1. Vijaya Kumar, S.G., Singh, S.K., Goyal, P., Dilbaghi, N., Mishra, D.N. (2005) Beneficial effects of probiotics and prebiotics on human health. Pharmazie 60, 163-171.

2. Gill, H.S., Guarner, F. (2004) Probiotics and human health: a clinical perspective. Postgrad Med J 80, 516526.

3. Noverr, M.C., Huffnagle, G.B. (2004) Does the microbiota regulate immune responses outside the gut? Trends Microbiol 12, 562-568.

4. de Vrese, M., Schrezenmeir, J. (2002) Probiotics and non-intestinal infectious conditions. Br J Nutr 88 Suppl 1, S59-S66.

5. Alvarez-Olmos, M.I., Oberhelman, R.A. (2001) Probiotic agents and infectious diseases: a modern perspective on a traditional therapy. Clin Infect Dis 32, 1567-1576.

6. Schiffrin, E.J., Rochat, F., Link-Amster, H., Aeschlimann, J.M., Donnet-Hughes, A. (1995) Immunomodulation of human blood cells following the ingestion of lactic acid bacteria. J Dairy Sci 78, 491-497.

7. Chapat, L., Chemin, K., Dubois, B., Bourdet-Sicard, R., Kaiserlian, D. (2004) Lactobacillus casei reduces CD8+ T cell-mediated skin inflammation. Eur J Immunol 34, 2520-2528.

8. Hart, A.L., Stagg, A.J., Kamm, M.A. (2003) Use of probiotics in the treatment of inflammatory bowel disease. J Clin Gastroenterol 36, 111-119.

9. Perdigon, G., Alvarez, S., Rachid, M., Aguero, G., Gobbato, N. (1995) Immune system stimulation by probiotics. J Dairy Sci 78, 1597-1606.

10. Marteau, P.R., De Vrese, M., Cellier, C.J., Schrezenmeir, J. (2001) Protection from gastrointestinal diseases with the use of probiotics. Am J Clin Nutr 73, 430S-436S.

11. Isolauri, E., Sutas, Y., Kankaanpaa, P., Arvilommi, H., Salminen, S. (2001) Probiotics: effects on immunity. Am J Clin Nutr 73, 444S-450S.

12. Kalliomaki, M., Isolauri, E. (2003) Role of intestinal flora in the development of allergy. Curr Opin Allergy Clin Immunol 3, 15-20.

13. Kalliomaki, M., Salminen, S., Poussa, T., Arvilommi, H., Isolauri, E. (2003) Probiotics and prevention of atopic disease: 4-year follow-up of a randomised placebo-controlled trial. Lancet 361, 1869-1871.

14. Sartor, R.B. (2005) Probiotic therapy of intestinal inflammation and infections. Curr Opin Gastroenterol 21, 44-50.

15. Drakes, M., Blanchard, T., Czinn, S. (2004) Bacterial probiotic modulation of dendritic cells. Infect Immun 72 , 3299-3309.

16. Cross, M.L., Ganner, A., Teilab, D., Fray, L.M. (2004) Patterns of cytokine induction by gram-positive and gram-negative probiotic bacteria. FEMS Immunol Med Microbiol 42, 173-180.

17. Morita, H., He, F., Fuse, T., Ouwehand, A.C., Hashimoto, H., Hosoda, M., Mizumachi, K., Kurisaki, J. (2002) Cytokine production by the murine macrophage cell line J774.1 after exposure to Lactobacilli. Biosci Biotechnol Biochem 66, 1963-1966.

18. Miettinen, M., Vuopio-Varkila, J., Varkila, K. (1996) Production of human tumor necrosis factor alpha, interleukin-6, and interleukin-10 is induced by lactic acid bacteria. Infect Immun 64, 5403-5405.

19. Gill, H.S., Rutherfurd, K.J., Prasad, J., Gopal, P.K. (2000) Enhancement of natural and acquired immunity by Lactobacillus rhamnosus (HN001), Lactobacillus acidophilus (HN017) and Bifidobacterium lactis (HN019). $\mathrm{Br}$ J Nutr 83, 167-176.

20. Pochard, P., Gosset, P., Grangette, C., Andre, C., Tonnel, A.B., Pestel, J., Mercenier, A. (2002) Lactic acid bacteria inhibit $\mathrm{TH} 2$ cytokine production by mononuclear cells from allergic patients. J Allergy Clin Immunol 110, 617-623.

21. Mohamadzadeh, M., Olson, S., Kalina, W.V., Ruthel, G., Demmin, G.L., Warfield, K.L., Bavari, S., Klaenhammer, T.R. (2005) Lactobacilli activate human dendritic cells that skew T cells toward T helper 1 polarization. Proc Natl Acad Sci U S A 102, 2880-2885.

22. Christensen, H.R., Frokiaer, H., Pestka, J.J. (2002) Lactobacilli differentially modulate expression of cytokines and maturation surface markers in murine dendritic cells. J Immunol 168, 171-178.

23. Hessle, C., Hanson, L.A., Wold, A.E. (1999) Lactobacilli from human gastrointestinal mucosa are strong stimulators of IL-12 production. Clin Exp Immunol 116, 276-282.

24. Murosaki, S., Yamamoto, Y., Ito, K., Inokuchi, T., Kusaka, H., Ikeda, H., Yoshikai, Y. (1998) Heat-killed Lactobacillus plantarum L-137 suppresses naturally fed antigen-specific IgE production by stimulation of IL12 production in mice. J Allergy Clin Immunol 102, 57-64.

25. Shida, K., Takahashi, R., Iwadate, E., Takamizawa, K., Yasui, H., Sato, T., Habu, S., Hachimura, S., Kaminogawa, S. (2002) Lactobacillus casei strain Shirota suppresses serum immunoglobulin E and 
immunoglobulin G1 responses and systemic anaphylaxis in a food allergy model. Clin Exp Allergy 32, 563570.

26. Fujiwara, D., Inoue, S., Wakabayashi, H., Fujii, T. (2004) The anti-allergic effects of lactic acid bacteria are strain dependent and mediated by effects on both Th1/Th2 cytokine expression and balance. Int Arch Allergy Immunol 135, 205-215.

27. Maassen, C.B., Van Holten, J.C., Balk, F., Heijne den Bak-Glashouwer MJ, Leer, R., Laman, J.D., Boersma, W.J., Claassen, E. (1998) Orally administered Lactobacillus strains differentially affect the direction and efficacy of the immune response. Vet Q 20 Suppl 3, S81-S83.

28. Erickson, K.L., Hubbard, N.E. (2000) Probiotic immunomodulation in health and disease. J Nutr 130, 403S409s.

29. Nagao, F., Nakayama, M., Muto, T., Okumura, K. (2000) Effects of a fermented milk drink containing Lactobacillus casei strain Shirota on the immune system in healthy human subjects. Biosci Biotechnol Biochem 64, 2706-2708.

30. Takagi, A., Matsuzaki, T., Sato, M., Nomoto, K., Morotomi, M., Yokokura, T. (2001) Enhancement of natural killer cytotoxicity delayed murine carcinogenesis by a probiotic microorganism. Carcinogenesis 22, 599-605.

31. Hori, T., Kiyoshima, J., Yasui, H. (2003) Effect of an oral administration of Lactobacillus casei strain Shirota on the natural killer activity of blood mononuclear cells in aged mice. Biosci Biotechnol Biochem 67, 420-422.

32. Matsuzaki, T., Chin, J. (2000) Modulating immune responses with probiotic bacteria. Immunol Cell Biol 78, 67-73.

33. Yasui, H., Kiyoshima, J., Hori, T. (2004) Reduction of influenza virus titer and protection against influenza virus infection in infant mice fed Lactobacillus casei Shirota. Clin Diagn Lab Immunol 11, 675-679.

34. Matsuzaki, T., Saito, M., Usuku, K., Nose, H., Izumo, S., Arimura, K., Osame, M. (2005) A prospective uncontrolled trial of fermented milk drink containing viable Lactobacillus casei strain Shirota in the treatment of HTLV-1 associated myelopathy/tropical spastic paraparesis. J Neurol Sci 237, 75-81.

35. Yasui, H., Shida, K., Matsuzaki, T., Yokokura, T. (1999) Immunomodulatory function of lactic acid bacteria. Antonie Van Leeuwenhoek 76, 383-389.

36. de Waard, R., Garssen, J., Bokken, G.C., Vos, J.G. (2002) Antagonistic activity of Lactobacillus casei strain Shirota against gastrointestinal Listeria monocytogenes infection in rats. Int J Food Microbiol 73, 93-100.

37. Matsuzaki, T., Yamazaki, R., Hashimoto, S., Yokokura, T. (1998) The effect of oral feeding of Lactobacillus casei strain Shirota on immunoglobulin E production in mice. J Dairy Sci 81, 48-53.

38. Shida, K., Makino, K., Morishita, A., Takamizawa, K., Hachimura, S., Ametani, A., Sato, T., Kumagai, Y., Habu, S., Kaminogawa, S. (1998) Lactobacillus casei inhibits antigen-induced IgE secretion through regulation of cytokine production in murine splenocyte cultures. Int Arch Allergy Immunol 115, 278-287.

39. Matsuzaki, T. (1998) Immunomodulation by treatment with Lactobacillus casei strain Shirota. Int J Food Microbiol 41, 133-140.

40. Kato, I., Tanaka, K., Yokokura, T. (1999) Lactic acid bacterium potently induces the production of interleukin12 and interferon-gamma by mouse splenocytes. Int J Immunopharmacol 21, 121-131.

41. Kato, I., Endo-Tanaka, K., Yokokura, T. (1998) Suppressive effects of the oral administration of Lactobacillus casei on type II collagen-induced arthritis in DBA/1 mice. Life Sci 63, 635-644.

42. Matsuzaki, T., Nagata, Y., Kado, S., Uchida, K., Kato, I., Hashimoto, S., Yokokura, T. (1997) Prevention of onset in an insulin-dependent diabetes mellitus model, NOD mice, by oral feeding of Lactobacillus casei. APMIS 105, 643-649.

43. Matsuzaki, T., Nagata, Y., Kado, S., Uchida, K., Hashimoto, S., Yokokura, T. (1997) Effect of oral administration of Lactobacillus casei on alloxan-induced diabetes in mice. APMIS 105, 637-642.

44. Matsuzaki, T., Yamazaki, R., Hashimoto, S., Yokokura, T. (1997) Antidiabetic effects of an oral administration of Lactobacillus casei in a non-insulin-dependent diabetes mellitus (NIDDM) model using KK-Ay mice. Endocr J 44, 357-365.

45. Baharav, E., Mor, F., Halpern, M., Weinberger, A. (2004) Lactobacillus GG bacteria ameliorate arthritis in Lewis rats. J Nutr 134, 1964-1969.

46. Calcinaro, F., Dionisi, S., Marinaro, M., Candeloro, P., Bonato, V., Marzotti, S., Corneli, R.B., Ferretti, E., Gulino, A., Grasso, F., De Simone, C., Di Mario, U., Falorni, A., Boirivant, M., Dotta, F. (2005) Oral probiotic administration induces interleukin-10 production and prevents spontaneous autoimmune diabetes in the nonobese diabetic mouse. Diabetologia 48, 1565-1575.

47. Kimber, I., Dearman, R.J., Basketter, D.A., Ryan, C.A., Gerberick, G.F. (2002) The local lymph node assay: past, present and future. Contact Dermatitis 47, 315-328.

48. Van den Berg, F.A., Baken, K.A., Vermeulen, J.P., Gremmer, E.R., Van Steeg, H., Van Loveren, H. (2005) Use of the local lymph node assay in assessment of immune function. Toxicology 211, 107-114.

49. Lassmann, H., Ransohoff, R.M. (2004) The CD4-Th1 model for multiple sclerosis: a critical [correction of crucial] re-appraisal. Trends Immunol 25, 132-137. 
50. Steiner, G., Suter, L., Boess, F., Gasser, R., De Vera, M.C., Albertini, S., Ruepp, S. (2004) Discriminating different classes of toxicants by transcript profiling. Environ Health Perspect 112, 1236-1248.

51. de Longueville, F., Bertholet, V., Remacle, J. (2004) DNA microarrays as a tool in toxicogenomics. Comb Chem High Throughput Screen 7, 207-211.

52. Waters, M.D., Fostel, J.M. (2004) Toxicogenomics and systems toxicology: aims and prospects. Nat Rev Genet 5, 936-948.

53. Van de Peppel, J., Kemmeren, P., Van Bakel, H., Radonjic, M., Van Leenen, D., Holstege, F.C. (2003) Monitoring global messenger RNA changes in externally controlled microarray experiments. EMBO Rep 4, 387-393.

54. Pennings, J.L.A., Heisterkamp, S.H. (2004) Normal Probability Plots for Quality Assessment of Microarray Experiments. Abstract. Proceedings of the 12th International Conference on Intelligent Systems for Molecular Biology and the 3rd European Conference on Computational Biology 143-

55. Stagg, A.J., Hart, A.L., Knight, S.C., Kamm, M.A. (2004) Microbial-gut interactions in health and disease. Interactions between dendritic cells and bacteria in the regulation of intestinal immunity. Best Pract Res Clin Gastroenterol 18, 255-270.

56. McGuirk, P., Mills, K.H. (2002) Pathogen-specific regulatory T cells provoke a shift in the Th1/Th2 paradigm in immunity to infectious diseases. Trends Immunol 23, 450-455.

57. Kalinski, P., Hilkens, C.M., Wierenga, E.A., Kapsenberg, M.L. (1999) T-cell priming by type-1 and type-2 polarized dendritic cells: the concept of a third signal. Immunol Today 20, 561-567.

58. Maloy, K.J., Powrie, F. (2001) Regulatory T cells in the control of immune pathology. Nat Immunol 2, 816822.

59. Kidd, P. (2003) Th1/Th2 balance: the hypothesis, its limitations, and implications for health and disease. Altern Med Rev 8, 223-246.

60. Schultz, M., Veltkamp, C., Dieleman, L.A., Grenther, W.B., Wyrick, P.B., Tonkonogy, S.L., Sartor, R.B. (2002) Lactobacillus plantarum 299V in the treatment and prevention of spontaneous colitis in interleukin-10deficient mice. Inflamm Bowel Dis 8, 71-80.

61. von der Weid, T., Bulliard, C., Schiffrin, E.J. (2001) Induction by a lactic acid bacterium of a population of CD4(+) T cells with low proliferative capacity that produce transforming growth factor beta and interleukin- 10 . Clin Diagn Lab Immunol 8, 695-701.

62. Madsen, K.L., Doyle, J.S., Jewell, L.D., Tavernini, M.M., Fedorak, R.N. (1999) Lactobacillus species prevents colitis in interleukin 10 gene-deficient mice. Gastroenterology 116, 1107-1114.

63. Hart, A.L., Lammers, K., Brigidi, P., Vitali, B., Rizzello, F., Gionchetti, P., Campieri, M., Kamm, M.A., Knight, S.C., Stagg, A.J. (2004) Modulation of human dendritic cell phenotype and function by probiotic bacteria. Gut 53, 1602-1609.

64. Smits, H.H., Engering, A., Van der Kleij, D., De Jong, E.C., Schipper, K., Van Capel, T.M., Zaat, B.A., Yazdanbakhsh, M., Wierenga, E.A., Van Kooyk, Y., Kapsenberg, M.L. (2005) Selective probiotic bacteria induce IL-10-producing regulatory $T$ cells in vitro by modulating dendritic cell function through dendritic cellspecific intercellular adhesion molecule 3-grabbing nonintegrin. J Allergy Clin Immunol 115, 1260-1267.

65. Borruel, N., Casellas, F., Antolin, M., Llopis, M., Carol, M., Espiin, E., Naval, J., Guarner, F., Malagelada, J.R. (2003) Effects of nonpathogenic bacteria on cytokine secretion by human intestinal mucosa. Am J Gastroenterol 98, 865-870.

66. Pessi, T., Sutas, Y., Hurme, M., Isolauri, E. (2000) Interleukin-10 generation in atopic children following oral Lactobacillus rhamnosus GG. Clin Exp Allergy 30, 1804-1808.

67. Cross, M.L., Mortensen, R.R., Kudsk, J., Gill, H.S. (2002) Dietary intake of Lactobacillus rhamnosus HNOO1 enhances production of both Th1 and Th2 cytokines in antigen-primed mice. Med Microbiol Immunol (Berl) 191, 49-53.

68. Perdigon, G., Maldonado, G.C., Valdez, J.C., Medici, M. (2002) Interaction of lactic acid bacteria with the gut immune system. Eur J Clin Nutr 56 Suppl 4, S21-S26.

69. Shimosato, T., Kitazawa, H., Katoh, S., Tohno, M., Iliev, I.D., Nagasawa, C., Kimura, T., Kawai, Y., Saito, T. (2005) Augmentation of $\mathrm{T}(\mathrm{H})-1$ type response by immunoactive AT oligonucleotide from lactic acid bacteria via Toll-like receptor 9 signaling. Biochem Biophys Res Commun 326, 782-787.

70. Leonard, J.P., Waldburger, K.E., Goldman, S.J. (1995) Prevention of experimental autoimmune encephalomyelitis by antibodies against interleukin 12. J Exp Med 181, 381-386.

71. Trembleau, S., Germann, T., Gately, M.K., Adorini, L. (1995) The role of IL-12 in the induction of organspecific autoimmune diseases. Immunol Today 16, 383-386.

72. Weiner, H.L. (2001) Oral tolerance: immune mechanisms and the generation of Th3-type TGF-beta-secreting regulatory cells. Microbes Infect 3, 947-954. 
73. Behi, M.E., Dubucquoi, S., Lefranc, D., Zephir, H., De Seze, J., Vermersch, P., Prin, L. (2005) New insights into cell responses involved in experimental autoimmune encephalomyelitis and multiple sclerosis. Immunol Lett 96, 11-26.

74. Lutton, J.D., Winston, R., Rodman, T.C. (2004) Multiple sclerosis: etiological mechanisms and future directions. Exp Biol Med (Maywood) 229, 12-20.

75. Zhang, X., Koldzic, D.N., Izikson, L., Reddy, J., Nazareno, R.F., Sakaguchi, S., Kuchroo, V.K., Weiner, H.L. (2004) IL-10 is involved in the suppression of experimental autoimmune encephalomyelitis by CD25+CD4+ regulatory T cells. Int Immunol 16, 249-256.

76. Furtado, G.C., Olivares-Villagomez, D., Curotto de Lafaille, M.A., Wensky, A.K., Latkowski, J.A., Lafaille, J.J. (2001) Regulatory T cells in spontaneous autoimmune encephalomyelitis. Immunol Rev 182, 122-134.

77. Kohm, A.P., Carpentier, P.A., Anger, H.A., Miller, S.D. (2002) Cutting edge: CD4+CD25+ regulatory T cells suppress antigen-specific autoreactive immune responses and central nervous system inflammation during active experimental autoimmune encephalomyelitis. J Immunol 169, 4712-4716.

78. Neurath, M.F., Finotto, S., Glimcher, L.H. (2002) The role of Th1/Th2 polarization in mucosal immunity. Nat Med 8, 567-573.

79. Spanhaak, S., Havenaar, R., Schaafsma, G. (1998) The effect of consumption of milk fermented by Lactobacillus casei strain Shirota on the intestinal microflora and immune parameters in humans. Eur $\mathrm{J}$ Clin Nutr 52, 899-907.

80. Schmidt, C.W. (2002) Toxicogenomics: an emerging discipline. Environ Health Perspect 110, A750-A755. 

Summary and general discussion 


\section{Main findings}

Microarray analysis is used for simultaneous measurement of expression of thousands of genes in a given sample and as such extends and deepens our understanding of biological processes. Application of this technique to study adverse effects of xenobiotics is referred to as toxicogenomics. Adverse effects of interactions of substances with the immune system have traditionally been assessed by evaluation of changes in organ weights, histopathology of immunological tissues, and various immune function tests. Gene expression profiling is a relatively new approach to study immunotoxicity. Examples of immunotoxicogenomics studies that have appeared in the literature (Chapter 1 and [1]) show that microarray analysis is able to detect known and novel effects of a wide range of immunomodulating agents. They also show, however, the impact of dose, duration of exposure, and number of genes examined on the outcome of microarray analysis and illustrate the importance of anchoring gene expression profiles to pathological and functional endpoints for correct interpretation of results. Besides the elucidation of mechanisms of action, toxicogenomics is also applied to predict consequences of exposing biological systems to toxic agents. Successful attempts to classify compounds using signature gene expression profiles have been reported outside the area of immunotoxicology. Databases containing expression profiles can facilitate the application of toxicogenomics. Platforms and methodologies for gene expression profiling may vary, however, hampering data compiling across different laboratories. Therefore, attention is paid to standardization of the generation, reporting, and management of microarray data. The application of toxicogenomics in evaluation of immunotoxicity is thus not without challenges. It already contributes to the understanding of immunotoxic processes and the development of in vitro screening assays, though, and is therefore expected to be of value for mechanistic insight into immunotoxicity and for hazard identification of existing and novel compounds. We tested these assumptions by performing a range of experiments evaluating the applicability of gene expression profiling for identification of immunotoxic events. The main findings of these studies are summarized in Box I and described below. 


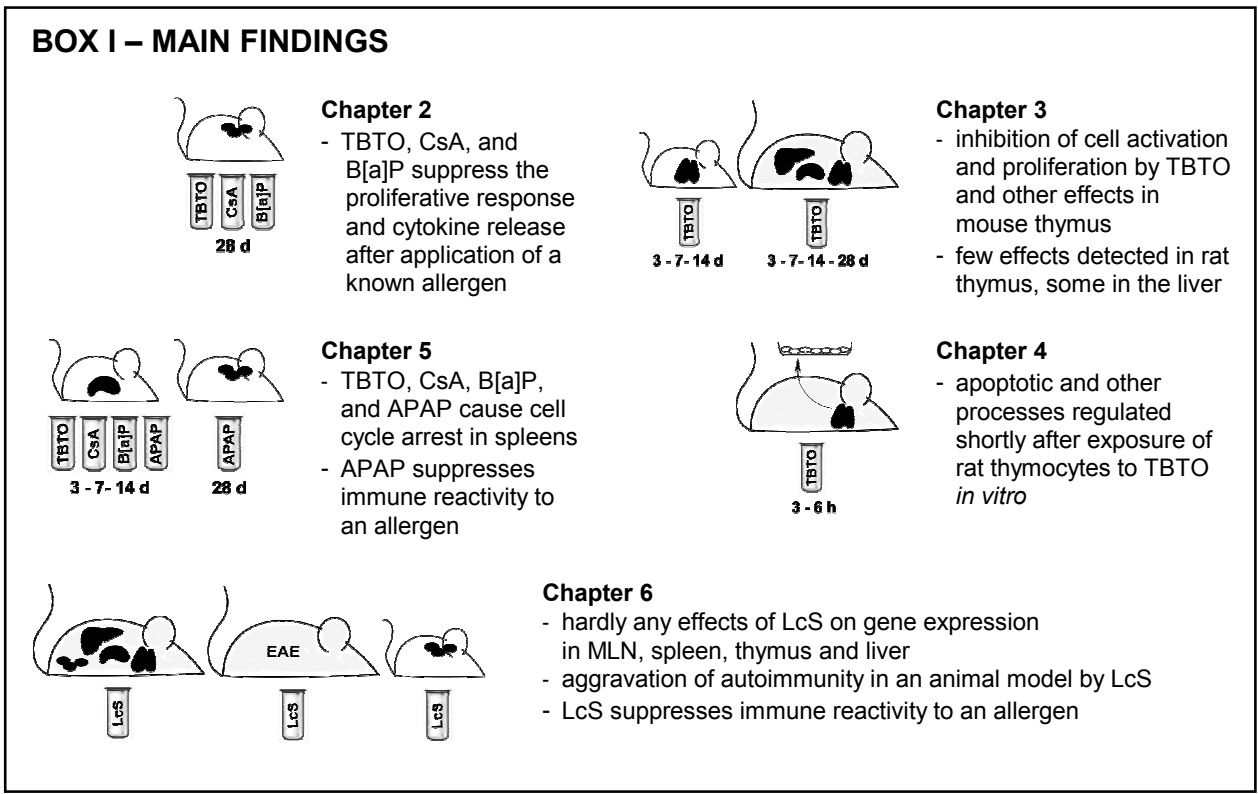

\section{Application of the LLNA as an immune function assay}

The murine Local Lymph Node Assay (LLNA) was originally designed as a screening system for allergenicity of chemicals, in which the proliferative response of draining lymphocytes to cutaneous application of a contact sensitizer indicates the sensitizing capacity. In Chapter 2, we described an alternative use of this assay. Prior to performance of an adapted LLNA with a well known sensitizer, the mice were fed the immunosuppressive compounds bis(tri- $n$-butyltin)oxide (TBTO), cyclosporin A (CsA), or benzo[a]pyrene $(\mathrm{B}[\mathrm{a}] \mathrm{P})$ during 28 days, and the effect on lymphocyte proliferation was evaluated to assess effects on immune reactivity. In addition, release of Th1- and Th2related cytokines by the LN cells was monitored, so as to gain insight into effects of the compounds administered on the Th1/Th2 balance. Both LN cell proliferation and IL-4 and IFN-y release were suppressed by all compounds, indicating immunosuppression. Comparison of the levels of both cytokines showed that TBTO caused a shift towards Th2and $\mathrm{CsA}$ and $\mathrm{B}[\mathrm{a}] \mathrm{P}$ towards Th1-dependent immunity, which may be of relevance regarding modulation of allergic or autoimmune responses. It was concluded that the immune function assay adapted from the LLNA is applicable for demonstration of immunosuppressive effects of orally administered toxicants, especially at highly effective allergen dose levels. The results of the study reported in Chapter 2 also served to demonstrate and mutually compare the level of immunosuppression by the immunotoxicants that were studied by gene expression profiling, since the same dose levels were used in subsequent experiments that are described in Chapter $\mathbf{3}$ and Chapter 5. 


\section{Detection of immunotoxic effects by gene expression profiling}

In order to establish the ability of gene expression profiling to reveal immunotoxic effects and to generate mechanistic information, transcriptional changes after administration of the immunosuppressive dose level of TBTO to mice for 3,7 , and 14 days were first examined in the thymus, which is the primary target organ for this compound. TBTO exposure resulted in thymic atrophy, and microarray analysis revealed reduced expression of cell surface determinants and receptors and inhibition of cell cycle-related processes, pointing to interference with $\mathrm{T}$ cell activation and inhibition of proliferation as a primary mechanism of action of TBTO. Some processes found to be affected by TBTO in this study (e.g. protein biosynthesis) were reported to be interrupted by TBTO previously, while other had not been reported before. An example of the latter was stimulation of mitochondrial functioning and substrate metabolism, which may be a compensatory response to mitochondrial damage or to stress. Several nuclear receptors that may be involved in the effects on lipid metabolism were identified.

A similar experiment was performed in rats, where a somewhat lower dose that nevertheless induced thymus involution hardly caused gene expression changes in the thymus as well as the spleen. In the liver of these animals down-regulation of lipid synthesis was detected. The differences between the results of the two experiments, which were the subject of Chapter 3, were ascribed to dose or interspecies differences.

\section{Detection of immunotoxic effects by gene expression profiling in vitro}

Since hardly any gene expression changes induced by TBTO were detected in rat thymuses, thymocytes were exposed to (non)cytotoxic doses of TBTO directly in the in vitro approach described in Chapter 4. Several clues to mechanisms of action were obtained by this approach. Regulation of lipid metabolism by TBTO appeared at a low dose that did not yet result in disruption of cell functioning, and higher doses caused regulation of apoptotic processes, even before this could be observed phenotypically. Indications were obtained that effects on apoptosis may be mediated by modulation of glucocorticoid signaling. The highest dose level tested additionally repressed mitochondrial functioning and immune cell activation. Several results corresponded to previous findings, but in contrast to the conclusion of Chapter 3 and of previous in vivo and in vitro studies that inhibition of cell proliferation was the primary mechanisms of action of TBTO, apoptosis appeared to mediate TBTO's toxic effects in our in vitro study. The discrepancy between these results is most likely a result of differences in the experimental setup (in vitro vs. in vivo, duration of exposure to TBTO).

\section{Detection of overlapping gene expression profiles of immunotoxicants}

After the observation that immunotoxic effects of TBTO could be demonstrated by microarray analysis in its target organ (Chapter $\mathbf{3}$ and Chapter 4 ), a next step was to find overlapping transcriptional effects of a range of immunosuppressive compounds that may eventually be of use for development of screening systems for identification of immunotoxic effects of chemicals. In Chapter $\mathbf{5}$ it is described how we assessed gene 
expression profiles in the spleen of mice exposed to TBTO, CsA, B[a]P, and acetaminophen (APAP). Several compound-specific and overlapping effects were detected. TBTO for instance interrupted cellular respiration, and CsA and B[a]P inhibited immunological processes. All compounds induced xenobiotic metabolism, and the most significantly affected process for all toxicants was cell division (as was detected for TBTO in the thymus as well, see Chapter 3 ). Highly proliferating immune cells will be particularly sensitive to the latter effect, and evaluation of cell proliferation thus remains a valuable tool to assess immunosuppression. APAP is not an immunotoxic model compound, but since some evidence on immunomodulation by APAP has been published, the consequences of exposure to this compound were compared to those of the other toxicants. Since APAP exposure caused transcriptional effects overlapping with those of the model compounds, resulted in decreased spleen size in absence of reduction of body weight gain, and moreover caused a level of suppression of immune reactivity in the immune function assay adapted from the LLNA comparable to the other compounds (Chapter 2), it was concluded that APAP possesses immunosuppressive properties at the dose levels used which appear to be mediated by cell cycle arrest.

\section{Evaluation of immunomodulating effects of a probiotic bacterium}

To confirm and further investigate modulation of Th1 responses and development of autoimmune disease by Lactobacillus casei Shirota (LCS), we examined the immunomodulatory capacity of this probiotic bacterium in several assays, among which was gene expression profiling as a new approach. Chapter 6 deals with the results of these studies. The nature of the immunomodulation caused by LcS was determined by the model used. No modulation was detected in mitogen responsiveness and cytokine release assays. LcS inhibited the Th1-mediated immune response in the LLNA applied as an immune function assay, but aggravated Experimental Autoimmune Encephalomyelitis (EAE). These varying effects on Th1 responses indicate that beneficial as well as harmful effects on immune-related disorders may occur after LcS consumption. Gene expression profiles in mesenteric lymph nodes, spleen, thymus, and liver did not reflect the immunomodulation by LCS. The reason for this could be that the immunomodulating effects of the probiotic were only subtle, or, as effects were found in the autoimmunity model, T cell triggering may be a prerequisite for induction of effects by LcS. Alternatively, probiotics may exert their immunomodulating effects at the protein instead of the gene expression level. 


\section{General discussion}

The research described in this thesis focused at identification of immunotoxicity by means of gene expression profiling. The occurrence of functional effects of all investigated compounds on immune responsiveness was demonstrated using an immune function assay that was adapted from the LLNA. The usefulness of this assay for indicating immunosuppression was demonstrated in several chapters.

The results of the microarray studies performed using the immunomodulating compounds illustrate several issues raised by previous toxicogenomics studies. The effect of duration of exposure on gene expression profiles was for instance demonstrated in the in vitro study, in which induction of apoptosis by TBTO appeared to precede inhibition of cell proliferation, since the latter was the main finding after longer exposure periods in previous in vitro studies and our own in vivo study. The impact of the dose level on microarray results was illustrated by the experiments in mice and rats. Administration of a high dose of TBTO to mice resulted in significant regulation of gene expression whereas absence of overt gene expression changes was found in rat thymus after exposure to a somewhat lower dose. The impression that high dose levels are needed to induce differential gene expression was supported by the experiments in murine spleen, where even maximum tolerated dose levels of $\mathrm{Cs} A$ and $\mathrm{B}[\mathrm{a}] \mathrm{P}$ did not induce significant regulation of individual genes. Regulation of cellular pathways relevant for their mechanism of action was however detected by group wise Gene Ontology analysis, which proved to be a powerful tool for identification of relatively subtle transcriptional effects.

Our results do not support the assumption that microarray analysis, at least when using the microarray platforms applied in our studies, is able to demonstrate toxic effects at lower dose levels than traditional methods to study toxicity. Although the differences in results of microarray analyses in murine and rat thymuses might reflect differences in species instead of or in addition to dose, thymus atrophy, which is a sensitive marker of immunotoxicity, was observed in rats whereas regulation of gene transcription was relatively absent. LcS exposure also failed to induce significant effects on gene expression although immunomodulation was detected in other assays. Gene expression profiling is also suggested to be more sensitive than other test methods in terms of duration of exposure. Some effects of TBTO, CsA, B[a]P, and APAP on gene expression indeed appeared before effects on organ weight or histology were observed. In the in vitro experiment, we clearly detected induction of apoptosis by TBTO before this could be detected phenotypically. However, pro- as well as anti-apoptotic processes were stimulated by TBTO. Hence, changes in expression of genes mediating a certain process do not necessarily all point to the same direction. In addition, often not all genes taking part in a certain pathway are regulated. Moreover, compounds can exert effects that are not detected at the transcriptional level. TBTO is for example known to affect cell membranes, the cytoskeleton, and protein phosphorylation, and effects of probiotic bacteria on immune cells may also take place at the protein level. Finally, it is possible that induction of an immune response is required for probiotics or other immunomodulators to exert their effects, rendering immune function assays more suitable for detection of effects. Overall, gene expression profiling may not always provide decisive answers on the occurrence of (immuno)toxic events, but does have the capacity to reveal effects at early time points. 
An aspect that may complicate the interpretation of microarray results is that changes in cell populations may affect gene expression profiles that are revealed by microarray analysis. TBTO is for instance known to be particularly toxic for rapidly dividing cortical thymocytes. At a certain time point after the start of the exposure, these cells (and their transcriptomes) may have been removed from the cell population in the thymus in vivo, whereas they might be cleared less efficiently in vitro. In our in vitro experiment, the simultaneous detection of pro- and anti-apoptotic processes may be explained by the occurrence of different events in different subpopulations of cells. When assessing effects in the spleen, influx of cells via the blood (possibly as a result of xenobiotic exposure) may influence gene expression profiles. In addition, different compounds may affect different cell types in this organ, which may complicate comparison of effects of xenobiotics. For evaluation of mechanisms of action, comparison of gene expression changes with effects detected by other test methods is therefore important. When compounds are screened for immunotoxic effects, however, most important is that effects of the toxicants are eventually represented in the overall gene expression profile. In all cases mentioned above we were able to uncover effects of the compounds through assessment of gene expression changes.

Toxicogenomics assesses genome wide changes in gene expression and is therefore expected to provide insight into mechanisms of actions of xenobiotics. We performed in vivo and in vitro studies to elucidate the mechanisms of action of TBTO. Several known effects of TBTO, such as interference with mitochondrial functioning and protein synthesis, were detected by microarray analysis. Whether TBTO primarily causes inhibition of cell proliferation or induction of apoptosis has been a matter of debate for a long time. Whereas we detected the former in thymus and spleen in our in vivo experiments in mice, the latter was the main effect of TBTO in rat thymocytes in vitro. Although this discrepancy might reflect a species difference, inhibition of cell proliferation by TBTO has previously been detected in rats as well. We therefore hypothesize that induction of apoptosis is an effect of TBTO that precedes inhibition of proliferation in time. Additional experiments examining effects in vivo at earlier time points and in vitro in murine thymocytes need to be performed to confirm this theory. Other new mechanistic information generated by the microarray analyses was for instance the reduction of expression of cell surface determinants, the possible involvement of glucocorticoid receptor signaling in apoptotic effects of TBTO, and the regulation of lipid metabolism through nuclear receptors. These effects and their functional implications should also be investigated in future experiments. APAP was another compound for which the immunotoxicogenomics approach generated new insights into its mechanism of action. Indications of immunomodulating properties that had appeared in the literature and were detected by the immune function assay adapted from the LLNA and by reduction of spleen size in absence of general toxicity, were confirmed by identification of overlap of the gene expression profile of APAP with that of model immunotoxicants. Since the immune system may possess reserve capacity and compensatory mechanisms and the extent of a change in gene expression does not necessarily correspond to a functional effect of similar size, the clinical implications of these findings should be further investigated.

Another promise of toxicogenomics is that it will contribute to the development of screening assays by identifying signature gene expression profiles for specific classes of compounds. We tested this assumption by comparing gene expression profiles of several 
immunotoxicants. Induction of cell cycle arrest appeared to be a shared effect (even though the mechanism by which this was accomplished may differ between the compounds), and several genes were identified that might be of use as biomarkers for immunosuppression. This experiment thus illustrates the usefulness of evaluating effects of xenobiotics on cell proliferation, which is part of current immunotoxicity testing. Obviously, the specificity and predictivity of inhibition of cell proliferation for immunotoxicity in general should be confirmed by testing a larger range of compounds. Patterson et al. [2] examined gene expression changes induced by the prototype immunosuppressive agents CsA, 2,3,7,8-tetrachlorodibenzo- $p$-dioxin (TCDD), cyclophosphamide, and dexamethason in murine thymus (that involuted after toxicant exposure) and spleen. Preliminary data showed that although most transcriptional effects were compound-specific, some genes were regulated by all compounds. These genes were mainly involved in apoptosis, antigen presentation and processing, and immune cell activation and proliferation. No overlap in individual genes was found between this study and our study, but this may be due to the limited amount of genes that was published by Patterson et al. and that was present on their microarray [2]. Since in this study as well as our own study only immunosuppressive compounds were included, the value of cell proliferation as a biomarker in other areas of immunotoxicology such as sensitization and autoimmunity should still be investigated. Our microarray study also showed that the spleen is a suitable organ for detection of immunosuppression by gene expression profiling. Since effects in this organ are presumably reflected in peripheral lymphocytes that can easily be obtained from blood, this is a valuable finding with respect to development of screening assays. Future evaluation of gene expression profiles in human cells will elucidate the relevance of our findings for the human situation. Since effects of xenobiotics in vitro may differ intrinsically from effects in vivo, and in vitro systems often do not represent the diversity of cell types that is present in the immune system, the relevance of results obtained in vitro for the in vivo situation and the possibility to use in vitro assays for prediction of immunotoxic effects should first be further explored.

Several of the issues mentioned above were also discussed in a workshop addressing the application of toxicogenomics in immunotoxicity screening and in a recent review on this topic $[1,3]$. 


\section{Conclusion}

From the results presented in this thesis it can be concluded that examination of immunotoxic effects of compounds by means of gene expression profiling should involve several dose levels and exposure periods. Immunotoxicogenomics appears not to be more sensitive than traditional methods to study immunotoxicity in terms of dose levels needed to reveal effects, but is able to demonstrate immunosuppressive effects at an early time point. Inhibition of cell proliferation was found to be a common effect of a set of immunosuppressive model compounds. Since additional compounds need to be evaluated and in vitro test systems for (pre-)screening for immunotoxicity need to be further elaborated, toxicogenomics may not yet be able to replace the current methods for assessment of immunotoxicity. It is a valuable tool for broadening the mechanistic understanding of immunotoxicity, though, and offers opportunities for hazard identification of existing and novel compounds.

\section{References}

1. Burns-Naas, L.A., Dearman, R.J., Germolec, D.R., Kaminski, N.E., Kimber, I., Ladics, G.S., Luebke, R.W., Pfau, J.C., Pruett, S.B. (2006) 'Omics' technologies and the immune system. Tox Mech Methods 16, 101119.

2. Patterson, R.M., Germolec, D.R. (2006) Gene expression alterations in immune system pathways following exposure to immunosuppressive chemicals. Ann N Y Acad Sci 1076, 718-727.

3. Luebke, R.W., Holsapple, M.P., Ladics, G.S., Luster, M.I., Selgrade, M., Smialowicz, R.J., Woolhiser, M.R., Germolec, D.R. (2006) Immunotoxicogenomics: the potential of genomics technology in the immunotoxicity risk assessment process. Toxicol Sci 94, 22-27. 



\section{Samenvatting en discussie}




\section{Samenvatting}

Microarray-analyse wordt gebruikt om de activiteit (ofwel transcriptie of expressie) van vele duizenden genen tegelijk in onderzoeksmateriaal te meten, en bewerkstelligt op deze manier verdieping en verbreding van de kennis omtrent biologische processen. De toepassing van deze techniek voor het bestuderen van ongewenste effecten van lichaamsvreemde stoffen (xenobiotica) in blootgestelde organismen of cellen wordt ook wel 'toxicogenomics' genoemd. Schadelijke gevolgen van interacties van stoffen met het afweersysteem (immunotoxiciteit) worden van oudsher onderzocht door middel van bestudering van veranderingen in gewicht van relevante organen, histopathologie (microscopische studie van ziekteprocessen) van immunologisch weefsel, en immuunfunctietesten. Analyse van genexpressieprofielen is een relatief nieuwe methode om immunotoxiciteit te bestuderen. Voorbeelden van 'immunotoxicogenomics' studies die verschenen zijn in de wetenschappelijke literatuur (Hoofdstuk 1 en [1]) hebben laten zien dat microarray-analyse in staat is bekende en tot dusver onbekende effecten van een breed scala aan immuunmodulerende verbindingen aan te tonen. Deze studies hebben echter ook aangetoond dat de dosis, blootstellingsduur, en het aantal genen dat wordt onderzocht van grote invloed kunnen zijn op de uitkomst van microarray-analyses. Ook geven ze het belang aan van het koppelen van genexpressiegegevens aan pathologische en functionele eindpunten voor correcte interpretatie van de gegevens. Naast het ophelderen van werkingsmechanismen van toxische agentia kan toxicogenomics ook de respons van biologische systemen op blootstelling aan deze verbindingen voorspellen. Succesvolle pogingen om stoffen te classificeren op basis van genexpressiegegevens die overeenkomen met profielen die specifiek zijn gebleken voor een bepaald effect zijn al gerapporteerd buiten het gebied van de immunotoxicologie. Databestanden waarin genexpressieprofielen behorend bij een biologisch proces of effect zijn opgeslagen, kunnen dergelijke toepassingen van toxicogenomics bevorderen. Methoden en technische details van microarray-analyse kunnen echter variëren, wat het verzamelen en vergelijken van gegevens afkomstig van verschillende laboratoria kan bemoeilijken. Om die reden wordt veel aandacht besteed aan standaardisering van het genereren, rapporteren en beheren van genexpressiedata. Ondanks het feit dat voor het toepassen van toxicogenomics voor bestudering van immunotoxiciteit dus nog hindernissen zullen moeten worden overwonnen, draagt deze onderzoeksmethode al bij aan het begrip van immunotoxische processen en de ontwikkeling van in vitro ('in glas', ofwel buiten het organisme) testmethoden. De verwachting is daarom dat toxicogenomics waardevol zal blijken voor het verkrijgen van inzicht in werkingsmechanismen van imuunmodulerende verbindingen en voor het beoordelen van de schadelijke uitwerking van bestaande stoffen en stoffen met een nog onbekend effect. Deze aannamen werden getoetst in een reeks van experimenten die de bruikbaarheid van genexpressieprofilering voor het identificeren van immunotoxische processen onderzochten. De voornaamste bevindingen van deze studies worden hieronder samengevat. 
De 'Local Lymph Node Assay' (LLNA), die in de muis wordt uitgevoerd, werd oorspronkelijk ontwikkeld om het vermogen van stoffen om een allergische reactie teweeg te brengen te beoordelen. De respons (namelijk verhoogde celdeling ofwel proliferatie) van immuuncellen (lymfocyten) in lymfeklieren na het aanbrengen van een verbinding op de huid is dan een maat voor het vermogen van een stof om allergie te induceren. In Hoofdstuk 2 is een alternatieve toepassing van deze test beschreven. Voordat een aangepaste LLNA met een bekende allergene verbinding werd uitgevoerd, werd aan de muizen de immuunsuppressieve verbindingen bis(tri- $n$-butyltin)oxide (TBTO), cyclosporine A (CsA) of benzo[a]pyreen (B[a]P) toegediend gedurende 28 dagen. De effecten van deze stoffen op de proliferatieve respons van lymfocyten op het allergeen waren nu een maat voor hun effecten op de immuunrespons. Daarnaast werd de uitscheiding van cytokines (eiwitten die een signaal doorgeven en cellulaire processen in gang kunnen zetten) die verband houden met een Th1 of Th2 type immuunrespons gemeten, met als doel inzicht te verkrijgen in effecten van de toegediende agentia op de Th1/Th2 balans. Zowel de proliferatie van lymfekliercellen als de uitscheiding van de cytokines IL-4 en IFN- $\gamma$ werden onderdrukt door alle stoffen, wat wijst op immuunsuppressie. Een vergelijking van de niveaus van beide cytokines liet zien dat TBTO een verschuiving richting Th2- en CsA en $\mathrm{B}[\mathrm{a}] \mathrm{P}$ richting Th1-gemediëerde immuniteit veroorzaakten. Dit zou een weerslag kunnen hebben op ontwikkeling van allergie en autoimmuniteit. Uit deze studie werd geconcludeerd dat de immuunfunctietest afgeleid van de LLNA bruikbaar is voor het aantonen van onderdrukking van de immuunrespons door oraal toegediende agentia, met name bij hoge allergeendoseringen. De resultaten lieten tevens de mate van immuunsuppressie door de verschillende verbindingen zien, wat van belang was voor de experimenten die beschreven zijn in Hoofdstuk 3 en Hoofdstuk 5, waarin dezelfde doseringen als gebruikt in Hoofdstuk 2 toegepast werden.

\section{Aantonen van immunotoxische effecten met behulp van genexpressie-analyse}

On inzicht te krijgen in de potentie van genexpressieprofilering om immunotoxische effecten aan te tonen en mechanistische informatie te genereren, werden veranderingen in transcriptie van genen na blootstelling van muizen aan een immuunsuppressieve dosis TBTO gedurende 3, 7 of 14 dagen bestudeerd in de thymus, het voornaamste doelwit orgaan van deze verbinding. TBTO blootstelling resulteerde in atrofie (afname van weefselmassa) van de thymus, en microarray-analyse gaf een verminderde expressie van genen die coderen voor moleculen en receptoren op het oppervlak van immuuncellen en remming van processen die in verband staan met celdeling aan. Deze resultaten duiden op verstoring van $T$ cel activatie en remming van lymfocytproliferatie als belangrijkste werkingsmechanisme van TBTO. Sommige effecten van TBTO op cellulaire processen die in deze studie gevonden werden (bv. verstoring van eiwit productie) waren al eerder beschreven in de literatuur, andere nog niet. Een voorbeeld van dit laatste was stimulering van processen die in mitochondriën (celcompartimenten verantwoordelijk voor energieproductie) plaatsvinden en van substraatmetabolisme. Dit wijst mogelijk op een adaptieve respons op mitochondriële schade of cellulaire stress. De effecten op 
vetmetabolisme werden mogelijk gemediëerd door diverse kernreceptoren waarvan de expressie veranderde door blootstelling aan TBTO.

Een vergelijkbaar experiment werd uitgevoerd in ratten. Een lagere dosis die desalniettemin thymusatrofie veroorzaakte, resulteerde hier nauwelijks in genexpressieveranderingen in de thymus en de milt. In de lever van de ratten werd remming van vetsynthese gedetecteerd. De verschillen tussen de resultaten van deze studie en die in de muis, beide beschreven in Hoofdstuk 3, werden toegeschreven aan het verschil in toegediende dosis of soort-specifieke effecten.

\section{Aantonen van immunotoxiciteit met behulp van genexpressie-analyse in vitro}

Aangezien er nauwelijks effecten van TBTO op genexpressie werden gevonden in de rattenthymus, werden in het experiment beschreven in Hoofdstuk 4 primaire thymocyten (cellen die rechtstreeks uit de thymus verkregen zijn) direct blootgesteld aan verschillende doseringen van TBTO in vitro. Op deze manier werden verschillende aanwijzingen voor het werkingsmechanisme van TBTO gevonden. Een effect op vetmetabolisme werd gevonden bij een lage dosis die nog geen meetbaar effect op celfunctioneren had, en hogere doseringen leidden tot regulatie van apoptose (geprogrammeerde celdood), zelfs al voordat dit fenotypisch zichtbaar werd. De resultaten suggereerden een mogelijke rol van de glucocorticoïdereceptor in de effecten van TBTO op apoptose. De hoogste dosering die werd bestudeerd, onderdrukte daarnaast het functioneren van mitochondriën en immuuncelactivatie. Verschillende resultaten waren in overeenstemming met eerder gerapporteerde bevindingen, maar in tegenstelling tot de conclusie van Hoofdstuk 3 en van eerdere in vitro en in vivo studies dat remming van celproliferatie het voornaamste werkingsmechanisme van TBTO zou zijn, leek in deze studie met name apoptose het toxische effect van TBTO te mediëren. Deze tegenstrijdigheid komt hoogst waarschijnlijk voort uit verschillen in opzet van de studies (in vitro vs. in vivo, blootstellingsduur).

\section{Overlappende genexpressieprofielen van immunotoxische verbindingen}

Nadat geconstateerd was dat immunotoxische effecten van TBTO zichtbaar konden worden gemaakt door middel van microarray-analyse in het doelwit orgaan (Hoofdstuk 3 en Hoofdstuk 4), was een volgende stap het vinden van gemeenschappelijke effecten van een reeks immuunsuppressieve model verbindingen op gentranscriptie, die uiteindelijk bruikbaar zouden kunnen zijn voor het ontwikkelen van testsystemen voor het identificeren van immunotoxische eigenschappen van stoffen met een nog onbekend effect. In Hoofdstuk 5 wordt beschreven hoe genexpressieprofielen werden bepaald in de milt van muizen die bloot werden gesteld aan TBTO, CsA, B[a]P en paracetamol (APAP). Diverse stof-specifieke en collectieve effecten werden waargenomen. Zo verstoorde TBTO bijvoorbeeld de ademhalingsketen in mitochondriën, en CsA en $\mathrm{B}[\mathrm{a}] \mathrm{P}$ remden verschillende immunologische processen. Alle stoffen induceerden enzymen betrokken bij het metabolisme van xenobiotica. Het meest significant aangetaste proces was voor alle stoffen celdeling (zoals voor TBTO ook in de thymus werd gevonden in Hoofdstuk 3). Snel delende immuuncellen zullen in hoge mate gevoelig zijn voor dit laatste effect, en het 
meten van celproliferatie blijft dus een belangrijke methode om immuunsuppressie aan te tonen.

Paracetamol is geen prototype immuunsuppressieve verbinding, maar omdat eerder onderzoek aanwijzingen opleverde dat paracetamol immuunmodulerende eigenschappen zou kunnen bezitten, werden de effecten van deze stof vergeleken met die van de andere agentia. Blootstelling aan paracetamol leidde tot effecten op gentranscriptie die gedeeltelijk overlap vertoonden met die van de model verbindingen, resulteerde in afname van de grootte van de milt zonder dat effecten op lichaamsgewicht werden waargenomen, en veroorzaakte bovendien een mate van suppressie van de immuunrespons in de immuunfunctietest die afgeleid werd van de LLNA overeenkomstig met de andere stoffen (Hoofdstuk 2). Hierdoor werd geconcludeerd dat paracetamol in de dosering die gebruikt werd in deze studie in staat is het immuunsysteem te onderdrukken en dat dit plaats lijkt te vinden door middel van het stopzetten van de celcyclus.

\section{Bestudering van immuunmodulerende effecten van een probioticum}

Om de effecten van Lactobacillus casei Shirota (LCS) op Th1 type immuunresponsen en het ontstaan van autoimmuunziekten te bevestigen en verder te onderzoeken, werden de immuunmodulerende eigenschappen van dit probioticum (een micro-organisme dat de darmflora van de gastheer verandert en waarvan een gezondheidsbevorderend effect wordt verwacht) onderzocht met behulp van diverse analyses, waaronder genexpressieprofilering als een nieuwe benadering. Hoofdstuk 6 beschrijft de resultaten van deze studies. De aard van de immuunmodulatie door LcS werd bepaald door het experimentele model dat werd gebruikt. In analyses van de respons van lymfocyten op LcS (proliferatie en cytokine uitscheiding) werd geen effect gemeten. LcS remde de Th1gemediëerde immuunrespons in de immuunfunctietest die afgeleid werd van de LLNA, maar verergerde Experimentele Autoimmuun Encephalomyelitis (EAE). Deze wisselende effecten op Th1 responsen wijzen erop dat zowel gunstige als schadelijke effecten op immuun-gerelateerde aandoeningen zouden kunnen optreden na LcS consumptie. Genexpressieprofielen in mesenteriale lymfeklieren, milt, thymus en lever gaven de immunomodulatie door LcS die in de andere analyses werd gedetecteerd niet weer. De reden hiervoor zou kunnen zijn dat de effecten van het probioticum op het immuunsysteem slechts subtiel waren, of, aangezien wel effecten werden gevonden in het autoimmuunmodel, dat $\mathrm{T}$ cel activatie nodig is alvorens LcS immuunmodulatie kan bewerkstelligen. Een andere verklaring kan zijn dat effecten van LcS voornamelijk plaatsvinden op eiwit en niet op genexpressie niveau. 


\section{Discussie}

Het onderzoek dat beschreven is in dit proefschrift was gericht op het aantonen van immunotoxiciteit door middel van genexpressieprofilering. Het effect van alle gebruikte stoffen op immuunfunctie werd bestudeerd met behulp van een immuunfunctietest die werd afgeleid van de LLNA. De bruikbaarheid van deze methode voor het aanduiden van immuunsuppressieve effecten werd in diverse hoofdstukken bewezen.

De microarray-analyses die werden uitgevoerd voor de immuunmodulerende agentia brachten verschillende zaken naar voren die ook in eerdere toxicogenomics studies werden opgemerkt. De invloed van blootstellingsduur op het genexpressieprofiel werd bijvoorbeeld zichtbaar in de in vitro studie, waarin het induceren van apoptose vooraf leek te gaan aan remming van celdeling, het meest prominente effect van TBTO na langdurigere blootstelling in vitro in eerdere studies en in onze eigen in vivo studie. Het effect van de toegediende dosering op microarrayresultaten werd gedemonstreerd in de studies in muis en rat. Toediening van een hoge dosis TBTO aan muizen had significante genexpressieveranderingen tot gevolg, terwijl duidelijke regulatie van genexpressie afwezig was in de thymus van ratten die blootgesteld waren aan een lagere dosis. De indruk dat hoge doseringen vereist zijn om genexpressieprofielen te beïnvloeden, werd ondersteund door de experimenten in de milten van de muizen. Daar resulteerden maximaal tolereerbare doseringen van $\mathrm{CsA}$ en $\mathrm{B}[\mathrm{a}] \mathrm{P}$ niet in significante regulatie van individuele genen. Een analyse waarbij naar groepsgewijze veranderingen van genen binnen een functionele categorie werd gekeken, toonde echter wel regulatie van cellulaire processen die relevant zijn voor het werkingsmechanisme van deze stoffen aan, en is dus een sterk middel om relatief subtiele effecten op genexpressie te detecteren.

De uitkomsten van het beschreven onderzoek ondersteunen de aanname dat microarray-analyse schadelijke effecten kan aantonen bij lagere doseringen dan methoden die van oudsher in de toxicologie worden gebruikt niet. De verschillen tussen de resultaten van de muizen- en rattenstudies zouden theoretisch ook veroorzaakt kunnen worden door soort-specifieke effecten in plaats van of naast verschillen in gebruikte doseringen, maar aangezien enige mate van atrofie van de thymus (een gevoelige indicator voor immunotoxiciteit) wel werd waargenomen in ratten terwijl regulatie van de genexpressie nauwelijks optrad, wijst eerder op een dosis-gerelateerd effect. LcS blootstelling induceerde eveneens geen significante veranderingen van gentranscriptie terwijl modulatie van immuunresponsen wel werd waargenomen met behulp van meer traditionele testmethoden. Aan genexpressieprofilering wordt ook een grotere gevoeligheid ten opzichte van andere analyses met betrekking tot blootstellingsduur toegedicht. Sommige effecten van TBTO, CsA, B[a]P en paracetamol op genexpressie waren inderdaad waarneembaar voordat effecten op orgaangewicht of histologie werden gevonden. In het in vitro experiment was inductie van apoptose door TBTO eerder te observeren op genexpressie niveau dan fenotypisch. Wel werden zowel apoptosisstimulerende als -remmende processen in gang gezet. Veranderingen in expressie van genen die een rol spelen in een bepaald proces hoeven dus niet per definitie allemaal in dezelfde richting te wijzen. Daarnaast worden vaak niet alle genen die onderdeel zijn van een specifieke cellulaire cascade op een zelfde moment gereguleerd. Bovendien kunnen stoffen effecten bewerkstelligen die niet op het niveau van gentranscriptie waarneembaar zijn. Van TBTO is bijvoorbeeld bekend dat het celmembranen, het celskelet en 
eiwitfosforylering aantast, en ook effecten van probiotica op het immuunsysteem zouden met name op eiwit niveau kunnen plaatsvinden. Ten slotte is het ook mogelijk dat probiotica of andere immuunmodulerende agentia pas een uitwerking kunnen hebben op het immuunsysteem wanneer een immuunrespons op gang is gebracht. In dat geval zouden immuunfunctietesten meer geschikt zijn voor het aantonen van immuunmodulerende effecten. Over het algemeen zullen genexpressieprofielen mogelijk niet altijd uitsluitsel kunnen geven over het al dan niet optreden van een (immuno)toxisch effect, maar hebben ze wel de potentie om effecten op een vroeg moment te onthullen.

De interpretatie van resultaten van microarray studies kan bemoeilijkt worden door het effect van veranderingen in celpopulaties op het genexpressieprofiel. Snel delende thymocyten in de cortex van de thymus zijn bijvoorbeeld extra gevoelig voor effecten van TBTO. Op enig moment na aanvang van de blootstelling kan deze celpopulatie met het bijbehorende genexpressieprofiel in vivo uit de thymus verdwenen zijn, terwijl deze cellen in vitro mogelijk minder efficiënt verwijderd kunnen worden. In het in vitro experiment dat is beschreven in dit proefschrift zou de gelijktijdige waarneming van apoptose-stimulerende en -remmende processen verklaard kunnen worden door het optreden van verschillende effecten in verschillende subpopulaties van cellen. Wanneer genexpressie wordt bestudeerd in de milt kan instroom van cellen via het bloed, mogelijk als gevolg van blootstelling aan xenobiotica, van invloed zijn op de bevindingen. Bovendien kunnen verschillende stoffen verschillende celtypen die aanwezig zijn in dit orgaan als doelwit hebben. Bij onderzoek naar werkingsmechanismen is het daarom van belang dat waargenomen genexpressieveranderingen naast effecten die door middel van andere analyses worden waargenomen gelegd worden. Wanneer verbindingen worden gecontroleerd op mogelijke immunotoxische eigenschappen is het echter voornamelijk van belang dat toxische effecten uiteindelijk af te leiden zijn uit het totale genexpressieprofiel. In alle hierboven genoemde gevallen was het mogelijk om effecten van de stoffen te detecteren door middel van microarray-analyse.

Met behulp van toxicogenomics kan de respons van het complete genoom op blootstelling aan xenobiotica in kaart gebracht worden. De verwachting is daarom dat deze onderzoeksmethode uitbreiding van kennis omtrent werkingsmechanismen van toxische stoffen zal opleveren. In dit proefschrift zijn in vivo en in vitro studies beschreven die het werkingsmechanisme van TBTO bestudeerden. Verschillende bekende effecten van TBTO, zoals verstoring van het functioneren van mitochondriën en van eiwitsynthese, werden door microarray-analyse gedetecteerd. Of TBTO hoofdzakelijk celdeling remt of apoptose induceert is een reeds lang bestaand discussiepunt. Terwijl het eerste effect werd waargenomen in de thymus in muizen, was het laatste het voornaamste effect van TBTO in rattenthymocyten in vitro. Hoewel soort-specifieke effecten hier een rol zouden kunnen spelen, werd remming van celproliferatie eerder ook in ratten waargenomen. Het is daarom waarschijnlijk dat het aanzetten van cellen tot apoptose een effect van TBTO is dat voorafgaat aan het stopzetten van de celcyclus. Aanvullende experimenten die effecten in vivo op een vroeger tijdstip en in vitro in muizenthymocyten bestuderen, zijn nodig om deze theorie te kunnen bevestigen. Andere nieuwe mechanistische informatie die aan het licht werd gebracht door de microarray-analyses was bijvoorbeeld de verminderde expressie van oppervlakte moleculen op immuuncellen, de mogelijke rol van de glucocorticoïdereceptor signaleringscascade in effecten van TBTO op apoptose en de regulatie van vetmetabolisme via veranderde expressie van kernreceptoren. Ook deze 
effecten en hun functionele uitwerking zullen moeten worden bevestigd in nieuwe studies. Paracetamol is een andere stof waarvoor de immunotoxicogenomics benadering nieuwe inzichten in werkingsmechanismen opleverde. De aanwijzingen voor immuunsuppressieve eigenschappen van paracetamol die eerder verschenen in de wetenschappelijke literatuur en die voortkwamen uit het bestuderen van de miltgrootte en uit de immuunfunctietest afgeleid van de LLNA, werden ondersteund door de overlap in genexpressieveranderingen door deze stof en de immunotoxische modelstoffen. Omdat het immuunsysteem beschikt over reservecapaciteit en compensatiemechanismen en de mate van verandering in genexpressie niet noodzakelijkerwijs overeen hoeft te komen met een functioneel effect van gelijke grootte, moeten de klinische implicaties van deze bevindingen nog verder onderzocht worden.

Een andere belofte van toxicogenomics is dat het door het genereren van genexpressieprofielen die specifiek zijn voor een bepaalde klasse verbindingen bij zal dragen aan de ontwikkeling van testsystemen voor het voorspellen van effecten van verbindingen. Deze aanname werd onderzocht door genexpressieprofielen van meerdere immunotoxische stoffen te vergelijken. Het stopzetten van de celcyclus (zij het mogelijk via verschillende mechanismen) kwam naar voren als een gemeenschappelijk effect van deze stoffen, en genexpressieveranderingen die als indicator voor immuunsuppressie zouden kunnen gelden ('biomarkers') werden geïdentificeerd. Deze studie illustreert de waarde van het bestuderen van effecten van xenobiotica op celdeling, zoals dat ook gebeurt binnen het huidige immunotoxiciteitsonderzoek. Uiteraard zal een grotere reeks verbindingen getest moeten worden om de specificiteit en voorspellende waarde van remming van celproliferatie voor immunotoxiciteit in het algemeen vast te stellen. De onderzoeksgroep van Patterson [2] heeft genexpressieveranderingen in de thymus van muizen blootgesteld aan de immuunsuppressieve modelstoffen CsA, 2,3,7,8tetrachloordibenzo-p-dioxine (TCDD), cyclofosfamide, en dexamethason bestudeerd. Voorlopige analyses lieten zien dat hoewel de meeste genexpressieveranderingen stofspecifiek waren, sommige genen door alle stoffen gereguleerd werden. Deze genen speelden met name een rol in apoptose, antigeenpresentatie en -verwerking, en immuuncelactivatie en -proliferatie. De genen vertonen geen overlap met de genen die geïdentificeerd werden in de hierboven beschreven studie; een reden hiervoor kan zijn dat de gebruikte microarrays een gelimiteerd aantal genen bevatten en dat slechts een deel van de bevindingen tot op heden is gepubliceerd [2]. Aangezien beide studies zich beperkten tot immuunsuppressieve stoffen, zal de bruikbaarheid van het onderzoeken van effecten op celdeling binnen andere gebieden van de immunotoxicologie (zoals sensibilisatie en autoimmuniteit) nog uitgezocht moeten worden. De studie beschreven in Hoofdstuk 5 toonde eveneens aan dat de milt een geschikt orgaan is voor het aantonen van onderdrukking van het immuunsysteem middels genexpressieprofilering. Omdat het aannemelijk is dat effecten in dit orgaan weerspiegeld zullen worden in perifere lymfocyten, die relatief gemakkelijk uit bloed verkregen kunnen worden, is dit een waardevolle bevinding voor wat betreft het ontwikkelen van testmethoden. Toekomstige analyses van genexpressieprofielen in humane cellen zal de relevantie van de bevindingen voor de humane situatie moeten uitwijzen. Aangezien effecten van xenobiotica die worden waargenomen in vitro kunnen verschillen van effecten in vivo, en in vitro testmethoden vaak niet de diversiteit aan celtypen die een rol spelen in het immuunsysteem vertegenwoordigen, zal echter eerst de relevantie van in vitro verkregen 
resultaten voor de in vivo situatie en de mogelijkheid om met behulp van in vitro methoden immunotoxische effecten te voorspellen verder onderzocht moeten worden.

Verschillende zaken die hierboven aan bod zijn gekomen werden ook bediscussieerd in een workshop omtrent de toepassing van toxicogenomics voor het opsporen van immunotoxische effecten van xenobiotica en in een recent overzichtsartikel over dit onderwerp [1,3].

\section{Conclusie}

Uit de resultaten die gepresenteerd worden in dit proefschrift kan geconcludeerd worden dat voor het onderzoeken van immunotoxische effecten van verbindingen door middel van bestudering van genexpressieprofielen meerdere doseringen en blootstellingsperiodes nodig zijn. Immunotoxicogenomics lijkt niet gevoeliger dan traditionele methoden om immunotoxiciteit te bestuderen voor wat betreft de doseringen die nodig zijn om effecten aan het licht te brengen, maar maakt wel het aantonen van onderdrukking van het immuunsysteem kort na aanvang van de blootstelling mogelijk. Remming van celproliferatie kwam naar voren als een gemeenschappelijk effect van een serie immuunsuppressieve modelverbindingen. Aangezien een breder scala aan stoffen onderzocht moet worden en in vitro testsystemen voor het beoordelen van effecten van xenobiotica verder verfijnd moeten worden, zal toxicogenomics op dit moment de huidige methoden voor het bestuderen van immunotoxiciteit nog niet kunnen vervangen. Het is echter een waardevol middel om inzicht in werkingsmechanismen uit te breiden en biedt mogelijkheden voor het identificeren van ongewenst effecten van stoffen met nog (gedeeltelijk) onbekende effecten.

\section{Referenties}

1. Burns-Naas, L.A., Dearman, R.J., Germolec, D.R., Kaminski, N.E., Kimber, I., Ladics, G.S., Luebke, R.W., Pfau, J.C., Pruett, S.B. (2006) 'Omics' technologies and the immune system. Tox Mech Methods 16, 101119.

2. Patterson, R.M., Germolec, D.R. (2006) Gene expression alterations in immune system pathways following exposure to immunosuppressive chemicals. Ann N Y Acad Sci 1076, 718-727.

3. Luebke, R.W., Holsapple, M.P., Ladics, G.S., Luster, M.I., Selgrade, M., Smialowicz, R.J., Woolhiser, M.R., Germolec, D.R. (2006) Immunotoxicogenomics: the potential of genomics technology in the immunotoxicity risk assessment process. Toxicol Sci 94, 22-27. 

Dankwoord 
Na ruim 4 jaar onderzoek en meer dan 150.000 kilometer ligt het er dan, het proefschrift dat niet alleen het eindpunt van het promotie traject maar ook de afsluiting van een leerzame, soms vermoeiende, maar vooral toch ook leuke periode is. Aan het eind van de rit ben ik een groot aantal mensen dank verschuldigd.

Allereerst Henk: ik heb veel bewondering voor jouw kennis en kunde en heb daar veel van kunnen leren. Fijn dat je ondanks je drukke agenda altijd tijd voor me kon maken. De wijze waarop jij steeds zo goed het overzicht en grotere geheel kon zien en verwoorden, je positieve blik (waaraan het mij nog wel eens ontbrak) en je overtuiging waren voor mij erg motiverend en hebben me steeds een stapje verder gebracht. Bedankt hiervoor, voor je vertrouwen in mij, en voor de plezierige samenwerking die we gelukkig nog hebben kunnen voortzetten!

Jeroen, ook aan jou heb ik enorm veel te danken, want zonder jouw hulp, je schat aan bioinformatica-kennis en de supersnelle analyses had ik alle microarray data nooit zo vlot kunnen uitwerken en publiceren. Ook tijdens de laatste schrijffase heeft jouw bijdrage me erg geholpen. Een meer dan verdiende plaats voor jou als co-promotor dus!

Jos, dank voor de kans om onderzoekservaring te kunnen opdoen aan de UM, zowel tijdens mijn promotie onderzoek als binnen het huidige project.

Janine, jij was voor het probiotica project én voor mij een welkome aanvulling op de afdeling. Ook buiten Hoofdstuk 6 heb je me vaak vooruit kunnen helpen, en los van het werk heb ik het erg gezellig met je gehad. Heel jammer dat je er 15 november niet bij kunt zijn, maar wát een goed excuus!!!

Rob, ook al verschoven jouw werkzaamheden wat uit de genomics hoek, fijn dat je toch altijd interesse bent blijven houden in mijn bezigheden en dankjewel voor alle nuttige info en feedback! En leuk dat we nu toch weer kunnen samenwerken.

Eerst bij LPI en later bij TOX was het medeleven en de geweldige hulpvaardigheid van iedereen steeds een enorme steun in de rug. Met name Arja: altijd bereid om bij te staan met lab werk, maar ook op persoonlijk vlak enorm betrokken en attent. Dankjewel daarvoor! En Eric, jouw hulp bij onder andere het RNA isoleren en de arrays zorgde niet alleen voor een goede productiviteit maar had ook steevast een hoog gehalte aan creativiteit, vindingrijkheid en verfrissende fantasie en humor. Dat kon ik erg waarderen! Peter, jouw enthousiasme voor en loopbaan binnen de wetenschap bewonderde ik zeer, evenals de betrokkenheid bij je collega's en studenten en zo ook bij mijn promoveren. Maar ook Wim, Henny V. (zeker ook de afgelopen maanden!), Bert, Liset, Yvonne en Jolanda $\mathrm{V}$.: bedankt voor jullie hulp waar nodig en dat ik me nooit bezwaard hoefde te voelen om bij jullie aan te kloppen.

Harry en Annemieke, Timo en Martijs: bedankt voor het meedraaien in jullie CEFIC project, ik ben blij dat we van de milt data een mooie publicatie hebben kunnen maken. Mirjam, Femke, Rebecca en Tessa: jullie werk heeft mij een hoop uren bespaard, bedankt daarvoor! Femke, leuk dat ons LLNA artikel de eerste publicatie voor dit proefschrift werd en Mirjam, dankjewel voor alle keren dat ik aan je bureau stond met een vraag, voor al je hulp, en dat je je RNA expertise met me hebt willen delen. Anja en Annemarie bedankt voor de introductie in de wereld van de microarrays, en Joost voor een vliegende start met de real time PCR. Verder veel dank aan Coen voor alle secties, evenals Hans (ook voor het regelen van alle thymussen!), Piet en Christine. Cor, Ruud en Paul bedankt voor het huisvesten van de muizen. Mirjam L., fijn dat ik je paracetamol materiaal mocht gebruiken, 
voor mij nog erg nuttig (net als jouw pionierswerk voor de real time trouwens). Ook Bianca, Christiaan en Marloes bedankt voor jullie hulp op het lab. Joanna, your Dutch adventure allowed you to learn more about microarrays and me about TBTO, which finally resulted in Chapter 4. Thanks for your dedication to the last experiments to complete my thesis, and for your pleasant company! Dorien en Ilse, jullie werden niet tijdens de gezelligste fase van m'n project voor korte tijd mijn kamergenoot, maar fijn dat jullie me rustig hebben laten typen en voor welkome pauze-praatjes zorgden. Selva: beiden 'Maastrichtse' AiO en treinreiziger, stads- en kamergenoot, maar alles helaas slechts van korte duur. Ik ga nog wat moois maken van het sensibilisatie project!

Als 'Maastrichtse' AiO bleef ik uiteindelijk bij het RIVM hangen (Antoon, bedankt dat ik al die tijd als gast op jouw lab heb mogen werken), maar de weinige keren dat ik bij GRAT was heb ik me daar wel steeds heel welkom gevoeld, en nu ben ik er dan alsnog terecht gekomen. Yvonne en Danitsja, jullie zag ik in het begin nog wel eens op een POT cursus, en aan het eind heb ik dankbaar gebruik mogen maken van jullie proefschrift en promotie ervaringen. Marie-Claire bedankt voor het uitvoeren van al m'n klusjes en verzoekjes, voor lange tijd over de mail.

Hierbij ook een woord van dank aan alle vrienden, bekenden en familieleden die de afgelopen jaren met me mee hebben geleefd (híer ging het dus allemaal om..). En juist ook voor alle o zo noodzakelijke en minstens even waardevolle gezelligheid, het leven bestaat nou eenmaal uit veel meer dan werk alleen!

Tilja, ineens was ik vorig jaar niet meer de enige die voor de Dr. titel ging! Jouw luisterende oor, interesse, begrip en oprechtheid hebben mij steeds erg goed gedaan, en ik ben blij dat jij me straks ook letterlijk bij zult staan!

Lonneke, wie had dit boekje nou beter van een kaft kunnen voorzien dan jij?! En omdat je zo graag bosnimf wilde worden straks ook nog een plek op het erepodium. Fijn om iemand te hebben die me zo goed kent, en ook nog eens geweldig kan relativeren. Reken maar dat ik nu ik weer meer tijd heb wat vaker even de grens over kom voor een biertje of wijntje met jou en Cris!

Lieve C en G, wat is het toch goed om te weten dat jullie hoe dan ook trots op me zijn en altijd vierkant achter me staan. Jullie waren ook nu weer geweldige supporters! Mam, ik wil je bedanken voor je aandacht en je geduld. Ik bof maar met een moeder die zoveel toewijding aan anderen kan geven. En heb je niet altijd al gezegd dat ik nog eens een boek zou schrijven? Pap, bedankt voor alles wat je me van kleins af aan hebt bijgebracht en al je medeleven (o.a. met de NS-perikelen..). Fijn dat jullie er altijd voor me zijn!

En last but zeker not least: lieve Tom, mijn allergrootste steun en toeverlaat, je weet nog niet half hoe belangrijk jouw eindeloze begrip, medelevende aanmoedigingen, en niet te vergeten alle heerlijke maaltjes die je jarenlang voor me klaar had staan, geweest zijn om dit alles te kunnen voltooien. Ik kan bij niemand zo goed mijn hart luchten als bij jou en vind het bewonderenswaardig dat dat je nooit teveel wordt. Bedankt dat ik altijd op je kan rekenen. Veel van mijn tijd en energie zijn de laatste jaren in de aanloop naar dit boekje gaan zitten, de hoogste tijd dus nu om een en ander ruimschoots in te gaan halen. Wij zijn twee vriendjes, jij en ik! 

Curriculum Vitae 

Kirsten Annika Baken werd op 26 september 1980 geboren te Eindhoven. In 1998 behaalde zij het Gymnasium diploma aan het Rythovius College te Eersel. Aansluitend studeerde zij Gezondheidswetenschappen aan de Universiteit Maastricht, met als afstudeerrichting Biologische Gezondheidkunde. Haar afstudeerstage vond plaats bij de afdeling Samengestelde Producten van de Keuringsdienst van Waren (tegenwoordig Voedsel en Waren Autoriteit, VWA) te 's Hertogenbosch, waarna in 2002 het doctoraal diploma werd behaald. Van januari 2003 tot december 2006 was Kirsten aangesteld als assistent in opleiding bij de capaciteitsgroep Gezondheid Risico Analyse en Toxicologie (GRAT) aan de Universiteit Maastricht. Haar promotie onderzoek, dat is beschreven in dit proefschrift, betrof een samenwerking met de afdeling Toxicologie, Pathologie en Genetica (TOX) van het Rijksinstituut voor Volksgezondheid en Milieu (RIVM) te Bilthoven, alwaar het onderzoek is uitgevoerd. Tijdens deze aanstelling werden de certificaten 'Stralingshygiëne, deskundigheidsniveau 5b' en 'Proefdierkunde op grond van art. 9 van de Wet op de Dierproeven' behaald, en werd de Postdoctorale Opleiding Toxicologie gevolgd ten behoeve van registratie als toxicoloog bij de Nederlandse Vereniging voor Toxicologie (NVT). Sinds januari 2007 is Kirsten werkzaam als postdoc bij de capaciteitsgroep GRAT aan de Universiteit Maastricht.

Kirsten Annika Baken was born on September $26^{\text {th }} 1980$ in Eindhoven. She graduated from her secondary education at the Rythovius College in Eersel in 1998. In the same year, she started studying Health Sciences at Maastricht University, with Biological Health Sciences as a sub specialism. After an internship at the Food and Consumer Product Safety Authority (VWA) in 's Hertogenbosch, she received her masters degree in 2002. From January 2003 until December 2006 she has been a PhD student at the department of Health Risk Analysis and Toxicology (GRAT) at Maastricht University. The research conducted in these years and presented in this thesis occurred within a cooperation with the Laboratory for Toxicology, Pathology and Genetics (TOX) at the National Institute for Public Health and the Environment (RIVM) in Bilthoven, at which the actual research activities took place. During this research period, Kirsten obtained licenses for working with laboratory animals (according to art. 9 of the Dutch law on experimental animals) and with radioactive material (level of competence $5 \mathrm{~b}$, as accredited by the Dutch government). In addition, a Postgraduate Education in Toxicology was completed which will result in the registration as a toxicologist within the Netherlands Society of Toxicology (NVT). From January 2007 onward, Kirsten has been working as a postdoctoral fellow at the GRAT department at Maastricht University. 

Jist of publications 


\section{Full papers}

Van den Berg, F.A., Baken, K.A., Vermeulen, J.P., Gremmer, E.R., Van Steeg, H., Van Loveren, H. (2005) Use of the local lymph node assay in assessment of immune function. Toxicology 211, 107-114.

Baken, K.A., Ezendam, J., Gremmer, E.R., De Klerk, A., Pennings, J.L.A., Matthee, B., Peijnenburg, A.A.C.M., Van Loveren, H. (2006) Evaluation of immunomodulation by Lactobacillus casei Shirota: immune function, autoimmunity and gene expression. International Journal of Food Microbiology 112, 8-18.

Baken, K.A., Pennings, J.L.A., De Vries, A., Breit, T.M., Van Steeg, H., Van Loveren, H. (2006) Gene expression profiling of bis(tri- $n$-butyltin)oxide (TBTO) induced immunotoxicity in mice and rats. Journal of Immunotoxicology 3, 227-244.

Baken, K.A., Vandebriel, R.J., Pennings, J.L.A., Kleinjans, J.C., Van Loveren, H. (2007) Toxicogenomics in the assessment of immunotoxicity. Methods 41, 132-141.

Baken, K.A., Arkusz, J., Pennings, J.L.A., Vandebriel, R.J., Van Loveren, H. (2007) In vitro immunotoxicity of bis(tri- $n$-butyltin)oxide (TBTO) studied by toxicogenomics. Toxicology 237, 35-48.

Baken, K.A., Pennings, J.L.A., Jonker, M.J., Schaap, M.M., De Vries, A., Van Steeg, H., Breit, T.M., Van Loveren, H. (2007) Overlapping gene expression profiles of model compounds provide opportunities for immunotoxicity screening. Toxicology and Applied Pharmacology (in press).

\section{Report}

Ezendam, J., Baken, K.A., Van Loveren, H. (2006) Immune effects of Lactobacillus casei Shirota. RIVM report 340320004/2006.

\section{Book chapter}

Baken, K.A., Ezendam, J., Pennings, J.L.A., Vandebriel, R.J., Van Loveren, H. (2007) Toxicogenomics as a tool to assess immunotoxicity. In: Toxicogenomics: a powerful tool for toxicity testing (Sahu SC Ed.), in press. John Wiley \& Sons Ltd., Chichester, UK. 


\section{Abstracts}

Baken, K.A., Pennings, J.L.A., Van Steeg, H., Van Loveren, H. Use of the Local Lymph Node Assay to determine modulation of immune function. $2^{\text {nd }}$ Research in Progress Meeting of the EUROTOX Immunotoxicology and Chemical Allergy Speciality Section (ITCASS), Manchester, UK, November 2004.

Baken, K.A., Pennings, J.L.A., Van Steeg, H., Van Loveren, H. Effects of TBTO and APAP on gene expression in rats and mice. $1^{\text {st }}$ Work in Progress Meeting of the Netherlands Toxicogenomics Centre (NTC), Maastricht, The Netherlands, April 2005.

Baken, K.A., Pennings, J.L.A., Van Steeg, H., Van Loveren, H. Effects of bis(tri-nbutyltin)oxide (TBTO) exposure on gene expression in mice and rats. Annual PhD student meeting of the Netherlands Society of Toxicology (NVT), Oss, The Netherlands, June 2005.

Baken, K.A., Pennings, J.L.A., Van Steeg, H., Van Loveren, H. Microarray analysis of bis(tri-n-butyltin)oxide (TBTO) induced immunotoxicity. Annual Meeting of the Dutch Society for Immunology (NVVI), Noorwijkerhout, The Netherlands, December 2005.

Baken, K.A., Pennings, J.L.A., Van Steeg, H., Van Loveren, H. Microarray analysis of bis(tri-n-butyltin)oxide (TBTO) induced immunotoxicity. $2^{\text {nd }}$ Work in Progress Meeting of the Netherlands Toxicogenomics Centre (NTC), Wageningen, The Netherlands, December 2005.

Baken, K.A., Pennings, J.L.A., Van Steeg, H., Van Loveren, H. Microarray analysis of bis(tri-n-butyltin)oxide (TBTO) induced immunotoxicity. $45^{\text {th }}$ Annual Meeting of the Society of Toxicology (SOT), San Diego, USA, March 2006.

Baken, K.A., Pennings, J.L.A., Van Steeg, H., Van Loveren, H. Use of microarray technology to study the effects of acetaminophen and known immunosuppressants on the immune system. $3^{\text {rd }}$ Research in Progress Meeting of the EUROTOX Immunotoxicology and Chemical Allergy Speciality Section (ITCASS), Lodi, Italy, September 2006.

Baken, K.A., Pennings, J.L.A., De Vries, A., Breit, T.M., Van Steeg, H., Van Loveren, H. Gene expression profiling of bis(tri- $n$-butyltin)oxide (TBTO) induced immunotoxicity in mice and rats. Experimental Animal Alternatives Conference of the Netherlands Vaccin Institute (NVI), Bilthoven, The Netherlands, October 2006.

Baken, K.A., Pennings, J.L.A., Van Steeg, H., Van Loveren, H. Microarray analysis of bis(tri- $n$-butyltin)oxide (TBTO) induced immunotoxicity. International Congress of Immunogenomics and Immunomics, Budapest, Hungary, October 2006.

Baken, K.A., Pennings, J.L.A., Van Steeg, H., Van Loveren, H. Immunotoxicogenomics of TBTO in vivo and in vitro. $4^{\text {th }}$ Work in Progress Meeting of the Netherlands Toxicogenomics Centre (NTC), Leiden, The Netherlands, November 2006. 


